Andrews University

Digital Commons @ Andrews University

1992

\title{
The Use of ns' in the Pentateuch and its Contribution to the Concept of Forgiveness
}

Gudmundur Olafsson

Andrews University

Follow this and additional works at: https://digitalcommons.andrews.edu/dissertations

Part of the Biblical Studies Commons

\section{Recommended Citation}

Olafsson, Gudmundur, "The Use of nś' in the Pentateuch and its Contribution to the Concept of Forgiveness" (1992). Dissertations. 115.

https://digitalcommons.andrews.edu/dissertations/115

https://dx.doi.org/10.32597/dissertations/115

This Dissertation is brought to you for free and open access by the Graduate Research at Digital Commons @ Andrews University. It has been accepted for inclusion in Dissertations by an authorized administrator of Digital Commons@ Andrews University. For more information, please contact repository@andrews.edu. 


\section{Andrews \$university}

Seek Knowledge. Affirm Faith. Change the World.

Thank you for your interest in the

\section{Andrews University Digital Library of Dissertations and Theses.}

Please honor the copyright of this document by not duplicating or distributing additional copies in any form without the author's express written permission. Thanks for your cooperation. 


\section{INFORMATION TO USERS}

This manuscript has been reproduced from the microfilm master. UMI films the text directly from the original or copy submitted. Thus, some thesis and dissertation copies are in typewriter face, while others may be from any type of computer printer.

The quality of this reproduction is dependent upon the quality of the copy submitted. Broken or indistinct print, colored or poor quality illustrations and photographs, print bleedthrough, substandard margins, and improper alignment can adversely affect reproduction.

In the unlikely event that the author did not send UMI a complete manuscript and there are missing pages, these will be noted. Also, if unauthorized copyright material had to be removed, a note will indicate the deletion.

Oversize materials (e.g., maps, drawings, charts) are reproduced by sectioning the original, beginning at the upper left-hand corner and continuing from left to right in equal sections with small overlaps. Each original is also photographed in one exposure and is included in reduced form at the back of the book.

Photographs included in the original manuscript have been reproduced xerographically in this copy. Higher quality $6^{\prime \prime} \times 9^{\prime \prime}$ black and white photogia hic prints are available for any photographs or illustrations appearing in this copy for an additional charge. Contact UMI directly to order.

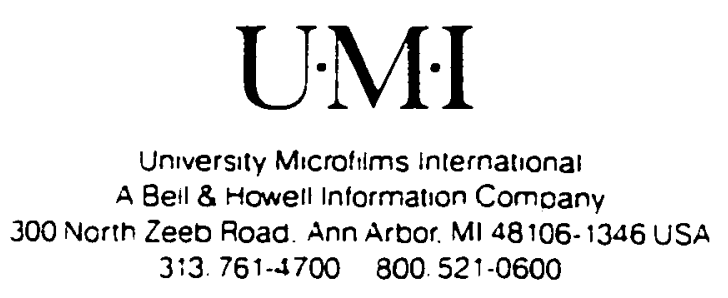


Order Number 9834300

The use of $n s^{\supset}$ in the Pentateuch and its contribution to the concept of forgiveness

Olafsson, Gudmundur, Ph.D.

Andrews University, 1993

Copyright (C)1992 by Olafsson, Gudmundur. All rights reserved.

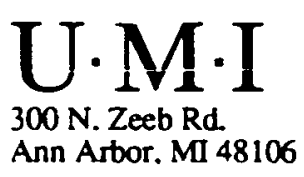




\title{
Ancrews University \\ Seventh-day Adventist Theological Seminary
}

\section{THE USE OF NS' ${ }^{\supset}$ IN THE PENTATEUCH \\ AND ITS CONTRIBUTION TO THE \\ CONCEPT OF FORGIVENESS}

\author{
A Dissertation \\ Presented in Partial Fulfillment \\ of the Requirements for the Degree \\ Doctor of Philosophy
}

by

Gudmundur olafsson

December, 1992 
- Copyright by Gudmundur Olafsson 1992

All Rights Reserved

Reproduced with permission of the copyright owner. Further reproduction prohibited without permission. 


\section{THE USE OF NS ${ }^{\supset}$ IN THE PENTATEUCH \\ AND ITS CONTRIBUTION TO THE CONCEPT OF FORGIVENESS}

A dissertation

presented in partial fulfillment

of the requirements for the degree

Doctor of Philosophy

by

Gudmundur Olafsson

APPROVAL BY THE COMMITTEE:

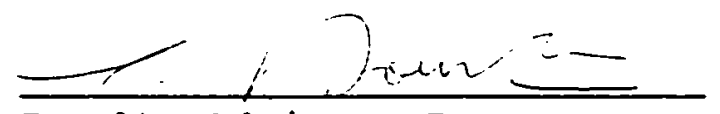

Faculty Advisor: Jacques Doukhan, Professor of old Testament Interpretation

Kichad jil. Daiulum

Richard Davidson, Professor

of old Testament Exegesis

Wiekin A. Stlea.

William H. Shea, Adjunct

Professor of Archeology and

History of Antiquity

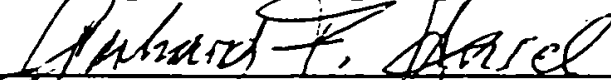

Gephard F. Hasel, Professor of

oda Testament and Biblical

Theology

Sund lialcte

Bruce Waltke, Professor of

old Testament, Regent College

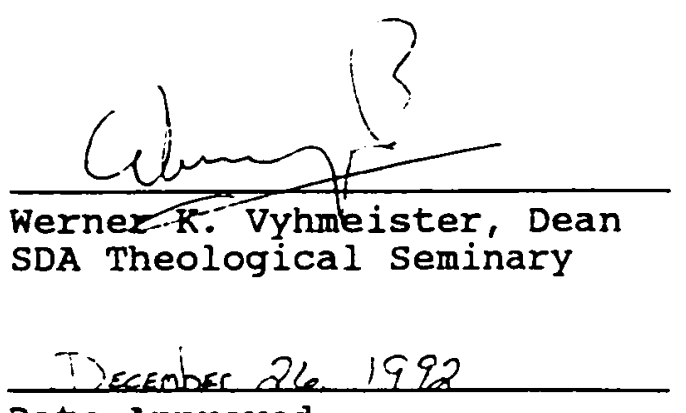

Date Approved 
TABLE OF CONTENTS

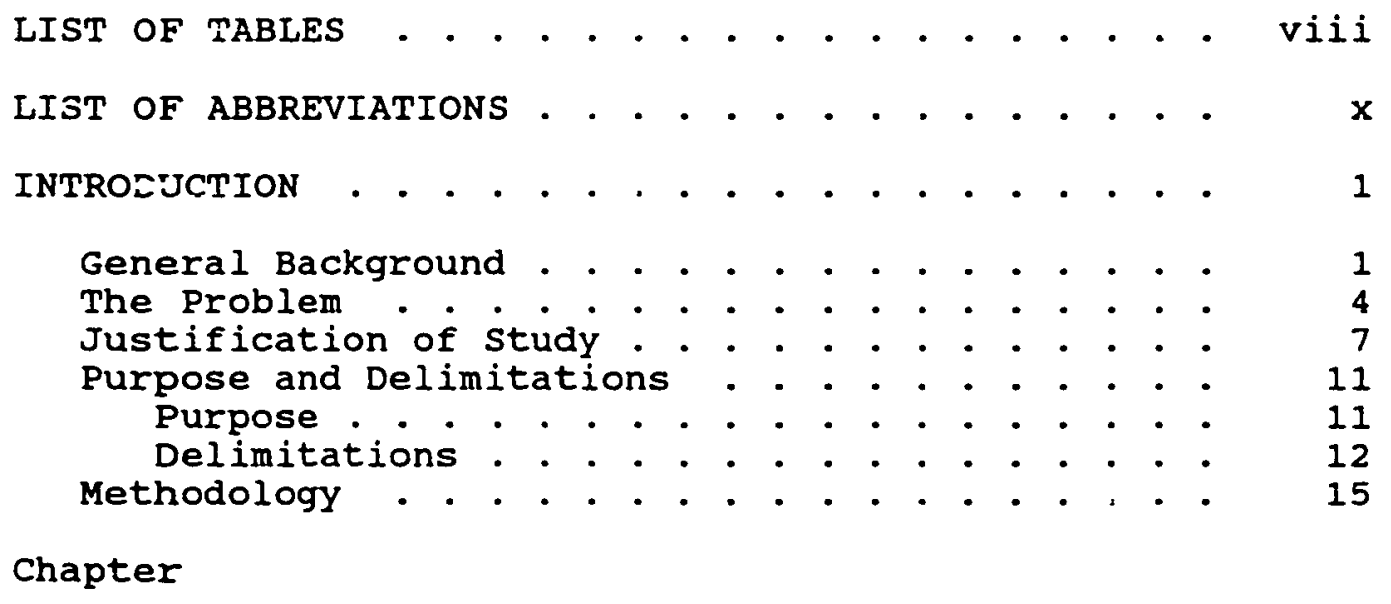

I. SURVEY OF EARLIER STUDIES . . . . . . . . . . 19

Lexical Listings. . . . . . . . . . . 20

G. Gesenius . . . . . . . . . . . . . . 21

General Scope .. . . . . . . . . 21

Specific Meanings . . . . . . . . . . 22

J. Fuerst. . . . . . . . . . . . . . . 24

General Scope . . . . . . . . . . 24

Specific Meanings . . . . . . . . . 25

F. Brown, S. R. Driver, and C. A. Briggs 27

General Srope . . . . . . . . . . 27

Specific Meanings . . . . . . . . . . 28

L. Koehler and W. Baumgartner . . . . . . 29

General Scope ..... . . . . . . 29

Specific Meanings . . . . . . . . . 30

W. L. Holladay . . . . . . . . . . . . . 32

General Scope . . . . . . . . . . 32

Specific Meanings . . . . . . . . . 32

Summary . . . . . . . . . . . . . . . . 34

Basic Meaning . . . . . . . . . . . 36

Semantic-Theological Studies... . . . . 36

F. Stolz . . . . . . . . . . . . . . 37

D. N. Freedman and B. E. Willoughby . . . 39

J. J. Stamm . . . . . . . . . . . . 4 I

R. Knierim . . . . . . . . . . . . . . . 44

พ. 2 immerli... . . . . . . . . . 47

\section{iii}


R. N. Whybray . . . . . . . . . . . 49

Summary . . . . . . . . . . . . . . . 51

II. SURVEY OF EXTRA-BIBLICAL USAGE . . . . . . . 54

Akkadian . . . . . . . . . . . . . . 56

Naša as Transport . . . . . . . . . . . 57

Data . . . . . . . . . . . . . . 57

Comments . . . . . . . . . . . 58

Naša as Support............ . 59

Data . . . . . . . . . . . . . . . 59

Comments . . . . . . . . . . . . $\epsilon 1$

Našl as Utilization... . . . . . . . 62

Data................... 63

Comments . . . . . . . . . . . . . . 63

Naš and Interpersonal Relations . . . . 64

Data... . . . . . . . . . . . 64

Comments............... . 66

Ugaritic . . . . . . . . . . . . . . . 67

$N$ Ša as Transport . . . . . . . . . . 68

Data . . . . . . . . . . . . . 68

Comments................ . . 69

Nša as Support . . . . . . . . . . . 70

Data . . . . . . . . . . . . . 70

Comments . . . . . . . . . . . . . 70

Nša as Utilization . . . . . . . . . 71

Data . . . . . . . . . . . . . 71

Comments . . . . . . . . . . . . 72

Aramaic . . . . . . . . . . . . . . . . 72

$N^{e} \bar{s} \bar{a}$ as Transport . . . . . . . . . . 73

Data............ . . . . . . 73

Comments . . . . . . . . . . . . . . . 74

$N^{e} \bar{s}^{2}$ as Support . . . . . . . . . . . 74

Data... . . . . . . . . . . . . 74

Comments . . . . . . . . . . . . 75

$N^{e} \bar{s}^{J}$ as Utilization .......... . . . 76

Data . . . . . . . . . . . . 76

Comments . . . . . . . . . . . . . 76

$N^{e} \mathbf{s a}^{\supset}$ and Interpersonal Relations . . . . 77

Data . . . . . . . . . . . . 77

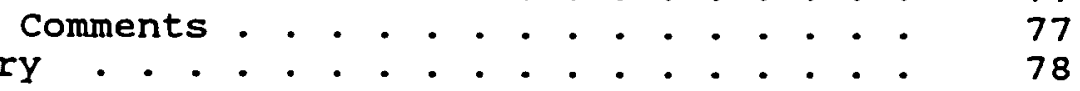

III. SURVEY OF BIBLICAL USAGE . . . . . . . . . . 79

The old Testament in General . . . . . . 79

Introduction . . . . . . . . . . . . . . 79

Distribution and Usage ........ . 82

General . . . . . . . . . . . . . 82

Nominal Forms . . . . . . . . . . . . 83

Verbal Forms . . . . . . . . . . . 91

iv 


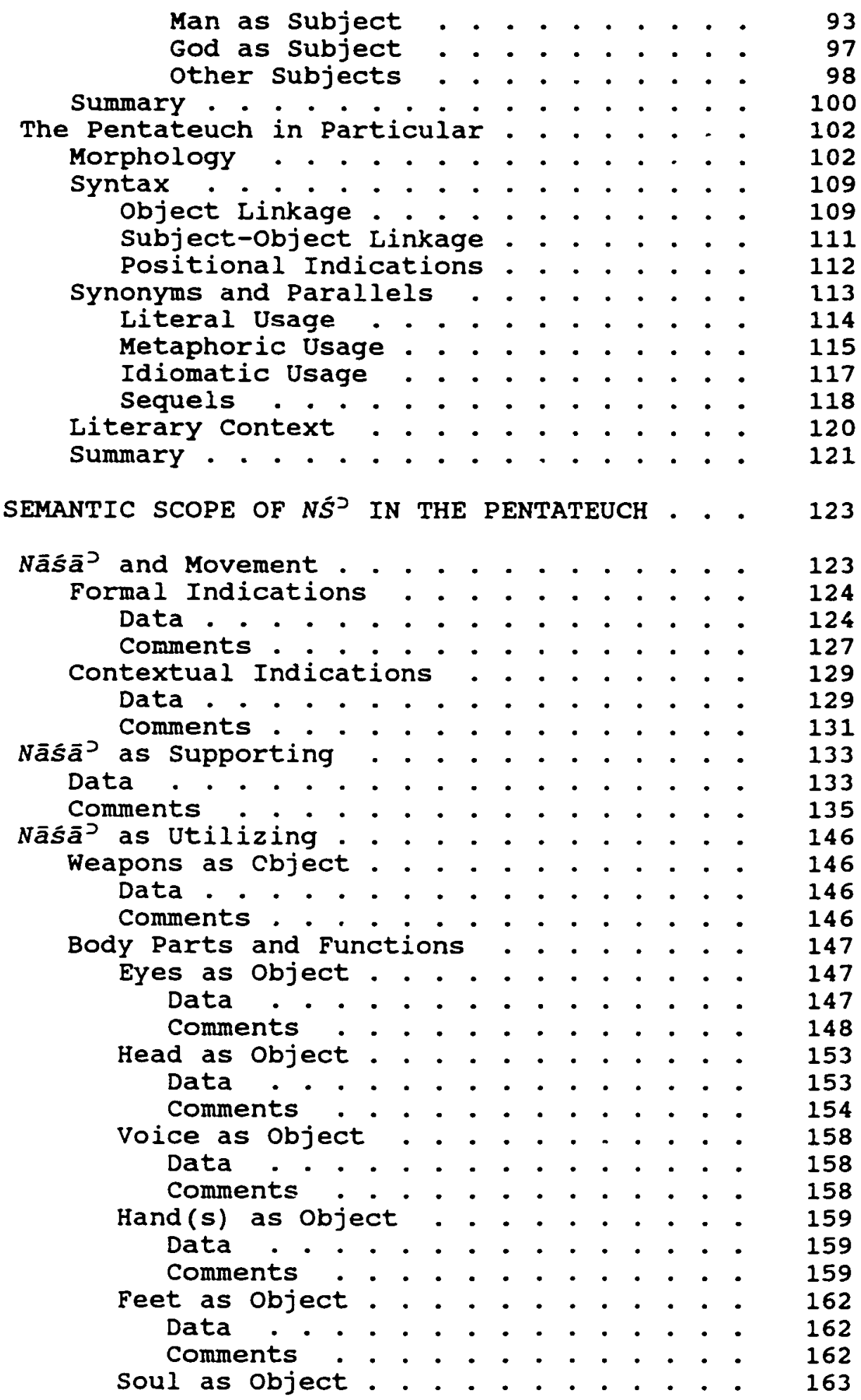

v 


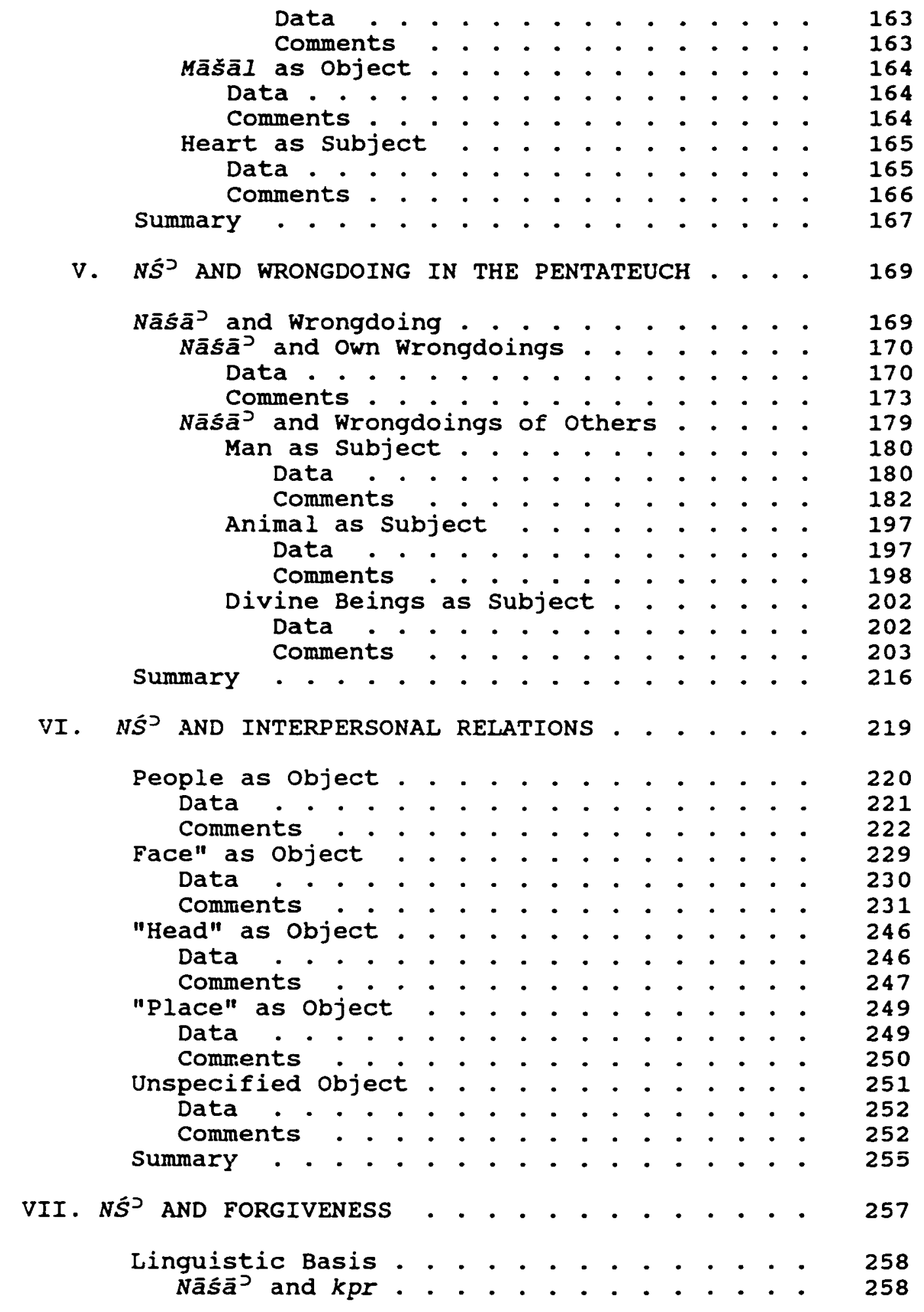

vi 


\begin{tabular}{|c|c|c|c|c|c|c|c|c|c|c|c|c|c|}
\hline & $\begin{array}{l}N \\
\text { heo } \\
\text { Soci } \\
\text { God } \\
\text { Othe } \\
\text { Summ }\end{array}$ & $\begin{array}{l}\bar{a} \mathbf{a} \bar{l}^{2} \text { and sāla } \\
\text { logical conte } \\
\text { al Context. } \\
\text { as Forgiver } \\
\text { r parallels } \\
\text { ary } . .\end{array}$ & : & & 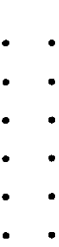 & $\begin{array}{l}\cdot \\
\cdot \\
\cdot \\
\cdot\end{array}$ & 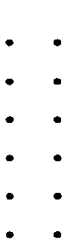 & 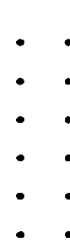 & $\begin{array}{l}\dot{ } \\
\dot{.}\end{array}$ & - & • & & $\begin{array}{l}264 \\
269 \\
275 \\
279 \\
281 \\
287\end{array}$ \\
\hline UMMARY & AND & CONCLUSION & - & & - $\cdot$ & - & - & - & • & - & & - & 290 \\
\hline PPENDI & CES & . . . . . . & • & & & - & - . & - & 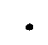 & & & 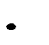 & 308 \\
\hline $\begin{array}{l}\text { A. } \\
\text { B. } \\
\text { C. } \\
\text { D. }\end{array}$ & $\begin{array}{l}\text { Gene } \\
\text { Lite } \\
\text { Pent } \\
\text { "Lif }\end{array}$ & $\begin{array}{l}\text { ral Distribut } \\
\text { rary Context } \\
\text { ateuchal Usag } \\
\text { ting the Head }\end{array}$ & $\begin{array}{l}\text { io } \\
\dot{e} \\
\text { i" }\end{array}$ & & of & $\begin{array}{c}N S^{2} \\
\cdot \\
\cdot\end{array}$ & $\begin{array}{l}\text { in } \\
. \\
.\end{array}$ & $\begin{array}{l}\text { the } \\
\dot{\cdot} \cdot \\
\cdot\end{array}$ & $\begin{array}{l}\mathrm{O}^{\prime} \\
\cdot\end{array}$ & 1 & & $\dot{\bullet}$ & $\begin{array}{l}309 \\
310 \\
311 \\
313\end{array}$ \\
\hline IF & RAPH & - & • & & : & - & - & $\bullet^{\circ}$ & • & $\cdot$ & & & 314 \\
\hline
\end{tabular}

vii 
1. Meanings of $N a \bar{s} \bar{a}^{2}$. . . . . . . . . . 35

2. Distribution of the Root NŚ in the OT . . . 83

3. Distribution of Nominal Forms of $N \hat{s}^{2}$. . . . . 84

4. Distribution of Verbal Root $N \hat{s}^{3}$. . . . . . . 92

5. Distribution of Verbal Aspects in the OT . . . 92

6. Distribution of Subjects with $N \hat{S}^{\supset}$ in the OT . 94

7. Distribution of Literal Usage in the OT . . . 96

8. Distribution of Metaphoric Usage in the OT, Subject: Man ............. 97

9. Distribution of Metaphoric Usage in the OT, Subject: God ............. 98

10. Distribution of Metaphoric Usage in the OT, Subject: Non-human .......... . 99

11. Distribution of Verbal Aspects of $N \hat{s}^{3}$ in the Pentateuch . . . . . . . . . 103

12. Distribution of Verbal Forms in Pentateuch. . 106

13. Morphological Distribution (Finite Forms) •. 107

14. Distribution of Waw-Consecutive Forms in the 108

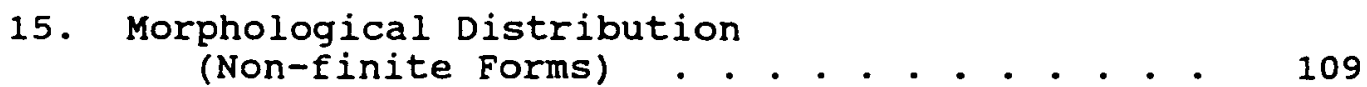

16. Syntactical Distribution ......... 110

17. Subject-Object Linkage . . . . . . . . . 111

18. Position Indicators . . . . . . . . . 113

\section{viii}


19. Distribution According to Literary Forms . . 120

20. Nāsă Own Wrongdoings . . . . . . . . . . 176

21. Nāsā? Wrongs of Others . . . . . . . . . . . 214

22. "Forgiveness" in the Pentateuch . . . . . . 281 


\section{LIST OF ABBREVIATIONS}

\begin{tabular}{|c|c|}
\hline$A B$ & Anchor Bible \\
\hline$\underline{\text { Afo }}$ & Archiv für orientforschung \\
\hline ARET & Archivi Reali di Ebla: Testi \\
\hline ASV & American Standard Version \\
\hline BASOR & Bulletin of the American oriental Research \\
\hline$\underline{\mathrm{BHS}}$ & Biblia Hebraica stuttgartensia \\
\hline $\mathrm{BDB}$ & $\begin{array}{l}\text { Francis Brown, Samuel } R \text {. Driver, and } \\
\text { Charles A. Briggs. A Hebrew and English } \\
\text { Lexicon of the Old Testament }\end{array}$ \\
\hline Bibor & Biblica et orientalia \\
\hline BSC & Bible students' Commentary \\
\hline$\underline{\mathrm{BZ}}$ & Biblische Zeitschrift \\
\hline CAD & $\begin{array}{l}\text { Assyrian Dictionary of the oriental } \\
\text { Institute of the University of Chicago }\end{array}$ \\
\hline $\begin{array}{l}\text { CBAT } \\
\text { CBO }\end{array}$ & $\begin{array}{l}\text { The Complete Bible: An American Translation } \\
\text { Catholic Biblical Quarterly }\end{array}$ \\
\hline$\underline{\text { EvTh }}$ & Evangelische Theologie \\
\hline Gesenius & Gesenius' Hebrew Grammar \\
\hline $\mathrm{HAL}_{3}$ & $\begin{array}{l}\text { Hebräisches und Aramäisches Lexikon zum } \\
\text { Alten Testament. 3rd edition }\end{array}$ \\
\hline$\underline{I D B}$ & The Interpreter's Dictionary of the Bible \\
\hline JAOS & Journal of the American oriental society \\
\hline BL & of Biblical Literature \\
\hline
\end{tabular}

$x$ 


\begin{tabular}{|c|c|}
\hline JPSV & $\begin{array}{l}\text { Holy Scriptures According to the Masoretic } \\
\text { Text. Philadelphia: The Jewish Publication } \\
\text { Society of America }\end{array}$ \\
\hline JOR & Jewish ouarterly Review \\
\hline$\underline{\mathrm{JSOT}}$ & Journal for the study of the old Testament \\
\hline$\underline{\text { JSS }}$ & Journal of Semitic studies \\
\hline$\underline{\text { KAI }}$ & $\begin{array}{l}\text { Herbert Donner and Wolfgang Röllig, } \\
\text { Kanaanäische und aramäische Inschriften }\end{array}$ \\
\hline KBL & $\begin{array}{l}\text { Ludwig Koehler and Walter Baumgartner, } \\
\text { Lexicon in Veteris Testameiti Libros }\end{array}$ \\
\hline KJV & King James Version \\
\hline LXX & Septuaginta \\
\hline MT & Masoretic Text \\
\hline NAB & New American Bible \\
\hline NASB & New American Standard Bible \\
\hline NEB & New English Bible \\
\hline NIV & New International Version \\
\hline OT & old Testament \\
\hline OTL & old Testament Library \\
\hline$\underline{\mathrm{PEQ}}$ & Palestine Exploration Quarterly \\
\hline$\underline{\mathrm{RB}}$ & Revue Biblique \\
\hline RSV & Revised standard Version \\
\hline TDNT & Theological Dictionary of the New Testament \\
\hline TDOT & $\begin{array}{l}\text { Theological Dictionary of the old Testament, } \\
\text { (English translation of TWAT) }\end{array}$ \\
\hline TEV & Today's English Version \\
\hline $\operatorname{TgN}$ & Targum Neophyti \\
\hline Tgo & Targum onkelos \\
\hline
\end{tabular}

$x i$ 
THAT

$\underline{T L Z}$

TWAT

$\underline{\mathrm{UF}}$

$\underline{\text { UT }}$

$\mathrm{VT}$

VTS

$\underline{\text { ZAW }}$

$\underline{\text { ZDMG }}$
Theologisches Handwörterbuch zum Alten Testament

Theologische Literaturzeitung

Theologisches wörterbuch zum Alten

Testament

Ugarit-Forschungen

Cyrus H. Gordon, Ugaritic Textbook

Vetus Testamentum

Vetus Testamentum, supplement

Zeitschrift für die alttestamentliche Wissenschaft

Zeitschrift der deutschen morgenländischen Gesellschaft

$x i i$ 
ABSTRACT

\section{THE USE OF NS' IN THE PENTATEUCH AND ITS CONTRIBUTION TO THE \\ CONCEPT OF FORGIVENESS}

by

Gudmundur Olafsson

Adviser: Jacques Doukhan 


\title{
ABSTRACT OF GRADIJATE STUDENT RESEARCH
}

Dissertation

\author{
Andrews University \\ Seventh-day Adventist Theological Seminary
}

\begin{abstract}
Title: THE USE OF NS $S^{\supset}$ IN THE PENTATEUCH AND ITS
CONTRIBUTION TO THE CONCEPT OF FORGIVENESS

Name of researcher: Gudmundur olafsson

Name and degree of faculty adviser: Jacques Doukhan, D.H.L., Ph.D.

Date completed: December 1992
\end{abstract}

This study investigated the use of the root $n s^{\supset}$ in the Pentateuch in an at-empt to discover its semantic relationship to the concept of forgiveness. Survey of the available literature revealed a near vacuum in this area, apart from a couple of careful but brief treatments. other studies were either very cursory or only partially relevant to the present study. Most writers tend to relegate the concept of forgiveness to the derived meaning of "remove" without substantiating it exegetically. Cognate languages affirmed the existence of the root and its range of meanings. The widest range of 
meanings and closest affinity to Hebrew was found in Akkadian. Besides its usual meanings, both languages used it in the context of caring and in handling wrongdoings. Biblical usage reveals a syntactically and semantically flexible root. Its basic sense is a deliberate, supportive upwards/onwards movement, both literal and metaphoric. Metaphoric meanings are based on the literal, either in the form of metonymy or by concretizing the abstrarts. Idiomatic expressions involving body parts were found to indicate purposeful utilization rather than just some measureable movement. In the context of $n \hat{s}^{2}$, sin and wrongdoing are viewed as concrete objects which the wrongdoer must carry. Ultimately, it leads to the death of its carrier. symbolically, the burden of sin was transferred from the wrongdoer, who carried $\left(n \hat{s}^{J}\right)$ it, to the sanctuary via the priests who bore $\left(n \xi^{3}\right)$ them on/in his body into the presence of the Lord, whose very nature it is to bear $\left(n \hat{s}^{2}\right)$ the iniquities of the people. Once a year these wrongs were removed from the sanctuary and the camp by means of a goat which carried (ns $\hat{s}^{2}$ ) them into the wilderness. No longer were they held against the people, and they were accepted by God. They could enjoy his blessings, evidenced by his caring concern for all their needs, whether spiritual or physical. Humans are to participate actively in this fatherly care, working towards the restoration of others. This whole process is 
involved in $n s^{\supset}$-forgiveness. It is not a forgetful declaration of innocence; neither does it allow the wrong to affect the relationship. Instead, it involves an active, caring concern for others and their well-being. 


\section{INTRODUCTION}

\section{General Background}

Some twenty-five years ago klaus Koch complained about the scarcity of literature and research dealing with the subject of forgiveness in the old Testament.' He, in fact, refers to only a half dozen authors, all of whom were German, who at that time had published anything substantial on the subject. ${ }^{2}$ He then concludes his survey of earlier literature with the following observation: "Ein trostloser Ergebnis! Wir stoBen auf ein schändlich vernachlässigtes Gebiet unserer sonst so aktiven und produktiven Disziplin." ${ }^{3}$

\footnotetext{
'Klaus Koch, "Sühne und sündenvergebung um die Wende von der exilischen zur nachexilischen Zeit," EvTh 26 (1966):217-239. This opinion is also shared by Th. Raitt who at the same time was writing on "The Concept of Forgiveness in the Pre-Exilic Prophets in Relation to Its Form-Historical Setting" (Ph.D. dissertation, Vanderbilt University, 1964), 2, where he observes that "surprisingly little has ever been written on the subject of forgiveness in the old Testament. In fact it has brought forth no published work in English."

${ }^{2}$ Since their discussion is, however, mostly outside the scope of this research, their contribution will only be discussed insofar as their comments become relevant to the topic.$$
{ }^{3} \mathrm{Koch}, 218 .
$$ 
In the intervening years very little has appeared to change the picture. The problem is evidently partly rooted in the fact that:

1. There seems to be uncertainty among scholars about which Hebrew terms are to be translated as 'forgiveness' and when.'

2. Some scholars do not see forgiveness as very prominent in the old Testament. Even when it is present it is not seen as basically altering the relation between God and His people and is "certainly not the centre of its scheme of salvation."2

3. There are different views as to what constitutes forgiveness really and many are not satisfied with Raitt's definition that it is "any act or expression

'This becomes quite apparent as one looks at concordances to various English translations. The frequency with which 'pardon' or 'forgiveness' occur in the OT seems to be more dependent on the understanding of the translator than on the text itself. A random sampling of "complete" concordances to nine different versions revealed the following:

$\begin{array}{lr}\text { Moffatt } & 35 x \\ \text { New King James Version (NKJV) } & 70 x \\ \text { King James Version (KJV) } & 72 x \\ \text { New International Version (NIV) } & 74 x \\ \text { American Standard Version (ASV) } & 79 x \\ \text { New American Bible (NAB) } & 81 x \\ \text { New American Standard Bible (NASB) } & 83 x \\ \text { Revised Standard Version (RSV) } & 84 x \\ \text { Living Bible (LB) } & 131 x\end{array}$

${ }^{2}$ See Ludwig Köhler, old Testament Theology, trans. A. S. Todd (Philadelphia: Westminster Press, 1957), 21718, quoted in Raitt, 45. 
of undeserved mercy by the offended party toward the offending party."I

There are mainly three Hebrew terms translated 'forgive': sālaḥ, kpr (piel), and nāsā’, of which nāsā’ is the most ambiguous. It has a wide range of meanings, both literal ${ }^{2}$ and metaphoric. ${ }^{3}$ Some of its meanings are quite obvious; others are nore ambiguous, especially when it is used to refer to interpersonal relations or in the context of sin or wrongdoings. The question is whether it is just a figure of speech in these contexts or whether its use there might signify something important about the Biblical concept of forgiveness.

We are actually faced with a surprizing paradox: Is it really a fact that one of the key concepts of salvation/redemption is almost totally absent from the religious literature of the Hebrews in the pre-christian era? Was it entirely unknown or little understood?

A systematic study of the Hebrew terms for forgiveness has yet to be undertaken. What is available

'Raitt, 27.

${ }^{2}$ In this dissertation literal use denotes an act in which a concrete subject physically acts upon a concrete object in such a way that a measureable change or movement takes place.

${ }^{3}$ As used in the present study metaphoric use denotes an action which a given subject performs in which a measureable change may not be visible, or the change does not involve a physical manipulation of the object. 
is limited either by scope, approach, or space. The

intent of the present study is to remedy that situation in Biblical scholarship.

\section{The Problem}

As the present writer began researching this topic he was also struck by the scarcity of any serious literature on the subject matter of both the usage of $n \bar{a} s \bar{a}^{2}$ in general and how it relates to the concept of forgiveness in the OT in particular. What was found was less than a handful of discussions in German,' five dissertations and/or theses in English ${ }^{2}$ during the last one hundred

\footnotetext{
'The main ones which deal substantially with the issue of forgiveness in the OT are the following: $S$. Herner, "Sühne und Vergebung in Israel," Bulletin de la Societé Royale des Lettres de Lund, 1941-1942 (Lund: $C$. W. K. Gleerups förlag, 1942): 47-121; Koch, 217-239; Bernd Janowski, Sühne als Heilsqeschehen (Neukirchen-vluyn: Neukirchener Verlag, 1982); Herbert Leroy, Zur Vergebung der Sünden (stuttgart: K B W Verlag, 1974). Rolf Knierim, Die Hauptbegriffe für sünde im Alten Testament (Gütersloh: Gütersloher Verlagshaus, 1967); Christa Göbel, "'Denn bei dir ist Vergebung . . ' sālah im Alten Testament," Theologische Versuche 8 (1977): 21-33; Hans Joachim Stoebe, Gott, sei mir Sünder gnädig (Neukirchen: Neukirchener Verlag, 1958); and Hartwig Thyen, studien zur Sündenvergebung (Göttingen: Vandenhoek \& Ruprecht, 1970).

${ }^{2}$ Elmer William John Schmitt, "Sin and Forgiveness in the old Testament" (Ph.D. dissertation, Drew Theological Seminary, Madison, NJ, 1943); Sidney Oscar Hills, "A Semantic and Conceptual study of the Root $R P R$ in the Hebrew old Testament with Special Reference to the Accadian Kuppuru" (Ph.D. dissertation, Johns Hopkins University, Baltimore, MD, 1954); Pieter de Jong, "Divine and Human Forgiveness: An Investigation into the Biblical Data about God's and Man's Forgiveness and the Relation between Them, Followed by a Comparison of the Biblical
} 
years, a few incidental notes in articles, and two, quite informative, articles in OT theological dictionaries.' None of them, however, deals with the present issue. At most, they may mention the fact that sometimes forgiveness is translated from nassã ${ }^{\supset}$. Then they launch upon a theological discussion of events where forgiveness occurs without investigating what it is or what it involves. Some scholars, like stamm, ${ }^{2} \mathrm{Zimmerl},^{3}$ and Whybray," limit their discussion to a very narrow aspect

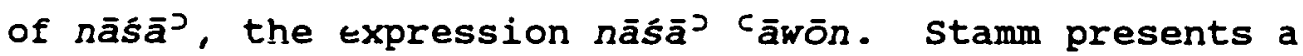
general image represented by that expression and mentions only a few examples. zimmerli, on the other hand, classifies all the passages in which the expression

Data and Some of the systematic and Ethical Approaches to the Problem" (Ph.D. dissertation, Union Theological Seminary in the City of New York, 1951); Viggo Nørskov olsen, "The Doctrine of Forgiveness in the Light of Biblical Hebrew and Greek Words" (M.A thesis, SDA Theological Seminary, Washington, DC, 1950); and Raitt, "The concept of Forgiveness in the Pre-Exilic Prophets in Relation to Its Form-Historical Setting."

'One by Fritz stolz on "Kit] $n \bar{s}^{\supset}$ aufheben, tragen," THAT (1971), 2:109-117. The other by D. N. Freedman and B. E. Willoughby on "K (b) nāsáa", "TWAT (1986), 5:626-643.

2Johann J. Stamm, Erlösen und Vergeben im Alten Testament. (Bern: A. Francke, A.-G. Verlag, 1940).

${ }^{3}$ Walther Zimmerli, "Die Eigenart der prophetischen Rede des Ezechiel," $\underline{\text { ZAW }} 66$ (1954):1-26.

${ }^{4} R$. N. Whybray, Thanksqiving for a Liberated Prophet. (Sheffield: Journal for the study of the old Testament Supplement Series, 4, 1978). For more detailed discussion of their views see chapter 1 . 
occurs, both according to scurces and contents. Whybray challenges that classification, especially where zimmerli sees substitution, which Whybray does not believe in.

others, like stolz, on the one hand, and Freedman and Willoughby, on the other hand, in their highly informative articles, are, by the very nature of the articles, limited to some general observations regarding the significance and interrelationship of the data involved. This does not mean that they are unaware of the issues, but rather that space prevents them from doing more than giving a few hints which need to be picked up and pursued further.

For Knierim the study of the use of $n \bar{a} \bar{s} \bar{a}^{2}$ is only secondary to his main project, but he succeeds in bringing out some interesting implications, which invite further investigation: subjects such as its use in interpersonal relations, or its use with wrongdoing as an object. Most of these articles are, however, only tangentially relevant to the present study since they deal almost exclusively with the theology or ethics of forgiveness and usually omit any serious discussion of the Hebrew terms employed for the concept. They are, therefore, only referred to briefly when they relate directly to the issue at hand. 


\section{Justification of study}

The contention of the present study was that a systematic contextual' study of the uses of the root nāsáa in the Hebrew Bible is needed, especially its usages in interpersonal relations and in the context of sin or wrongdoing for a clearer understanding of what it might possibly reveal concerning the Biblical concept of forgiveness. Dictionaries present quite a wide range of meaning, and the Bible translations often reveal the fact that the translators appear to be more dependent on their preconceived ideas about forgiveness than the particular meaning the terms may have.

James Barr, the principal advocate today of the importance of the Biblical context over against etymology and root meanings, has repeatedly pointed out its importance for determining the meaning of a particular word within it. ${ }^{2}$ Some scholars, such as J. F. A. Sawyer,

\footnotetext{
'In contrast to a pure etymological word-study, which traces the origin of a word back to its known or theoretical root; and semantic study, which is the historical and psychological study and classification of changes in the signification of words and forms; a contextual study looks at how the immediate verbal context, in which a particular word occurs, helps to explain the meaning of that word or expression.

'James Barr has in several books and articles attacked the popular trend, especially associated with the Biblical Theology Movement, to build theological castles on the shifting sands of Hebrew and Greek morphology, syntax, and etymology. of his books on the subject the most influential was definitely The Semantics of Biblical Lanquage (Oxford: Oxford University Press, 1961). Its main
} 
wonder, however, whether there is not still some evidence that the "'root'. . . [as a] recurring group of consonants common to several words, carries with it some common element into words and contexts in which it occurs?"l He comes to the conclusion that there is definitely evidence "for the significance of the root as a sense-bearing element in some contexts, "2 but these must be tempered by "the context of situation," which he feels is a more important factor in determining the meaning of a word than

thesis is that "theological thought of the type found in the NT has its characteristic linguistic expression not in the word individually but in the word-combination or sentence. - . [Since] important elements in the NT vocabulary were not technical . . . the attempt to relate the individual word directly to the theological thought leads to the distortion of the semantic contribution made by words in contexts; the value of the context comes to be seen as something contributed by the word, and then it is read into the word as its contribution where the coniexi is in fact different. Thus the word becomes overloaded with interpretative suggestion" (233-234). Moisés Silva, in his book Biblical Words and Their Meaning (Grand Rapids: Academie Books, 1983), 25-26 summarizes Barr's criticism in this respect in the following way: (1) paying much attention to a word and (usually) its derivatives often leads to an exaggerated estimate of etymological studies, (2) the danger of "illegitimate totality transfer," meaning that any one instance of a word will not bear all the meanings possible for that word, (3) ignoring what may look like small differences between the ways the word is used, (4) concentrated study of one word seldom leads to the very important examination of semantically related terms, and (5) a rundamental danger to confuse the word for reality.

'John F. A. Sawyer, "Root Meanings in Hebrew," JSS, $12 / 1(1967): 41$.

\footnotetext{
${ }^{2}$ Ibid., 49 .

${ }^{3}$ Ibid. , 47.
} 
the lexical context. Therefore, there must always be a balanced interchange between the "meaning" of a word and the thrust of the context in which it is found, as Freddy De Meyer has pointed out.!

In regard to the etymological rendering of the words it must je noted that a word obtains its specific meaning by its use in the sentence. One has always to investigate how a word is used in a particular context.

The story of Joseph's interpreting the dreams of the baker and butler illustrates this point. In both cases he uses the same expression--nāsä ${ }^{\supset}$ rós--which he then further qualifies to indicate the different fates that awaited them.

Speaking to the butler Joseph says:

Within three more days Pharaoh will lift up your head

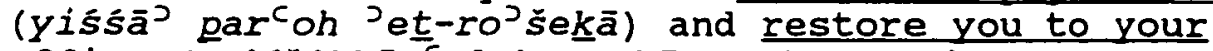
office (wah šlb blkā cal-kannekāa) and you will put Pharaoh's cup into his hand according to your former custom when you were his cupbearer.

The whole context clearly indicates that the

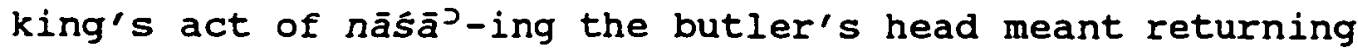
him to his former position of honor before the king. The concept of forgiveness is definitely present, as some translations indicate. ${ }^{3}$

\footnotetext{
'Freddy De Meyer, "Buber's Translation of the Bible," Louvain Studies 7/3 (1979):217.

${ }^{2}$ Gen $40: 13$, 19-22.

${ }^{3} \mathrm{NASB}$ and $\mathrm{NAB}$ do so in a footnote, as does Traduction oecuménique de la Bible (Paris: Alliance biblique universelle--Le cerf, 1982).
} 
To the baker Joseph says:

Within three more days Pharaoh will lift up your head

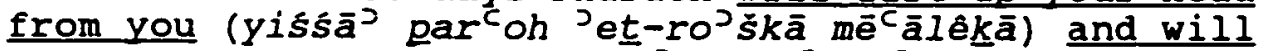

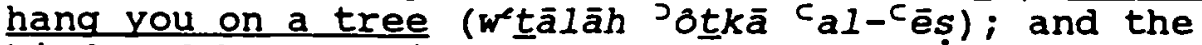
birds of heaven will eat your flesh off you.

The structure of Joseph's answer is the same in

both cases: (1) introductory statement, (2) judgment, (3) qualification of the judgment, and 4) the results of the judgment. The fact that Joseph qualifies the intent of $n \bar{a} \bar{s} \bar{a}^{\supset}$ in these two insiances leads to the inevitable question: Is this just a play on words (homonyms), or does this indicate one root with a basic meaning which is then qualified by the context?

Another example is found in the concluding plea of Moses as he intercedes for the people of Israel following their rehellious attitude as the spies reported on their findings in the promised land.'

Pardon. I pray, the iniquity of this people

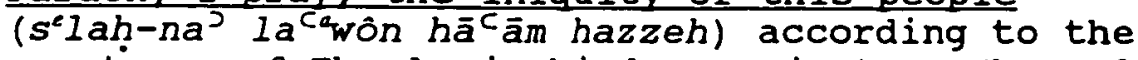
greatiness of Thy lovingkindness, just as Thou also

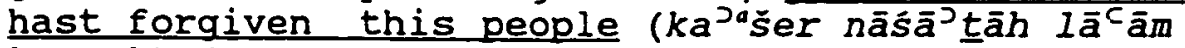
hazzeh) from Egypt even until now.

Both the parallel structure and the context seem to support the 'forgiveness'-aspect of $n \bar{a} \bar{s} \bar{a}$ ', but at the same time they connote God's protective support of and sustaining paternal care for his people." Again we are

'Num $14: 19$.

${ }^{2}$ This concept is amply represented in the Pentateuch and is considered in more detail in this research. We find texts where God is likened to a father who carries his 
faced with similar questions: is there a 'forgiveness' aspect in nās̄à , or is this just a play on homonymous words, one meaning 'forgive,' the other 'carry' or 'sustain'?' Is the meaning in these contexts somewhat different from the one where God is presented as someone who $n s^{2}$ his people like a father his son? ${ }^{2}$ And, how does this usage relate to expressions like nāsā’ pānim and $n \bar{a} \bar{s} \bar{a}^{\supset}$ ro’s, both of which, at times, convey an attitude of forgiveness? Or, to summarize: Does nāsáa really include the concept of forgiveness as we understand it, or is that meaning simply a matter of interpretation? But, if it is, what aspects of forgiveness does it reveal?

\section{Purpose and Delimitations}

Purpose

It was the purpose of this research to investigate the usages of the Hebrew verbal root nāsia ${ }^{\supset}$ in the Pentateuch, especially in the context of interpersona relations and in connection with sin and wrongdoing in order to ascertain if the context and usage might provide

young son (Deut 1:31) or like an eagle carrying her young ones (Deut $32: 11$ ).

'That impression is inevitable as one looks at various translations. Some translate here 'carry,' others 'forgive.' of English translations, only NEB translates here 'bear with'; others use 'forgive,' 'pardon.' The French Traduction oecomenique de la Bible uses 'support.'

${ }^{2}$ Deut $1: 31 ; 32: 11$. 
a clearer understanding of the Biblical concept of forgiveness by determining the following:

1. Is there any indication if the root nāsā? has a basic meaning--"root-meaning"--which informs the various usages, or are the various shades of meaning exclusively determined by the context in each case?

2. Does the Biblical concept of forgiveness fit within the semantic range of $n \vec{a} \mathbf{s} \bar{a}^{2}$, or is there some evidence of more than one root?

3. What--if anything--does the use of the root nāśā about forgiveness suggest about the Pentateuchal and/or the Biblical concept of forgiveness?

\section{Delimitations}

With that purpose in mind the following delimitations were established:

1. The study was a Biblical contextual' study, avoiding, as far as possible, to enter into the areas of systematic theology, philosophy, and ethics.

2. The research limited itself to the use of the verbal root nāśa in the Pentateuch. A survey of the general usage in the old Testament revealed that it was fairly evenly distributed throughout. The decision to limit the study to the Pentateuch was based on the following considerations:

\footnotetext{
'See p. 7, footnote 1 for definition.
} 
a. Practical. With its 169 occurrences of the verbal root $n \bar{a} s \bar{a}{ }^{\supset}$ the Pentateuch appeared to present a good cross-section of the general usage in the old Testament, and an examination of all 654 cases would have extended the study considerably.

b. Semantic. The Pentateuch was found to have the highest ratio of metaphoric uses, within which the concept of forgiveness is most likely to be found.

c. Theological. The Pentateuch is traditionally seen as the theological foundation of both the Bible and Hebrew/Christian religion.

For the sake of clarification some of its synonyms are noted and similar usages in other books of the OT examined for comparison and/or corroboration. The nominal derivations are acknowledged and briefly examined for the sake of completeness, since they do not appear to contribute significantly to the current discussion.

3. It was outside the range of present research to trace in detail the etymology of the root nāsía . Its existence and usage in some major cognate languages are noted, but the emphasis is rather on its usage in the final form of the Massoretic text of the OT.' The

\footnotetext{
'Several scholars have in recent years stressed the importance of viewing the present text as a unit in reaction to the atomizing effect of the dominant historical-critical method. Brevard $S$. Childs in his Introduction to the old Testament as scripture (Philadelphia: Fortress Press, 1979), 76-77, claims that
} 
Biblical text is accepted in its present form without attempting to analyze its "sources" or tracing its developmert, since that appears irrelevant for the understanding of its message. The texts are viewed in their cultic or non-cultic setting, the standard literary categories of narratives, poetry, or legal texts are considered, and the usages within these categories evaluated and compared.

4. Many of the usages are quite obvious, as they deal with the lifting or carrying of literal objects. Those texts are not analyzed individually in detail, but rather examined in groups. Contextual analysis is reserved for those passages in which nāsa $\bar{a}^{2}$ is used in the context of sin andior wrongdoing or in interpersonal relationships.

5. However tempting it might be to establish a complete Pentateuchal concept of forgiveness, it is not attempted here. Such a study would have to include as well all terms related to that process and their contexts.

"it is only in the final form of the biblical text in which the normative history has reached an end that the full effect of this revelatory history can be perceived. . - The final form of the text performs a crucial hermeneutical function in establishing the peculiar profile of the passage." Rolf Rendtorff, The old Testament, trans. John Bowden (Philadelphia: Fortress Press, 1986), 130, concurs with Childs: "The final form of the old Testament bocks and the theological intentions expressed in them must be taken seriously in a quite different way from what has so far been the norm in old Testament scholarship." 
Many of them are used outside of texts where náśa ${ }^{\supset}$ is used and therefore fell outside the scope of the present research. This study limited itself to investigating that aspect or 'theology' of forgiveness which is revealed by the term nāśa $\mathbf{a}$.

These delimitations are not to impiy that other aspects are unimportant, but rather it is believed that a thorough investigation of a representative sample of the use of nāśa provides a reliable clarification of its meaning and usage and will enhance the understanding of the term in general and its use in interhuman and divinehuman relations in particular.

\section{Methodology}

In order to reach this goal the present research followed this general procedural outline:

1. The overall approach was from the general to the specific. Therefore the research begins with a survey of the lexical meanings of $n \vec{a} \dot{s}^{-}{ }^{j}$ as listed by major lexicographers. In many cases this provides the first and only indication of what a word means. A review of the faw articles dealing with the semantic and theological significance of the term then follows.

2. Next an examination of the root nāśa ${ }^{\supset}$ in Semitic languages is undertaken. Because of the undisputed pan-semitic distribution of this term, the 
study limited itself to considering examples from three representative languages: Accadian, Ugaritic, and Aramaic. These are selected because (a) they are 'older' and/or contemporary with Hebrew, (b) considerable body of documents is readily available in all of these languages, and (c) there is reasonable evidence of cultural interaction between these peoples in the period under investigation.

This information is not automatically taken to be determinative for the Biblical meaning, however, for studies have shown that the Biblical meaning of terms should be evaluated in their own literary and cultural context, even though the etymology may relate them to terms in 'older' and/or contemporary languages.'

3. After this general survey the field of investigation is narrowed down to that of the old Testament in general and the Pentateuch in particular. The use of nāsā’ is analyzed statistically according to

\footnotetext{
'See Bernd Janowski's abstract of his dissertation "Sühne als Heilsgeschehen" in TLZ, 106 (1981):779, where he discusses this problem in connection with the root kpr: "kann, die Wahrscheinlichkeit einer sprachlichen Übernahme von akk. kaparu oder von arab. kafara ins Hebräische vorausgesetzt, zugleich mit sachlicher Entsprechung gerechnet werden? Selbst wenn, wie wir annehmen, die sprachliche übernahme von akk. kuppuru "kultisch reinigen" . . . ins Hebräische wahrscheinlich ist, . . . sind dennoch zahlreiche, über idiomatische und syntaktische Unterschiede hinausgehende Sachdifferenzen $z u$ konstatieren, die die Annahme einer sachlichen Entsprechung $z w i s c h e n$ hebr. $K P R$ und akk. kuppuru als sehr problematisch erscheinen lassen."
} 
the Hebrew division of the old Testament. The purpose is (a) to establish if any particular morphological/ semantic patterns or usages are in any way related to either (i) the time, (ii) the kind of literature, (iii) sources, or (iv) authorship, and (b) to discover if there are any indications of more than one root of $n \bar{a} \bar{s} \bar{a}^{2}$.

4. The general use of $n \bar{a} \bar{s} \bar{a}^{2}$ in the Pentateuch is then investigated, classified, and evaluated, with the classification system coming--as far as possible--from within the texts themselves rather than being imposed from without. Along the way we will be looking for any hints or indications of nāsā’ being used as a technical term. 5. Then follow two sections containing exegesis of those texts in which the 'forgiveness' aspect most likely appears; texts involving (a) interpersonal relations in expressions such as nāsāj + human beings as

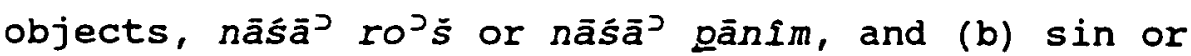

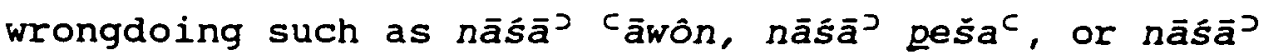
hẹt ${ }^{2}$. An attempt is made to discover how, or if, these expressions are related to a basic meaning of $n \bar{a} \bar{s} \bar{a}^{\supset}$ or if they are simply idiomatic expressions devoid of any relationship with the basic meaning of nāsā?. These particular terms have been selected, because they are used in contexts within which the concept of forgiveness is frequently found, and until now they have received only a 
limited attention, in spite of their importance for the understanding of this crucial issue in Biblical theology.

6. The paper finally looks at the relationship between the meaning of $n \bar{a} \bar{s}^{\supset}$ and the concept of forgiveness and how it relates to, or what it reveals about, the Biblical concept of forgiveness.

7. Finally, the evidence is summarized and evaluated within the framework of the stated delimitations.

Unless otherwise indicated, translations of Biblical texts are from the New American Standard Bible. 


\section{CHAPTER I}

\section{SURVEY OF EARLIER STUDIES}

Three sources are basically available for this aspect of the present research. First are Hebrew lexica,' which by definition merely acknowledge the existence of a given term, give a few examples of its usage, and mention its closest equivalents in a modern language. Second are semantic/theological studies, which deal directly with the basic concept of the term in general, give its shades of meaning in a given context, and add the significance for the theological understanding of a particular passage. And third are books and/or articles which deal with it indirectly, often more or less incidentally in relation to some other topic or term.

The fact that these make up only a handful of authorities, and they are all limited in their treatment by the nature of their articles or subject, means that the traditional critical evaluation of their material does not seem fair. Instead, their work is acknowledged, surveyed, and briefly evaluated and commented upon as needed.

'I.e., translations from Hebrew to one of the modern Western languages such as English, French, German, etc. 


\section{Lexical Listings}

In this section we examine the data as presented by five major lexicographers in the last 150 years, beginning with G. Gesenius,' "the father of modern Hebrew lexicography," his revisers and followers both in Germany ${ }^{3}$ and the Anglo-Saxon world, down to the most recent contributions in our time." since more than 90 percent of the Biblical usage is in the Qal (see table 5), we concentrate on that form. Not all of the translation possibilities are noted, but the emphasis is on the general rendering of the term, indicating its semantic

'Guilielmi Gesenius, Thesaurus Philologicus Criticus Linguae Hebraeae et Chaldaeae Veteris Testamenti (Lipsiae: Sumtibus Typisque Fr. Chr. Guil. Vogelii, 1835).

${ }^{2}$ Edward F. Miller, The Influence of Gesenius on Hebrew Lexicoqraphy (New York: Columbia University Press, 1927), 11 .

${ }^{3}$ Julius Fuerst, A Hebrew and Chaldee Lexicon to the old Testament, trans. Samuel Davidson (London: Williams \& Norgate, 1867).

"Edward Robinson, Hebrew and English Lexicon of the old Testament (Cambridge: Houghton, Mifflin \& Co., 1882). Francis Brown, Samuel R. Driver, and Charles A. Briggs, eds., The New Brown, Driver, and Briggs Hebrew and Engl ish Lexicon of the Old Testament (Grand Rapids: Baker Book House, 1981).

${ }^{5}$ Ludwig Koehler and Walter Baumgartner, Lexicon in Veteris Testamenti Libros, published in 1953. It has since been updated and revised by a group of scholars as a third edition under the name Hebräisches und Aramäisches Lexikon zum Alten Testament (Leiden: E. J. Brill, 196790). In spite of the fact that both of the original authors have died, they are, however, still listed as the main authors. The two editions will be referred to as KBL and $\mathrm{HAL}_{3}$ respectively. 
scope and those expressions in particular which are most relevant to the present study, expressions involving

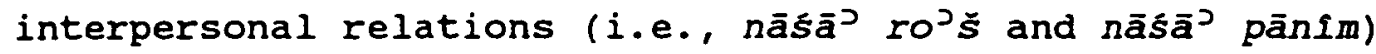
and those that involve sin and/or wrongdoing.

\section{G. Gesenius}

\section{General Scope}

Gesenius' published his major Hebrew lexicon in 1835. In it he classifies the meanings of nāsa $\bar{a}^{\supset}$ into four main groups or categories which have both a literal and metaphoric sense. The first (Category I) has the sense of "take up," "lift up," "raise"; the second (Category II) has the meaning of "to take," "to take away." In the third group (Category III) are meanings such as "to get," "to receive," or "to obtain." The final group (Category IV) has the meaning "to take upon oneself," "to bear," or "to carry" both literal burdens and responsibility or sorrow. ${ }^{2}$

\footnotetext{
'Gesenius has become the basis for several translations and/or editions. One of them is Edw. Robinson, Hebrew and English Lexicon of the old Testament, on which the following discussion is based, since it follows the Latin edition of Gesenius closest, according to Miller, 96.

'In the 17th edition of Gesenius' lexicon--Handwörterbuch über das Alte Testament, ed. Frants Buhl (Berlin: Springer Verlag, 1915/1949), 523-24--the three basic meanings are listed as (1) heben, erheben, aurheben (both literal and metaphoric); (2) tragen, ertragen, führen; and (3) nehmen, wegnehmen, i.e. aufheben, which is equated with forgiveness. Another dictionary with similar approach is D. Eduard König, Hebräisches und aramäisches
} 


\section{Specific Meanings}

The expression nāśă together with body parts or functions Gesenius regards as "a series of pleonasms common to the Hebrews"l and basically synonymous with or used as metonymy for a specific action characteristically performed by that body part and further defined by the context. These involve such objects as the hand for taking an oath, doing violence, in prayer or adoration, or beckoning; the eyes for beholding, longing, or desire; the voice for weeping, rejoicing, shouting, or uttering; the soul in longing; or the heart in adoration. All of these expressions are listed in Category $I$. The translations and comments indicate that Gesenius considers them mostly literal.

Nāsāa ro’ś has basically a literal meaning, according to Gesenius' listings. In certain contexts it may mean "being cheerful and happy" or to "lift up anyone's head from prison" (which were mostly underground), implying "to bring one out of it" (Category I), or it may imply "the removal of the head," as in the case of Pharaoh's baker (Category II). Finally, it is used in

Wörterbuch (Leipzig: Dieterich'sche Verlagsbuchhandlung, 1936), 288-89. He also lists three basic meanings: (1) aufheben, erheben; (2) vegnehmen especially used about guilt, therefore = forgive. This meaning leads to nehmen in general, and finally (3) tragen, especially as it relate to consequences of guilt.

'Robinson, 696. 
the context of "taking the sum" of or "numbering" (Category III).

Another related expression is nāśa $\bar{a}^{\supset}$ pānsm "lift up one's own countenance," which may imply "conscious rectitude, cheerfulness and confidence," or "beholding with kindness" (Category I). It is also used concerning the acceptance of someone, and "is primarily used of a king or judge, who receives or admits those who visit him with salutations and presents, and favors their cause.": This acceptance can have both a positive connotation--"to accept" and "grant one's request"--or a negative one of "being partial" (Category III).

When nāśs $\bar{a}^{2}$ is connected with words for sin or wrongdoing, it may either have the sense of removal, thus "to expiate," "to make atonement for," "to forgive," or "pardon" (Category II); or it emphasizes the aspect of carrying, thus "bearing the sin (or guilt) of anyone," i.e., "to take upon oneself and bear the punishment of sin" (Category I \& IV).2

Gesenius classifies the Hebrew expressions according to their various meanings rather than giving the various meanings of each expression. He interprets most expressions involving body parts and functions as

'Ibid., 696. There is, however, no textual evidence for this interpretation.

${ }^{2}$ Ibid. , 697. 
involving an upwards movement or an increase in magnitude, and he gives no indication of the existence of idiomatic expressions conveying the idea of utilization of some body part or function, even though he has aluded to that idea.' Forgiveness is associated with the the idea of removal, and in interpersonal relations nāśă implies acceptance.

\section{J. Fuerst}

\section{General Scope}

$$
\text { Fuerst }{ }^{2} \text { published his lexicon to the OT in } 1857 \text {, }
$$

some twenty years after Gesenius' Thesaurus. In many respects he is quite heavily influenced by Gesenius. ${ }^{3}$ He gives the basic meaning of nāsã as "to stretch up," "raise up," "make ascend," based on Arabic cognates which have the idea of "extending upward," "to rise high," "be prominent" or "stretched out." These he considers forming the background for the Biblical meaning."

From these basic meanings he classifies the usages of nās $\bar{a}^{\supset}$ into five main groups, the first of which (Category I) is related to bodily functions and has the meaning "to raise." The second group (Category II)

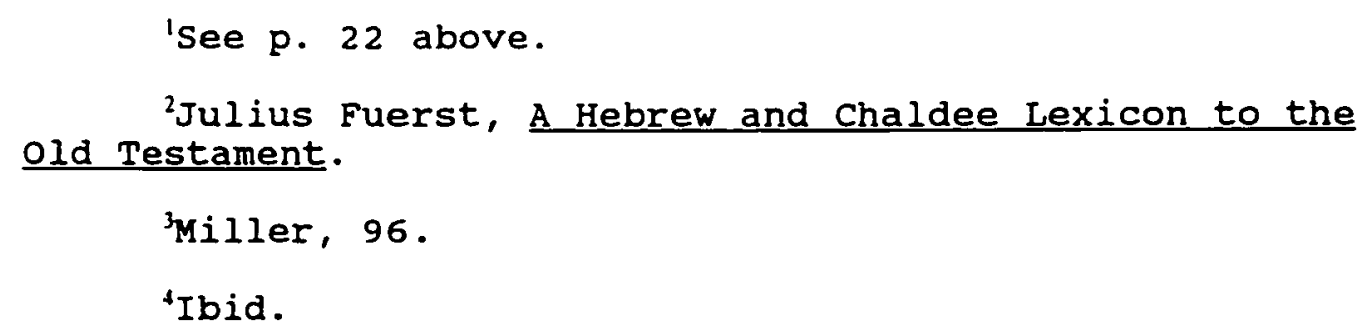


consists only of intransitive meanings such as "to be high, eminent, prominent," whereas the third (Category III) is transitive and contains the sense of removal, i.e., "to take away (or: off)," "to lift up (or: away)," "to carry off (or: away)" or "to lead." The fourth group (Category IV) has the basic idea of "to take" derived from the meaning of "to raise." As such it is parallel to läqah. The fifth and final group (Category $V$ ) has the meaning of "to bear," based on the idea of lifting.

\section{Specific Meanings}

When body parts or functions are involved, the meaning basically indicates an upwards movement, either literal or quantitative. Most are in Category $I$. When lēb heart is the subject, it means "to make proud or haughtv" or "to stir up" (Category I). Other expressions involve the following body parts as objects: feet for walking, hand for swearing, entreating, praying, or waving; eyes for looking, beholding, or longing; voice for weeping, exulting, rejoicing, or uttering aloud; and soul for striving.

$$
\text { Nāsás ro’’́ can have several meanings, depending }
$$
on its context. Basically, it means to lift up the head and "going along with a cheerful spirit" (Category I).' It can also imply the taking "up of one's person (from

'Ibid., 951. 
humiliation, the depth of a prison), i.e., to redeem, to free him" (Category III), ' or it may have the sense of "take the sum of" or "to number" (Category IV). Nāsā̃ pānfm has basically a similar connotation, that of "going along with the face raised aloft" (Category I), ${ }^{2}$ but on the basis of the meaning "to take" it also implies "accepting the person, i.e., to have a friendly regard for one, to admit and not to turn away from one," "be gracious, kind," "to have regard to," "to favour," or "to take the side of one with partiality" (Category IV).$^{3}$

When used with words for sin or wrongdoing it means "to carry off" or "to take away sin," i.e., to forgive it, or "to expiate an offence" (Category III). In certain contexts it may also indicate the "bearing of the punishment (for sin) which one takes upon oneself."

Fuerst does not depart greatly from Gesenius' approach. The groups are similar, but Fuerst appears freer and more interpretative in his translations. He holds basically to the literal meanings and does not point out the idiomatic use of many of the expressions, even though he frequently supplements them with metaphoric

\footnotetext{
'Ibid., 952.

${ }^{2}$ Ibid., 951 .

${ }^{3}$ Ibid.
} 
interpretations. In interpersonal relations nāsāo implies the process of lifting an individual from humiliation. Forgiveness is equated with the removal of sin.

F. Brown, S. R. Driver, and C. A. Briggs

\section{General scope}

The dictionary by Brown, Driver, and Briggs,' or $B D B$ as it is usually referred to, is probably the most popular Hebrew dictionary on the market. Nominally, it is based on Gesenius' lexicographic works, but in many respects it is a new work both as to material and arrangement. ${ }^{2}$ The meaning of $n \bar{a} \bar{s}^{2}$ is classified into three major groups, the first of which (Category I) is "lift," or "lift up," both in a literal and figurative sense. The latter meaning is mostly related to body parts or functions. In the second group (Category II) are those expressions which have the sense of "to bear," or "to carry" including "support," "sustain," "suffer," and "endure," whereas the final group (Category III) consists of meanings indicating removal (i.e., "to take" or "to take away").

\footnotetext{
'The New Brown, Driver, and Briggs Hebrew and Inglish Lexicon of the old Testament.

'Miller, 99.
} 


\section{Specific Meanings}

Most expressions involving body parts or functions are in Category $I$, such as lifting up the feet for walking; hand for display of power or taking an oath, in prayer or blessing; eyes implying worship or desire; voice for loud utterance; soul for desire, or uttering a name. All of these are interpreted as involving some form of a literal movement, even though that move may not be the primary thrust.

Nāsāa ro’̌́ implies "restoring someone to honor" when it is used to refer to someone else's head (Category I). In certain contexts it refers to "numbering" or "counting" (Category III). Nāsā’ pānim indicates the "lifting of someone's face," in the sense of "granting his request," or "receiving him graciously" (Category I).'

When used together with words for wrongdoing, nāsā’ sometimes indicates the inevitable that the wrongdoer will "take up (or: incur)" sin or iniquity for his wrong actions (Category I). At other times it refers to "being responsible for" or "bearing of guilt (or punishment)" (Category II), or it may refer to the removal of the sin, thus "to take away guilt, iniquity or transgression" which BDB equates with forgiveness ${ }^{1} B D B, 670$. 
(Category III).' In these contexts it is parallel in meaning with sālạ̣ and cābar (hiph). BDB follow basically the same classification as their predecessors and the relatively literal sense of expressions with nāśă . They do not point out any idiomatic use, even though they imply it in some of their comments. In interpersonal relations nāsā may signify restoration. In other contexts it may suggest the idea of support or sustaining, but $B D B$ do not relate that sense to human beings. When it is used concerning sin or wrongdoing, it may refer to three aspects: the incurring of guilt, carrying the guilt or punishment, or the taking away of the guilt or iniquity, which is equated with forgiveness.

\section{Koehler and W. Baumgartner}

\section{General Scope}

The most recent of the major Hebrew lexica on the market today is a revision of a classical work by two German scholars, L. Koehler and W. Baumgartner. ${ }^{2}$ Instead of classifying the meanings like their predecessors, they enumerate eighteen different meanings, with "carry" (tragen) listed first in the latest edition. ${ }^{3}$ Next they

'Ibid., 671.

${ }^{2}$ See above, p. 20 , note 5 .

${ }^{3}$ In the first edition, $\mathrm{KBL}$ of 1953 , this meaning is 
have a series of expressions with nāsaj , most of which involve body parts and are based on the meaning "lift," "raise" (heben, auf-, er-, hoch-). With terms related to speaking, it implies "utter," "express" (aussprechen, anstimmen). When it is in the context of burdens it refers to "take," "bear," "carry" (Eassen, (er)tragen), and finally, there are meanings such as "take," "remove" (nehmen, wegtragen).

\section{Specific Meanings}

Following the meaning "to carry" various burdens, $\mathrm{HAI}_{3}$ lists several expressions involving body parts or functions. You may lift the feet for walking, the hand either against someone or in an attitude of prayer, plea, or taking an oath; the voice for weeping, uttering, or pronouncing; the soul in desire; or the heart may nāsā? man by driving him or making him willing.

$$
\text { Nâsāo ro’s may refer to the freeing of an }
$$

individual and is related to Akkadian and Egyptian expressions for caring or healing--"sich kümmern um" or "einem Kranken die kräfte wiedergeben."' In those

listed in the 12th place, whereas "lift" is first. This interesting shift in rank appears to be more in line with the Biblical usage. (Translations of German terms from the third edition, $\mathrm{HAL}_{3}$, are my own.)

' $\mathrm{HAL}_{3}, 684 . \mathrm{KBL}, 635$, on the other hand, gives "lift the head" (indicating independence), and "restore one's repute." 
contexts it is parallel to nāsīa pānim. It may also refer to simple "head-count" (parallel with pāqad), or the literal removal of the head.'

Năsāj pañm may refer to the recovery of an individual, "being partial towards" someone, either for good or bad, or "accepting one in a friendly manner." Basically, both of these expressions are seen as literal with some metaphoric connotation.

When sins are involved, nāśa ${ }^{2}$ refers to the "bearing of the guilt," either one's own or someone else's, or it may refer to the "removal of the guilt (or punishment)," which is forgiveness.

$\mathrm{HAL}_{3}$ breaks away from the classification approach and the usual "basic idea." Instead it lists the various meanings sequentially. The Hebrew expressions are still listed according to their meaning rather than lexical morphs. There is no explicit indication of the existence of idiomatic expressions; they are mostly explained literally with a few metaphoric connotations. Interpersonal relations are not pointed out, only vaguely hinted at by expressions such as "showing favor" or "accepting kindly." To bear someone else's guilt or removing it is referred to as forgiveness. ${ }^{2}$

\footnotetext{
'Ibid., 684, 685 .

${ }^{2} \mathrm{HAL}_{3}, 685$.
} 
พ. L. Holladay

\section{General Scope}

Holladay's dictionary' is basically an abridged translation of KBL. Holladay makes his own jurgments, however, in many cases. In his treatment of nāsāj he combines the listings of $\mathrm{KBL}$ with a classification of the meanings similar to Gesenius and Fuerst above. Holladay does this by emphasizing some of the meanings, giving the impression of groups, the first of which (Category I) has to do with body parts which you "lift," or "raise (high)," mostly in a literal sense. His second emphasis (Category II) is on "to contain," relating to measuring. Then follows (in Category III) "to bear" or "carry" in both a literal and metaphoric sense. The fourth emphasis (Category IV) is on concepts such as "to support," or "bear," whether misery, guilt, or other burdens, both physical and mental. Finally, there is the idea of "to take" or "to take away" (Category V).

\section{Specific Meanings}

Under Category I Holladay lists several expressions involving body parts and functions, such as lifting the feet for walking, the hand in taking an oath, entreaty, or prayer; the eyes for looking up, the voice

'William L. Holladay, A Concise Hebrew and Aramaic Lexicon of the old Testament (Grand Rapids: Wm. B. Eerdmans Publishing Company, 1971). 
for calling, rejoicing, or weeping; the soul in longing, or the heart may lift one by driving him or making him willing.

$$
\text { Näsāl ro’s refers to "lifting one's own head }
$$

high," "lifting someone else's head," which Holladay sees as a legal expression for forgiveness, "lifting the head of Israel" by counting them, or, literally, "removing the head by beheading."

Nāśă pānfm indicates "lifting one's own face," implying confidence or being favorably disposed to someone; "lifting someone else's face," i.e., "accepting him favorably," "paying attention to," or "being partial towards" someone.

Under Category III Holladay gives examples of children being carried, a yoke being borne, or fruit being yielded. Category IV emphasizes meanings involving bearing a plight or bringing objects or loads. When nāsáa is connected with words for sin it suggests "bearing one's own guilt" and taking its consequences, "bearing someone else's guilt" and paying the penalty, or "taking his guilt away," which is forgiveness.

Holladay has basically broken away from both the rigid classification and the listing-approach of his predecessors and developed a system that combines some of the benefits of both. He lists his entries according to 
the lexical morphs rather than their meanings. He does not, however, specifically point out the idiomatic use of some of the expressions and translates them, therefore, quite literally. He has not benefited from volume three of $\mathrm{HAL}_{3}$ ' which gives "carry" as the first meaning of nāsiaj, and he does not connect the idea of support with persons. Holladay is, on the other hand, the only one of these lexicographers to state explicitly that nās̄a ro rós may in certain contexts indicate pardon. ${ }^{2}$ other interpersonal relations are demonstrated by being favorable towards someone. To take away someone's guilt and punishment is seen to be the meaning of forgiving.

\section{Summary}

Table 1 summarizes what these five representative lexicographers have to say about major aspects of the root nāśă : its basic meanings, nās $\bar{a}^{J}$ with expressions indicating interpersonal relations, and nāsā' with expressions for sin and wrongdoing. When it comes to other body parts or functions such as yād the hand, qôl the voice, cênāyim the eyes, nepeśs the soul, or lēb the heart, all these lexicographers give meanings involving the idea of lifting, either literal or metaphoric, such as an upward

\footnotetext{
'Not published until 1983 whereas Holladay's lexicon appeared in 1971.

${ }^{2}$ Holladay, 246.
} 
TABLE 1

MEANINGS OF NĀŚ $\bar{A}^{\supset}$

\begin{tabular}{|c|c|c|c|c|}
\hline & $N \bar{a} \bar{a}^{2}$ & $n a \bar{a}^{3}$ ro & 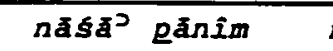 & 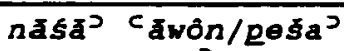 \\
\hline $\begin{array}{l}\text { G } \\
\mathbf{e} \\
\mathbf{g} \\
\mathbf{e} \\
\mathbf{n} \\
\mathbf{i} \\
\mathbf{u} \\
\mathbf{s}\end{array}$ & $\begin{array}{l}\text { a) take up } \\
\text { lift up } \\
\text { raise } \\
\text { b) take away } \\
\text { c) get } \\
\text { receive } \\
\text { d) bear, carry }\end{array}$ & $\begin{array}{l}\text { a) take, lift up } \\
\text { (out of sub- } \\
\text { ter. prison) } \\
\text { c) take the sum } \\
\text { (number) }\end{array}$ & $\begin{array}{l}\text { a) lift up the } \\
\text { face (behold } \\
\text { with kindnegs) } \\
\text { c) accept a per- } \\
\text { son } \\
\text { be favorable } \\
\text { be partial to }\end{array}$ & $\begin{array}{l}\text { d) bear sin } \\
\text { receive pun- } \\
\text { ishment } \\
\text { b) expiate } \\
\text { pardon }\end{array}$ \\
\hline $\begin{array}{l}\mathbf{F} \\
u \\
e \\
\mathbf{r} \\
\mathbf{s} \\
\mathrm{t}\end{array}$ & $\begin{array}{l}\text { stretch up } \\
\text { raise up } \\
\text { a) raise } \\
\text { b) be high } \\
\text { prominent } \\
\text { c) take away } \\
\text { d) take, accept } \\
\text { e) bear }\end{array}$ & $\begin{array}{l}\text { c) take away } \\
\text { one's head } \\
\text { take one from } \\
\text { humiliation } \\
\text { or prigon } \\
\text { redeem, free } \\
\text { d) take the sum }\end{array}$ & $\begin{array}{l}\text { d) be gracious } \\
\text { towards } \\
\text { accept one } \\
\text { esteem highly } \\
\text { be partial to }\end{array}$ & $\begin{array}{c}\text { c) carry off sin } \\
\text { take away } \\
\text { (forgive) } \\
\text { expiate an } \\
\text { offence } \\
\text { e) bear sin or } \\
\text { punishment }\end{array}$ \\
\hline $\begin{array}{l}B \\
D \\
B\end{array}$ & $\begin{array}{l}\text { a) lift (up) } \\
\text { b) bear, carry } \\
\text { c) take (away) }\end{array}$ & $\begin{array}{l}\text { a) restore to } \\
\text { honor } \\
\text { c) number }\end{array}$ & $\begin{array}{l}\text { a) grant request } \\
\text { receive grac- } \\
\text { iously }\end{array}$ & $\begin{array}{l}\text { a) incur sin } \\
\text { b) bear guilt or } \\
\text { punishment } \\
\text { c) take away } \\
\text { guilt }\end{array}$ \\
\hline $\begin{array}{l}\text { H } \\
\text { A } \\
\text { L }\end{array}$ & $\begin{array}{l}\text { a) carry } \\
\text { b) lift, raise } \\
\text { c) take, bear, } \\
\text { carry } \\
\text { d! take } \\
\text { remove }\end{array}$ & $\begin{array}{l}\text { b) lift the head } \\
\text { (independence) } \\
\text { c) take the sum } \\
\text { d) take away the } \\
\text { head }\end{array}$ & $\begin{array}{l}\text { b) lift up the } \\
\text { face } \\
\text { show favor } \\
\text { (of God) } \\
\text { accept }\end{array}$ & $\begin{array}{c}\text { c) bear guilt } \\
\text { d) take away } \\
\text { guilt or } \\
\text { punishment }\end{array}$ \\
\hline $\begin{array}{l}\text { H } \\
0 \\
1 \\
1 \\
a \\
d \\
a \\
y\end{array}$ & $\begin{array}{l}\text { a) lift, raise } \\
\text { b) contain } \\
\text { c) bear, carry } \\
\text { d) support, } \\
\text { bear } \\
\text { e) take (awzy) }\end{array}$ & $\begin{array}{l}\text { a) lift the head } \\
\text { of self =(in- } \\
\text { dependence) } \\
\text { of others = } \\
\text { pardon } \\
\text { of nation = } \\
\text { (census) }\end{array}$ & $\begin{array}{c}\text { a) lift the face } \\
\text { of self = (be } \\
\text { favorable) } \\
\text { of others = } \\
\text { accept, be } \\
\text { partial }\end{array}$ & $\begin{array}{l}\text { d) bear penalty/ } \\
\text { consequence } \\
\text { e) take away } \\
\text { guilt or } \\
\text { punishment }\end{array}$ \\
\hline
\end{tabular}


move or increased loudness or intensity.

The first column gives the basic or key meanings according to the lexicographers; the alphabetic enumeration in the other columns refers to the basic meaning from which the meaning of a given expression is derived. Words in parenthesis indicate explanations by the authors rather than translations. As the table reveals, all the dictionaries relate forgiveness to the meaning "take away" or "remove" the guilt. Only Holladay explj.citly equates nāsáa ro’̌́ with pardon.

\section{Basic Meaning}

The enumeration of data gathered from the lexicographic studies reveals a basic consensus as to the semantic range of the root $n \bar{a} \bar{s}^{2}$. It is apparently quite a neutral term which is strongly colored by its context. The closest English equivalent appears to be the verb "carry" and its wide semantic range, including the concepts of "lifting" and "moving." The exact nuance is then adapted to the needs of, and is honed by, a given context.

\section{Semantic-Theological studies}

The first in-depth article devoted to the Hebrew root nāsāj appeared only a few years ago. In this section I first analyze the few discussions of nāsāj, in general, and then look at articles which examine some of the 
specific expressions related to the present topic, in particular.

F. Stolz

Apparently, the first article written in this century to deal exclusively with nāsáa was written by $F$. Stolz and appeared in a two-volume theological dictionary in the early 1970s. Due to space limitations, however, it is little more than a lexical entry in the form of an essay.

stolz sees the basic meaning of nāsāj as "lift," "carry," "take away"--(aufheben, tragen, wegtragen)-based on the Arabic intransitive verb $n s^{\supset}$ "raise oneself." The usage, according to stolz, is mostly literal or with literal overtones when referring to bodily gestures. From the meaning "carry" is derived the sense of "suffer," "endure," "tolerate," and the subject may be the land, man, or God.

Nās̄à ro’ś implies freedom, power, and selfconsciousness, but its flexible meanings also form the basis for a play on words as Joseph interprets the dreams of the baker and butler. In the case of the butler the expression indicated freedom, whereas in the case of the baker the same expression is used literally for "taking l"Xi[] $n \dot{s}^{2}$ aufheben, tragen," THAT (1971), 2:109-17. 
the head = execute."I In certain contexts this expression refers to the taking of a census or numbering.

Nāsā' pānlm is "an expression of a good conscience or expectation."2 Used transitively it indicates to "be favorable towards," "grant," "please." When used of God it has a saving connotation. ${ }^{3}$ In texts such as Lev 19:15 the expression is used about partiality, and in Deut 10:17 it is parallel with lāqaḥ šọ̣ad "take a bribe." When $n \bar{a} \bar{s}^{2}{ }^{\prime}$ is used in connection with terms for transgression, wrongdoing, or sin, stolz distinguishes between "incurring guilt" and "carrying (the results of) the guilt." At the same time he follows Knierims with regard to the possibility of a substitutional carrying. ${ }^{6}$ The concept of forgiveness is related to the meaning "take away," "remove," in line with stamm."

${ }^{1}$ Ibid., 111 .

${ }^{2}$ Ibid.

${ }^{3}$ Ibid. , 112 .

"Apparently the expression by itself is neutral, but depending on the context it may convey a positive or negative image.

${ }^{5}$ See pages $44-47$ below.

${ }^{6}$ Stolz, 113: "Dabei ist allenfalls Stellvertretung möglich, die durch den Priester (Ex 28,38), die Söhne (Num 14,33 ), den Propheten (Ez 4,4-6) und schlieblich den Gottesknecht (Jes 53,12 , par. păga hi. "eintreten für", womit das aktive Moment bei der stellvertretung durch den Gottesknecht in sicht kommt) vollzogen werden kann."

${ }^{7}$ Stolz, 114. See Johann J. Stamm, Exlösen und 
D. N. Freedman and B. E. Willoughby

The most extensive discussion to date of the term nāśa is the result of a collaboration of Freedman and willoughby." Their basic definition of nāsa $\bar{a}^{\supset}$ is "lift," "carry," "take," indicating the physical act of lifting and/or carrying with all its ramifications and a primary emphasis on a plight rather than pleasure.

Sie bezeichnet die physische Bewegung des Hochhebens und Tragens mit allen denkbaren Assoziationen. . . . Das Hauptgewicht, sowohl materialiter als auch in emotionaler und spiritueller Hinsicht, liegt auf der Vorstellung vom Ertragen oder Aushalten: sei es von Strafe, Schmach $0 . \ddot{a} .^{2}$

The term is used in both literal and metaphoric contexts, and similar usage is also found in cognate languages. In Ugaritic and Aramaic there are only a few occurrences of the term, whereas in Accadian it occurs quite frequently in various contexts.

Freedman and willoughby devote a good portion of their study to the various metaphoric usages of nāsáa . First of all they point out that it may have the connotation of participation and caring. The term may also express God's attitude toward His people as He not only leads but also supports and sustains them. This idea

Vergeben im Alten Testament (Bern: A. Francke A.-G. Verlag, 1940), 67-69. See pages 41-43 below.

'Freedman and Willoughby, TWAT (1987), 5:626-43.

${ }^{2}$ Ibid. , 627. 
is sustained by the prophets where the verb implies acts such as "help," "lead," "support," "care for," and also-in connection with shame and guilt--"to suffer."1

When $n \bar{a} \bar{s}^{3}$ ro ${ }^{2} \bar{s}$ is used about someone else's head, it may have a literal sense of "removing the head," a metaphoric sense of "restoring to honor" or a technical sense of "taking a census" or "numbering."

Năsā pānim may have the literal sense of "lifting one's own face (as a sign of good conscience)" or a metaphcric one of "lifting someone else's face," implying the idea of being favorable or gracious towards someone. When the root is used together with terms for sin or wrongdoing, it means literally "carry/bear (the wrong)." This has three aspects, according to Freedman and Willoughby, the first of which is accepting the responsibility for one's own wrongdoing and paying the price. The price in itself cannot, however, bridge the breach in relationship caused by the wrongdoing. Forgiveness comes in and eases the burden and bridges the gap. ${ }^{2}$ Second, it may involve carrying the guilt and/or the consequences of someone else's wrongdoing. This includes taking the responsibility for what was done wrong and reconciling with the wrongdoer, as in the case of

\footnotetext{
'Ibid., 632.

${ }^{2}$ Ibid., 634 .
} 
Joseph who had suffered wrong from his brothers, but then needs to be reconciled with them. But it may also involve a symbolic act performed by or with the aid of a prophet, a priest, or a goat.'

Finally, it may involve God carrying the guilt of man, which is the essence of divine forgiveness. ${ }^{2}$ In this act the different connotations of $n \bar{a} \bar{s}^{2}{ }^{2}$ come together-"Iift," "carry," "endure," or "carry responsibility." That does not mean, however, that God ignores the wrongdoing, but rather that He does not retaliate. "He forgives but does not reject." He does not remove the consequences, but neither does he prolong them. ${ }^{3}$

\section{J. J. Stamm}

In his treatise on redemption and forgiveness in the OT $^{*}$ stamm states that it is his goal to analyze and establish the meaning of the terms and images used for forgiveness and redemption in the OT, or

die für Erlösung und Vergebung im Alten Testament üblichen Termini bsw. Bilder zu analysieren, ihre Herkunft nach Möglichkeit zu bestimmen und ihre Bedeutung innerhalb der sonstigen alttestamentlichen Heilsterminologie zu erkennen.

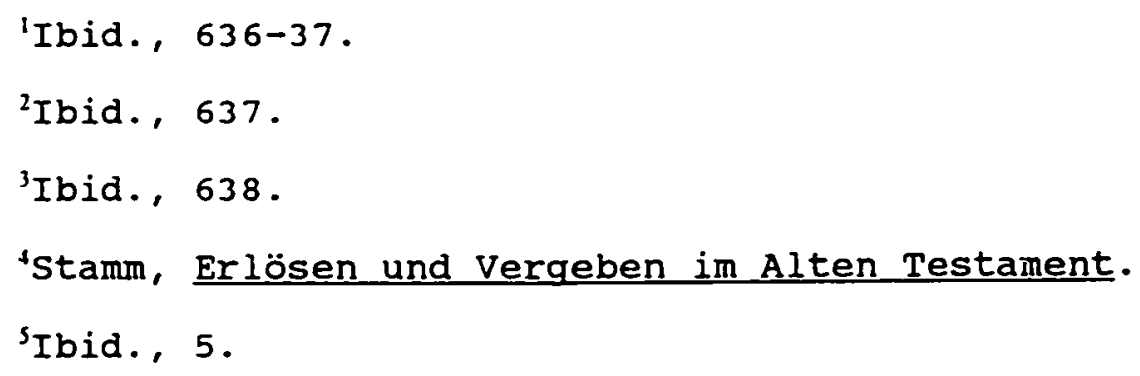


It is therefore disappointing to note that he omits, or only briefly mentions, some key terms which might enrich the understanding of the concept of forgiveness. Of the expressions involving the root nāsa ${ }^{2}$ Stamm only briefly discusses one, nās̄à ' $\bar{a}$ wôn; ${ }^{1}$ but he omits completely parallels such as nāsa $\bar{a}^{2}$ hẹt ${ }^{2}$ and nāsāo pešac ${ }^{2}$ He argues that the expressions involving nassa come primarily from the sphere of the cultus, possibly also the legal, ${ }^{3}$ but he gives no evidence or support for the latter. The former image, he maintains, on the other hand, goes back to the act performed with the goat for Azazel on the Day of Atonement when the goat nāsás the sin of the people into the desert, away from the camp. This, he contends, is what forgiveness is about.

Diese aus dem magischen stellvertretungsgedanken erwachsene Vorstellung liegt nun vielleicht auch der Wendung nāśā cāwôn "die Sünde wegnehmen = vergeben" zugrunde. Danach würde der Unschuldige die Sünde des

$$
\text { 'Ibid., 67-70. }
$$

${ }^{2} \mathrm{He}$ acknowledges their existence on pp. 69-70 but does not discuss their significance.

'Ibid., 67, 86. However, as he considers the fact that the expression nāsáa ${ }^{\circ} \bar{a} w o$ in in pre-exilic literature is found exclusively in narratives, he wonders if that implies that the expression might have had its origin in non-cultic context. Finally, he leaves the topic with one further unanswered question concerning its origin, whether it derives from the imagery of sin as being an object that needs to be taken away, or if it is derived from some particular (but unknown) custom in ancient Israel. 
Schuldigen wegnehmen oder sie wegtragen, was ins Geistige übertragen, der Vergebung gleichkommt.'

When $n \bar{a} \bar{s} \vec{a}^{2}$ is without ' $\bar{a} w o ̂ n$ or related words as an object, stamm argues that it has an abstract meaning and is parallel in meaning to sālah, ${ }^{2}$ which is the terminus technicus for forgiveness in the old Testament. The few examples he gives ${ }^{3}$ do not, however, substantiate his claim, for other evidence irdicates that it also retains its literal meaning of "lifting" and "carrying" in that position.t

Stamm's brief discussion leaves much to be desired and many unanswered questions, for it provides only a brief and somewhat inaccurate and superficial view of this particular term. He does not accomplish what he intended since he leaves the term nās $\bar{a}^{\supset}$ without establishing its meaning and significance in its context.

I'Ibid., 70.

'Ibid., 69. "Sicher ist, daß nāsāa ohne 'āwôn etc., als objekt eine ganze abstrakte Bedeutung hat und sinnbegleich mit sālah ist."

${ }^{3} \mathrm{He}$ quotes such texts as Hos $1: 6$, Gen $18: 22 \mathrm{~b}-33 \mathrm{a}$, Num 14:19, and Ps 99:8.

In Num 4:15 sanctuary objects are implied, in Num $7: 9$ and $11: 17$ the implied object is "responsibility," in Ps 89:9 it is related to "waves," in Ps 93:3 "floods," and Ps 24:4 "doors." 


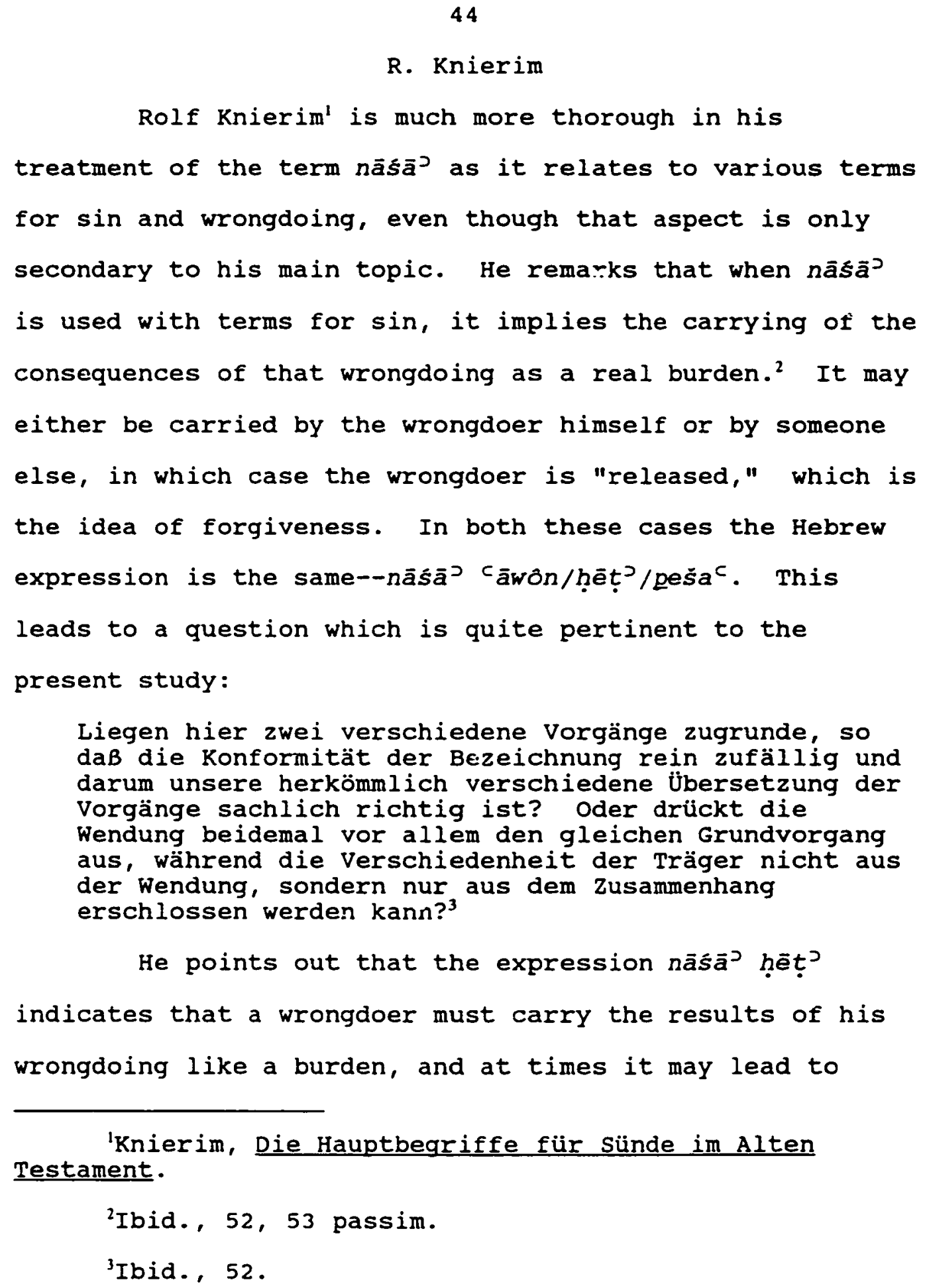


death.'

The wrongdoer cannot rid himself of that burden. He is condemned to carry it. That leads to a crucial question in the mind of many: "Is it possible that someone else--a substitute--may carry the burden?" The answer, according to Knierim, is not an unqualified "yes," "sondern von Fall zu Fall ein ungewisses Fragen und Bitten, ohne Garantie der Entlastung," but it is still a "yes." 2 There is no magic involved, as stamm maintains," but rather a dynamic relationship between the "forgiver" and the "forgiven."

Knierim argues that what really is involved in the process has been largely lost sight of in translations.

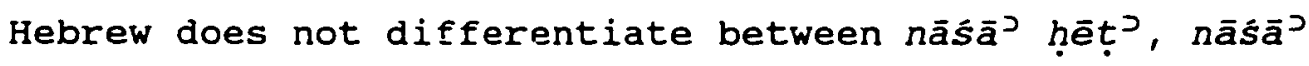

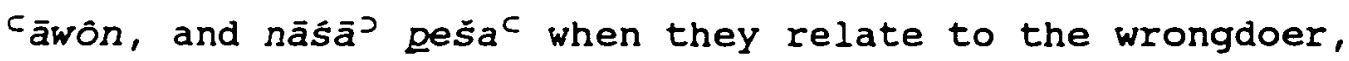
on the one hand, and when they relate to the "wronged," on the other. In Hebrew the expression remains the same;

'Ibid. Die Formel 'er soll seine Verfehlung tragen' zeigt zunächst, daß ein Täter die Folgen seiner verfehlung zu tragen hat, und zwar als eine Last, die ihn unter Umständen zu Tode bringt.

${ }^{2}$ Ibid.

${ }^{3}$ stamm, 70 .

'Knierim, 221 passim. He also points out (p. 220) that "in 15 Fällen [in the OT] haben die schuldigen den Jāwôn selbst $z$ u tragen. In 20 Fällen wird der Jāwôn eines Schuldigen durch einen anderen getragen, sei es durch den Bock, Aaron mit seinem Söhnen, die Leviten, einen Mann (für seine Frau), Vater oder Sohn, den Propheten, schlieblich durch Gott selbst." 
only the subject of the sentence changes.' The differentiation is found only in translations, with the result that the active role of the "forgiver" and the substitutionary aspect of the process, which is an integral part of the Hebrew understanding, is lost sight of.

Ist der Schuldträger ein anderer als der schuldige, so liegt für den Ausdruck nāsā' 'āwôn die Auffassung von Stellvertretung oder Tausch näher als die von

Vergebung, in der nicht mehr sichtbar wird, was der Träger eigentlich tut. ${ }^{2}$

Knierim maintains that it is only natural and to be expected that the wrongdoer has to carry his own wrongs and suffer the consequences, but the surprizing element is the fact that someone else, even God himself, may take over the burden and thus release the wrongdoer from the ultimate consequence--death. ${ }^{3}$

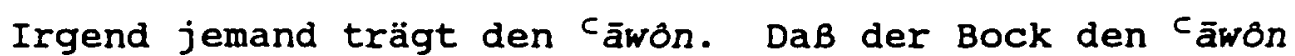
wegträgt und daB der ' $\bar{a}$ wôn infolgedessen vom Schuldigen 'weggenommen' wird, ist dabei eine bestimmte Ausprägung des Grundvorgangs. Nur daB ein anderer den cāwôn eines Schuldigen trägt, ist das Neue und Erstaunliche, in dem aus dem Ganzheits- oder Solidaritätsdenken stammenden stellvertretungsgedanken begründete. Erst recht erstaunlich ist es, wenn gesagt wird, daß Gott den 'ăwôn der Menschen trägt. ${ }^{4}$

'Ibid. , 53.

${ }^{2}$ Ibid., 221-22.

${ }^{3}$ Ibid., 51. "Einmal muß der Mensch seinen hẹt ${ }^{3}$ selbst tragen (und sterben), das andere Mal trägt Jahwe oder ein anderer Mensch den hẹt ${ }^{2}$ des Menschen weg, und der Täter lebt."

IIbid., 221. 
Knierim's approach to the text is form-historical in which he evaluates the individual expressions in light of the literary form in which they are found. Expressions containing $n \bar{a} \bar{s} \bar{a}^{J}$ and words for sin or wrongdoing are strongly formularic,' according to Knierim. The contextual connotation is also more that of "carrying" than "lifting," and forgiveness has to do with carrying the burden of guilt of someone else and releasing him from the ultimate consequence, death. ${ }^{2}$

\section{w. Zimmerli}

In $1954 \mathrm{zimmer} i \mathrm{i}$ published an article about the prophetic speeches in Ezekiel ${ }^{3}$ in which he discussed among other things the expression nāsāj cāwón in the old Testament. Altogether he finds the expression thirty-five times. In seven of them God is the subject, ${ }^{4}$ and the implication is that He forgives the sinner.

The remaining twenty-seven texts have persons as the subject, except in one instance: the scapegoat in Lev 16:22. He divides these texts into three categories: (1)

'Ibid., 51 .

${ }^{2}$ Ibid.

${ }^{3}$ Zimmerli, "Die Eigenart der prophetischen Rede des Ezechiel," 1-26, especially 9-12.

IIbid., 9. He lists the following texts: Exod 34:7; Num 14:18; Ps $32: 5 ; 85: 3 ;$ Isa $33: 24 ;$ Hos $14: 3 ;$ Mic $7: 18$. He adds Gen $4: 13$ as a possible eighth, depending on the interpretation of that text. 
those containing priestly verdict or diagnosis in which the priest confirms a certain sinful action or transgression against the sphere of that which is holy, the consequence of which is the exclusion from the congregation;" (2) a "weakened" sense--that of being responsible for something; ${ }^{2}$ and finally (3) the idea of substitution or vicariously bearing the guilt of others. ${ }^{3}$ He contends that this is especially true in such texts as Ezek 4:4-6 and Isa $53: 11$.

Zimmerli only emphasizes the "bearing" or "carrying" aspect of nāsāa, involving either one's own wrongs and responsibilities, or those cf others

'Ibid., 10. He lists the following: Exod 28:43; Lev $5: 1,17 ; 7: 18$; 17:16; 19:8; 20:17,19; 22:16; Num 5:31; $30: 16 ;$ Ezek 14:10; 44:10,12. He adds:"'Seine Schuld tragen' ist fast etwas wie eine priesterlich-medizinische Diagnose über einen Menschen, der von einem gefährlichen Krankheitszustand befallen ist, dessen Auswirkungen sich unweigerlich einstellen werden" (p. 12).

${ }^{2}$ Ibid. He lists these texts: Num 18:1 (2x); 18:23; Ezek 18:19,20 (3x).

${ }^{3}$ Exod 28:38; Lev $10: 17 ; 16: 22$; Num 14:34; Ezek $4: 4,5,6$. He says: "In szenen der stellvertretung kann er das 'Schuld Tragen' des Stellvertreters aussagen. So trägt der Sündenbock die Schuld des Volkes auf sich in die Wüste hinaus (Lev 16,22); der Sündopferbock ist von Jahwe "gesetzt, die Schuld der Gemeinde zu tragen, um für sie Sühne zu erwirken" (Lev 10,17). Gehört es auch in diesen Zusammenhang, daB Aaron in seinem stirnblatt 'die Verschuldung des Heiligen (Opfers)' trägt (Exod 28, 38)?" w. Zimmerli, Ezechiel (Neukirchen-Vluyn: Neukirchener Verlag, 1969), 1:117. 
vicariously, but he does not associate this with the idea of forgiveness. 1

\section{R. N. Whybray}

In his study on Isa $53 \mathrm{R}$. N. Whybray takes issue with zimmerli's three categories mentioned above, especially the idea of a vicarious bearing of punishment on behalf of others. He asserts that it is never present. ${ }^{3}$ on the basis of that presupposition he reexamines all the occurrences of nāsā' căwôn in the OT, and its parallel expression nāsā hẹt? ${ }^{\supset}$. He comes to the conclusion that all of the texts, which according to zimmerli imply vicarious bearing of punishment or guilt, can and should be explained differently, and the idea of vicarious suffering is "not the correct interpretation."

Instead of zimmerli's three categories, Whybray suggests six. He feels that only zimmerli's first

\footnotetext{
'In fact, the expression "forgive/forgiveness" is strangely absent in his theology. According to chong-Hyon Sung "Sündenvergebung Jesu bei den Synoptikern und seine Voraussetzungen im Alten Testament und frühen Judentum" (Inaugural-Dissertation zur Erlangung der Doktorwürde der Evangelisch Theologischen Fakultät an der Eberhard-KarlsUniversität zu Tübingen, 1984), 6, note 19 it is only found three times in Zimmerli's GrundriB der alttestamentlicher Theologie, once in connection with festivals, the others in the context of rituals (pages 112 and 113).

${ }^{2}$ Whybray, especially pages 31-57.

Irbid., 31.

Irbid., 56, 31 .
} 
category--dealing with a priestly verdict confirming some wrong act having been committed--is sound. He adds, however, two texts dealing with substitution and vicarious suffering--Num $18: 1$ and 23--which zimmerli included in his third category. Zimmerli's second and third categories "must be deleted as erroneous."I Whybray replaces them with five new categories. The first expresses a sense of a priestly verdict, but is different from zimmerli's in that it does not involve "a divine warning as to what will happen if a certain sin is committed, but [rather] a divine judgement on a sin already committed." 2 The second category expresses the sense of 'taking away guilt,' which is somewhat comparable to God's forgiving sins. The third has to do with a physical act involving the removal of guilt as in the process involving the scapegoat on the Day of Atonement which literally 'removed' the people's guilt to a distant place in the wilderness. The fourth category expresses a participation or sharing in a punishment together with the wrongdoer rather than in his place. Finally, there is the carrying (into the sanctuary) of an object representing the people's guilt, objects such as

\footnotetext{
'Ibid., 56.

${ }^{2}$ For these categories, see ibid., 56, 57 .
} 
the twelve stones with the names of the tribes, the Urim and Thummim, and the "flower" on the headgear.'

Whybray uses a very literal interpretation of

nāśă in the context of sin and wrongdoing. Each

wrongdoer must carry his own guilt or the consequences of

his actions like a burden. In the cultus the priests then carried literal objects "representing" the wrongs of the people without involving themselvas in any other way. He does not associate nāśa $\bar{a}^{2}$ with forgiveness, for that would contest his idea of non-substitution.

\begin{abstract}
Summary
stamm, zimmerli, and Whybray only discuss a very

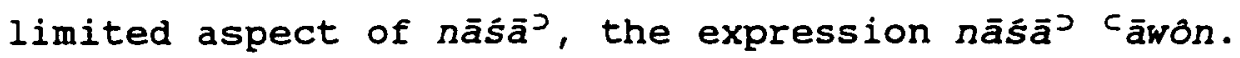
stamm sets the stage for further exploration and discussion by pointing out the relationship between forgiveness and substitution. Zimmerli classifies all the passages in which the expression occurs and shows among other how the cultic use of nāsāj is related to vicarious carrying or suffering, without explicitly associating it
\end{abstract}

IOn his discussion of this theory, see ibid., 39-40. He argues that in the same way as the stones and the Urim and Thummim are real objects, which can be put on and carried, "represent" the people or their wrongdoings, the parallel structure of the passage "requires" that the headgear must have included some tangible object, such as a flower, which could have "represented" the people's wrongdoings in some way. This interpretation, however, appears quite conjectural since there is no textual evidence for such an item. 
with the concept of forgiveness. Whybray challenges Zimmerli's classification because he is opposed to the idea of substitution. He argues rather for individual responsibility where each individual must carry the consequences of his own wrongdoing. No one else can do that.

The dictionary article by stolz is little more than a lexical entry, whereas the one by Freedman and Willoughby is much more comprehensive, but by its very nature it can only touch upon a few significant issues based on the evidence presented. This does not mean that the authors are unaware of them, but rather that space prevents them from developing them further.

For Knierim the study of the use of $n \vec{a} s \bar{a}^{\supset}$ is only secondary to his main project, but he succeeds in bringing out some interesting implications, which invite further investigation--subjects such as the use of nāsa' involving interpersonal relations or its use with wrongdoing as an object.

The evidence gathered from these sources indicates a general consensus that the basic meaning of nāsā has to do with "lifting," "carrying," or "taking," either in a literal or metaphoric sense. This triple concept is repeated with minor variations in all the sources examined. Most of the authors stress the literal sense, almost to the exclusion of the metaphoric, and they 
usually fail to point out the idiomatic use of certain expressions involving nāśă’

No one has suggested the existence of a homonymous root for the concept of forgiveness, even though they seem to suggest that the concept of forgiveness is more or less "appended" to the root rather than being an integral part of it. All of the studies see forgiveness as the removal of sin, guilt, transgression, or wrongdoing. Four of the authors--Knierim, Stolz, Zimmerli, Freedman and willoughby--point out a substitutionary aspect of forgiveness; three--Knierim, Holladay, Freedman and Willoughby--include the aspect of forgiveness in interpersonal relations, and only two--Knierim, Freedman and willoughby--give some evidence for the caring, supporting aspest of nāsā̃ . But none of them associates that aspect with the idea of forgiveness.

It seems evident, therefore, that a further study of this term, its etymology, connotations, possible relationship to phonetically related terms, and general usage is called for in order to determine its meaning and establish its significance for the concept of forgiveness. This is the subject of the present investigation in chapter 2 . 
CHAPTER II

SURVEY OF EXTRA-BIBLICAL USAGE

Cognate languages can be a boon or bane in lexical studies. The fact that a particular term exists in different languages usually implies that they are related, but its meaning may be quite different in these languages.' Nevertheless, its presence and usage in one language always provides some information which may be helpful in determining its range of meanings.

The purpose of this chapter is basically twofold: (1) to establish the presence and acknowledge the existence of the root $n \hat{s}^{\supset}$ in the larger semitic context, and (2) to examine examples of its usage, in order to determine whether they throw some light on the Biblical usage, either by means of contrast or confirmation. since it is a generally accepted fact that $n s^{2}$ is a common semitic root and is found with similar meanings in practically all semitic languages, 2 it seems most

\footnotetext{
'Compare, for instance, the root skh, which means "to forget" in Hebrew, but "to find" in Aramaic.

${ }^{2}$ See Charles-F. Jean and Jacob Hoftijser, Dictionnaire des inscriptions semitiques de l'ouest
} 
profitable to examine the range of meanings within those languages which have the closest affinity with Biblical Hebrew: Akkadian, Ugaritic, and Aramaic.' They have been selected for three reasons: (1) they represent major geographical areas and branches of the Semitic languages: the East--Akkadian; the Northwest--Ugaritic; and the North--Aramaic, and they cover an area that had close historical and cultural ties and interchange with the Hebrews in the Biblical period; (2) they represent usages that are older and/or contemporary with the Biblical usage, and (3) there is a substantial body of documents available in these languages. That survey elucidates the

(Leiden: E. J. Brill, 1965), 186-187; BDB, 669 and $\mathrm{HAL}_{3}$, 683, which list the following ocurrences: Middle (=Mishnaic) Hebrew and Palmyrene (in both of which it is also written nāsa $\bar{a}^{2}$ ), Samaritan, syro-Palestinian, Ugaritic, Canaanite, Amorite, Moabite Aramaic (where it was increasingly replaced by nāsabl) old Aramaic, Egyptian Aramaic, Biblical Aramaic, Arabic (where it means "push out," "grow," or "lift oneself up"), old South Arabic, Ethiopic, Tigri, Amharic, and Akkadian. The presence of this root in Eblaite is debated. Mitchell Dahood, "Ebla, Ugarit, and the Bible," in Giovanni Pettinato, The Archives of Ebla (Garden City, NY: Doubleday, 1981), 287 argues that the root na-se" meaning "prefect" has "a clear etymology in $n \bar{s}^{\mathrm{J}}$, 'to lift up'." Others, e.g. Edmond Sollberger, Administrative Texts Chiefly Concerning Textiles, ARET VIII (Rome: Missione Archeologica Italiana in Siria, 1986), 63; and Maria Giovanna Biga and Lucio Milano, Testi Amministrativi: Assegnazioni di Tessuti, ARET IV (1984), 314, see it rather derived from Akkadian nišu, meaning "people."

'See William S. LaSor, David A. Hubbard, and Frederic Wm. Bush, old Testament Survey (Grand Rapids: Wm. B. Eerdmans Publishing Company, 1982), 27-29, and David Ewert, From Ancient Tablets to Modern Translations (Grand Rapids: Zondervan Publishing House, 1983), 39-44. 
general use of the root $n \bar{a} s \bar{a}^{\supset}$ in the semitic world in the Biblical period. The usages are examined in the four basic semantic categories usually given in lexica, i.e., 'transport,' 'support,' 'utilization,' and relationships/ attitudes. Usually, only one example is given for a given meaning, but in some cases more than one may be mentioned if it illustrates noticeable variation in meaning.

\section{Akkadian \\ Akkadian' provides us with the greatest variety} and frequency of the use of naša which is the cognate equivalent of the Hebrew nāsã ${ }^{\supset}$. A detailed analysis of all of the available data in Akkadian is not called for in the present research, but samples of its usage and meanings are helpful in providing a basis for better understanding the pan-semitic range of this root.

The root naša appears frequently in Akkadian inscriptions. ${ }^{2}$ It has a wide range of meanings which CAD groups under five major headings, besides idioms, in the basic G form: (1) "to lift," "take up an object," (2) "to

'This section is based on data listed in The Assyrian Dictionary published by The oriental Institute in Chicago (hereinafter CAD), 11:80-112; Friedrich Delitzsch, Assyrisches Handwörterbuch (Leipzig: J. C. Hinrichs'sche Buchhandlung, 1896), 484-85; and Wolfram von Soden, Akkadisches Handwörterbuch (wiesbaden: otto Harrassowitz, 1972), 2:762-765. naša.

${ }^{2}$ CAD lists 33 two-column pages of various usages of 
transport," "carry" or "bring," (3) "to take," "accept," "receive," (4) "tc remove," "take off," and (5) "to rise," "heave," "move on." The general idea appears to be one of a (usually) upward movement which the context places almost exclusively in a durative rather than a momentary setting.

Našu as Transport

In many contexts našu conveys the idea of the movement of an object from its place. This movement may be either 'real' or 'symbolic,' that is to say, the movement itself is not the aspect being emphasized but is closely associated with the action, and often even symbolic of it.

\section{Data}

1. LU.MES ša šarra iš-ši-̋́-ni.

"The men who had carried the king."l

$$
\text { 2. șābum ša karānam ana GN i-na-aš-šu-G. }
$$

"The men who transported the wine to GN."2 i $\check{s}-\check{s} u-4$. 3. dini ša talbultu ša šarri. . ša ultu Eanna "The case of the garment of the king which they stole from Eanna. " 3 immeri tana[qqi].

'Ibid., $88 \mathrm{a}$.

${ }^{2}$ Ibid. , $87 \mathrm{~b}$.

${ }^{3}$ Ibid., $102 \mathrm{~b}$. 
"You take the water and pour it over the sheep's head" (as a part of a ritual).'

5. ás̆-s̆i [re]-ši-ia ana sin akarrab.

"I lifted my head to address a prayer to sin."2

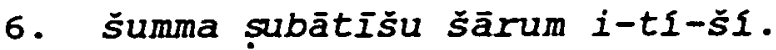

"If the wind has carried off his textiles."

7. u lu mimma maššita eriqqašu simittašu imēršu u amēlšu la na-še-e.

"And not to make any levy on his wagon, his team, his donkey, (or) his driver."4

8. Iumunšunu litbalu [lumunš]unu liš-šu-u.

"Let them take away their wickedness, let them remove their wickedness."

\section{Comments}

These examples are only a small sample of a variety of texts in which nasa is used in the context of a movement of some object, whether it be real or imaginary, from one place or position to another. The setting may be either daily events or cultic rituals, and we find both man and inanimate things as subjects and objects, and it involves such differing activities as carrying, stealing, taking or imposing a charge, or plain transport. It may

'Ibid., $83 a$.

${ }^{2}$ Ibid., $85 \mathrm{~b}$.

${ }^{3}$ Ibid., $100 \mathrm{~b}$.

IIbid., $98 \mathrm{~b}$.

sIbid., 100b. 
also include the literal movement involved in raising the head or hands in prayer, in the context of prayer and supplication to the gods, or the metaphorical act of levying taxes or removing wickedness. In the last example (8) naša is used as parallel to tabalu "take away, remove." This text, and others like it, indicate that Akkadian concretized wickedness and saw it as a burden which must be carried or removed, an idea for which there is apparently only textual evidence in Akkadian and Hebrew among these Semitic languages.'

\section{Naša as Support}

In other contexts naša conveys the idea of a support, either literally holding and carrying or caring and nurturing.

\section{Data}

išme.

1. ana šamaš bēlija qá-ti lu aš-ši [su]pītí [1u]

"I prayed with uplifted hands to my lord samas and he listened to my supplication."2

2. iš-ši Gilgāmě̉ hașșinna ana idis̆u.

"Gilgames took [or: held] the ax in his hand."

3. ina kilattēša nignakka na-šá-at.

"This does not, however, "prove" that it did not exist in other semitic languages. It only indicates that no textual evidence has been found in other languages.

I'Ibid., 106b.

${ }^{3}$ Ibid. , $84 a$. 
"She carries a censer in her two hands."

4. mala emārū $i-n a-s ̌ s-u ́-n i$.

"(Inform me) as to how much the donkeys can carry."

5. elippu kuttumu ša 110 GUR i-na-áš-šu-á.

"A covered boat that carries 110 gur."

6. ina šumēliša šerra na-šat-ma.

"In her left arm she [the demon] carries a child [it sucks her breast]."4

7. ahaka țurdamma lu-ut-ta-ši-ka.

"Send me your brother so that I can provide for you" (lit.: "lift/carry you")."

8. illak šarru...ilāni na-šu-šu.

"The king goes forward, the gods give him support."6

9. ta-at-ta-na-áš-ši la lè âmma.

"You always support the powerless."7

10. šum-ma qi-pu-tumes an-nu-tu la-a $i q-t ̦ i-b[i]-\bar{u}$

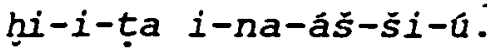

"If these agents do not point him out they become quilty (or: have to suffer punishment)."8

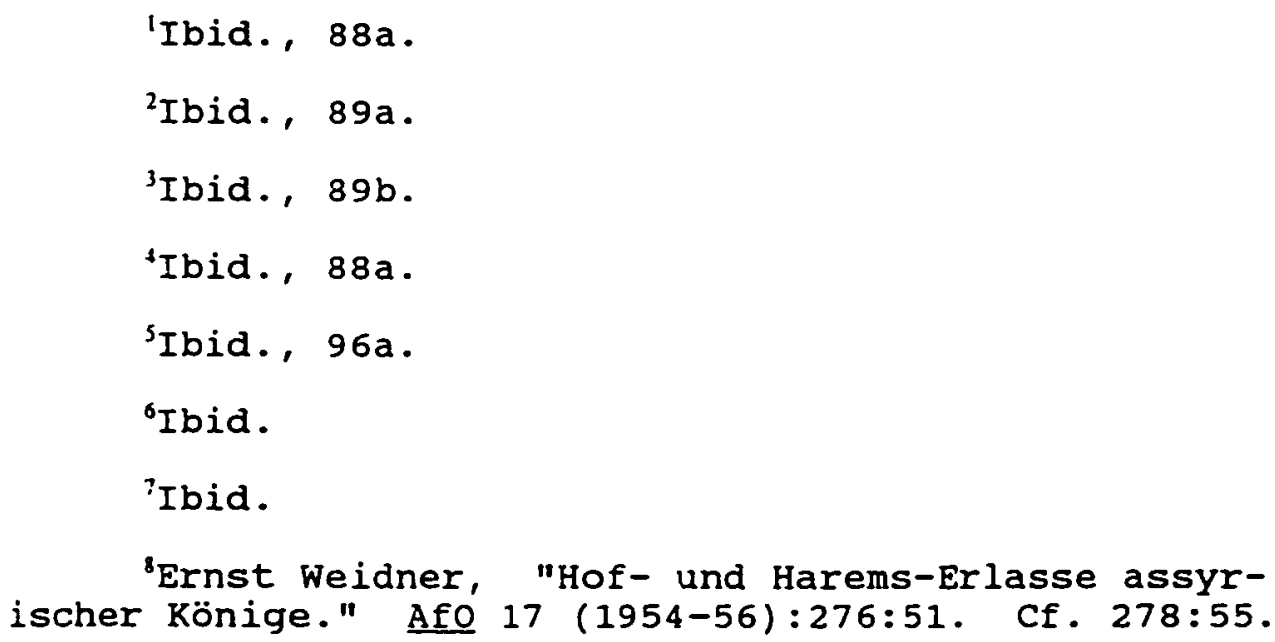


61

11. šumma ana sibat se’im u kaspim usi’am aran su'ati it-ta-na-as-si.

"If he has come forward for the purpose of (false)

testimony concerning grain or money, he shall bear the penalty of that judgment."I

12. kabtat qāssu ul ale’e na-šá-šá.

"His hand was heavy, I could not bear (it)."2

\section{Comments}

In the context of support we find a variety of usages and meanings. The social context is both daily life and the cultus. Animals, human beings, or inanimate things are both the subject and object, and the support may be in the form of holding something in an upward position, containing, sustaining and providing for, or endurir:g and suffering. Of special interest for the present study are the contexts involving both suffering and sustenance. ${ }^{3}$ In the case of wrong actions or neglect the consequences are seen as a burden which must inevitably be carried by the perpetrator."

'Code of Hammurabi, law $\$ 4$ in David Marcus, A Manual of Akkadian (New York: University Press of America, 1978), 30 .

${ }^{2} \underline{\mathrm{CAD}}, 87 \mathrm{a}$.

${ }^{3}$ As in examples 6-12.

tSee examples 10 and 11 . 
Physical needs are also seen as a "burden" but they can be alleviated by someone outside of the subject.' By meeting these needs, whether they are literal and tangible such as food or other sustenance, or such intangible ones as suffering, the supplier becomes a "bearer" or provider of the needy." Present research did not, however, find any evidence in Akkadian of this root referring to someone carrying or suffering the consequences of somebody else's wrongdoings, which would indicate the concept of forgiveness. The emphasis is usually durative and frequently includes a caring attitude. ${ }^{3}$ Whicl: of these meanings is present at any given time is, however, determined only by the context.

\section{Naša as Utilization}

In some cases the emphasis is not directly on the literal action of the verb naša, but rather on its effects as the object is utilized. Expressions involving body parts as objects appear to be periphrastic idioms, probably based on the original, literal movement which later became symbolic of or a metonym for a particular action.

\footnotetext{
'Example 7 .

${ }^{2}$ As in examples 7-9.

${ }^{3}$ This idea is also present in the noun form naša "provider" (AD, 113).
} 
Data

1. nakru dannu kakkēšu ana māti i-na-ša-a.

"A powerful enemy will brandish weapons against the country."I

$$
\text { 2. áš-ši qa-ti la šulputa ušalp[it]. }
$$

"I stretched out my hand, I touched what should not be touched." 2

$$
\text { 3. iš-ši-ma inḡsu îtamar awìlam. }
$$

"He looked up (Iit.: lifted up his eyes) and saw the man. 13

4. enūma elišs. . [ana Bēl i]-na-ás̆-ši mala ša enūma elís ana $B \bar{e} l$ [i]-na-ás̆-śu-u.

"He recites Enuma elis [before Bel], all the time he is reciting Enuma elis before Bel."

5. प̄mu 2-šú 3-šú re-e-šú șābē in-na-ás̆-šú.

"Every day the workmen are mustered several times."s $a ́ s ̌ \check{s} i$

6. Ia emūqaja balattuššunu re-eš burāṣi la a-na-

"I cannot possibly check on the gold without them."6

\section{Comments}

The general idea conveyed by these expressions is the employment of the object for a stated purpose. The
'Ibid., $84 \mathrm{a}$.
${ }^{2}$ Ibid., $85 \mathrm{a}$.
Ibid., $104 \mathrm{~b}$.
'Ibid., $87 \mathrm{a}$.
sIbid., $107 \mathrm{~b}$.
'Ibid., $107 \mathrm{a}$. 
objects of našu are mostly tools or weapons, but in a few cases parts of the body, (i.e., the hand, eyes, or head). In some of these expressions, many involving body parts, it is obvious that našu is to be taken metaphorically as a part of an idiom rather than a literal description of actions. The last five usages show this fact. In one (4) a poem, the Enūma Eliš, is being "utilized" in recitation; in the last two passages (5) and (6) the literal expression is "to lift the head of. . . " but it clearly indicates a process of checking the objects or persons for some assignments. The exact semantic background for this idiom is not clear, especially when it is used about inanimate objects, but its meaning is not disputed.' One possible idea is that $r \check{a} a$ in these contexts signifies "what is on top" or "quality" which is then "lifted up" for inspection.

Našu and Interpersonal Relations In other instances naśa describes an attitude or a relationship, either explicitly or implicitly.

\section{Data}

1. RN . - ana šarrūte ana muḩ̧išunu iš-šú-ú. "They elevated RN to be king over them."2

\footnotetext{
'For a discussion of this expression in Hebrew for census-taking, see chapter 4 below.

${ }^{2}$ Ibid., $84 \mathrm{~b}$.
} 


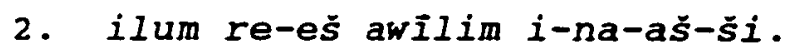

"The god will give honors to the man (or: "lift the head of the man")."1

3. i ni-iš-ši-a ina šubtišu.

"Let us remove him from his seat (of office)."2

4. Iu sabbu[tu] adu šarru re-su-[nu] i-na-áš-šu$u-n i$. . išâlúni.

"They should be retained until the king summons them and questions (them)." 3

5. minâ țubbāti eliš na-šá-ti-ma.

"Why do you assume, outwardly, a friendly attitude?"4

6. būnīšunu ša balāṭm nawrǐ́ iš-šu-šum-ma. "They turned radiantly toward him with their lifegiving
faces."5

7. alkamma ul ta-na-áš-šá-an-ni.

"Come here, will you not help me?"6

8. $\mathrm{PN} p u-u t \mathrm{PN}_{2}$ aḩišu na-ši.

"PN assumes quaranty for his brother $\mathrm{PN}_{2} \cdot " 7$

\footnotetext{
'Ibid., 108a.

2Ibid., 102a. This may also be seen as a literal "transport," but the emphasis appears to be more on the particular attitude towards the individual in the given position than on the physical removal, even though that may also have been involved.
}

\footnotetext{
'Ibid., $107 \mathrm{~b}$.

IIbid., $86 \mathrm{~b}$.

SIbid., $104 \mathrm{a}$.

${ }^{6}$ Ibid., $96 \mathrm{a}$.

${ }^{7}$ Ibid., $106 \mathrm{a}$.
} 
9. pa-ha-at puqurrānāe ša aḥāiš la i-na-ši-á.

"They do not assume responsibility for each other's claimants."I

10. ana mimmūšu inka la ta-t[a-aš]-ši.

"Do not covet anything belonging to him."2

11. ana makkūrika rapši at-ta-ši pa-ni-[ia].

"I coveted (or: Iifted my face towards) your great riches."

12. ana epēšu Esagil na-ša-an-ni 1i-ib-bi.

"I dearly wanted to (re)build Esagil."4

\section{Comments}

These expressions involving naša, indicating certain attitudes, are evidently based on an original, literal lifting up of an individual to be honored, 5 or lifting him from his place," letting him face the "act-or" for better or worse, " or else the "act-or" himself stands up for someone else taking on himself the responsibility to meet the needs of the other. ${ }^{8}$ This might involve

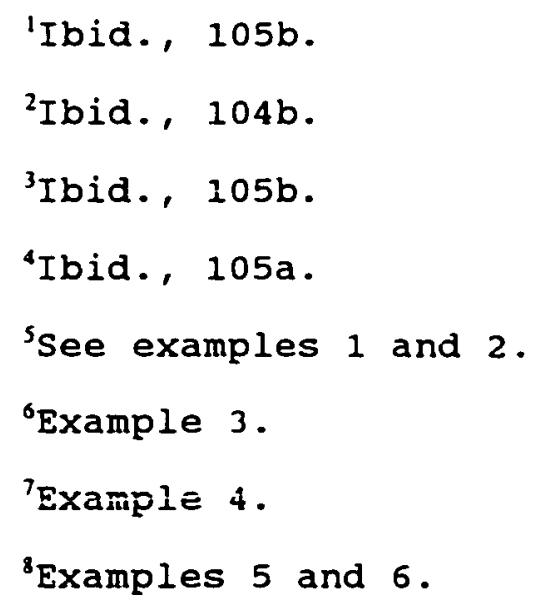


Iiability for his actions ${ }^{\prime}$ or befriending him and helping in a time of need. ${ }^{2}$ Finally, the eyes, face, or heart might be turned towards something, implying coveting or desiring it. ${ }^{3}$

Akkadian presents us with seemingly endless variety of usages of the root našu in widely different contexts, both literal and metaphoric. The term itself appears to be neutral so the meaning is quite heavily dependent on the immediate contert. However, it always retains its basic sense of an upward/onward moving action which is the result of either a deliberate move by or a natural consequence of something being done by the "actor," the effect of which is durative rather than momentary.

\section{Ugaritic}

In Ugaritic the root nša appears eighty-four times all except twelve of which are in the basic $G$ form. The remaining occurrences are in the Gt or simple passive/

\footnotetext{
'Examples 8 and 9.

${ }^{2}$ Examples 5, 6, and 7 .

${ }^{3} \mathrm{Cf}$. the English idioms "to set one's heart upon," "to make eyes $a^{t}, "$ and "set one's face toward," all of which have a similar connotation.

'According to Richard E. Whitaker, A Concordance of the Ugaritic Literature (Cambridge, MA: Harvard University Press, 1972). This section is based on the information found there and in Cyrus $H$. Gordon, Ugaritic Textbook (Rome: Pontifical Biblical Institute, 1965), hereinafter UT.
} 
reflexive form. All the occurrences are in poetical passages and the usages are both literal and metaphoric. sixty-three are in the 'imperfect' which is the most common narrative form, and the "Sitz-im-Leben" is almost exclusively mythological with gods and/or other deities being the subject in about fifty texts, or some 60 percent of the cases.'

\section{Nša as Transport}

In a few texts the verb indicates a conscious (upward) movement of an object.

\section{Data}

$1 .{ }^{c} m s \cdot m^{c} .1 y \cdot a l i y n \cdot b^{c} 1 . t \check{s} m^{c} \cdot n r t . i l m . \check{s} p \check{s} \cdot t s ̌ u . a l i y n$. $b^{c} 1.1 k t p .{ }^{c} n t . k t s ̌ t h$.

"Please, load Aliyn Baal on me! The Luminary of the gods, the Sun, hearkens. She lifts Aliyn Baal, on the shoulders of Anat she places him."

2. $h w \cdot \underline{t}^{c} \cdot n \underline{t}^{c} y \cdot h w \cdot n k t \cdot n k t \cdot y t \leq \check{i}[1 \quad a b \cdot b n \cdot i l] \cdot y t s \check{i} \cdot 1$ dr.bn.il.l mphrt.bn.[il].

"It is the offering offered, it is the sacrifice sacrificed; it is brought [to the father of the gods], it

\footnotetext{
'Analysis based on whitaker reveals other subjects, e.g., Danel--a king who sought the company of the gods-16 times; the blind ones, 2 times; and plow-oxen, 1 time. Besides, there are 10 passages in the passive with no "subject" indicated, but the fact that sacrifices are being brought implies human beings as the subject. Finally, in three cases the tablets are too damaged for identification of the subject or the general context.

${ }^{2} \mathrm{UT} 62: 12-15$.
} 
is brought to the dynasty of the gods, to the assembly of the [gods]."I

3. šu .ilm.ras̆tkm.1zr.brktkm.1n.kḥt.zblkm.

"O gods, lift your heads from the top of your knees on the throne of your prince-ship."2

4. apnk.dni] .mt .rpi .a[p]hn.gzr.mt.hrnm[Y] $y t \xi u$ ythb.bap.tğgr.tḥt . adrm.dbgrn.

"Then Danel, the man of Rpi, then the warrior, the man of Hrnmy, lifts himself up, sits in the opening of the gate among the dignitaries who are in the threshing-floor." 3

\section{Comments}

These four passages show different uses of nša, but all imply a transport or movement of some kind. In the first example it is an act of placing someone on a higher level, in the second the point of reference is the destination to which the object is brought; in the third there is a literal lifting of the head from resting on the knees indicating a change in attitude from one of fear and humility to courage and boldness. Finally, in the last example we find a human king sitting up, taking his place among other dignitaries.

'UT $2: 1,17$.

${ }^{2}$ UT $137: 27,28$. The same idea is also found in UT 137:29, except there it is in the narrative form. Baal is rebuking the gods for lowering ( $g l t$ ) their heads in the presence of the messengers of the sea. The third occurrence is in UT 126:III, 12 where 'they' are said to have' 'lifted the head of the plow-oxen on top of [. . . ] Dagan'.

${ }^{3} \mathrm{UT}, 2$ Aqht 5:4-7. Another passage, 1Aqht 21, is damaged but is apparently identical to this one. A similar expression is also found in UT $52: 53,54$ and 65. 


\section{NŠa as support}

In certain other contexts nša places the emphasis on the process of 'upholding', 'carrying' an object rather than the movement itself.

\section{$\underline{\text { Data }}$}

$m z I \cdot y m z I$.

1. yḥd.bth.sgr.almnt.škr.tškr.zbl. ‘ršm.yšu. ${ }^{\circ}$ wr

"Let the recluse scrutinize his house, the widow indeed be hired, the invalid carry the bed, the blind (?)."I

bn. dgn.bmṣdh.

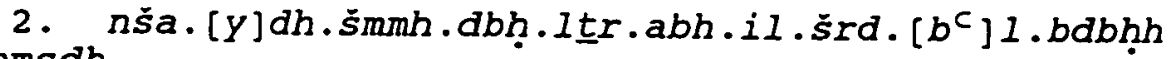

"He lifted his [halnds towards heaven, he sacrificed to Tor, his father Il, he honored [Ba]al with his sacrifice, the son of Dagan with his meal-(offering)." 2

$$
\text { 3. ša.ğr. }{ }^{c} I \cdot y d m \cdot h l b \cdot 1 z r \cdot r h ̣ t m \text {. }
$$

"Lift the mountain on the hands, the hill on top of the

\section{Comments}

Even though nša is translated as "lift" in the last two passages, the context seems to indicate a sustained action in which the hands and mountain are held 'up' rather than just the upward movement itself. In other words, the action described by the verb nša is not

\footnotetext{
'UT, Krt 96-100. Also Krt 187, 3 times in this kind of a context. The meaning of $m z l$ is uncertain.

${ }^{2}$ UT, Krt 167-171. This form occurs 2 times. In Krt 75 the same form is used as a command.

${ }^{3}$ UT $51:$ VIII, 5-6. The same expression is also found in UT $67: \mathrm{V}, 13$. The meaning of rhtm is not certain.
} 
primarily the act of lifting but rather keeping the "object" up.

$$
\text { Nša as Utilization }
$$

The usages involving utilization are almost exclusively related to body parts and functions. In these cases the verb nša has practically lost its literal meaning and appears rather to draw the attention to the employment or utilization of a particular object or organ. one example implies the use of some weapon, probably a bow and arrow.

\section{Data}

$$
\text { 1. yšu.gh.wyṣḥ. }
$$

"He lifts his voice and shouts."!

$c_{n t}$

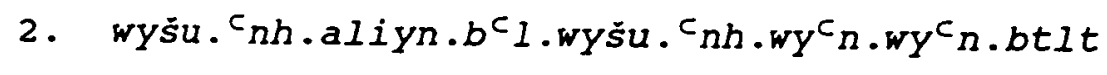

"And Aliyn Baal lifts his eyes, yea, he lifts his eyes and
sees yea, he sees the virgin Anat."

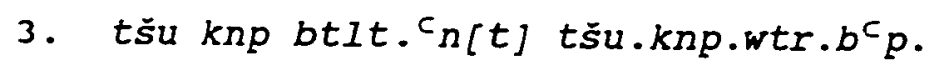

"The Virgin Anat lifts wing, she lifts wing and takes off in flight." ${ }^{3}$

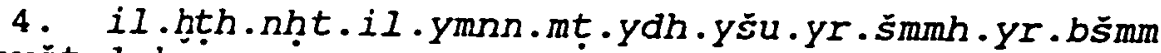
cșr.yhrtyst. 1 phim.

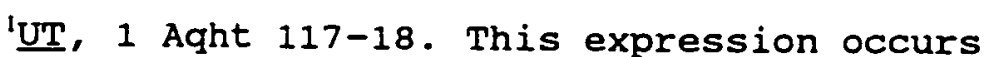
altogether 39 times in Ugaritic. times.

${ }^{2}$ UT 76:II, 13-15. Similar expression is found 13

$$
{ }^{3} \underline{\mathrm{UT}} 76: \mathrm{II}, 10,11 \text {. }
$$


"Il lowers his staff; Il lowers the staff of his hand; he raises, he shoots towards heaven, he shoots in the heavens a bird, he plucks (it), he places (it) on the coals."l

\section{Comments}

In Ugaritic nša is used metaphorically fifty-four times or about 65 percent of the occurrences, compared with the Biblical 54 percent (see table 6). By far, the most common expression involving nša is nša gh "lifting (or simply: "using") the voice" for communicating a particular message. Other expressions involve the eyes or wings. These expressions are always followed by a sequel which indicates the purpose for which the particular organ was employed, i.e., shouting (1), seeing (2), flying (3), or shooting (4). The employment of this verb in this context does not necessitate a measureable upward movement of the organ or object involved but rather the utilization of it. In Ugaritic, nša is never found in the context of interpersonal relations, referring to attitudes, or in the context of sin and wrongdoing.

\section{Aramaic}

The root $n^{e} \bar{s}^{2}$ is found eighteen times in Aramaic inscriptions and documents up to and including the Elephantine documents. ${ }^{2}$ It occurs twice on the Zakir

\footnotetext{
'UT 52:37-39. This meaning is only found here.

${ }^{2}$ The Elephantine documents are usually dated "in the days of Nehemiah" in the second half of the 5 th century
} 
stela, eight times in the Proverbs of Ahiqar, six times in the sfire inscription, and twice in the Elephantine Papyri.'

$N^{e} \bar{s} \bar{a}^{\supset}$ as Transport

In a couple of texts $n^{e} \bar{s} \bar{a}^{\supset}$ implies the movement of an object from one place to another or the changing of a position.

Data

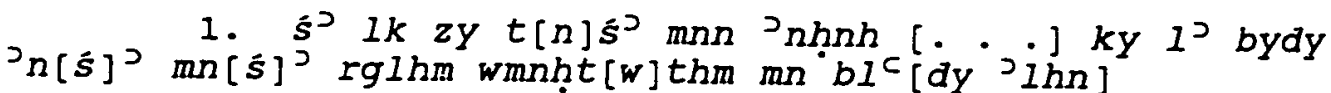
"Take whichever of us you will take, we [...] for it is not in man's power to lift their feet or set them down apart fro[m the gods]."

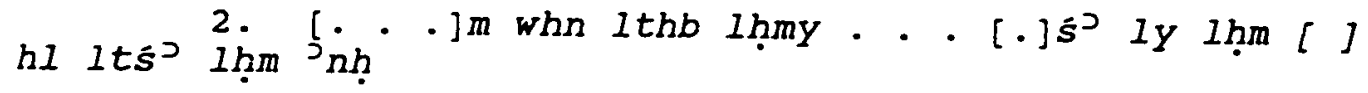

"And if you do not give me my bread [and you do not ca]rry. bread for me [and if you are] not able to carry the bread
of distress."

B.C. Emil G. Kraeling, The Brooklyn Museum Aramaic Papyri (New Haven: Yale University Press, 1953), 3. Scholars usually agree that Ezra-Nehemiah is among the last books of the OT, even though some see the book of Daniel coming later, or in the 2 nd century B.C. S. B. Frost, "Daniel" in Interpreter's Dictionary of the Bible (1962), 1:767 and $\mathrm{J}$. A. Montgomery, Critical and Exegetical Commentary on the Book of Daniel, ICC (Edinburgh: T\& T Clark, 1950), 2-5,

OT. 'It is found 3 times in the Aramaic sections of the

${ }^{2}$ Ahiqar 121-123, in James $M$. Lindenberger, The Aramaic Proverbs of Ahiqar (Baltimore: The Johns Hopkins

${ }^{3}$ Sfire I 222:B,38,39, in Herbert Donner and Wolfgang 
1bb br whn ysq ${ }^{C_{1}}$ lbbn wts ${ }^{2} c_{1}$ sptyk Ihmtty wysq ${ }^{c_{1}}$ lbb br brk wys ${ }^{\supset} C_{I}$ sptwh . . . wys' I sptyh lhmtt.. . mn $y \xi)$.

"If the idea to kill me comes to your mind and you bring it upon your lips - and it comes to the mind of your son's son and he brings it upon his lips.. . and he brings it upon his lips to kill . . . whoever brings up. . . ."l

\section{Comments}

\section{In all of these texts it is evident that the} emphasis is on the movement from one place or position to another. In the first example $n^{e} \bar{s}^{2}$ is contrasted with $n^{\text {'ḥat }}$ "come (or: set) down," in the second the context indicates the idea of bringing, and the final example of four occurrences implies a "movement" of an idea from the mind to the tongue or lips for expression. ${ }^{2}$ The subject is usually man, whose actions are deliberate.

$$
N^{e} \bar{s} \bar{a}^{2} \text { as Support }
$$

Data

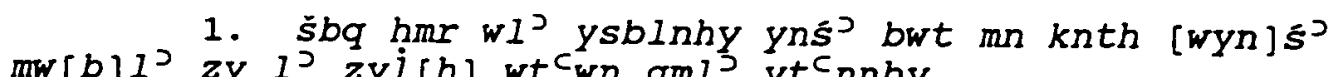
$\operatorname{mw}[b] l^{\supset}$ zy $I^{\supset}$ zyi[h] wt $c_{w n} g m l^{\supset} y t^{C_{n n h y}}$.

Röllig, Kanaanäische und Aramäische Inschriften, hereinafter KAI, (Wiesbaden: Otto Harrassowitz, 1966), $1: 42$.

'Sfire III, $224: 14,15,16,26$, in $\mathrm{KAI}: 1,45$.

${ }^{2}$ Two of the Biblical references, ${ }^{2} \bar{e} l h m \bar{a}^{2}$ nayya $\bar{a}^{\supset} \bar{s}_{\bar{e}}$ "take these vessels" (Ezra 5:15) and uneśă himmón rahā "and the wind carried them away" (Dan 2:35), also indicate the movement of certain objects to a different location. 
"The ass abandons his load and will not carry it. He will bear shame from his fellow and will carry a burden which is not his own; he will be laden with a camel's load."l

2. $n s^{2} y t h l^{2}$ wtcnt mlh wl ${ }^{\top}{ }^{\supset} y t y$ zy yqyr mn $[z p] t\left[{ }^{2}\right] n \dot{s}^{2} y t$ tbn wnsbt prn wi ${ }^{2}\left\{w l^{2}\right\}{ }^{3} y t y$ zy qlyl mn twtb.

"I have carried sand and hauled salt, but there is nothing more burdensome than [de]b[t]. I have carried straw and lifted bran, but there is nothing taken more lightly than a foreigner." 2

$$
\text { 3. kpn Imnś mšh . . . }
$$

"Ladles/bowls for carrying ointment. . . ."

$$
\text { 4. } w^{\supset} \dot{s}^{\supset} y d y{ }^{\supset} I b^{C} I \check{s}[m y] n w^{C} n n y b^{C} I \check{s} m y n \text {. }
$$

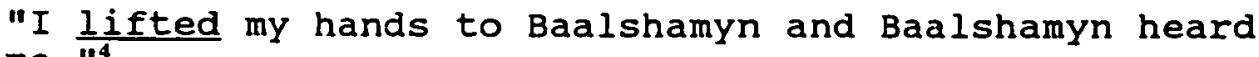
me. 114

\section{Comments}

The concept of support may be present in the form of holding a burden, containing or holding it in an upwards position. Whereas the previous category emphasized the movement from one place or position to another this category places the emphasis more on the static, durative aspect of the action than the act itself. The metaphoric usage is syntactically not different from the literal use. The subjects and objects may be persons

'Ahiqar 90 in Lindenberger, 62. The parallel structure of this passage indicates that $n \hat{\mathbf{s}}^{\mathrm{J}}$ is here used synonymously with sbl "bear," "carry."

${ }^{2}$ Ahiqar 111, 112 in ibid., 98, 99.

${ }^{3}$ Elephantine Papyrus 7:19, in Kraeling, 204.

${ }^{4}$ Zakir A:11. See also B:27, quoted in KAI 1:37. 
or inanimate things, and the only thing that differentiates between literal and metaphoric use is the context.

$$
\begin{gathered}
N^{e} \bar{s}^{2} \text { as Utilization } \\
\text { Only one passage comes close to expressing the }
\end{gathered}
$$

idea of utilization. It is not followed by a sequel, however, but the context seems to imply that the taking of the grant may be for the purpose of using it.

\section{Data} $b m[s ̦ r y n]$

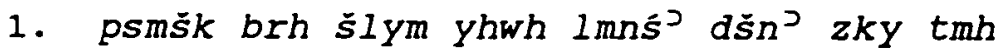

"Psamshek, his son, shall be allowed to take up that grant there in Egypt." 1

\section{Comments}

There are no available texts in Aramaic which use $n^{e} \bar{s}^{\mathbf{a}}{ }^{2}$ in the context of body parts, which is so prominent in the other semitic languages. One reason is that this root is, to a large extent, replaced with the synonymous roots $n^{e} t \underline{a l}, n^{2} s a \underline{b}, s^{e} \underline{b} a l$ and $\dot{s}^{e} q a l .^{2}$

\section{iSee Godfrey R. Driver, Aramaic Documents (Oxford:} At the Clarendon Press, 1957), 22, 23.

${ }^{2} \mathrm{Cf}$. KBL, 1101 . 
$N^{e} \bar{s} \bar{a}^{\supset}$ and Interpersonal Relations

Similar to Akkadian the Aramaic also uses the root $n^{e} \hat{s} \bar{a}^{\supset}$ in the context of relationships and attitudes. In the available extra-Biblical data only one was found in the Ahiqar corpus.'

Data

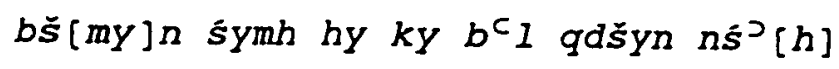

"She has been established by Shamayn; yea, the holy lord has exalted her."2

\section{Comments}

In this passage $n^{e} \mathbf{s}^{\supset}$ is parallel to sym, and the context is quite positive. Because of some merits, Shamayn has established and lifted someone up for the purpose of honoring and exalting her. None of the usages in Aramaic implies any kind of concern or caring, nor is it ever used in the context of wrongdoing.

\footnotetext{
'One text is found in the Biblical corpus: min-yômāt

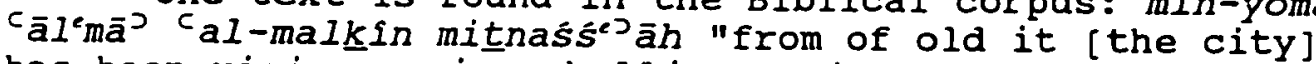
has been rising up in rebellion against the kingdom" (Ezra 4:19).

${ }^{2}$ Ahiqar 95, in Lindenberger, 68. Here it is in parallel with sym. Both this text and the Biblical quoted in the footnote above are quite interesting in that they exemplify the neutrality of the term $n^{e} \bar{s}^{2}$ itself. In the Biblical text, which is a part of a formal complaint against the city of Jerusalem that its history is replete with rebellions and now it appears to be repeating that history, it has a negative connotation, whereas it is clearly positive in Ahiqar. The indicator is only to be found in the context.
} 
Summary

The evidence from the cognate semitic languages, Akkadian, Ugaritic, and Aramaic, indicates that the root $n \hat{s}^{2}$ or its equivalent was widely used, both in literal and metaphoric senses. Based on the available data, the widest range appears in Akkadian, and the narrowest in Ugaritic. All have the ideas of transport, support, and, to some extent, utilization in common. Akkadian and Aramaic include the concept of interpersonal relations, which can either be favorable or unfavorable, but it is not found in the extant material of Ugaritic. only Akkadian uses it in the context of providing for or caring concern for someone in need. Akkadian also uses it in the context of carrying the consequences of one's own wrong actions or removing the wrong from one's own life. All of the examples indicate that the contextual emphasis is usually more on the durative aspect of either holding or carrying than merely on the momentary act of lifting. 
CHAPTER III

\section{SURVEY OF BIBLICAL USAGE}

\section{The old Testament in General}

Introduction

The root $n \dot{s}^{\supset}$ is found both in verbal and nominal forms in Hebrew. Before narrowing this research down to its usage in the Pentateuch, it may be helpful to examine its general usage in the Hebrew Bible.

In classical Hebrew there were only two characters -0 and $\boldsymbol{D}$--to represent three sounds: $\mathbf{s}, \overline{\mathbf{s}}$, and s.' Since the same character--ib--symbolized two sounds in Hebrew it has led some scholars and certain Talmudic interpretations to imply the possibility of an interchange between $n \bar{a} \bar{s}^{J}$ and nāšà /h "forget" in certain contexts relating to forgiveness. Their arguments, however, appear

\footnotetext{
'Werner Diehm, "Das Problem von $\nabla$ in Althebräischen und die kanaanäische Lautverschiebung," ZDMG 124 (1974): 222. Karl Brockelmann, Grundriss der yerqleichenden Grammatik der semitischen Sprachen (Hildesheim: Georg Olms Verlagsbuchhandlung, 1961), 1:128-129. Edward Y. Kutscher, "Contemporary Studies in North-Western Semitic," JSS, 10/1 (1965): 35-41. Joshua Blau, On PseudoCorrections in Some Semitic Lanquages (Jerusalem: The Israel Academy of Sciences and Humanities, 1970), 147.

'see Holladay, 248 .
} 
to be based more on post-biblical interpretation than on the Biblical text.' In one case there is, however, an interplay on the ambiguity of the expression nāsāa rop indicating, on the one hand, restoration of an individual to a former position and the literal lifting off of the head, in the other.' In another case there is also an

'Nisan Ararat has suggested this in certain cases in

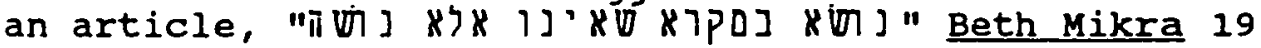
(1974): 536-548), where he argues that as you do wrong you incur guilt--you are in debt--towards whomever you wronged. This debt (guilt) needs to be paid, except in cases where the wronged nāśa your guilt and becomes your nos'e thus setting you free. Ararat sees this only when

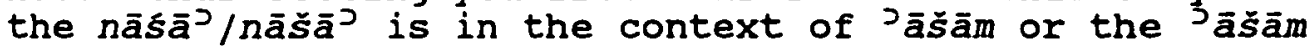
offering. In the "Talmud Yerushalmi," J. Neusner, The Talmud of the Land of Israel (Chicago: University of Chicago, 1983), 32:1:6 art. "Shebuoth," there is another attempt to indicate a $\dot{s} / \dot{s}$ interchangeability, but with a different root, as Rabbi Huna is quoted as saying in the name of Rabbi Abbahu: "The Holy one--blessed be He--before him there is no forgetting [s $\bar{s} h h]$ ] but it is as if, on the account of Israel, there is forgetting [škhn], like it is said, 'Who, o God, is like you, a forgiver of iniquity?'-written noše--for David said, 'You have forgiven tha iniquity of your people'." It is clear from the immediate context that these references are to be read with a s rather than a '́ because of their parallel with škhn. This idea of reading $\dot{s}$ instead of $\dot{s}$ when it relates to forgiveness is also expressed in the Pesikta Rabba, referring to Ps $32: 1$, "Happy is the man whose sins are forgiven" - the term to be read with a $V$ rather than a iv "da Gott unsere Sünden am Versöhnungstag in jedem Jahre in Vergessenheit bringt," quoted in Jacob Levy, Wörterbuch über die Talmudim und Midrashim (Darmstadt: wissenschaftliche Buchgesellschaft, 1963), 3:446. He does not, however, connect the root with the idea of "debt" in the same way as Mareus Jastrow in A Dictionary of the Targumim, the Talmud Babli and Yerushalmi, and the Midrashic Literature (New York: Judaica Press, 1975), 938.

${ }^{2}$ Gen $40: 13,19,20$. 
interplay between the meaning of forgiveness and caring.'

Two parallel texts present problems, and scholars are divided whether to read $n \overline{\mathbf{s} s} \bar{a}^{J}$ or nāša I "lend, "2 (hence: "obligate"). These texts are $1 \mathrm{Kgs} \mathrm{8:31}$ and $2 \mathrm{Chr}$ 6:22, "If a man sins against $h i s$ neighbor and is made to

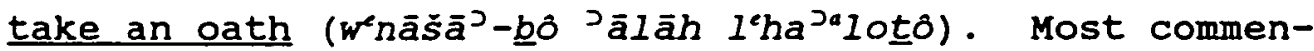
tators make no comment on the use of the root $n 5^{2}$ in this passage. Some apparently "assume" nāsä without any discussion or evidence, ${ }^{3}$ others read nās̆ă ${ }^{2}$ with the MT. ${ }^{4}$ The meaning is fairly clear in spite of this textual problem, whether it emphasizes that the man becomes obligated to take an oath or he is put under an oath, s the basic idea is the same. There is thus no textual evidence

'Num 14:19,20. This becomes evident when different translations are compared. Some translate nāśa ${ }^{\partial}$ as "carry," others as "forgive" (KJV, RSV, NASB, NIV).

${ }^{2}$ Holladay, 247 .

${ }^{3}$ E.g., John Gray, I \& II Kings (Philadelphia: Westminster Press, 1963), 206 and Charles F. Burney, Notes on the Hebrew Text of the Books of Kings (Oxford: At the Clarendon Press, 1903), 118; $\mathrm{HAL}_{3}, 687$, probably on the basis of LXX which has $\lambda \alpha \beta \epsilon \epsilon \pi$ ' $\alpha \dot{t} \tau \nu^{\nu}$ "he takes upon himself an oath" which indicates original Hebrew nāsā’

tAlbert Sanda, Die Bücher der Könige (Münster in Westfalen: Aschendorffsche Verlagsbuchhandlung, 1911), 229, and Arnold B. Ehrlich, Randglossen zur hebräischen Bibel (Hildesheim: Georg Olms Verlagsbuchhandlung, 1908, reprint 1968), 7:233, supported by the Syriac Peshitta which uses a periphrastic passive meaning literally "they cause him (i.e. he is made) to take an oath" apparently based on Hebrew nāšà ${ }^{\supset}$. This is apparently also the understanding of NASB.

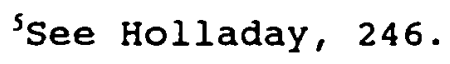


82

for any interchange between the "traditional" meaning of nāśā and any apparent homonym or phonetically related root.

\section{Distribution and Usage}

\section{General}

The root $n \bar{a} \bar{s} \bar{a}^{2}$ and its derivatives occur 885 times in the OT. They are found in all but two of its books, Obadiah and Zephaniah.' of these, 654 are the verbal root, while the rest is made up of derived denominatives. Table 2 indicates that the root is fairly evenly distributed throughout the OT corpus, especially the verbal root. The nominal forms are mostly concentrated in the Pentateuch and the Later Prophets, which also have the highest, and practically equal, concentration of the root. The Pentateuch makes up 22.4 percent of the total OT corpus, and has 29.7 percent of the total occurrences, or .75 occurrences per printed page. The Later Prophets account for 31.9 percent of the occurrences in 26.2 percent of the total text, or .68 per printed page. The lowest concentration is in the Writings which account for only 21.7 percent of the occurrences in 30.9 percent of the total text, or .39 per page.

\footnotetext{
'See appendix A.
} 
TABLE 2

DISTRIBUTION OF THE ROOT NŚ' IN THE OT

\begin{tabular}{|c|c|c|c|c|c|c|c|c|}
\hline & \multirow[b]{2}{*}{ BHS $^{\prime}$} & \multirow[b]{2}{*}{8} & \multirow[b]{2}{*}{ Verb } & \multicolumn{2}{|c|}{ Nouns } & \multirow[b]{2}{*}{ Sum } & \multirow[b]{2}{*}{$q$} & \multirow{2}{*}{$\begin{array}{l}\text { Aver } \\
\text { age }\end{array}$} \\
\hline & & & & Nāśs ${ }^{2}$ & Other ${ }^{2}$ & & & \\
\hline \multirow{4}{*}{$\begin{array}{l}\text { Pentateuch } \\
\text { Early Proph } \\
\text { Later Proph } \\
\text { Writings }\end{array}$} & 353 & 22.4 & 169 & 70 & 24 & 263 & 29.7 & .75 \\
\hline & 322 & 20.5 & 125 & 15 & 8 & 148 & 16.7 & .46 \\
\hline & 412 & 26.2 & 201 & 39 & 42 & 282 & 31.9 & .68 \\
\hline & 487 & 30.9 & 159 & $y$ & 24 & 192 & 21.7 & .39 \\
\hline Total & 1574 & 100 & 654 & 133 & 98 & 885 & 100 & .56 \\
\hline
\end{tabular}

\section{Nominal Forms}

The nominal derivations of the root $n \bar{a} \mathbf{s}^{2}{ }^{2}$ are found 231 times in the OT, of which ninety-four are in the Pentateuch. They are:t nāśf "chief," "minor king," "leader"; maśs̄ā’ "carrying," "burden," "hardship," "pronouncement"; maśsāāh "lifting up (of heavy clouds)"; maśšo "partiality"; maśs̄êt "lifting up," "tax, offering"; maśôt "pulling up," "pronouncement," "share"; $\hat{s}^{e \supset} \bar{e} \underline{t}$ "raising oneself up," "dignity," "nobility," "exaltation," "sivelling," "blotch"; and ś ${ }^{\supset}$ "height."

$N a \bar{s} i^{\supset}$ is by far the most common of the nominal forms (see table 3). Of the seventy occurrences in the

\footnotetext{
'Number of pages of printed text according to BHS. $s \Sigma^{2}$. 
Pentateuch sixty-one are found in the book of Numbers, four in each of Genesis and Exodus, and one in Leviticus. outside of the Pentateuch, thirteen are found in the book of Joshua, two in 1 Kings, thirty-seven in Ezekiel, 1 and two in Jeremiah. ${ }^{2}$

TABLE 3

DISTRIBUTION OF NOMINAL FORMS OF $N \hat{S}^{2}$

\begin{tabular}{|c|c|c|c|c|c|c|}
\hline & \multirow{2}{*}{$\begin{array}{l}\text { Penta- } \\
\text { teuch }\end{array}$} & \multicolumn{2}{|c|}{ Prophets } & \multicolumn{2}{|c|}{ Writings } & \multirow[t]{2}{*}{ Total } \\
\hline & & Early & Later & Wisd. & Other & \\
\hline 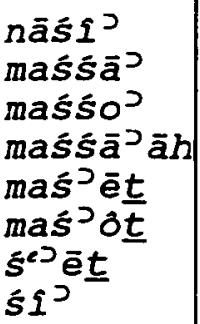 & $\begin{array}{l}70 \\
13\end{array}$ & $\begin{array}{r}15 \\
5\end{array}$ & $\begin{array}{l}39 \\
34 \\
\\
1 \\
5 \\
1 \\
1\end{array}$ & $\begin{array}{l}2 \\
4\end{array}$ & $\begin{array}{r}7 \\
10 \\
1 \\
3\end{array}$ & $\begin{array}{r}133 \\
66 \\
1 \\
1 \\
15 \\
1 \\
13 \\
1\end{array}$ \\
\hline$\underset{\frac{q}{6}}{\text { Total }}$ & $\begin{array}{c}94 \\
40.7\end{array}$ & $\begin{array}{l}23 \\
10\end{array}$ & $\begin{array}{r}81 \\
35.1\end{array}$ & $\begin{array}{r}12 \\
5.2\end{array}$ & $\begin{array}{r}21 \\
9.1\end{array}$ & 231 \\
\hline
\end{tabular}

$N \bar{a} \mathbf{s} \hat{I}^{\supset}$ is a qatil form, a nomen professionis

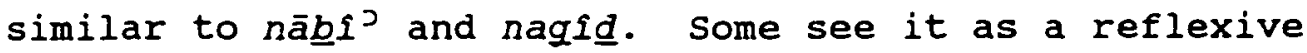
formation of the verbal root, "one who exalts oneself" or in the words of van der ploeg: "Le nāśs aurait donc été

'All of which refer to persons.

${ }^{2}$ Both of which refer to ascending clouds.

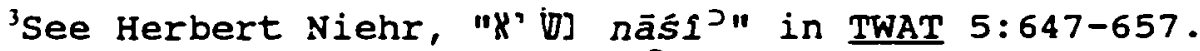
Also Oliviera Calberini, "Il nāśs' biblico nell'epoca patriarcale e arcaica," Bibor 20 (1978):65. 
l'homme qui s'élève au-dessus des autres."l others see it rather as a passive form, "the one brought/carried or lifted up." still others see an active meaning derived from such phrase as nāsāa qôl "to raise one's voice," thus being a spokesman for someone, or $n^{e} \check{s} a^{2}$ pānim, "one with a lifted-up countenance." ${ }^{3}$ Speiser suggests a more plausible and less forced interpretation as "ciuly elected chieftain" or "someone elected to that position by the appropriate council."4

of the thirteen occurrences of massia in the Pentateuch, eleven are in the book of Numbers, but it is not found in the books of Genesis and Exodus. It is a maqtal form which frequently functions as the object of the verbal action," and its basic meaning is "what is being carried," whether it be a literal load or burden or a concern in the form of an utterance in certain prophetic passages. In the Pentateuch and the Early Prophets the

\footnotetext{
'Johannes van der Ploeg, "Les chefs de peuple d'Israel et leurs titres," RB 57 (1950):50.

${ }^{2}$ See Moshe H. Gottstein, "פי (Gen 23:6), " VT 3 (1953):298-9.

${ }^{3}$ So Martin Noth, Das System der Zwölf Stämme Israels (Darmstadt: Wissenschaftliche Buchgesellschaft, 1966), 162 .

"Ephraim A. Speiser, "Background and Function of the Biblical Náś'," CBO 25 (1963):111-17, especially p. 114.

SSee H. P.-Müller, "KiDO maśsā̃ " TWAT 5:20-25, and Henrik S. Nyberg, Hebreisk Grammatik (Stockholm: Almquist \& Wiksell, 1952), 205.
} 
term is almost exclusively used in the literal sense of "a burden," whereas in the Later Prophets it has become a technical term introducing some prophecies.' Scholars have debated whether this means there are two different homonymous roots, one meaning "burden," the other "utterance," or if there is only one root meaning "burden." When used in prophetic introductions, many see the term then indicate a "burdensome" oracle--frequently one of doom--which the Lord has commissioned the prophet to deliver, ${ }^{3}$ especially against foreign nations.+ Both of these postulations are, however, inaccurate and unnecessary. As McKanes has correctly pointed out, this expression does not always introduce oracles of doom. ${ }^{6}$ Even today we have no problem with such

\footnotetext{
'See Henry S. Gehman, "The 'Burden' of the Prophets," JQR 31 (1940-41):107-21, and Pieter A. H. de Boer, "An Inquiry into the Meaning of the Term maśsāj," oudtestamentische studiën, ed. P. A. H. de Boer (Leiden: E. J. Brill, 1948), 5:214.

${ }^{2}$ So william McKane, "xio in Jeremiah 23:33-40" in Prophecy, ed. John A. Emerton (New York: Walter Gruyter, 1980), 35-54. He lists several scholars who have subscribed to that view from Rashi down to our time ( $p$. 39). See also $\mathrm{HAL}_{3}, 604$; Holladay, 217; BDB, 672 .

${ }^{3}$ So for instance Johannes Calvin in his commentary on Jeremiah. This interpretation is also proposed by Gehman, 107-21, and H. P.-Müller, 20-25.

${ }^{4}$ See H. P.-Müller, 20-25.

ScKane, 38 .

${ }^{6}$ See Prov 31:1; Lam 2:14; and Zech 12:1.
} 
expressions as "to carry a message" without it having any reference to its contents being burdensome. Maśsás in these contexts refers simply to a message being carried or brought by the prophets.

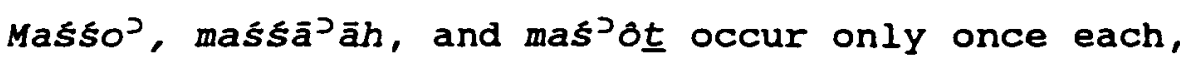
the first in the expression masso" pānsm, "partiality" or "favoritism." This nominal form indicates usually "the act of -ing" something, ${ }^{2}$ and is here equivalent to nāsa pānfm, signifying "showing favor," or "being favorable."3 Others suggest that it might also be takan as an "Aramaiclike qal infinitive of nāsā with a mem- prefix."4

Maśs̄ā'a is a hapax legomenon in Isa $30: 27$ and may have a meaning similar to maśsāo, "a burden," "an utterance," or it may mean "lifting up of heavy clouds."s Theodotian and the syriac versions evidently took the first meaning and read the $f$ inal $-h$ as mater lectionis for the masculine singular suffix -0 , thus translating it as "his burden/oracle." The inverse paralleism in the verse seems to support that reading:

'2 Chr 19:7.

${ }^{2}$ See Nyberg, 207.

${ }^{3}$ E.g., Holladay, 246 .

'Moshe Greenberg, Ezekiel 1-20, $A B$, vol. 22 (New York: Doubleday \& Co., 1983), 313 .

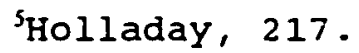

${ }^{6}$ See apparatus in BHS on Isa $30: 27$. 
(a) bo'ēr Jappo

(b) weḱobed maśśā̄āh

$\left(b_{1}\right) \dot{s}^{e} \underline{p} \bar{a} t \bar{a} y \bar{w}$ mālej a zacam

$\left(a_{1}\right)$ a l'śônô $k^{e} \bar{e} \bar{s}$ 'oknālet

(a) Burning [is] his anger

(b) and weighty [his] message

$\left(b_{1}\right)$ his lips filled with indignation

$\left(a_{1}\right)$ and his tongue like consuming fire

In lines (a) and $\left(a_{1}\right)$ "his anger" (lit.: his nose,

دappô) and "his tongue" (1'šônô) are both "on fire";

similarly, the "weight" of the message in (b) fills his

lips with indignation in $\left(b_{1}\right)$. Sabottka suggests a

different voweling of the problematic kobed massāja of

the MT by reading kābed miśs $\bar{a}^{\supset} \bar{a} h$ instead, meaning

"unerträglich"--literally "too heavy to carry"--taking it

as an infinitive construct with a feminine -āh ending.'

Oswa $1 t^{2}$ has pointed out that most modern translations ${ }^{3}$

take it, however, to refer to a dense cloud of smoke

accompanying the fire of his anger in light of Judg 20:38,

40 (where the cloud is, however, explicitly mentioned).

His alternative proposal is to take it as referring to the

'Liudger Sabottka, "Is 30,27-30: Ein Übersetzungsvorschlag" BZ, 12 (1968):242. Cf. also Gesenius' Hebrew Grammar, 2nd edition. Emil Kautzsch, ed., revised by Arthur E. Cowley (Oxford: At the Clarendon Press, 1980), $\$ 45 d$.

'John Oswalt, The Book of Isaiah 1-39, NICOT (Grand Rapids: Wm. B. Eerdmans Publishing Company, 1986), 566.

${ }^{3}$ So for instance RSV, CBAT, NIV, and TEV. 
heavy burden of punishment which God will impose upon the Assyrians.'

$$
\text { Maśot, "hoist," is probably also "an Aramaic-like }
$$

qal infinitive of $n \bar{a} \bar{s} \bar{a}^{\supset}$ with a prefixed mem and -ot ending of late Hebrew final $x$-verbs. ${ }^{2}$ It occurs only once in the MT with the meaning of "pulling up" by the roots.

$\operatorname{Mas}^{\top} \bar{e} \underline{t}$ is a segholated feminine noun formation of qal infinitive construct with a mem prefix, ${ }^{3}$ and is translated as "lifting up," "tax, offering," or "uprising," "burden," "utterance," "portion."s It occurs fifteen times in the MT, of which three are in the Pentateuch, all in the same verse ${ }^{6}$ where it has the sense of "portions"; four times it has the sense of "gifts" $;$ three times it is used about "tax" or "tribute" $i^{8}$ twice it refers to a "rising smoke," and once each of "hands

'So also NEB and JPSV.

${ }^{2}$ Greenberg, on Ezek 17:19.

${ }^{3}$ See Benjamin Davidson, The Analytical Hebrew and Chaldee Lexicon (Grand Rapids: Zondervan, 1982), \$39,4 rem. 2 .

'E.g., Holladay, 217.

${ }^{5} \mathrm{BDB}, 673$.

${ }^{6}$ Gen $43: 34$.

${ }^{7} 2$ Sam 11:8; Esth 2:18; Jer 40:5; Ezek 20:40.

${ }^{3} 2$ Chr 20:6,9; Amos $5: 11$.

'Judg $20: 38,40$. 
lifted/held up" in prayer,' a "burden" to be borne, ${ }^{2}$ and a "signal" or "message." All of these meanings convey the same basic idea of something that is carried, brought, or held.

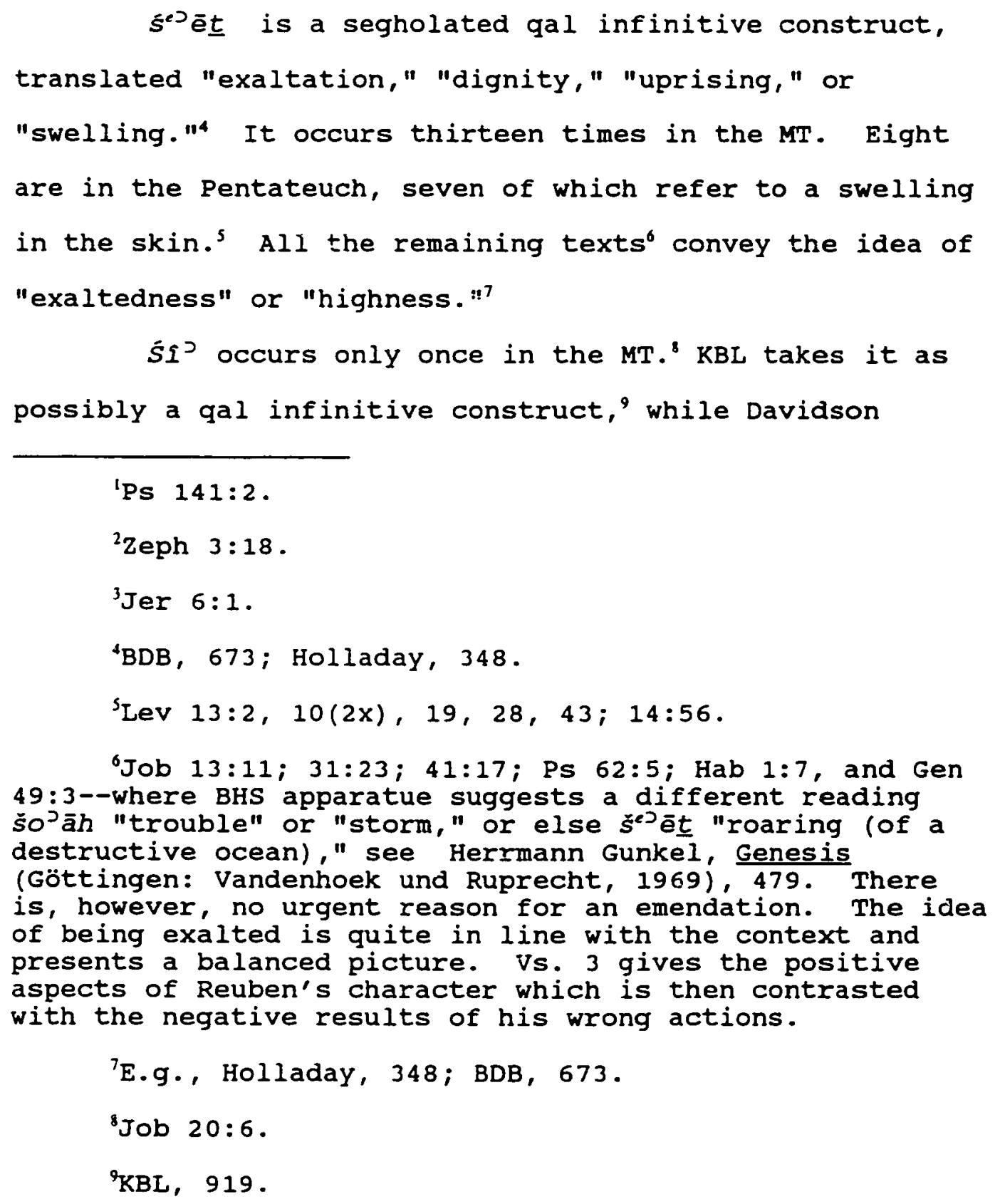


considers it as derived from a shortened form of nās $I^{2} .^{1}$ Its meaning is evidently similar to $\xi^{e \nu} \bar{e} \underline{t}$, "exaltedness," or "highness."

All of the noun forms give the impression of a more or less literal object in the form of a burden or weight which is then lifted or carried either literally or metaphorically and thus brought to the attention of others.

\section{Verbal Forms}

The distribution of the verbal forms is more uniform than that of the nouns, as table 4 shows. Of the 654 occurrences of the verb in the OT, 598 are in the Qal, or 91.4 percent. ${ }^{2}$ The proportional distribution is practically the same for the Pentateuch and the Later Prophets, or .48 and .49 per page respectively with the Early Prophets and Writings having a noticeably lower proportion. This distribution is, however, not necessarily an indication of a difference in usage related to the age of the document. Rather, the distribution seems to be more related to the contents.

Table 5, showing the distribution of the various aspects of the Qal stem in the same corpus, indicates

\footnotetext{
'Davidson, 711.

"For that reason the expression "verbal form" in the remainder of this research means the gal except in a few cases which are then specified.
} 
TABLE 4

DISTRIBUTION OF THE VERBAL ROOT NS'

\begin{tabular}{l|rrrrr}
\hline & & & & & \\
& Qal & other & Total & \& & Average* \\
\hline Pentateuch & 164 & 5 & 169 & 25.8 & .48 \\
Early Prophets & 119 & 6 & 125 & 19.1 & .38 \\
Later Prophets & 172 & 29 & 201 & 30.7 & .49 \\
Writings & 143 & 16 & 159 & 24.3 & .33 \\
\cline { 2 - 6 } & 598 & 56 & 654 & & .41 \\
\cline { 2 - 6 } & 91.4 & 8.6 & 100 & & \\
\hline
\end{tabular}

* Average refers to distribution per printed page.

TABLE 5

DISTRIBUTION OF VERBAL ASPECTS IN THE OT

\begin{tabular}{|c|c|c|c|c|c|c|c|c|}
\hline \multirow[b]{2}{*}{ QAL } & \multicolumn{2}{|c|}{ Pentat. } & \multicolumn{2}{|c|}{ Prophets } & \multicolumn{2}{|c|}{ writings } & \multicolumn{2}{|c|}{ Total } \\
\hline & $\neq$ & $\frac{8}{8}$ & $\neq$ & 8 & $*$ & 8 & $\neq$ & $q$ \\
\hline $\begin{array}{l}\text { Infinitive } \\
\text { Perfect } \\
\text { Imperfect } \\
\text { Participle } \\
\text { Imperative } \\
\text { OTHER FORMS }\end{array}$ & $\begin{array}{r}24 \\
29 \\
83 \\
14 \\
14 \\
5\end{array}$ & $\begin{array}{r}14.2 \\
17.2 \\
49.0 \\
8.3 \\
8.3 \\
3.0\end{array}$ & $\begin{array}{r}15 \\
59 \\
127 \\
58 \\
32 \\
35\end{array}$ & $\begin{array}{r}4.6 \\
18.1 \\
39.0 \\
17.8 \\
9.8 \\
10.7\end{array}$ & $\begin{array}{l}11 \\
29 \\
68 \\
23 \\
12 \\
16\end{array}$ & $\begin{array}{r}6.9 \\
18.2 \\
42.8 \\
14.5 \\
7.5 \\
10.1\end{array}$ & $\begin{array}{r}50 \\
117 \\
278 \\
95 \\
58 \\
56\end{array}$ & $\begin{array}{r}7.6 \\
17.9 \\
42.5 \\
14.5 \\
8.9 \\
8.6\end{array}$ \\
\hline Total & 169 & & 326 & & 159 & & 654 & \\
\hline
\end{tabular}

that the various aspects of the verb nāsád are also fairly evenly distributed in the oT corpus. This may indicate that the term evidently never "froze" in a fixed expression as a technical term, associated only with any one kind of action. It is rather a quite general term 
being used in connection with a variety of common, universal actions which were 'timeless,' (i.e., they did not change significantly with time). It also appears that the most frequently used aspect of the verb is the imperfect, which may imply that the highest concentration could be found in past narratives with waw consecutive.' When it comes to usage, the flexibility of the verb becomes even more apparent, as the following tables indicate. Table 6 shows the distribution of usages in general in the OT. Man is most frequently the subject -491 times or 75.1 percent of the total occurrences. In the Pentateuch, man is the subject 135 times out of 169 instances, or 79.8 percent. The highest ratio is found in the Writings, outside of the Wisdom literature; and Early Prophets, or 89 and 91.2 percent respectively, and the lowest in the wisdom literature and Later Prophets, or 61.6 and 61.7 percent respectively.

Man as Subject

The verb may be used with either a literal or metaphoric meanings. Table 6 also shows that the literal meaning is by far most prevalent in the Early Prophets with 89 occurrences out of a total of 125 , or 71.2 percent, whereas the average for the OT is 34.7 percent.

\footnotetext{
'See further discussion of the distribution of forms in chapter 4 below.
} 
TABLE 6

DISTRIBUTION OF SUBJECTS WITH $N S^{\supset}$ IN THE OT

\begin{tabular}{|c|c|c|c|c|c|c|c|c|c|c|c|c|}
\hline \multirow[b]{3}{*}{ Subj. } & \multicolumn{2}{|c|}{ Pentat. } & \multicolumn{4}{|c|}{ Prophets } & \multicolumn{4}{|c|}{ Writings } & \multicolumn{2}{|c|}{ Total } \\
\hline & \multirow[b]{2}{*}{ * } & \multirow[b]{2}{*}{ 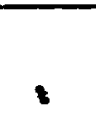 } & \multicolumn{2}{|c|}{ Early } & \multicolumn{2}{|c|}{ Later } & \multicolumn{2}{|c|}{ Wisdom } & \multicolumn{2}{|c|}{ Other* } & \multirow[b]{2}{*}{$\neq$} & \multirow[b]{2}{*}{ เ } \\
\hline & & & $\neq$ & 8 & $\neq$ & 3 & $\neq$ & 8 & $F$ & 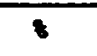 & & \\
\hline $\begin{array}{ll}M & \text { lit } \\
\mathrm{A}\end{array}$ & 42 & 24.8 & & 71.2 & 40 & 19.9 & 8 & 9.3 & 48 & 65.7 & 227 & 34.7 \\
\hline $\mathbf{N}$ met & 93 & 55 & & 20 & 84 & 41.8 & 45 & 52.3 & 17 & 23.3 & 264 & 40.4 \\
\hline GOD met & 17 & 10 & 6 & 4.8 & 44 & 21.8 & 17 & 19.8 & 2 & 2.8 & 86 & 13.1 \\
\hline $\begin{array}{lll}\mathbf{A} & \mathbf{M} & 1 \text { it } \\
\mathbf{N} & \mathbf{A}\end{array}$ & 3 & 1.8 & 1 & 0.8 & & & & & 1 & 1.4 & 5 & 0.8 \\
\hline I I met & 1 & 0.6 & 1 & 0.8 & & & & & & & 2 & 0.3 \\
\hline INANIM. & 11 & 6.5 & 3 & 2.4 & 14 & 7.0 & 13 & 15.1 & 2 & 2.8 & 43 & 6.7 \\
\hline NONE & 1 & 2.2 & & & 19 & 9.4 & 3 & 3.5 & 3 & 4.2 & 26 & 4.0 \\
\hline Total & 169 & & 125 & & 201 & & 86 & & 73 & & 654 & \\
\hline 8 & & 25.8 & & 19.1 & & 30.7 & & 13.1 & & 11.2 & & \\
\hline
\end{tabular}

In the tables where "Writings" are divided, "Wisdom" covers Psalms, Job, and Proverbs, whereas "Other" includes Ruth, Canticles, Ecclesiastes, Lamentations, Esther, Daniel, Ezra, Nehemiah, and the two Chronicles.

In the wisdom literature we find the literal meaning eight times out of a total of eighty-six. This is the lowest ratio, or about 9.3 percent. In the Pentateuch the ratio is 24.8 percent. Table 7 indicates that the greatest variation in distribution is found when weapons or cultic objects are the object of the verb. of thirty-four passages having weapons or instruments as objects twenty are found in the Early Prophets, or close to 59 percent. The distribution of the metaphoric usages is less variable than the literal, as table 6 clearly indicated. The 
Pentateuch has by far the highest ratio. Ninety-three out of a total of 169 occurrences in the Pentateuch involve metaphoric usage or 55 percent, whereas the Early Prophets have only twenty-five out of 125 , or 20 percent, and the Writings outside of the Wisdom seventeen out of seventythree, or 23.3 percent. The highest ratio outside of the Pentateuch is in the wisdom literature, forty-five out of a total of eighty-six, or 52.3 percent. The OT average is 40.4 percent.

As we analyze the metaphoric use further (table 8), we find an interesting similarity between the Pentateuch and the Later Prophets with 35.2 and 31.8 percent of the metaphoric uses respectively. Two types of expressions are especially noticeable, nāśa $\bar{a}^{2}$ eyes and $n \bar{a} \bar{s}^{\supset}+\sin$ and wrongdoing, which are used with remarkably similar frequency in these two divisions of the Bible. This similarity in frequency is, however, more related to the demands of the contents than the age of the document. It is also a fact that the messages of the prophets were strongly influenced by the Pentateuch, and they constantly appealed to the people to "return" to their religious foundation. Therefore, the similarity between theses two sections of the Bible is rather to be expected on the basis of common concerns of the authors. 
TABLE 7

DISTRIBUTION OF LITERAL USAGE IN THE OT

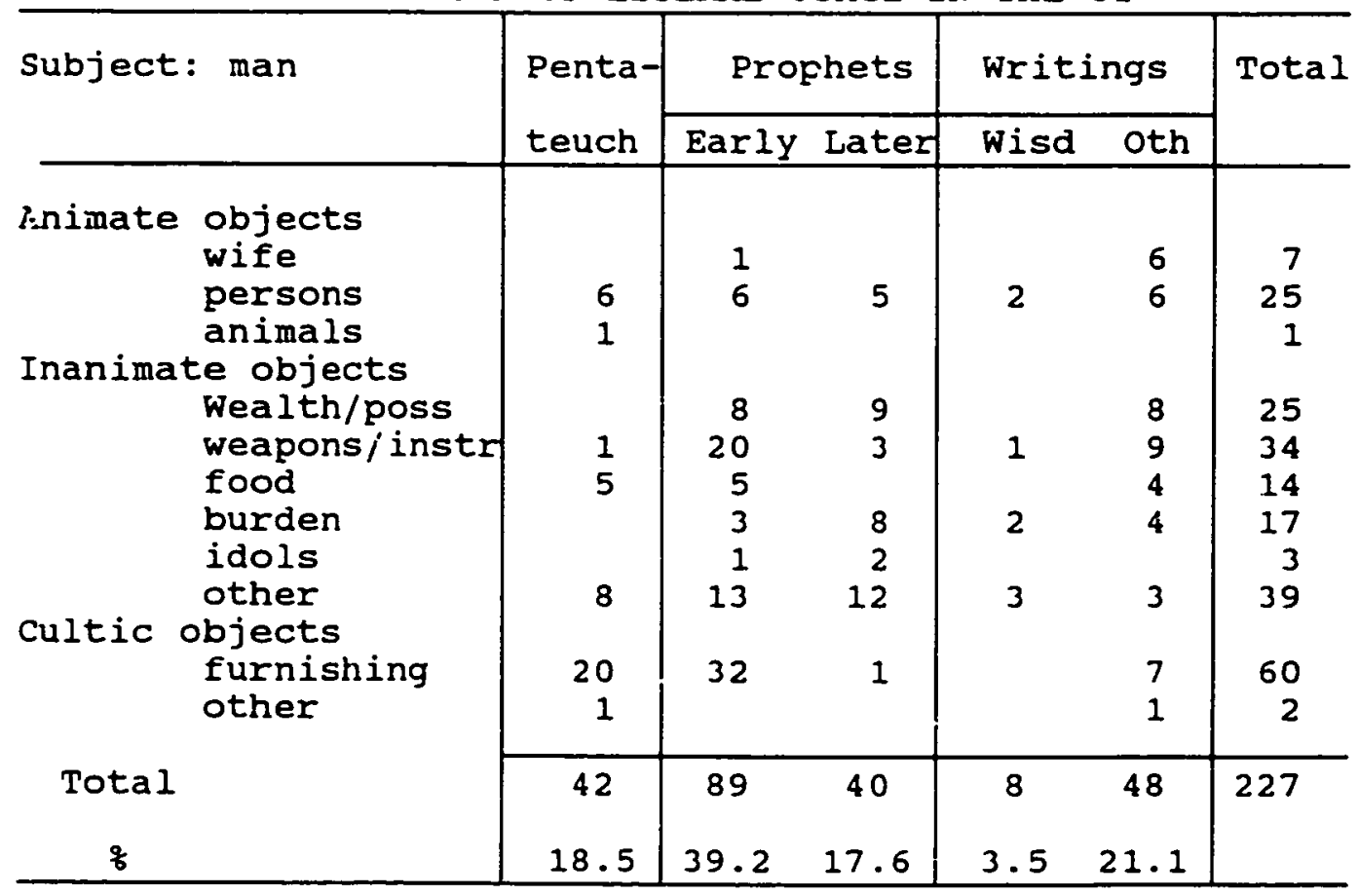


TABLE 8

DISTRIBUTION OF METAPHORIC USAGE IN THE OT (Subject: Man)

\begin{tabular}{|c|c|c|c|c|c|c|}
\hline \multirow{2}{*}{ object: } & \multirow{2}{*}{$\begin{array}{l}\text { Penta- } \\
\text { teuch }\end{array}$} & \multicolumn{2}{|c|}{ Prophets } & \multicolumn{2}{|c|}{ Writings } & \multirow[t]{2}{*}{ Total } \\
\hline & & Early & Later & Wisd & oth & \\
\hline $\begin{array}{l}\text { Body parts } \\
\text { soul/heart } \\
\text { voice } \\
\text { eyes } \\
\text { face/head } \\
\text { hand } \\
\text { feet } \\
\text { Persons } \\
\text { sin/wrongdoing } \\
\text { sins } \\
\text { judgm. etc } \\
\text { other objects } \\
\text { name } \\
\text { covenant } \\
\text { report } \\
\text { lament } \\
\text { responsib } \\
\text { parable } \\
\text { favor } \\
\text { other }\end{array}$ & $\begin{array}{r}1 \\
4 \\
18 \\
8 \\
1 \\
1 \\
10 \\
27 \\
6 \\
4 \\
1 \\
2 \\
7 \\
3\end{array}$ & $\begin{array}{l}8 \\
6 \\
7 \\
2\end{array}$ & $\begin{array}{r}3 \\
4 \\
22 \\
4 \\
\\
1 \\
29\end{array}$ & $\begin{array}{l}4 \\
1 \\
4 \\
4 \\
4 \\
3 \\
7\end{array}$ & $\begin{array}{l}1 \\
1 \\
3 \\
1 \\
1 \\
2\end{array}$ & $\begin{array}{r}9 \\
18 \\
53 \\
24 \\
8 \\
1 \\
16 \\
\\
65 \\
6 \\
4 \\
2 \\
1 \\
11 \\
2 \\
7 \\
4 \\
33\end{array}$ \\
\hline$\underset{q}{\text { Total }}$ & $\begin{array}{c}93 \\
35.2\end{array}$ & $\begin{array}{l}25 \\
9.5\end{array}$ & $\begin{array}{c}84 \\
31.8\end{array}$ & $\begin{array}{l}45 \\
17\end{array}$ & $\begin{array}{l}17 \\
6.4\end{array}$ & 264 \\
\hline
\end{tabular}

God as Subject

God is the subject of nāsia $\bar{a}^{2}$ eighty-six times in the OT, or some 13 percent of the total. All of these occurrences are metaphoric. More than half of them, forty-four, are in the Later Prophets. It is also interesting to notice that the Pentateuch has only 
TABLE 9

DISTRIBUTION OF METAPHORIC USAGE IN THE OT (Subject: God)

\begin{tabular}{|c|c|c|c|c|c|c|}
\hline & \multirow{2}{*}{$\begin{array}{l}\text { Penta- } \\
\text { teuch }\end{array}$} & \multicolumn{2}{|c|}{ Prophets } & \multicolumn{2}{|c|}{ Writings } & \multirow[t]{2}{*}{ Total } \\
\hline & & Early & Later & Wisd & oth & \\
\hline $\begin{array}{c}\text { Animate objects } \\
\text { persons } \\
\text { animals } \\
\text { Body parts } \\
\text { face } \\
\text { hands } \\
\text { 'wings' } \\
\text { Inanimate obj } \\
\text { sins } \\
\text { place } \\
\text { Other objects }\end{array}$ & $\begin{array}{l}2 \\
3\end{array}$ & $\begin{array}{l}1 \\
3\end{array}$ & $\begin{array}{r}11 \\
1 \\
2 \\
12 \\
3 \\
5 \\
10\end{array}$ & $\begin{array}{l}1 \\
2 \\
5 \\
2\end{array}$ & $i$ & $\begin{array}{r}26 \\
1 \\
5 \\
18 \\
3 \\
\\
15 \\
2 \\
16\end{array}$ \\
\hline $\begin{array}{c}\text { Total } \\
\frac{6}{6}\end{array}$ & $\begin{array}{c}17 \\
19.8\end{array}$ & $\begin{array}{c}6 \\
6.9 \\
\end{array}$ & $\begin{array}{c}44 \\
51.2 \\
\end{array}$ & $\begin{array}{c}17 \\
19.8 \\
\end{array}$ & $\begin{array}{r}2 \\
2.3 \\
\end{array}$ & 86 \\
\hline
\end{tabular}

seventeen occurrences, or the same as the Wisdom literature. When it comes to the combination "God $+n s^{2}+$ sin and/or wrongdoing" we find surprisingly that the Pentateuch uses it only four times, whereas it is found five times in the Later Prophets and five times in the Wisdom literature.

Other Subjects

The frequency of other subjects with nāsa' is very low (see table 10). Animals are the subject eight times, five of which are in the Pentateuch. In three of these 
TABLE 10

\section{DISTRIBUTION OF METAPHORIC USAGE IN THE OT (Subject: Non-human) \\ Animals}

\begin{tabular}{|c|c|c|c|c|c|c|}
\hline \multirow[b]{2}{*}{ object } & \multirow{2}{*}{$\begin{array}{l}\text { Penta- } \\
\text { teuch }\end{array}$} & \multicolumn{2}{|c|}{ Prophets } & \multicolumn{2}{|c|}{ Writings } & \multirow[t]{2}{*}{ Total } \\
\hline & & Early & Later & wisd & oth & \\
\hline $\begin{array}{l}\text { Literal } \\
\text { Metaphoric } \\
\text { sins } \\
\text { other }\end{array}$ & $\begin{array}{l}3 \\
1 \\
1\end{array}$ & $\begin{array}{l}1 \\
1\end{array}$ & & & 1 & $\begin{array}{l}5 \\
1 \\
2\end{array}$ \\
\hline$\underset{8}{\text { Total }}$ & $\begin{array}{c}5 \\
62.5\end{array}$ & $\begin{array}{r}2 \\
25\end{array}$ & & & $\begin{array}{c}1 \\
12.5\end{array}$ & 8 \\
\hline
\end{tabular}

Inanimate

\begin{tabular}{|c|c|c|c|c|c|c|}
\hline$\underset{6}{\text { Total }}$ & $\begin{array}{l}11 \\
25\end{array}$ & ${ }^{3} .8$ & $\begin{array}{c}15 \\
34.1\end{array}$ & $\begin{array}{c}13 \\
29.5\end{array}$ & $\begin{array}{c}2 \\
4.5\end{array}$ & 44 \\
\hline \multicolumn{7}{|c|}{ None } \\
\hline$\underset{\frac{q}{q}}{\text { Total }}$ & $\begin{array}{c}1 \\
3.8\end{array}$ & & $\begin{array}{c}19 \\
73.1\end{array}$ & $\begin{array}{c}3 \\
11.5\end{array}$ & $\begin{array}{c}3 \\
11.5\end{array}$ & 26 \\
\hline
\end{tabular}


the animals are presented as carrying literal loads; ${ }^{1}$ in one passage the verb is used reflexively about a lion rising up, ${ }^{2}$ and in one the goat of Azazel is represented as carrying the iniquities of the people into the desert. ${ }^{3}$ Inanimate subjects are found forty-four times in the CT, eleven of which are in the Pentateuch. They are mostly elements of nature (e.g., wind or water), which maybe supporting boats ${ }^{+}$or transporting chaff $f^{5}$ and grasshoppers. ${ }^{6}$ Twenty-six times the verb is used without any specified subject. The majority of those, or nineteen, are found in the Later Prophets, with only one in the Pentateuch.' Apart from variations as to the subject, none of these passages reveal any differences in morphology, syntax, or word associations.

Summary

The root nāsā is common semitic. In spite of different developments of the s-phoneme in the various

'Camels carrying spices in Gen $37: 25$; asses and donkeys carrying grain and bread in Gen 45:23.

${ }^{2}$ Num $23: 24$.

${ }^{3}$ Lev $16: 22$.

the rising water in Gen $7: 17$.

The wind in Dan $2: 35$.

The wind in Exod 10:13, 19.

'In Gen $4: 7$ where it is in the context of cain's wrongdoing. 
languages, there is, however, no evidence of any interchange between the various $\mathbf{s}$-phonemes in the languages under investigation, as far as this root is concerned. The contextual evidence indicates, rather, only one root nāśa $\bar{a}^{2}$, with the idea of a sustained upward/ onward movement, which is quite adjustible to the needs of a given context.

The nominal forms predominantly indicate something that needs to be upheld, whether it is a real burden that must be carried, a message brought, a position held, 'social status,' or an attitude of prayerfulness. The usage of both the nominal and verbal forms seems to indicate that the verbal root $n \bar{a} \bar{s}^{\supset}$ and its derivatives convey the idea of a sustained upward-onward movement, which may have either a positive or negative effect, depending on the context in which they are found. The words themselves are quite neutral. Their distribution and use is quite universal and non-technical. No significant differences are noticeable in their distribution and basic meaning through the various parts of the old Testament, except those that can be expected due to variations in subject matter. This survey of the distribution and usage of $n \dot{s}^{\supset}$ in the OT also indicates that the Pentateuchal usage is quite similar to that in the OT in general. It seems therefore reasonable to 
conclude that a study of its use in the Pentateuch will give a fair picture of its use in the MT in general.

\section{The Pentateuch in Particular}

Morphology

Table 4 above indicated a surprisingly even distribution of the verbal forms throughout the entire OT corpus. One thing was quite noticeable, however: the disproportionate distribution of infinitives and participles in the Pentateuch compared to the rest of the OT. Out of fifty infinitives in the OT, twenty-four are found in the Pentateuch, whereas only fourteen participles out of a total of ninety-five are found there, as can be seen in table 11.

sixteen of the infinitives have a $l^{e}$ prefix,! which twice expresses a statement 'with respect to' a particular condition, ${ }^{2}$ once functions similar to the sign of the infinitive in English "to" ${ }^{3}$ once it expresses a result, ${ }^{+}$while in the remaining passages it implies a

${ }^{1}$ Gen $36: 7 ; 45: 27 ; 46: 5 ; \operatorname{Exod} 25: 14,27 ; 30: 4 ; 37: 5$, 14 ，15, 27; 38:7; Lev 10:17; Num 4:15; 11:14; 18:22; Deut $10: 8$.

'The land's inability to support a large herd (Gen $36: 7)$ and Moses' expressed inability to take care of the needs of the people (Num 11:14).

${ }^{3} \mathrm{Num} 4: 15$ about the things in the sanctuary which the sons of Kohath were to carry.

'In Num 18:22 about the Israelites' not coming near the tent of meeting "so that" they would not incur guilt 
TAELE 11

DISTRIBUTION OF VERBAL ASPECTS OF $N \bar{S}^{\supset}$ IN THE PENTATEUCH

\begin{tabular}{|c|c|c|c|c|c|c|c|c|c|c|c|c|}
\hline \multirow[b]{2}{*}{ QAL } & \multicolumn{2}{|c|}{ Gen } & \multicolumn{2}{|c|}{ Exod } & \multicolumn{2}{|c|}{ Lev } & \multicolumn{2}{|c|}{ Num } & \multicolumn{2}{|c|}{ Deut } & \multicolumn{2}{|c|}{ Total } \\
\hline & $\#$ & 8 & $F$ & $q$ & $\neq$ & 8 & $\neq$ & $q$ & * & $q$ & $f$ & 8 \\
\hline $\begin{array}{l}\text { Infin } \\
\text { Perf } \\
\text { Imperf } \\
\text { Part. } \\
\text { Imp.t }\end{array}$ & $\begin{array}{r}6 \\
5 \\
27 \\
3 \\
6\end{array}$ & $\begin{array}{r}12.8 \\
10.6 \\
57.4 \\
6.4 \\
12.8\end{array}$ & $\begin{array}{r}9 \\
10 \\
11 \\
1 \\
1\end{array}$ & $\begin{array}{r}28.1 \\
31.3 \\
34.4 \\
3.1 \\
3.1\end{array}$ & $\begin{array}{r}1 \\
5 \\
10 \\
4 \\
1\end{array}$ & $\begin{array}{r}4.8 \\
23.8 \\
47.6 \\
19.2 \\
4.8\end{array}$ & $\begin{array}{r}5 \\
8 \\
23 \\
3 \\
5\end{array}$ & $\begin{array}{r}6.8 \\
15.9 \\
52.3 \\
6.8 \\
18.2\end{array}$ & $\begin{array}{r}3 \\
1 \\
12 \\
3 \\
1\end{array}$ & $\begin{array}{r}15.0 \\
5.0 \\
60.0 \\
15.0 \\
5.0\end{array}$ & $\begin{array}{l}24 \\
29 \\
83 \\
14 \\
14\end{array}$ & $\begin{array}{r}14.2 \\
17.2 \\
49.0 \\
8.3 \\
8.3\end{array}$ \\
\hline Total & 47 & & 32 & & 21 & & 44 & & 20 & & 164 & \\
\hline
\end{tabular}

purpose.' One infinitive has prefixed min of comparison, ${ }^{2}$ one a prefixed $b^{e}$ indicating the time "when," four times the infinitive is in the construct state," and twice in the absolute form." The reason for the heavy concentration of infinitives in the Pentateuch appears, however, to be purely pragmatic-contextual rather than stylistic.

and die.

${ }^{1}$ Gen $45: 27 ; 46: 5$; Exod $25: 14,27 ; 30: 4 ; 37: 5,14$, 15, 27; 38:7; Lev 10:17; Deut 10:8. Cf. Gesenius, 348; and Choon L. Seow, A Grammar for Biblical Hebrew (Nashville: Abingdon Press, 1987), 190.

${ }^{2}$ Gen $4: 13$. See Seow, 41 .

${ }^{3}$ Exod 27:7. See Seow, 190, 191 .

4Gen $4: 7 ; 44: 1$. Deut 1:9; 14:24.

${ }^{5}$ Num $4: 2,22$. 
As to the participles, seven are masculine singular,' two of which are parallel passages where the

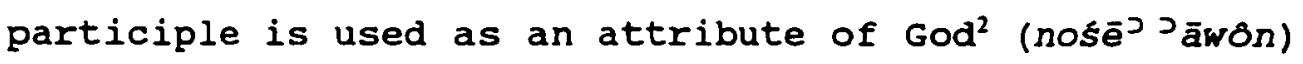

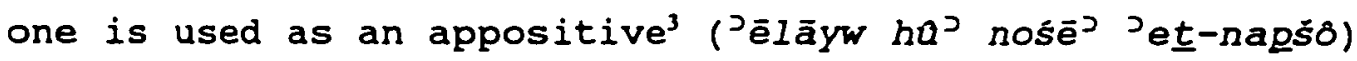
while the remaining four are used nominally ("the one who") about someone carrying a corpse. Six times the participle is used in the masculine plural and once in the feminine plurals, all of which are descriptive in nature indicating an ongoing action. The uneven distribution of the participles appears to correspond to the needs of the context rather than being the result of stylistics or difference in time.

As we consider the distribution of the verb in the Pentateuch (see table 11), we find that the book of Exodus is somewhat different from the others, with its almost equal concentration of infinitives, perfects, and imperfects, or about 30 percent each, whereas in Genesis, Leviticus, Numbers, and Deuteronomy the imperfect makes up Deut 24:15.

${ }^{1}$ Exod $34: 7$; Lev $11: 25,28,40 ; 15: 10 ;$ Num $14: 18 ;$ and

${ }^{2}$ Exod $34: 7$ and Num $14: 18$.

${ }^{3}$ Deut 24:15. See Frank R. Blake, A Resurvey of Hebrew Tenses (Roma: Pontificium Institutum Biblicum, 1951), 29 .

'Camels in Gen 37:25; asses in Gen 45:23; certain groups of Levites in Num 10:17, 21 and Deut 3::s, 25.

${ }^{5} \mathrm{About}$ she-asses in Gen 45:23. 
about 50 percent or more of the occurrences, and the infinitive only 5 to 15 percent. There is, however, no indication that these are anything but the result of contextual needs, for infinitives per se do not appear to occur any less frequently in Leviticus than the rest of the Pentateuch, so it is a mere coincidence that only one of these happens to be derived from the root nāśa examination of various morphological forms of randomly selected verbal roots indicates that their distribution in the books of the Pentateuch is dependent on the subject matter rather than difference in style (see table 12). Large portions of Exodus--especially from chapter 20 on--consist mainly of instructions about general or specific actions which in Hebrew frequently involve a combination of imperfects and perfects with wawconsecutive.' When instructions include purposive statements the use of infinitives is quite natural. The books of Genesis, Numbers, and Deuteronomy, on the other hand, consist mostly of past narratives which demand a higher proportion of imperfects with waw-consecutive. ${ }^{2}$

\footnotetext{
'Gesenius talks about 'frequentative perfect consecutive,' "which is frequently employed with a certain emphasis to introduce the apodosis after sentences . . . which contain a condition, a reason, or a statement of time. Such an apodosis. . . may represent either future events, or commands and wishes, or even events which have been often repeated in the past." Gesenius, 5112.

${ }^{2}$ Gesenius states, "The imperfect with waw consecutive serves to express actions, events, or states,
} 
TABLE 12

DISTRIBUTION OF VERBAL FORMS

\begin{tabular}{|c|c|c|c|c|c|}
\hline \multicolumn{6}{|c|}{ Infinitive } \\
\hline & $J_{m r}$ & $\bar{s} m^{c}$ & $q r b$ & $z b h$ & $I q h$ \\
\hline Gen & 77 & 6 & & $1^{\circ}$ & 7 \\
\hline Ex & 51 & 6 & 2 & & \\
\hline Lev & 51 & 1 & 8 & 1 & \\
\hline Num & 85 & 6 & 7 & & \\
\hline Deut & 41 & 13 & 1 & 1 & 7 \\
\hline
\end{tabular}

Perfect

\begin{tabular}{lrrrrr}
\hline Gen & 47 & 20 & 2 & & 21 \\
Ex & 34 & 16 & 6 & 4 & 24 \\
Lev & 12 & 1 & 30 & 1 & 23 \\
Num & 32 & 8 & 21 & & 24 \\
Deut & 52 & 22 & 5 & 3 & 18 \\
\hline
\end{tabular}

Imperfect

\begin{tabular}{lrrrrr}
\hline Gen & 465 & 17 & 3 & 2 & 84 \\
Ex & 194 & 22 & 5 & 10 & 42 \\
Lev & 15 & 4 & 49 & 5 & 28 \\
Num & 124 & 12 & 25 & 1 & 33 \\
Deut & 45 & 39 & 6 & 7 & 19 \\
\hline
\end{tabular}

Another morphological feature of interest is the distribution of 'person,' 'gender,' and 'number' in the different aspects combined with the use of wawconsecutive. The question is whether there is any apparent relationship between morphological forms and fixed expressions.

which are to be regarded as the temporal or logical sequel of actions, events, or states mentioned immediately before. The imperfect consecutive is used in this way most frequently as the narrative tense." Gesenius, S 111a. 
Table 13 shows great flexibility in tris respect in the use of nāsāa $\bar{a}^{2}$. Two things are noted: the high proportion of the waw-consecutive forms in Genesis and their total absence in Deuteronomy. An examination of these passages does not, however, reveal any significance relating to this fact. It appears rather to be a coincidental contextual feature, for waw-consecutive forms, in general, appear to be fairly evenly distributed throughout the Pentateichal narratives (see table 14).

TABLE 13

MORPHOLOGICAL DISTRIBUTION (Finite Forms)

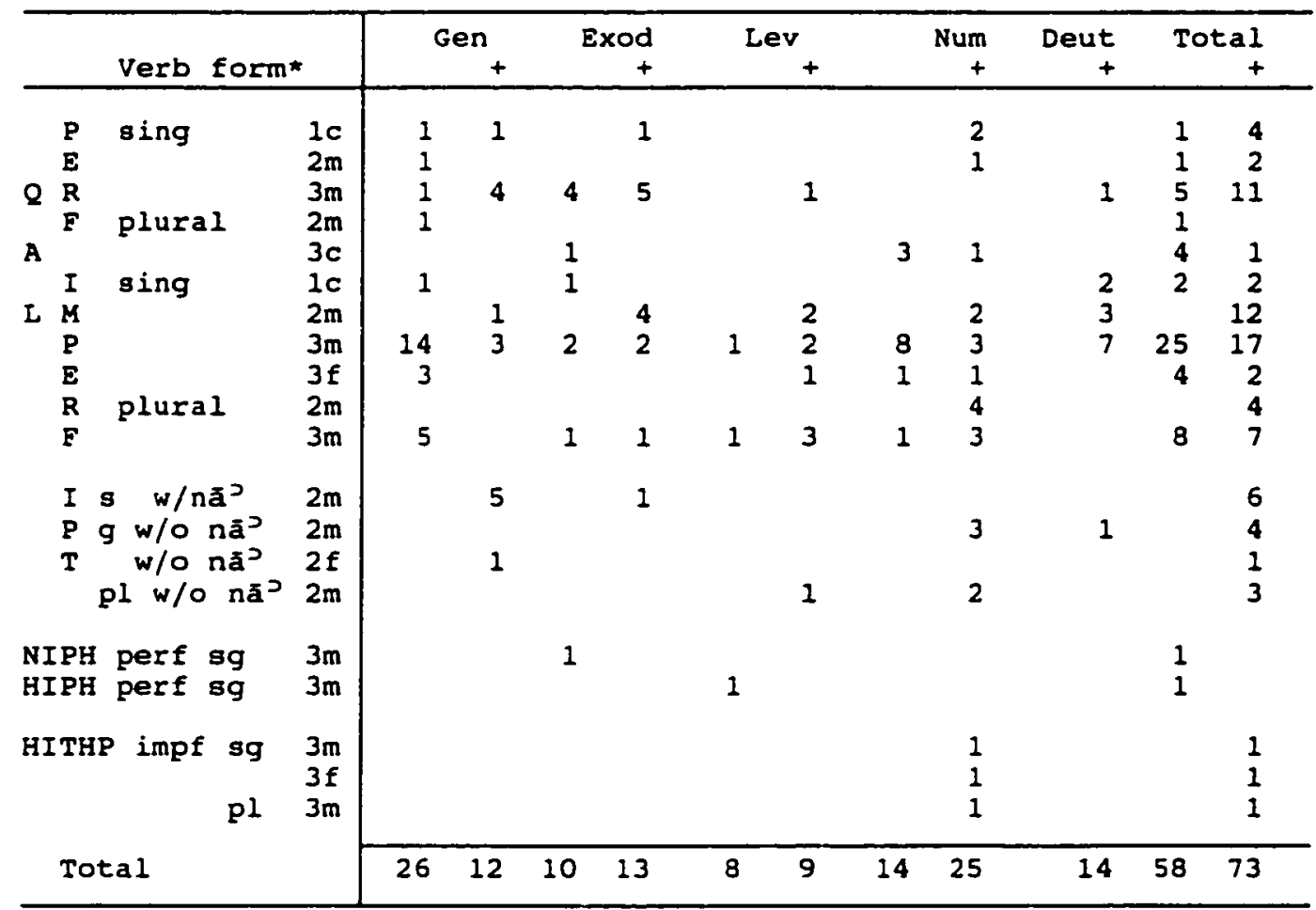

* Note: The plus-sign $(+)$ indicates forms with waw consecutive. 
TABLE 14

DISTRIBUTION OF WAW-CONSECUTIVE FORMS

IN THE PENTATEUCH

\begin{tabular}{l|rrrrrrrrrr}
\hline \multirow{2}{*}{} & \multicolumn{2}{|c}{${ }^{2} m r$} & \multicolumn{2}{c}{$\bar{s}^{c}$} & \multicolumn{2}{c}{$q r b$} & \multicolumn{2}{c}{$z b h$} & \multicolumn{2}{c}{ Iqh! } \\
\cline { 2 - 11 } & Perf & Impf & Perf & Impf & Perf & Impf & Perf & Impf & Perf & Impf \\
\hline Gen & 11 & 394 & 0 & 12 & 0 & 1 & 0 & 2 & 11 & 68 \\
Exod & 13 & 144 & 2 & 6 & 3 & 0 & 3 & 2 & 22 & 23 \\
Lev & 10 & 12 & 1 & 0 & 22 & 13 & 1 & 0 & 22 & 10 \\
Num & 18 & 103 & 4 & 4 & 20 & 13 & 0 & 1 & 14 & 23 \\
Deut & 26 & 20 & 9 & 6 & 1 & 4 & 0 & 0 & 10 & 5 \\
\hline
\end{tabular}

Note: The numbers in the perfect may not be quite accurate as they include some waw conjunctions.

The finite forms occur altogether 131 times, thus making up 77.5 percent of the total number. They occur most frequently in the third person, 89 times, or 67.9 percent of the finite forms. Of these, 68 are in the singular (61 are masculine, and 7 feminine); 21 are plural (16 masculine and 5 common). Second person occurs 33 times, 14 of which are imperatives, or 25.2 percent. Twenty-five of these are singular, with all but 1 being masculine. All of the plural forms are masculine. First person is found 9 times, or in 6.9 percent of the finite forms, all of them in the singular.

Finally we have the non-finite forms in table 15. They occur thirty-eight times, and represent the remaining 22.5 percent. As we evaluate the morphological evidence, we find that no single morphological feature can be 
109

associated with any particular meaning of the root. The great variety just corroborates its flexibility.

TABLE 15

MORPHOLOGICAL DISTRIBUTION

(Non-finite Forms)

\begin{tabular}{|c|c|c|c|c|c|c|c|c|}
\hline \multicolumn{3}{|l|}{ QAL } & Gen & Ex & Lev & Num & Deut & Total \\
\hline $\begin{array}{l}\text { Parti- } \\
\text { ciple }\end{array}$ & $\begin{array}{l}\text { Sing } \\
\text { Plur }\end{array}$ & $\begin{array}{l}\text { masc } \\
\text { masc } \\
\text { fem }\end{array}$ & $\begin{array}{l}2 \\
1\end{array}$ & 1 & 4 & $\begin{array}{l}1 \\
2\end{array}$ & $\frac{1}{2}$ & $\begin{array}{l}7 \\
6 \\
1\end{array}$ \\
\hline Infin & $\begin{array}{l}w / p r \\
w / 0 F\end{array}$ & $\begin{array}{l}\text { efix } \\
\text { refix }\end{array}$ & $\begin{array}{l}4 \\
2\end{array}$ & 9 & 1 & $\begin{array}{l}3 \\
2\end{array}$ & $\begin{array}{l}1 \\
2\end{array}$ & $\begin{array}{r}18 \\
6\end{array}$ \\
\hline Total & & & 9 & 10 & 5 & 8 & 6 & 38 \\
\hline
\end{tabular}

Syntax

Great flexibility is also found in the way nāsáa

links up with its direct object. In this section we examine these more closely in order to determine if there are any particular meanings related to specific syntactical constructions, or if certain constructions imply a technical usage or meaning.

\section{object Linkage}

The verb is used transitively more than 94 percent of the time. Sometimes it has an external link with its 
object, e.g., the object indicator or a preposition; but frequently it is introduced without a preposition. of the linkages the object indicator ' ${ }^{2} \bar{e} \underline{t}$ is the most frequent, as table 16 indicates. It is used sixty-eight times, or 40.2 percent of the time. In the Pentateuch the object has no prepositional linkage in sixty instances or 35.5 percent of the occurrences. The verb seems to have little, if any, preference for a particular preposition. Again, the context appears to be the determining factor. There are apparently no fixed constructions being used in a technical sense. Ten times, or in 5.9 percent of the occurrences, the verb has no specified direct object.

TABLE 16

SYNTACTICAL DISTRIBUTION

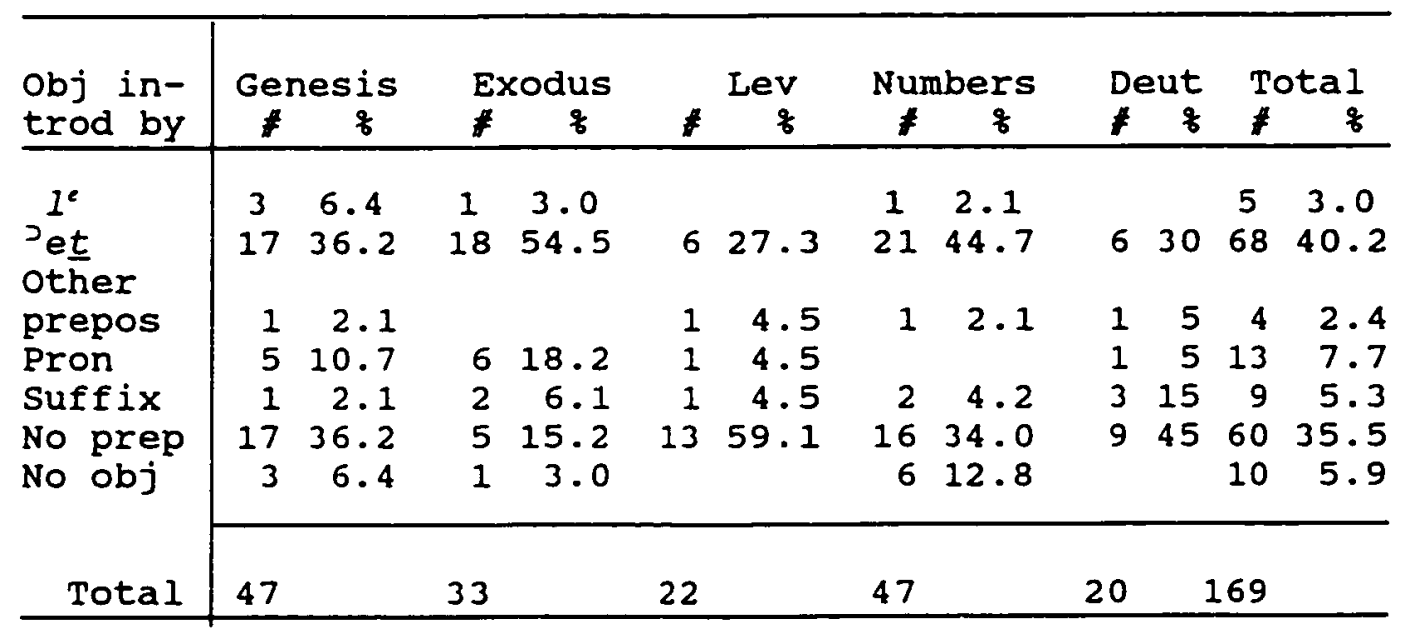

'Prepositions are only used nine times: $I^{e}$ five times, min three times, and $b^{e}$ once. 
Subject-object Linkage

Table 17 further analyzes how the verb is syntactically linked to its direct object. According to this table, divine beings are the subject seventeen times, or in about 10 percent of the cases. Man is the subject 135 times, or about 80 percent of the time, and other, or no, subjects make up the remaining 10 percent (seventeen times). Interestingly, God is never the subject of nāsāj in Leviticus, even though he is the subject in the other four books of the Pentateuch. Apart from the scapegoat in Lev 16 'man' is the only subject of nāsaj' in Leviticus.

TABLE 17

SUBJECT-OBJECT LINKAGE

\begin{tabular}{|c|c|c|c|c|c|c|c|c|c|c|c|c|c|c|}
\hline \multirow{2}{*}{$\begin{array}{l}\text { Subject: } \\
\text { Objects }\end{array}$} & \multicolumn{4}{|c|}{ God/Div.beings } & \multicolumn{5}{|c|}{ Man } & \multicolumn{4}{|c|}{ Other } & \multirow[b]{2}{*}{ Total } \\
\hline & Gen & Ex & Num & Dt & Gen & Ex & Lev & Num & Dt & Gen & Ex & Lev & Num & \\
\hline $\begin{array}{l}\text { Body } \\
\text { parts } \\
\text { Personst } \\
\text { Things } \\
\text { Wrongs } \\
\text { No obj }\end{array}$ & $\begin{array}{l}1 \\
2\end{array}$ & $\begin{array}{l}1 \\
2\end{array}$ & $\begin{array}{l}1 \\
1 \\
1\end{array}$ & 1 & $\begin{array}{r}8 \\
10 \\
8 \\
2 \\
2 \\
1 \\
1 \\
1 \\
2\end{array}$ & $\begin{array}{r}1 \\
1 \\
14 \\
4 \\
2 \\
1\end{array}$ & $\begin{array}{c}1 \\
1 \\
2 \\
4 \\
13\end{array}$ & $\begin{array}{l}2 \\
8 \\
1 \\
7 \\
9 \\
6 \\
4 \\
4\end{array}$ & $\begin{array}{l}1 \\
2 \\
2 \\
1 \\
5 \\
3\end{array}$ & $\begin{array}{l}6 \\
2\end{array}$ & $\begin{array}{l}1 \\
2 \\
2\end{array}$ & 1 & 2 & $\begin{array}{l}15 \\
14 \\
23 \\
13 \\
42 \\
15 \\
13 \\
24 \\
10\end{array}$ \\
\hline Total & 3 & 5 & 4 & 5 & 35 & 23 & 21 & 41 & 15 & 9 & 5 & 1 & 2 & 169 \\
\hline
\end{tabular}

Note: The plus (+) and minus (-) signs indicate the presence or absence of prepositions, object indicator, or independent personal pronouns introducing the object. The category "Body parta" covers all parta or functions of the subject's own body affected by the verb. 
In twenty-nine instances we find 'body-parts' as the object, 'persons' in thirty-six instances, 'wrongs' in thirty-seven, and 'things' or other objects in fiftyseven, and no spacific object in ten instances.

\section{Positional Indications}

Positional indicators point out the direction of the verbal action, whether it implies a movement or a localized position. Six such morphs were used with the root $n \hat{s}^{2}$ in the Pentateuch, altogether forty-three times: five prepositions and the directional -ăh (see table 18). An analysis of these usages indicated considerable fluidity. Indeed, no fixed patterns were detected. Apart from the directional $-\bar{a} h$ and the preposition ${ }^{2} e l$ the indication was quite ambiguous and had ultimately to be determined by the immediate context or the general flow of the narrative. That was aiso the main indicator in the remaining $120+$ passages where there were no directional morphs present with $n \dot{s}^{\supset}$. Significantly, it was also noted that the use of the prepositions was most frequently used in texts indicating movement. This appears to support the contention that the root may include some movement in its semantic range, without it being its basic meaning, and it must, therefore, often be drawn out by some morphs indicating the movement. 
As we survey the syntactical evidence, we find no indication of any particular structures being associated with specific meanings of the root. Again, this confirms earlier findings about the great flexibility in the general meaning and usage of the root nāśà

TABLE 18

POSITION INDICATORS

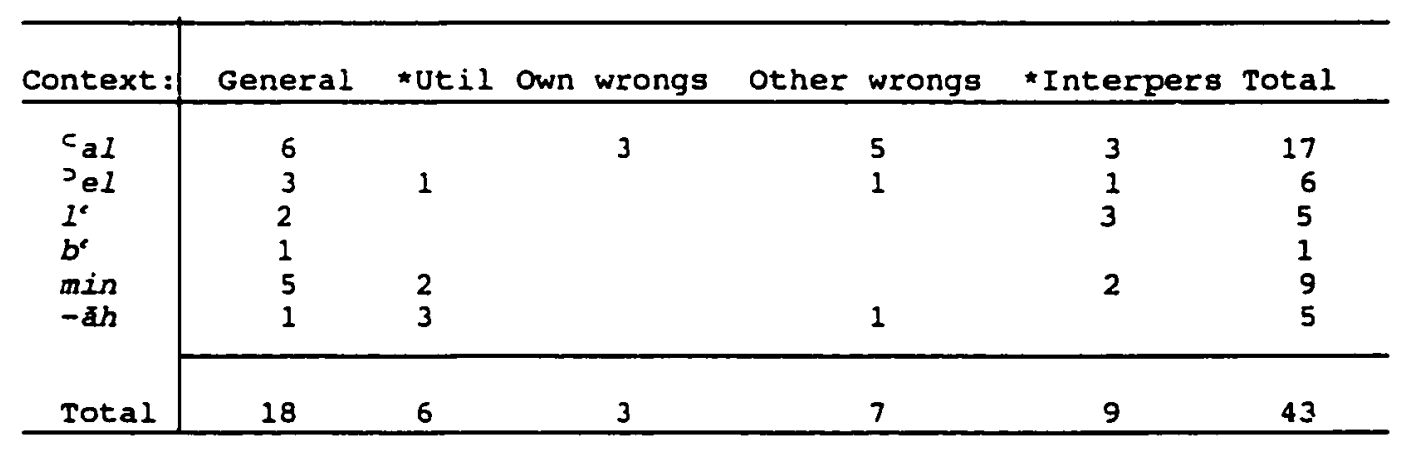

*Util = Utilization; *Interpers = Interpersonal relations

Synonyms and Parallels

Throughout the OT there are several synonyms for the root $n \bar{a} \bar{s} \bar{a}^{\prime}$. Fabry' mentions the main ones as 'āmas "lift," sābal "carry," lāqạ̣ "take," nāṭal "load," and yābal (hiph) "bring." of these only the first three are found within the Pentateuch: ' $\bar{a}$ mas and sābal occur once each as synonyms of nāsāj ; lāqặ occurs several times, but very seldom does its meaning overlap that of $n \bar{a} \mathbf{s} \bar{a}^{2}$. Actually the synonyms can be classified into four groups

\footnotetext{
'Heinz-Josef Fabry, "nāśā'," TWAT (1986), 5:627.
} 
which agree with four different areas of usages of nāsa': literal, metaphoric, idiomatic, and sequels.' only two clear antonyms were noted in the Pentateuch: nāpal

"fall," and šăkxab "lie down."

\section{Literal Usage}

1. Cämas: "Each man loaded (wayyacamos) his donkey." "4

2. sābal: "He bowed his shoulder to bear (1isbol) [burdens]. "15

\section{3. läqah: "Now Rachel had taken (lāquhāh) the} household idols." ${ }^{6}$

Besides these others also are used synonymously in a literal sense such as ram, (hiph) "raise, lift up,"

\footnotetext{
'Sequels are not synonyms in the real sense of the word. Rather, as used in this research, they are verbal expressions which immediately follow a statement of utilization of an object indicating the purpose of that action.

${ }^{2}$ Gen $4: 6$.

${ }^{3}$ Num $23: 24$.

Gen 44:13. Cf. Gen 42:26," So they loaded (wayyis $\hat{s}^{\supset}$ ) their donkeys."

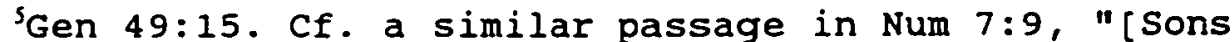
of Kohath] . . . theirs was the service of the holy [which] they carried (yiśsa'o $a$ ) on the shoulder."

${ }^{6} \mathrm{Gen} 31: 34$. Cf. Num 16:15 where the verb is used in a similar context implying stealing: "I have not taken

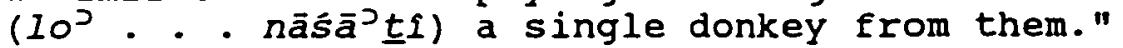


țācan "load," yāṣā’ (hiph) "make . . go out," nāgāo

"touch," and $e_{\bar{a}}$ lah (hiph) "bring up, lead up."

4. ram (hiph): "And the water increased and

lifted up (wayyis ${ }^{3}$ ) the ark, so that it rose [or: was

high] (wattārām) above the earth."l

5. ța $\bar{a}^{C} a n:$ "Do this: load (ța $\left.a^{c a} n\right)$ your beasts and go to the land of Canaan."2

6. yașă (hiph): "At the end of every third year you shall bring out (toṣ̂́ ${ }^{2}$ ) all the tithe."3

7. nāgac: "Whoever touches (hannogēac) their carcass. "14

8. Càlah (hiph): [Joseph said] "You shall carry (wha ${ }^{\text {ea }} 1$ ftem) my bones from here with you."s

Metaphoric Usage

In the metaphoric sense there are also several synonyms and word associations, e.g., nādaㅁ "urge,

'Gen $7: 17$.

${ }^{2}$ Gen $45: 17$. Cf. also $45: 23$ where the command is being fulfilled as Joseph sends his father "ten donkeys loaded (nos $1 \mathrm{~s}$ ) with the best things of Egypt."

${ }^{3}$ Deut $14: 28$. Cf. Deut $14: 24$, "If the distance is so great for you that you are not able to bring it ( $\hat{s}^{e J} \bar{e} \hat{b}$ ) [the tithe]. . . you shall exchange it."

${ }^{4}$ Lev 11:24. Cf. Lev 11:25, "Whoever picks up (hannos $\bar{e}^{\supset}$ ) any of their carcasses."

${ }^{5}$ Exod 13:19. Cf. a similar command by Jacob in Gen $47: 30$, "You shall carry me (an $\bar{s} \bar{a}^{2} \tan \{$ ) (referring to his bones] out of Egypt and bury me." 
prompt," šālạ̣ "let go, send," lāqạ̣ "take, seize," sālạ̣ "forgive," and kpr (piel) "appease, make amends."

1. nādaba: "And everyone whose heart stirred him $\left(n^{e} \bar{s}^{\top} \delta\right)$ and everyone whose spirit moved him (nād $\left.\underline{b} \underline{b} \bar{a} h\right) . " 2$

2. šălaḥ: "You shall serve your enemies whom the Lord shall send (Yešallẹ̣ennu) against you."

3. Iāqah: "He spread out his wings and caught them ( $y$ iqqāhēeha), he carried them ( $\left.y i \bar{s}^{3} \bar{a}^{\top} \bar{e} h a\right)$ on his pinions." 4

4. sālaḥ: Having referred to God as the nos $\bar{e}^{\supset}$ Jāwôn Moses pleads with him: "Pardon, I pray, the iniquity $\left(s^{e} l a h-n \bar{a}^{\supset}\right.$ lacaón) of this people. . just as you have forgiven [or: carried] (nāsā̃ tāh) this people from Egypt even until now."s

5. kpr (piel): "He gave it [the sin offering] to

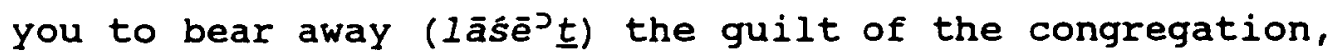
to make atonement ( $\left.1^{\circ} \underline{k} a p p e \bar{r}\right)$ for them before the Lord." 6

'Aloysius Fitzgerald, "MTNDBYM in 1QS" CBO, 36 (1974) : 498 suggests "a generous impulse."

${ }^{2}$ Exod $35: 21$.

${ }^{3}$ Deut 28:48. Cf. Deut 28:49, "The Lord will bring

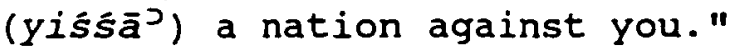

${ }^{4}$ Deut $32: 11$.

${ }^{5} \mathrm{Num} 14: 19$.

${ }^{6}$ LeV 10:17. 


\section{Idiomatic Usage}

For certain idiomatic expressions, the following synonyms are found:

$$
\text { 1. nāśā ro’s (referring to a census) = pāqad }:^{1}
$$

"Only the tribe of Levi you shall not number (10 tipgod),

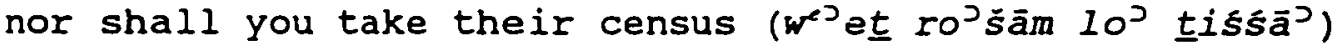
among the sons of Israel."2

2. nāŝă on the context:

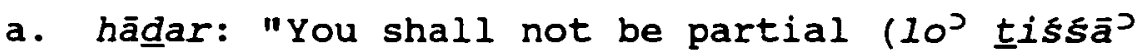
$\underline{p}^{e} n e$ ) to the poor nor defer (10 tehdar) to the great. "13 b. hānan: "A nation of fierce countenance who shall have no respect (10ว yiśsā pānim) for the old, nor show Eavor ( $10^{3}$ yăhon) to the young."4

c. māṣā haēn: "If I have found grace (māṣa $\bar{a}^{\supset} \underline{\underline{I}}$ hẹen) in your eyes." s

${ }^{1}$ Gunnel André has pointed out in his dissertation Determining the Destiny (Lund, Sweden: CWK Gleerup, 1980), 114 passim, that even though these expressions are very similar in meaning they are apparently not quite interchangeable. Pāqad can in most cases replace nāsás ro rós, but the reverse can only take place in certain positions. See especially p. 117 in André's book.

${ }^{2}$ Num 1:49. In some cases this expression may possibly be synonymous with the expression natan ro's "appoint a leader" in Num 14:4.

${ }^{3}$ Lev $19: 15$.

${ }^{4}$ Deut 28:50.

${ }^{5}$ Gen $33: 10$. Cf. a parallel passage in Gen $32: 21$ : "Perhaps he will accept me (yiśs̄à pānay)." 
d. rāṣāh: "You have received me favorably (wattirșēnf)."l

e. Jor (hiph): "The Lord make his face shine ( $\bar{a}^{\bar{a}} \bar{e} r$ yhwh pānāyw) on you. . . The Lord lift up his

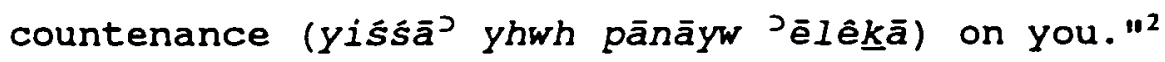

\section{Sequels}

Sequels indicate the immediate result of an action initiated by nāśa ${ }^{2}$. The following are found in the Pentateuch:

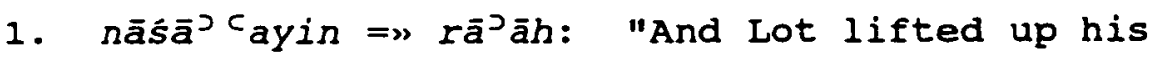

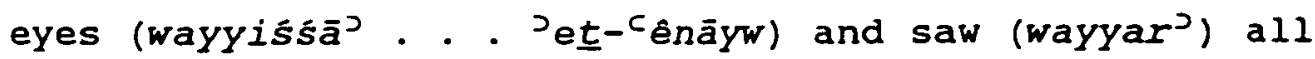
the valley of Jordan." 3

2. nāsă $q \delta \hat{I}=»$ băkāh: "And she . . lifted up her voice (wattiśśā’ Jet-qolāh) and wept (wattēblk)."4

3. nāsāo raglāyw =" hālake: "Then Jacob went on his journey (wayiśsāj . . raglāyw) and came (wayyēlek ) to the land of the sons of the east." s

'Gen 33:10. Cf. the negative command in Lev 19:15,

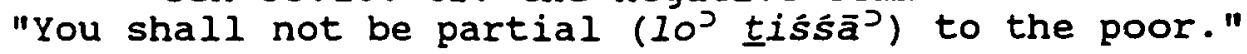

${ }^{2}$ Num $6: 25,26$.

${ }^{3}$ Gen $13: 10$.

'Gen 21:16. Cf. nātan qôl which apparently emphasizes more the loudness involved (see 1 Sam 12:17,18 and Jer $2: 15$ e.a.), whereas nās $\bar{a}^{\jmath}$ qôl just points out the use of the voice.

5only in Gen 29:1. A similar expression is possibly also found in 1 Sam 17:20 with raglāyw elided. Compare the expression ram (hiph) Jet-raqlo "move one's foot" in 
4. $n \bar{a} \bar{s} \bar{a}^{\supset}$ yād =" bāraḱ: "Then Aaron lifted up

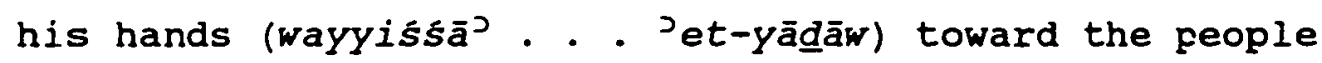
and blessed them (waýbāarkem)."I

$$
\text { 5. } n \bar{a} \bar{s} \bar{a}^{\supset} \text { yād }=\text { [šăb } \underline{b} a^{C} \text { (implied)]: "I will }
$$

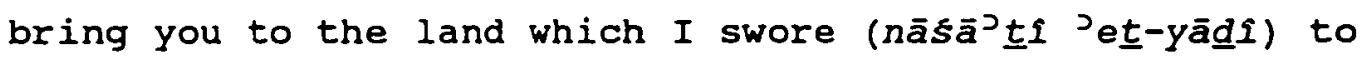
give to Abraham. . . .2

6. nāśa $\underline{k}^{e} l \hat{I} \Rightarrow$ șud: "Now then, please take your gear $\left(\hat{s}_{\bar{a}}{ }^{\supset}-n \bar{a}^{\supset} \underline{k} \bar{e} l \hat{e} \underline{k} \bar{a}\right)$. . and hunt a game for me

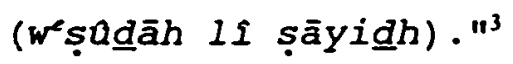

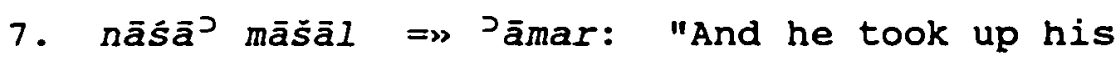
discourse (wayyiśs̄ā’ mišâlô) and said (wayYo’mar)."4

As this survey indicates the semantic range of the root nāsis is quite wide, permitting it to be used in a variety of contexts, and its flexibility in meaning is then honed by its context, within the framework, however,

Gen 41:44 indicating a general jncidental movement, whereas $n \bar{a} \bar{s}^{j}$ regel implies a purposeful move.

'Only here in Lev 9:22. Compare with the expression ram (hiph) $y a \bar{a} \underline{d}$ in Gen $41: 44$ where it implies a general incidental movement of the hand; Exod 17:11 indicating "holding up the hand"; Num 20:11 "lift the hand" for striking the rock, and $1 \mathrm{Kgs} 11: 26,27$ implying a rebellion.

${ }^{2}$ Exod 6:8. Actually the expression nāsa' yād has become a metonym for swearing an oath. The term for swearing an oath, $\check{s} a \underline{b} a^{c}$, is never used as a sequel, but the context implies that meaning.

${ }^{3}$ Only in Gen $27: 3$. 24.

only found in the story about Balaam in Num 23 and 
of its basic concept--that of a sustained upward movement for the purpose identified by the context.

\section{Literary context \\ Within the Pentateuch the verb $n \bar{a} \bar{s} \bar{a}^{\supset}$ is found in} both cultic and non-cultic passages--as table 19 indicates--in narratives, poetry, and legal texts, and it may be used either in a literal or metaphoric sense. within any of these classifications or combinations there is also a wide distribution of both morphological and syntactical forms.

Table 19 also indicates that the most common usage of $n \bar{a} \bar{s}^{2}{ }^{\prime}$ is in narrative passages, altogether 108 occurrences, or 63.9 percent; legal use makes up for 56

TABLE 19

DISTRIBUTION ACCORDING TO LITERARY FORMS

\begin{tabular}{|c|c|c|c|c|c|c|c|c|}
\hline \multirow[b]{2}{*}{ SUBJ } & \multirow[t]{2}{*}{ Usage } & \multicolumn{4}{|c|}{ Non - Cultic } & \multicolumn{3}{|c|}{ cultic } \\
\hline & & Narr & Poetry & Legal & Tot & Narr & Legal & Tot \\
\hline Man & $\begin{array}{l}\text { literal } \\
\text { metaphoric }\end{array}$ & $\begin{array}{l}15 \\
49\end{array}$ & 1 & $\begin{array}{l}1 \\
9\end{array}$ & $\begin{array}{l}16 \\
59\end{array}$ & $\begin{array}{r}13 \\
3\end{array}$ & $\begin{array}{l}13 \\
31\end{array}$ & $\begin{array}{l}26 \\
34\end{array}$ \\
\hline $\begin{array}{l}\text { God } \\
\text { Inani- }\end{array}$ & metaphoric & 13 & 2 & & 15 & 1 & 1 & 2 \\
\hline $\begin{array}{c}\text { mate } \\
\text { Animal }\end{array}$ & $\begin{array}{l}\text { metaphoric } \\
\text { literal }\end{array}$ & $\begin{array}{l}7 \\
3\end{array}$ & 1 & & $\begin{array}{l}8 \\
3\end{array}$ & 3 & & 3 \\
\hline & $\begin{array}{l}\text { metaphoric } \\
\text { metaphoric }\end{array}$ & 1 & 1 & & $\begin{array}{l}1 \\
1\end{array}$ & & 1 & 1 \\
\hline Tota & & 88 & 5 & 10 & 103 & 20 & 46 & 66 \\
\hline
\end{tabular}


cases, or 33.1 percent, and 5 times it is used in poetry, or 3 percent. It is found 103 times in non-cultic passages, or 60.9 percent, and 66 timas in cultic context, or 39.1 percent. Literal use accounts for 45 uses, or 27.2 percent, and it is used metaphorically 124 times, or 72.8 percent. However, there is no characteristic pattern discernible for the various meanings of the root nāsañ , Its shades of meaning appear to be entirely dependent on the context, without any direct relation to the literary form within which it is found.

\section{Summary}

on the basis of this survey it seems fairly safe to conclude that there is no morphological or syntactical evidence, or any other compelling indication, of the existence of more than one root nāśa $\bar{a}^{2}$ in the Hebrew old Testament, nor has it been found to be a part of any fixed technical expression. Closest to it are the expressions nāsā’ yād for "swearing an oath," and nāsa $\bar{a}^{J}$ roj for "taking a census," but even these appear to be rather a matter of metonymy rather than a termini technicae.

All the morphological, syntactical, and contextual evidence seems to point to a single, very flexible and neutral root which is fairly evenly distributed throughout all of the OT, without any significant difference noted between individual books or sections. What difference 
there is relates more to the subject matter of a given book than individual stylistics or development through time. No noticeable development was detected in the OT writings related to time, authorship, or sources. Based on the statistics presented, the use of the term is also quite uniform. The heaviest--and almost equal-concentration is found in the Pentateuch and the Later Prophets.

The verb is used almost exclusively in the Qal, or more than 90 percent. It occurs both in non-cultic and cultic contexts, and within each the verb may be found in different literary forms such as narratives, legal texts, or poetry. Historical, narrative books have the highest ratio of literal meanings with man as subject, whereas prophetic, instructional writings have a kigher ratio of metaphoric meanings and also a higher percentage of God as subject. Throughout, there is significant emphasis on concreteness; even the metaphoric usages appear to be based on earlier, literal actions. 
CHAPTER IV

SEMANTIC SCOPE OF $N \bar{S}^{\supset}$ IN THE PENTATEUCH

When the usage of nāśa in the Pentateuch is examined it becomes evident that it can be classified into five categories similar to those found in cognate languages. Most common are the aspects of (1) transport, and (2) support, but idiomatic expressions indicating (3) utilization of tools or parts of the human body, and (4) interpersonal relations are quite frequent, and finally there are usages in the context of (5) dealing with sin and wrongdoing. The first three are the subject of this chapter, whereas the last two are examined in the following chapters.

\section{Nāśáa and Movement}

In forty-two instances, or 24.8 percent of the total, the verb $n \bar{a} \bar{s} \bar{a}^{2}$ is involved in some kind of a movement from one place to another. The movement may be either indicated by a preposition or the directional $-\bar{a} h$ (eleven times), parallel expressions of movement (eleven cases), or by the general context (twenty cases). It must be noted, however, that in only seven cases is the 
morement explicitly indicated by certain morphs; $i^{1}$ all the other instances depend on the context for clarification, even if there is a preposition. In thirty-six instances persons are the subject, animals occur once, and other subjects such as wagons, wind, water, or kingdom are found six times.

\section{Formal Indications}

\section{Data}

Formal indications of movement are found in twenty-two cases and include morphs such as $\subset_{a l},{ }^{2} e l, m i n$, directional -āh, and parallel expressions of movement in the immediate context. Seventeen are in non-cultic narratives, and the remaining five in cultic texts.

1. Non-cultic setting

Gen $43: 34$

And he took (wayyiśsáa portions to them ( $\left.{ }^{a} l \bar{e} h e m\right)$ from his own table $\overline{\left(m \bar{e}^{-}\right.} \bar{e} \underline{t}$ pānāyw).

Gen $47: 30$

But when I lie down with my fathers, you shall carry me (un'śa' tani) out of Eqypt (mimmișrayim) and bury me in their burial place.

Gen 50:13 For his sons carried (wayyis ${ }^{2}$ a) him to the land (Jarṣāh) of Canaan.

Num 16:15 I have not taken $\left(10^{2} . .\right.$. $n \bar{a} \bar{a}^{\top} t\{)$ a single donkey from them (mêhem).2

$$
\text { 'Gen } 43: 34 ; 47: 30 ; 50: 13 ; \text { Exod 10:19; Lev 10:4, 5; }
$$
Num 16:15.

\footnotetext{
${ }^{2}$ Moses defends himself before the Lord against
} 
Exod 10:19

Gen $42: 26$

Gen $46: 5$

Exod $12: 34$

Gen $7: 17$

Exod 10:13

Num $23: 24$
So that the Lord shifted the wind to a very strong west wind which took up (wayyissa') the locusts and drove them into the Red sea (wayyitqā̄e èh yāmmāh sap) .

Gen 31:17, 18 Then Jacob arose and put (wayyiśs $\bar{a}^{2}$ ) his children and his wives upon camels (cal-hagg'mallim) - . to go to the land (Jarșāh) of Canaan.

So they loaded their donkeys (wayyiśs $\hat{u} \cdot \cdot{ }^{c} a l-h^{c}$ morêhem) with their grain, and departed from there.

Then Jacob arose from Beersheba; and the sons of Israel carried (wayyis $a$ ) their father Jacob and their little ones and their wives, in the wagons ( $b \vec{a}^{c a} q \bar{a} l o t \underline{t}$ ).

So the people took (wayyissā' their dough before it was leavened - bound up in clothes on (cal) their shoulders.

And the water increased and lifted up (wayyis'u) the ark, so that it rose above (wattārām $m \bar{e}^{c} a l$ ) the earth.

. . and when it was morning, the east wind brought (nāśà) the locusts. 1

Behold, a people rises (yāqam) like a lioness, and as a lion it lifts itself ( $y$ itnaśsás); It shall not

\footnotetext{
accusations by Korah and Dothan. He claims that he has never done them any wrong, not even taken a donkey from them. Later the prophet Samuel used a similar argument in his own defense (1 Sam 12:3). In that passage the verb lāqạ̣ is used instead of nāśà .

${ }^{1} \mathrm{Cf}$. vs. 14 where the expression "came up over all the land" is used concerning the result of this action.
} 
lie down (yiškabl) until it devours the prey.

Gen 45:19

Gen $45: 27$

Take wagons from the land of Egypt for your little ones and for your

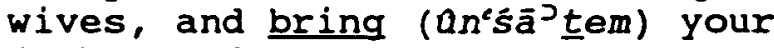
father and come.

Gen $46: 5 B$

When he saw the wagons that Joseph had sent to carry ( $1 \vec{a} \bar{s}^{3} \bar{e}^{\top} \underline{t}$ ) him, the spirit of their father Jacob revived. ${ }^{1}$

Num 13:23

. . in the wagons which Pharaoh had sent to carry (lās $\bar{e}^{\supset} \underline{t}$ ) him. ${ }^{2}$

Then they came to the valley of Eshcol and from there cut down a branch with a single cluster of grapes; and they carried it (wayyiśs $\left.\bar{a}^{\supset} u h a\right)$ on a pole between two men. ${ }^{3}$

Deut 14:24 If the distance is so great for you that you are not able to bring

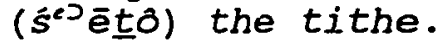

2. Cultic setting Lev $10: 4,5$

Come forward, carry $\left(\dot{s}^{c)} \hat{Q}\right)$ your relatives away from ( $m \vec{e}^{\top}$ et ) the front of the sanctuary to the outside ('el-mihas) of the camp. So they . . carried them (wayyiśsaum) still in their tunics to the outside (Jel-mihas ) of the camp.

'Cf. vs. 19 where the context indicates the idea of coming from one place to another.

${ }^{2} \mathrm{Cf}$. vs. $5 \alpha$ and $45: 19$ above where the idea of a movement is clearly indicated.

${ }^{3}$ The idea of transport is brought out by vss. 25 and 26 which reads: "when they returned from spying out the land, at the end of forty days, they proceeded to come to Moses and Aaron . . . and they brought back word to them - . and showed them the fruit of the land." 
Num 10:17

Num 10:21

Deut $12: 26$
And the sons of Gershon and the sons of Merari, who were carrying (nos $\left.{ }^{2} \hat{e}\right)$ the tabernacle, set out $\left(w^{c} n a \bar{s} c^{c} a\right)$.

Then the Kohathites set out

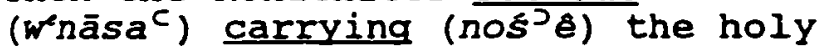
objects.

only your holy things which you may have and your votive offerings, you shall take ( $t i s^{s} \bar{a}^{2}$ ) and go to the

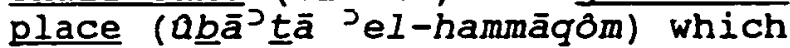
the Lord chooses.

\section{Comments}

In the six first passages a movement is clearly indicated by indicating both the goal and the point of departure (cal + min), tise point of departure or separation $(m i n),{ }^{2}$ or the point towards which the movement is directed ( ${ }^{2} a r s a \bar{a} h^{3}$ and yammāh ${ }^{4}$. The next four passages also include prepositions, but the movemnt is not clear except from the context. Three times we find the preposition ${ }^{c}$ al which can have both locational and terminative sense." once the movement is indicated by the

'Gen $43: 34$.

${ }^{2}$ Num 16:15. This is in fact the only time an animal is the object in the OT in contrast to both Ugaritic and Akkadian where an animal was occasionally the object in the context of sacrifices being brought (see chapter 2 ).

${ }^{3}$ Gen $50: 13$.

Exod 10:19.

SSee Bruce $K$. Waltke and M. O'Connor, An Introduction to Biblical Hebrew Syntax (Winona Lake, IN: Eisenbrauns, 1990), 216 . 
directional $-\bar{a} h$ in the next verse, ${ }^{\prime}$ once by the point of departure being indicated (mišs̆am), ${ }^{2}$ and once the movement can only be detected by the general context. ${ }^{3}$ In one passage t we find a combination of the preposition $b^{e}$ indicating the means of transport and a directional -āh indicating the goal of the movement. In three passages the movement is not indicated by any particular morph, but by parallel expressions in the immediate context: ram + $m \bar{e}^{-c} a l$ "rise above, "s cālāh cal "come up upon," $c^{6}$ and qum "rise up" in contrast to šăka $\underline{b}$ "lie down." Finally, in five instances the movement is implied by some expression in the context. Three of these are in the context of Jacob's moving to Egypt, having discovered that his son, Joseph, was still alive." All of them indicate how Jacob and his family were to use the wagons which had been "sent" from Egypt in order to "come" to Joseph. In one passage we are told about the spies taking a cluster of

${ }^{1}$ Gen $31: 17$ and 18 .

${ }^{2}$ Gen $42: 26$.

${ }^{3}$ Exod $12: 34$.

tGen 46:5.

${ }^{5}$ Gen $7: 17$.

${ }^{6}$ Exod 10:13.

${ }^{7}$ Num $23: 24$.

${ }^{8}$ Gen $45: 19,27 ; 46: 5 \beta$. 
grapes as a sample of the fertility of the land and bringing it back to the people.' Finally, the people are encouraged to bring their tithe to a given place, unless the distance is too great for it to be practicable. ${ }^{2}$

One passage in the cultic setting with two occurrences of the root has morphs which clearly indicate movement, ${ }^{3}$ both a point of departure or separation min (once) and the "goal" Jel-mihas (twice); two have contextual parallels: a verb of movement nāsāet and once the movement is indicated by a parallel verb and $a$ preposition of movement $\left(b o^{2}+2 e l\right) .^{5}$

\section{Contextual Indications}

Data

The remaining twenty passages have no direct indication of a movement, but the general context leaves no doubt that the emphasis is on movement rather than some stationary action. All the texts are in a cultic setting and most deal with the transport of various items of the

'Num 13:23. Cf. vss 25 and 26 where the idea of movement is brought out: "When they returned from spying out the land... They proceeded to come to Moses and Aaron . . . and showed them the fruit of the land."

${ }^{2}$ Deut $14: 24$.

${ }^{3}$ Lev $10: 4,5$.

tNum 10:17, 21 .

${ }^{5}$ Deut $12: 26$. 
tabernacle, when "the camp is to set out."l Four texts issue a warning against becoming contaminated by contact with "unclean" things."

a. Subject: the Levites

Num 1:50 But you shall appoint the Levites over the tabernacle of the testimony, and over all its furnish-ings and over all that belongs to it. They shall carry ( $y$ is $^{\supset} a$ ) the tabernacle and all its furnishings, and they shall take care of ( $\left.y^{\prime} \bar{s} \bar{a} r \underline{t} u h u \hat{u}\right)$ it.

Num 4:15 When the camp is to set out. . the sons of Kohath shali come and carry ( $\left.I \bar{a} \bar{s} \bar{e}^{2} \underline{t}\right)$ them. ${ }^{3}$

b. object: (i) the ark

Exod 25:14 And you shall put poles into the rings on the sides of the ark, to carry ( $\left.1 \bar{a} \dot{s}^{\prime} \vec{e}^{\top} \underline{t}\right)$ the ark with them.*

(ii) the table

Exod 25:27 The rings shall be close to the rim as holders for the poles to carry ( $1 \bar{a}^{\prime} \bar{s}^{-} \underline{t}$ ) the table.

'Num $1: 51 ; 4: 15,25$.

${ }^{2}$ Lev $11: 25,28,40 ; 15: 10$.

${ }^{3}$ See also parallel passages in Num 4:25; Deut 10:8; and $31: 9,25$.

the same expression is found in Exod 37:5.

${ }^{5}$ Also used in Exod $25: 28$ and $37: 14,15$. 
(iii) the altar

Exod 27:7 The poles shall be on the two sides of the altar when it is carried (bis'set 'otó).'

(iv) the altar of incense

Exod 30:4 They shall be holders for poles with which to carry $\left(1 \bar{a} s \bar{e}^{\supset} \underline{t}\right)$ it [altar of incense].2

(v) carcasses/corpses

Lev 11:25 Whoever picks up (wkkol-hannośe $\bar{e}^{2}$ ) any of their carcasses shall wash his clothes and be unclean until evening. ${ }^{3}$

(vi) contaminated items

Lev 15:10 Whoever then touches any of the things which were under him [a person with a discharge] shall be unclean until evening, and he who carries (whannôs $\bar{e}^{-}$) them shall wash his clothes. . .

\section{Comments}

Six times the transport of the tabernacle and its furnishings is said to be the responsibility of certain families of the Levitest, with one passage paralleling nāśa" with the verb šărat, meaning "to serve or minister in an official capacity as an official or a priest."

'See also Exod $38: 7$.

${ }^{2}$ Also in Exod $37: 27$.

${ }^{3}$ This expression is repeated in Lev $11: 28,40$.

${ }^{4}$ Num $1: 50 ; 4: 15,25$; Deut $10: 8 ; 31: 9,25$.

${ }^{5}$ Num 1:50. Holladay, 384; $\mathrm{BDB}, 1058$; and KBL, 1013, all give "serve," or "wait on" in a cultic context. 
NASB translates it as "they shall take care of it." Ten passages describe a technical aspect involved in making possible the transport of some items of the tabernacle: poles were to be made for the purpose of carrying its furnishings: the ark, the table, ${ }^{3}$ the altar of incense," and the altar.' A series of four passages are in the form of laws prohibiting any contact with ceremonially unclean objects, such as dead bodies, ${ }^{6}$ or items on which a person suffering from discharge has been sitting. ${ }^{7}$ The context implies that the main concern is not merely the act of a simple touch. It seems clear that the idea is rather one of moving the carcasses or the objects.

\footnotetext{
'The idea of caring was also found in Akkadian (see chapter 2 above), and it seems to form an integral part of the root-meaning both in Akkadian and Hebrew.

${ }^{2}$ Exod $25: 14 ; 37: 5$.

${ }^{3}$ Exod $25: 27,28 ; 37: 14,15$.

${ }^{4}$ Exod $30: 4 ; 37: 27$.

${ }^{5}$ Exod $27: 7 ; 38: 7$.

${ }^{6}$ Lev $11: 25,28,40$.

'Lev 15:10.

${ }^{8}$ So for instance Carl F. Keil and Franz Delitzsch, Biblical Commentary on the old Testament, vols. 1-3 (Grand Rapids: Wm. B. Eerdmans Publishing Company, 1949), 3:368 and A. B. Silbermann, ed., Pentateuch with Tarqum onkelos, Haphtaroth and Prayers for Sabbath and Rashi's Commentary, hereinafter Rashi (London: Shapiro, Vallentine \& Co., 1946), 2:46.
} 
It beccmes evident from this that the idea of movement may be included in the semantic range of nāsā?, but it is apparently not the primary meaning, for prepositions, morphs of movement or the context is usually needed to draw out that sense. This strengthens the earlier suggestion that the primary sense is in the area of sustained carrying. The use of different subjects and objects in different contexts, cultic or non-cultic, has apparently no significant impact on the usage or meaning of $n \overline{a s} a^{2}$. Its flexibility permits it to be used in various contexts and still retain its basic meaning. At the same time it adjusts the exact nature of the transport quite easily to the needs of the immediate context.

\section{Nāśa $\bar{a}^{\supset}$ as supporting}

\section{Data}

In fourteen instances the contextual emphasis of passages with $n \bar{a} \bar{s}^{j}{ }^{j}$ is on the aspect of ongoing support, ability to hold, or maintain. Again, it is mostly the context that indicates this. Seven times the verb takes a preposition of position or movement: twice the preposition of location ' $\bar{a} l,{ }^{1}$ four times $I^{e}$ indicating manner, ${ }^{2}$ and

${ }^{1}$ Num $7: 9 ; 16: 3$.

${ }^{2}$ Exod 20:7; Deut 5:11. Cf. Waltke, 206. Both passages are the same and repeat the same phrase 4 times. 


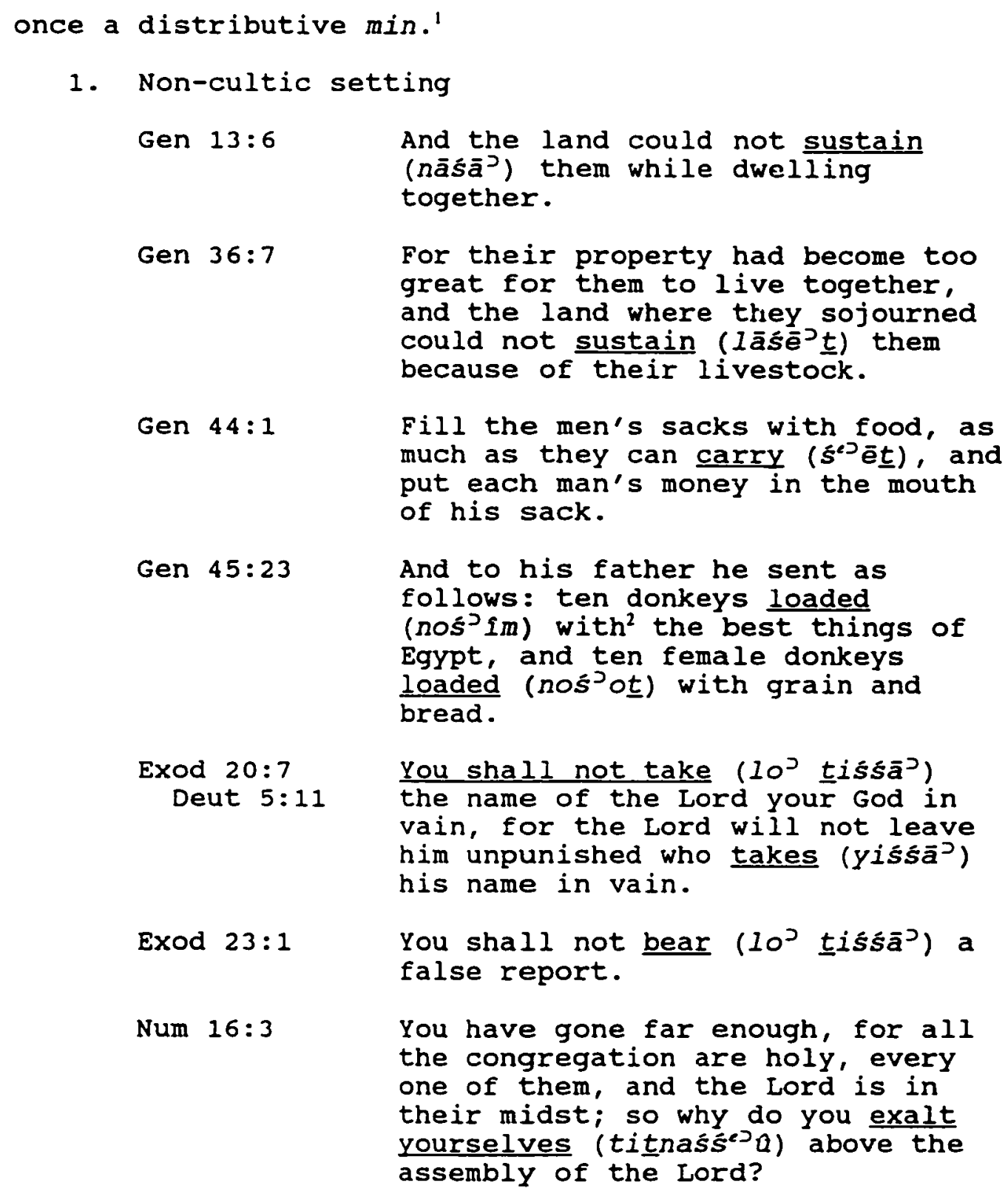

'Deut $33: 3$. It is, however, debated whether this is a prefixed preposition or an enclitic mem from the previous word (see discussion below). supplied.

'Not in Hebrew. Should be italicized since it is 
Num $24: 7$

Deut $33: 3$
And his king shall be higher than Agag, and his kingdom shall be exalted ( $w^{t} \underline{t} i n n a s ́ s \bar{e}^{2}$ ).

Yea, he loves the peoples; All his holy ones are in your hand, and they bowed down (tukka) at your feet, your word sustains them

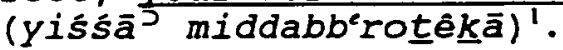

2. Cultic setting

Num $7: 9$

But he did not give any to the sons of Kohath, because theirs was the service of the holy objects, which they carried ( $y i s \bar{s} \bar{a}^{\supset} a$ ) on the shoulder.

\section{comments}

All the passage but the one in Num 7 are in noncultic contexts. In four of them the context implies an eventual movement, ${ }^{2}$ but the statements themselves emphasize the act of holding, supporting, carrying, sustaining, or maintaining. Eight of them have persons as subject, ${ }^{3}$ two have animals, ${ }^{+}$and four have inanimate subjects--the land, ${ }^{5}$ the kingdom, ${ }^{6}$ and God's word.

\footnotetext{
'Translation mine.

${ }^{2}$ Gen $44: 1 ; 45: 23(2 x)$, and Num 7:9.

${ }^{3}$ Gen $44: 1$; Exod $20: 7(2 x) ; 23: 1 ;$ Num $7: 9 ; 16: 3 ;$ and Deut $5: 11(2 \mathrm{x})$.

tGen 45:23 (2x).

${ }^{5}$ Gen $13: 6 ; 36: 7$.

ONum $24: 7$.

${ }^{7}$ Deut $33: 3$.
} 
The first two passages, Gen $13: 6$ and $36: 7$, are similar in content. Both deal with the problem arising when two rich men occupy the same area with their livestock. The land could no longer produce enough grass and grains to "sustain them," (i.e., provide them with their sustenance).'

In the following passages, Gen $44: 1$ and $45: 23$, the emphasis is on the load that is to be carried without any real concern for the transport per se. Both man and the animals are supporting the load that is placed upon them. The passages in Exod 20:7 and Deut 5:11 are identical. They are a part of a legal code, or more specifically, the Ten Commandments. As to their exact meaning, varied opinions exist, especially when it comes to the meaning of "in vain" in this context." It is a translation of the Hebrew term šäw which is commonly translated as "worthless," "what is empty," 3 "nothingness," "insubstantial thing" or a "Iie." 4 Keil and Delitzsch do not agree. They say:

\footnotetext{
"This idea of "providing for" or "sustaining" was also found in Akkadian (see chapter 2).

2See Timo Veijola, "Das dritte Gebot (Namenverbot) im Lichte einer ägyptischen Parallele," AW 103 (1991):117.

${ }^{3}$ See Holladay, 361-2.

JJohn I. Durham, Exodus, Word Biblical Commentary (Waco, TX: Word Books Publishers, 1987), 287-8.
} 
šā $w^{\supset}$ does not signify a Iie (šeqer), but according to its etymon $\bar{s} \bar{a} \supset \bar{a} h$, to be waste, it denotes that which is waste and in disorder, hence that which is empty, vain, and nugatory, for which there is no occasion.' Klopfenstein is basically in agreement with this conclusion, except he sees the term going deeper, to include what he calls "die Ambivalenz 'UnheilvollesKraftloses." "' $\zeta \bar{a} w^{\supset}$ is thus a term indicating something lacking in substance, whether that substance be power, truth, reliability, or fullness.

on this basis different interpretations of the third commandment have surfaced through the centuries. Ehrlich has pointed out that "wahrscheinlich steht tiśsā?

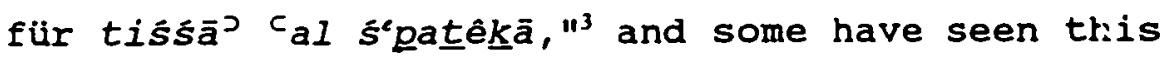
commandment to be the basis for the rabioinic practice of not pronouncing the Tetragrammaton. Ehrlich claims, however, that this notion cannot be substantiated, but this was rather seen as a

Verbot, den Namen JHVHs leichtsinnig im Munde zu führen, ihn unnötiger Weise auszusprechen und namentich bei ihm, da wo es sich um gleichgiltige Dinge handelt, zu schwören."

Mowinckel, on the other hand, sees the commandment warning against the misuse of the name of Yahweh "als

'Keil and Delitzsch, 1:118.

${ }^{2}$ Martin A. Klopfenstein, Die Lüge nach dem Alten Testament (Zürich: Gotthelf Verlag, 1964), 320 .

${ }^{3}$ Ehrlich, $1: 341$.

tIbid. 
Beschwörungsformel in egoistischer und anderen Leuten schändlicher Absicht."' Noth agrees, but adds "Zauberhandlungen,"2 whereas von Rad sees it mainly "directed against false swearing." 3

W. E. Staples has argued for a different approach. Having shown that $\check{s} \bar{w}^{2}$ is one of the epithets of idols in the $\mathrm{OT}^{\mathrm{t}}$ he suggests the possibility of reading the commandment as: "Thou must not lift up the name of Yahweh, thy God, to an idol," implying the act of attaching his name to them.' That argument, however, is not very convincing, since the aspect of loyalty to the "one, true God" has already been covered in the first commandment. More convincing is Veijola ${ }^{6}$ as he draws on Biblical and

'Sigmund Mowinckel, Psalmenstudien (Amsterdam: P. Schippers, 1966), 1:52, quoted in Klopfenstein, 316.

${ }^{2}$ Martin Noth, Das zweite Buch Mose. Exodus, Das Alte Testament Deutsch. Neues Göttinger Bibelwerk, (Göttingen: Vandenhoeck \& Ruprecht, 1965), 131. Quoted in Klopfenstein, 316.

${ }^{3}$ Gerhard von Rad, old Testament Theology, 2 vols., trans. D. M. G. Stalker (New York: Harper \& Row, Publishers, 1962), 1:183-4. This is also supported by Keil and Delitzsch, 1:118.

${ }^{4}$ Quoting Jer $18: 15$.

SW. E. Staples, "The Third Commandment," JBL 58 (1939): 329 .

Veijola, 5-12. He cites an Egyptian votive inscription from the nineteenth dynasty besides an almost identical biblical parallel from Ps $24: 4$ in which the

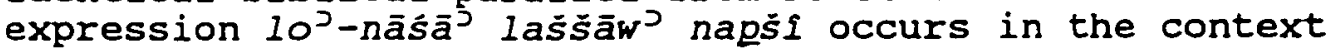
of swearing a false oath. He also points out that the use of nāsás probably is a metonymy for lifting of the hands 
extra-biblical parallels, where šâw is used parallel with šăger in the context of making oaths.

It seems, however, important to look at šāw ${ }^{2}$ in

the context of šem which has a broader sense here than merely being mentioned in oaths. A name in Hebrew usually stands for the essence or character of its bearer, or even life itself.' The passage should therefore be seen as a warning against presenting God's character as empty, lacking substance, and thus lying about it, giving a wrong impression of who God really is. But Durham may be right when he observes that

this commandment is couched in language deliberately chosen to permit a wide range of application, covering every dimension of the misuse of Yahweh's name. ${ }^{2}$

Whichever interpretation is adopted it appears that the meaning of nāsà in this context has to do with "holding up" (i.e. presenting) a false impression of God's character. ${ }^{3}$

in oaths (Exod 6:8; Ezek 20:6, 15, 23; and Ps 106:26). In Exod 23:1-7 $\check{s} \bar{w}^{\supset}$ is used in parallel with šeqer "a lie," and even within the ten commandments themselves this parallel is found, as we compare the two "versions" in Exod 20 and Deut 5 where 'éd sāger of Exod 20:16 is replaced by ${ }^{C} \bar{e} \underline{d} \bar{s} w^{2}$ in Deut $5: 20$.

'See the theophany in Exod $33: 18-23$ and $34: 5-7$. Also A. S. van der Woude, "DU, šēm Name," THAT 2:939; and Stamm, "Dreißig Jahre Dekalogforschung," Theologische Rundschau, $27 / 4$ (1961):289.

${ }^{2}$ Durham, 288 .

3Stamm, "Dreißig Jahre . . ." 290, points out an interesting parallel from the rules of the harems of the 
The passage about the false report in Exod 23:1 has also been the subject of various interpretations, depending on whether to understand $n \bar{a} \bar{s} \bar{a}$ ' as "to carry" or "to accept, take". Most modern English translations seem to take the former view, whereas a few scholars favor the latter.' Even the ancient versions are divided on this issue. LXX has $\pi \alpha \rho \alpha \delta \epsilon \xi \eta$ "accept, acknowledge," and the Targum onkelos and Neophyti have tqbyl and tqblwn "accept, receive" respectively, whereas Peshitta has ť̆r "let go, start." Even though an initiation of a rumor may be involved, it seems more likely, in light of the present research and the immediate context, that the emphasis is more on the idea of keeping the rumor alive than starting it, considering the fact that nāsa $\bar{a}^{2}$ tends to place the emphasis more on the ongoing action than only its initiation. The passage might then be translated as: "Do not sustain (or: keep alive) something that is only an unsubstantiated rumor."

The passage in Num 7:9 is in the context of instructions concerning the transport of the furnishings of the tabernacle. The leaders provided the Levites with

Assyrian kings (in Weidner, 279, rule 10, line 57-58): $i-$ na sa-al-ti-ši-na šu-[um il]i a-na ma-šik-te ta-zak-ru-uni ("Entweder Gatinnen des königs oder niedrige Frauen, die.. . sich gegenseitig schlagen), in ihrem streit den Na[men der Gotth]eit mißbräuchlich anrufen."

'Ehrlich, 1:356. Marginal reading in $\mathrm{kJV}$. 
oxen and carts for that purpose, but the Kohathites received no oxen or carts, for they were responsible for the furnishings of the holy--the table, altar of incense and the lampstand--all of which were to be carried on the shoulders by means of poles.' Even though the idea of transport is definitely present in the text, the emphasis is more on the contrast between different groups of Levites. Most of them received oxen and carts on which to load their items, but the Kohathites were to load and carry their particular burdens on their own shoulders. The two passages from Num 16 and 24 have the verb nāsāj in the hithpael which most frequently has a reflexive or reciprocal meaning, but may occasionally have passive meanings. ${ }^{2}$ The former is in a narrative, whereas the latter is in prophetic poetry. In the last passage

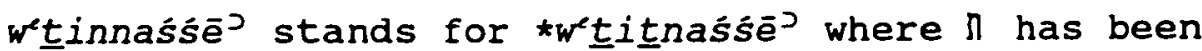
assimilated to a J. Apart from this, the structure is quite normal.

In Num 16 Dathan and Abiram accuse Moses and Aaron of desiring to be in charge of the people, "Why will you place yourselves ( $t$ itnaśs $\hat{s}^{\mathrm{J}}$ a) over the congregation of the Lord?" Even though the prepositional phrase cal-q'hal may indicate both the direction and the place of the activity,

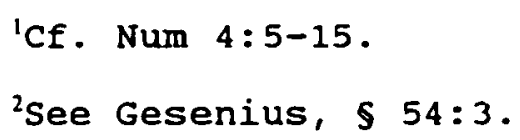


the context seems rather to imply that the accusation has to do with the unwillingness of Moses and Aaron to share their leadership role with others. It appears to be emphasizing the maintenance of a status quo, holding on to a leadership role rather than the aspiration of a new role.

The passage in Num 24 involves a comparison as Balaam is predicting the future glory of Israel. He claims Israel's king will be higher than the king of the enemy, and its kingdom will be/remain exalted, indicating a status being maintained rather than one to be attained. In the last passage, Deut 33:3, there are several textual problems: hab cammim for "people" is indefinite plural, even though the context suggests singular; there is a mixture of the pronouns "his" and "thy," tukku occurs only twice in the OT, the subject of yiśsa ${ }^{2}$ is uncertain as is the function of the prefixed $D$ in the last word. Similar problems are also found in the verses immediately preceding and following. Several solutions have been suggested, all of which involve more or less emendations, because it seems evident that the text is partially corrupt in these verses.

Since, however, a correct understanding of the details in this passage is not crucial to the current study, we only look at the possible meaning of tukko 
and the last phrase and then suggest a translation in which the verb nāsāj retains its basic meaning without violating the context.

According to the Massoretic annotations the form tukka occurs only here and in Isa 1:5 where it is seen to be hophal imperfect of nākāh "to strike, hit, beat."l That meaning, however, does not seem to fit the context here.

Some $^{2}$ suggest that "they" refers to the heavenly host in vs. 2 who is ready to perform God's biddings, whereas others see it as referring to the people of God. ${ }^{3}$ Targum Onkelos, Targum Neophyti, and the Peshitta all suggest that it refers to the people who are being led by God. Cross and Freedman have argued, however, that tukka might be read together with the previous words, forming *himtakku a hištaqal form of the root $m k k^{4}$ with an infixed $\Pi$, meaning "to bend, be low or humiliated."s

${ }^{1}$ Holladay, 237-8.

${ }^{2}$ So Frank M. Cross and David Noel Freedman, "The Blessing of Moses," JBL 67 (1948):193, and I. Seeligmann, "A Psalm from Pre-Regal Times," VT 14 (1964):77-78.

${ }^{3}$ The Targums, Rashi, 2:170; Andrew D. H. Mayes, Deuteronomy, New Century Bible (London: Olıphants, 1979), 400. Most modern translations apparently follow their lead.

AAlso found in Ps 106:43; Eccl 10:18; and Job 24:24.

5cross and Freedman, 200-1. They are followed by Mayes, 400, and Duane L. Christiansen, "Two Stanzas of a Hymn in Deuteronomy 33," Biblica 65 (1984):387. 
The last phrase causes the main problem. What is the subject of yissā? Is it the people or possibly the word? The Targums saw the context referring to the guidance the people received from God on their journey and translated it, "they moved according to your words." Many modern translations follow the LXX and the Peshitta in taking yiśsā" as "receiving," either with the people (collective) or the distributive "Everyone . . ." as subject. ${ }^{3}$ They see this passage referring to the people receiving the Decalogue as the following verse indicates.

cross and Freedman argue for a minor emendation in order to make the translation "smoother." They do not see any need, however, to change the consonantal text. It is only necessary to join the prefixed $D$ in middabbroteka to

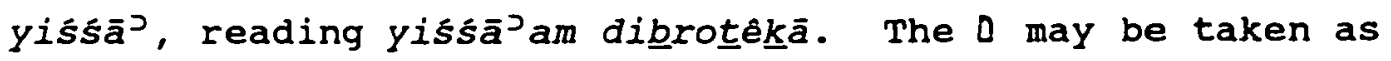
enclitic, a common feature in old Hebrew poetry. ${ }^{4}$ This provides the meaning, "they carry out your words (or: decisions)." Mayes follows their suggestion but sees the final $\Delta$ as a masculine, plural pronominal suffix, thus

'See Targum Neophyti.

${ }^{2}$ Rashi, 2:170; NASB.

${ }^{3}$ Keil and Delitzsch, 3:498.

'See Horace D. Hummel, "Enclitic Mem in Early Northwest Semitic, Especially Hebrew," JBL 76 (1957):85107, especially pp. 92-95 and 103-5.

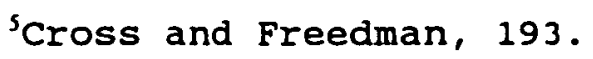


translating, "your words lift them up"l or "your words uphold (or: sustain) them," which would agree with the context and also the overall meaning of nāsā’ discussed above. Selecting this option makes "words" the subject rather than the object of the verb. ${ }^{2}$

Even though the meaning "support" is not as common as that of "transport" in the Pentateuch, that idea is usually basic to the one of "transport." Transport presupposes support. The distinction between these shades of meaning is not based on morphology or syntax alone, but

'Mayes, 400 .

${ }^{2}$ The text has been enigmatic for centuries; even the ancient versions struggle with it. For the relevant portion of the passage, LXX has: "and they received from his word [a] law which Moses commanded us." Tgo has "they lifted up the stakes (=moved) according to your word." TgN supports that meaning by "they set out and encamped according to his word." Peshitta has "they followed closely after his feet and received of his word." All of them seem to agree that the sense is that the people was guided by God's word. A suggestive, literal translation of vss. 2 through 4 would run as follows: "The Lord has come from Sinai, He has dawned on them [the people] from Seir, He shone forth from the mount of paran [these locations referring to God's glory being visible throughout the wilderness wandering], and He came from [or: in association with] a myriad of holy ones; from His right hand (came) fiery law (?) [possibly referring to the way in which the law was given. The meaning of Jesdat is unknown. The marginal annotation in the MT suggests a Qêre of 'eś dāt "a fire (of) law"] for them. Yea, the lover of peoples [or: the tribes], all his holy ones are in your hand [both "his" ar.: "your" refer to God], and they bowed down [or: were humbled] at your feet [at Sinai], your words sustain them [or: (as they) receive of your words]. Moses commanded us the Law, the possession of the assembly of Judah." Both of the options in the last phrase are well acceptable, and their message is basically the same. Only the emphasis is different. 
is drawn out by the context. It is found both in cuitic and non-cultic settings with persons, animals, or inanimate subjects, but that fact does not appear to have any significant impact on the meaning.

\section{Nāśä as Utilizing}

In fifty-one texts the emphasis is neither on the idea of transport nor that of support, but rather that of the utilization or employment of a given object. Most frequently this meaning is found in the context of body parts or functions (thirty-nine times), but it also involves weapons once, words, eight times; and man, three times.

\section{Weapons as objects}

Data

In one passage in the Pentateuch we find nāsa $\bar{a}^{2}$ being used with weapons.

$\begin{array}{ll}\text { Gen 27:3 } & \text { Now then, please take }\left(s \bar{a}^{2}-n \bar{a}^{2}\right) \\ & \text { your gear, your quiver and your } \\ & \text { bow, and go out to the field and } \\ & \text { hunt a game for me. }\end{array}$

\section{Comments}

The indication of nās $\bar{a}^{\supset}$ in this passage is not that of transporting the weapons to the field, nor the thought of them being a load that needs to be carried, but rather their utilization for the purpose indicated by the sequel of hunting a game. 
Body Parts and Functions

Forty-five times in the Pentateuch there are expressions combining nāsā’ and body parts or functions.' Practically all of them are metaphoric (i.e., they do not necessarily involve a literal, visual, and/or measureable movement), or that movement is not the issue in question. They are really idioms which originally may have described a literal action, but later became a fixed expression for the effect rather than the act itself. In Hebrew the following body parts or functions are involved (listed in the order of descending frequency): the eyes, head, voice, heart, hand(s), feet, and soul. All of these appear as the object of nāsià except the heart which functions as subject in the Pentateuchal passages.

\section{Eyes as Object}

Data. Nāsāj is used with the eyes eighteen times in the Pentateuch, compared with thirty-three times in the rest of the OT. Generally speaking, both translators and commentators take this expression to indicate a literal upward movement of the eyes. A closer look at its actual usage, however, indicates that this is not necessarily the case.

\footnotetext{
${ }^{1} \mathrm{~N}$ ine of these--Gen $19: 21 ; 32: 21 ; 40: 13,19,20 ;$ Lev 19:15; Num 14:30; Deut 28:50; and 32:40--are associated with interpersonal relations and therefore discussed in chapter 5 .
} 
Gen 13:10

Gen $13: 14$

Gen $18: 2$

Exod $14: 10$

Deut $4: 19$

Gen $39: 7$
And Lot lifted up his eyes and saw

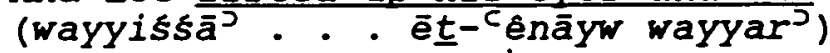
the valley of Jordan.'

Now, lift up your eyes and look

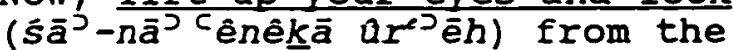
place where you are northward and southward and eastward and westward.2

And when he [Abraham] lifted up his eyes and looked, behold (wayyiśsā? 'ênāyw wayyar' whinneh), three men were standing opposite him. ${ }^{3}$

And as Pharaoh drew near, the sons of Israel looked, and behold

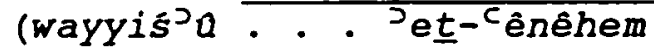
whinneh) the Egyptians were marching after them.

And beware, lest you lift up your

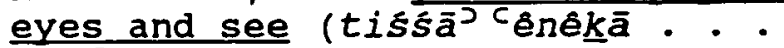
$\left.w^{e} r \bar{a}^{2} i t \bar{a}\right)$ the . . . host of heaven and.. Worship them.

His master's wife looked with desire (wattiśśà) . . . 'et-

cênêhā) at Joseph, and she said, "Lie with me".

Comments. C. S. Reif has pointed out that the expression nāŝẩ cayin has received very little serious

'A similar expression is also found in Gen 22:4; $24: 64 ;$ Num $24: 2 ;$ Gen $33: 5 ;$ and $43: 29$. In the last 2 the subject is not mentioned in the phrase itself but in the previous verse.

Deut $3: 27$.

${ }^{2} \mathrm{~A}$ similar expression is also found in Gen $31: 12$ and

${ }^{3}$ Similar expressions with a double sequel are also found in Gen $22: 13 ; 24: 63 ; 31: 10 ; 33: 1 ;$ and $37: 25$.

tThe expression "with desire" is not in the Hebrew. Being a supplied interpretation, based on what is implied by the context, it should be in italics. 
attention through the centuries.' Evidently no one seems to have regarded this expression "sufficiently controversial or problematic to warrant lengthy comment." 2 Even modern translations have improved little on the traditional translation of "to lift the eyes." ${ }^{3}$ Most "modernizing" has consisted in replacing "lift the eyes" with "raise the eyes."

However, the most recent dictionaries reveal the awareness "that 'lifting the eyes' in Hebrew is not necessarily to be equated with the English idiom "look up."I In fact, the employment of this expression "in no way presupposes that the object of such vision is on a higher level than the observer." ${ }^{6}$ Frequently the opposite is the case: Moses on Mount Pisgah overlooking the Promised Land, likewise Abraham and Lot in their time, Rebekkah noticing Isaac from upon the camel, ${ }^{7}$ and Joseph

'C. S. Reif, "A Root to Look Up? A Study of the Hebrew nāśă cayin," VTS 36 (1985):230-44, especially pp. $232-36$.

${ }^{2}$ Ibid., 234

'Ibid. See especially Reif's discussion of the trend in various contemporary versions, pp. 231-2.

${ }^{4}$ Ibid., 235 .

${ }^{5}$ Ibid. , 237.

${ }^{6}$ Ibid., 240.

${ }^{7}$ Gen $24: 64$. 
looking at his brothers.' This is also confirmed as we look at texts outside the Pentateuch. They show that the expression nāśa cayin is generally followed by either a sequel or a directional morph which would be unnecessary if the idea of lifting was inherent in the verb itself. There are prepositions such as ${ }^{2} e l,{ }^{2} C_{a l^{3}}$ or $I^{e} i^{4}$ expressions which specify an upward movement like mārôm; or others which indicate a round about movement, as does sāblib.o The last two expressions in particular give the impression that the verb itself is directionally neutral and needs to be further defined by other morphs or the context to indicate even an upward move. Ehrlich appears to be one of the first commentators to draw attention to the fact that when nāsāa is used with parts of the body it does not mean "to lift" but rather it is clearly being used in the idiomatic sense of

'Deut 3:27; Gen 13:10, 14; and Gen 43:29 respectively.

${ }^{2}$ Ezek 18:6, 12，15; 33:25; Ps $121: 1 ; 123: 1$; Ezek $23: 27$.

${ }^{3}$ Jer $3: 2$.

Is $51: 6$.

$5_{2} \mathrm{Kgs} 19: 20$ and its parallel passage in Isa $37: 23$ and Isa $40: 26$.

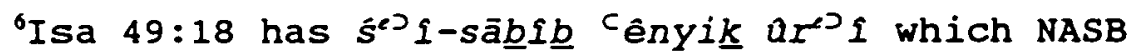
translates as "Lift your eyes and look arcund." A more accurate translation would be "Look around and see." 
activating them.' He has been followed by E. A. Speiser who claims that the expression is not used "to signify degree or volume, but with the shading of 'to pick up,' to focus attention on the activity involved." 2 C. S. Reif then concludes correctly that "the idiom nāsāa cayin carries the basic sense of 'activating the eye' i.e., deciding to employ one's visual faculty."3

As to the double sequels, it appears that whinneh adds a moment of surprise to the act, pointing out something that came unexpectantly to the attention of the viewer. ${ }^{t}$ This can be seen in all the occurrences of hinneh: Abraham noticing the presence of three strangers near his tent, ${ }^{5}$ or seeing the ram in the thicket at the time of the sacrifice of Isaac, Isaac catching sight of the approaching camels bringing his future bride,' Jacob noticing the speckled traits of the rams mating, and

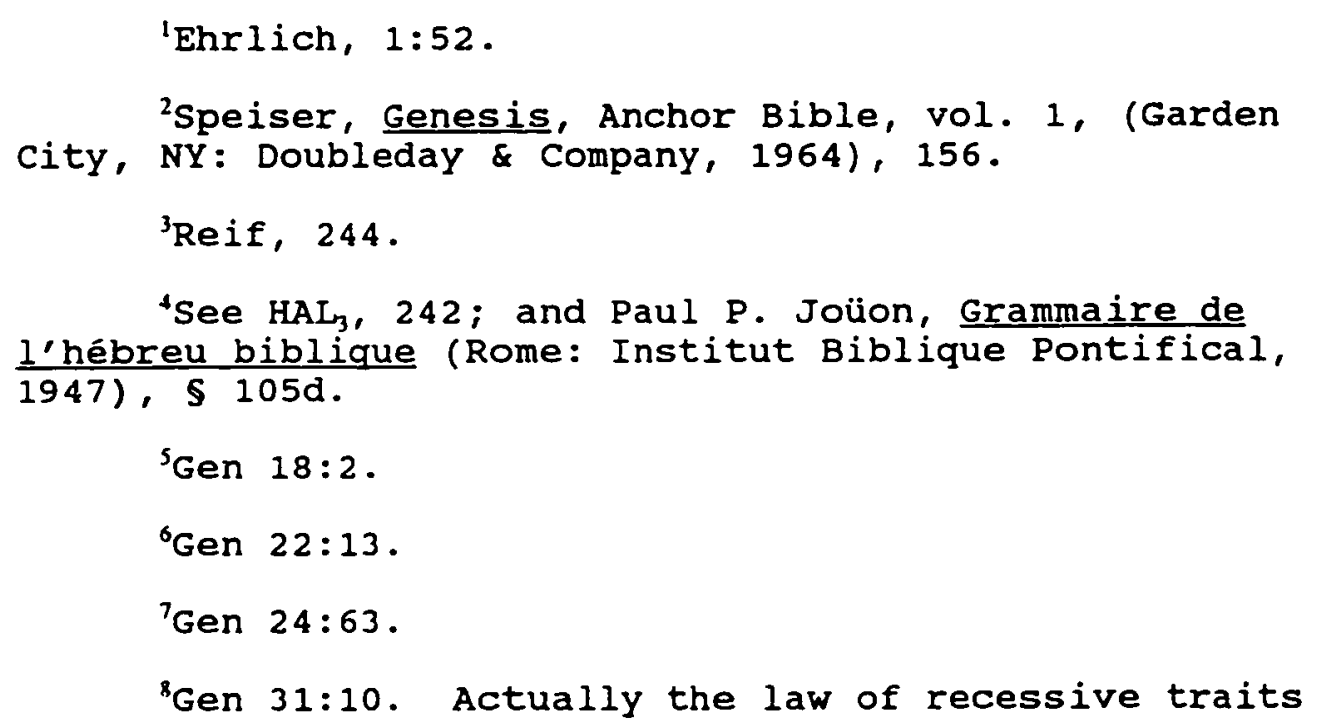

${ }^{5}$ Gen $18: 2$.

${ }^{6} \mathrm{Gen} 22: 13$.

${ }^{7}$ Gen $24: 63$.

${ }^{8}$ Gen 31:10. Actually the law of recessive traits 
suddenly seeing Esau approaching.' It is also used of Joseph's brothers as they noticed the arrival of the Ishmaelite traders ${ }^{2}$ and the Israelites as they were surprised by the sudden arrival of the Egyptian army by the Red Sea. ${ }^{3}$

The passage in Gen 39:7 is different from the others as it is the only one in the Pentateuch in which nāsāa cayin has no sequel. Comparing it to similar constructions outside the Pentateuch, we notice that without a sequel the expression has more the sense of a mental attitude than that of actually seeing." Most frequently it is used about diverting the attention towards a particular object, usually idols or enemy nations, with a desire or an expectation.

The use of nāsáa in these expressions thus implies a purposeful, conscious act of looking, in contrast to the

was being revealed to Jacob in the dream. On the surface all the animals were white, but some had recessive genes for speckledness. It was revealed to him that these were the ones that mated.

'Gen 33:1.

${ }^{2}$ Gen $37: 25$.

${ }^{3}$ Exod 14:10.

${ }^{4} \mathrm{Cf}$. passages such as $2 \mathrm{Kgs} 19: 22$ (=Isa $37: 23$ ) where it implies haughtiness; Ezek 18:6,12,15, and $33: 25$ where the eyes are turned toward idols; and Ezek 23:27 where the object is lewdness and harlotry. 
incidental happening when the simple $r \bar{a}^{\supset} \bar{a} h$ is employed.' The effect of $n \bar{a} \bar{s}^{2}$ in this context is somewhat ingressive in nature, ${ }^{2}$ and is to a certain extent similar to the English expression "turn the eyes [or: the attention] towards something."

Head as Object

Data

In this category we find twelve passages in the Pentateuch. Three are in the context of interpersonal relations, ${ }^{3}$ with the remaining nine in the context of taking a census or mustering. Eight are in the book of Numbers alone.

Exod $30: 12$

$$
\begin{aligned}
& \text { When you take a census (tiśsás Jet- } \\
& \text { ro's) of the sons of Israel to } \\
& \text { number them (Iipqudêhem) then each } \\
& \text { one of them shall give a ransom for } \\
& \text { himself to the Lord." }
\end{aligned}
$$

\footnotetext{
$6: 39$.

'See Franz J. Stendebach, "I' , Cajin", TWAT (1989),

${ }^{2} \mathrm{Cf}$. the use of ingressive aorist in Greek. E.g.,
} Friedrich Blass and Albert Debrunner, A Greek Grammar of the New Testament, trans. by Robert Funk (Chicago: The University of Chicago Press, 1961), 171, \$331; and A. T. Robertson, A Grammar of the Greek New Testament in the Light of Historical Research (Nashville: Broadman Press, 1934), 834 .

${ }^{3}$ Gen $40: 13,19,20$. Besides, there are five texts with face as object--Gen $32: 21$; Lev 19:15; Num 6:25; Deut $10: 17$; and 28:50. All are discussed in chapter 5 since their emphasis is on interpersonal relations. and $26: 2$.

4For a similar statement, see also Num $1: 2 ; 4: 2,22$; 
Num $1: 49$

Num $31: 26$

Num 31:49

Num $3: 40$ only the tribe of Levi you shall not number ( $10^{2}$ tipgod), nor shall you take their census (w'et-ro'sām

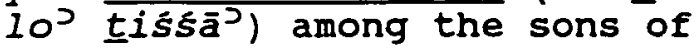
Israel.

Take a count $\left(\bar{s} \bar{a}^{\supset}{ }^{2} \bar{e} t\right.$ rop $\left.O^{\supset}\right)$ of the booty that was captured, both of man and of animal.

Your servants have taken a census $\left(n \bar{a} \bar{s}^{C J} \mathrm{u}\right.$ et $\left.t-r o^{2} \dot{s}\right)$ of the men of war who are in our charge, and no man of us is missing.

Number every first-born male ( $p$ qog kol-bek $\underline{\text { or }} z \underline{\bar{k}} \bar{a} r)$ of the sons of Israel from a month old upward, and make a list of their names ( $w^{e} \xi \bar{a}^{\text {? }}$

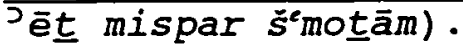

Comments

All these passages, except Num 31:49, are in the form of non-cultic instructions, and all of them convey the idea of some kind of counting which is unique to the Pentateuch. In other Biblical passages this expression is never used in that sense, but rather conveys the idea of rebellion,' self-assurance, ${ }^{2}$ or restoration of an individual. ${ }^{3}$ The fact that ro's is always used in the singular in these Pentateuchal passages, even though the context is clearly plural, is a strong indication that it is used idiomatically rather than literally. The

\footnotetext{
Judg $8: 28$; and Zech $2: 4$.

'Job $10: 15$.

${ }^{3}$ See chapter 5 .
} 
expression is apparently similar to the English "take a head-count."

The last passage is in a similar context to the other passages, but instead of the expression nāsā ro ro

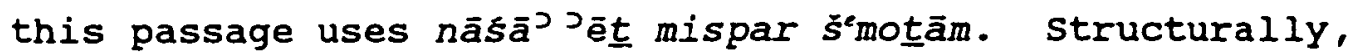
it does not differ from the other census passages. It is apparently only a matter of approach or emphasis. The context seems to call for an action for the purpose of establishing or verifying the list of names of those who were counted for a particular purpose. Rashi has argued that

they brought their records of pedigree and witnesses to confirm the prevalent presumption regarding their parentage, so that each might establish his pedigree with regard to that particular tribe.'

All of these passages are in some way connected with the act of taking a census, mostly for the purpose of assigning a position in the community. In five of these

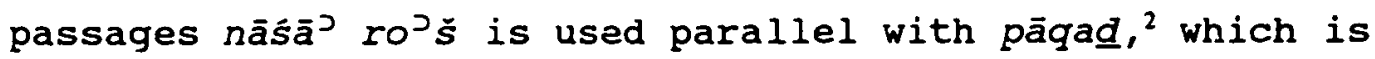
usually translated as "call up (for duty)," "muster" or "appoint" in these contexts." Gunnel André has discussed quite extensively the relationship between pāqad and nāsāa ro's $^{2}$ and comes to the conclusion that there is

\footnotetext{
'Rashi, on Num $3: 18$.

${ }^{2}$ Exod $30: 12$; cf. vss. 13 and $14 ;$ Num $1: 2,49 ;$ cf. vss. 3 and $49 B ; 4: 2,22$; Cf. vss. 34 and 38 .

${ }^{3}$ See Holladay, 296, and KBL, 773 .
} 
1. A close relationship between nāsis ${ }^{\supset} \bar{e} t \underline{t}$ roj and pāqad, but they are not interchangeable. They can be coordinated in an order/prohibition and in that position nāsā' Jēt ro $O^{\supset} \check{s}$ appears first. . . .

2. They have the same subjects and objects. . .

3. Both verbs imply an action to be done with a large crowd of people according to certain principles of assortment.

4. The results of both verbs is [sic] a large number of pequalim.'

There is, however, some question about his first point. In Num $1: 48$ and 3:40 pāqad appears in the first

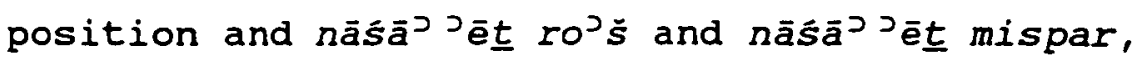
respectively, in the second position. André states concerning the first passage that "in the only example of prohibition the order is reversed."2 He gives no explanation of the second. It seems, therefore, more in line with the evidence to accept these expressions as practically synonymous.

Exactly what was involved in this process is disputed among scholars. Most translations and commentators take the approach that it refers simply to the taking of a census. André comes to the conclusion, based on his study of pāqad, that it implied "determin[ing] the destiny of the congregation according to its fitness to perform a

'André, 117.

${ }^{2}$ Ibid. 
certain task"' which frequently was related to military service. This is definitely the case in Num $1: 2,49,50$ where Moses is commanded to "take head-count" of all who were of serviceable age. It included only males over twenty years of age, and the Levites were not included. Later, however, 2 the "head-count" involved the Levites as they were being assigned their duties related to the sanctuary.

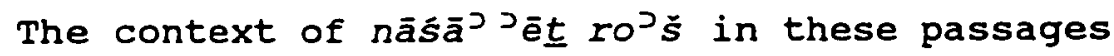
seems to demand a process of selective "head-count" for the purpose of appointing to or assigning some specific duties, either military or cultic. The only exception-Num $31: 26,49--$ is more general in its scope, as it involves captives and cattle alike, without the assignment of any duties. This may indicate that even though the expression usually and basically implied assignment to duties it was not exclusively a terminus technicus for census-taking. Rather, it was a general term which at times was used as metonymy for any kind of counting or checking, in line with the evidence also found in Akkadian. ${ }^{3}$

'Ibid., 240-1.

${ }^{2}$ See Num $4: 22,29$.

${ }^{3}$ See above in chapter 2 . 


\section{Voice as object}

Data

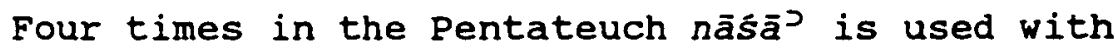
gôl "the voice" as object."

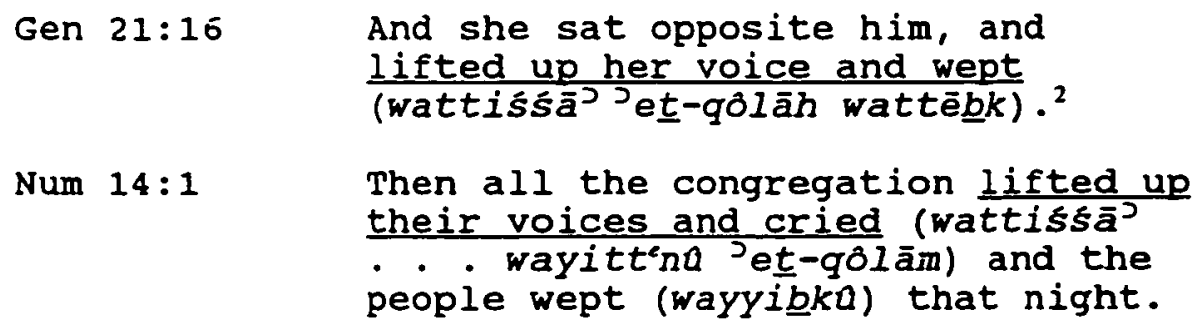

Comments

All of the Pentateuchal passages involving the expression nāsā’ qôl are in non-cultic narratives and the expression is always followed by the sequel bākāh "to weep." 3 In the last passage quoted, nātan is added, apparently to emphasize the intensity of the action. ${ }^{4}$ In all of these passages the subject is "persons," which is $29: 11$.

'This compares to 15 times outside the Pentateuch. ${ }^{2} \mathrm{~A}$ similar expression is found in Gen $27: 38$ and

\footnotetext{
${ }^{3}$ In 10 similar expressions outside the Pentateuch nāsāo qôl leads to "weeping" (Judg 2:4; 21:2; 1 Sam 11:4; $24: 16 ; 30: 4 ; 2$ Sam $3: 32 ; 13: 36$, Job $2: 12$ and Ruth $1: 9$, 14), 4 times to "shouting" (Judg 9:7; Isa 42:2, 11; 52:8), and once to an expression of joy (Isa 24:14).

"For the expression nātan qôl see Gen 45:2 which is the only place where it is followed by a sequel, the prepositional phrase bibkí. Nâtan qôl is found 14 times outside of the Pentateuch, always in a "neutral" sense of making some nondescript sound, frequently a great impressive one such as thunder (1 Sam 12:17, 18) or roaring (Jer $2: 15 ; 22: 20 ; 48: 34$ ).
} 
most frequent, but outside of the Pentateuch the expression is also used of the sound of water.' It appears that the expression nāsā $q 0 \hat{l}$ is an idiomatic expression for the sustained utilization or employment of the sound-mechanism for the purpose expressed by the sequel or context, and is not necessarily an indication of loudness, as most translations seem to imply.

\section{Hand (s) as Object}

Data

Nāsa $\bar{a}^{\supset}$ occurs four times together with yād in the Pentateuch, once in a cultic context with man as subject, and three times in a non-cultic setting with God as subject.

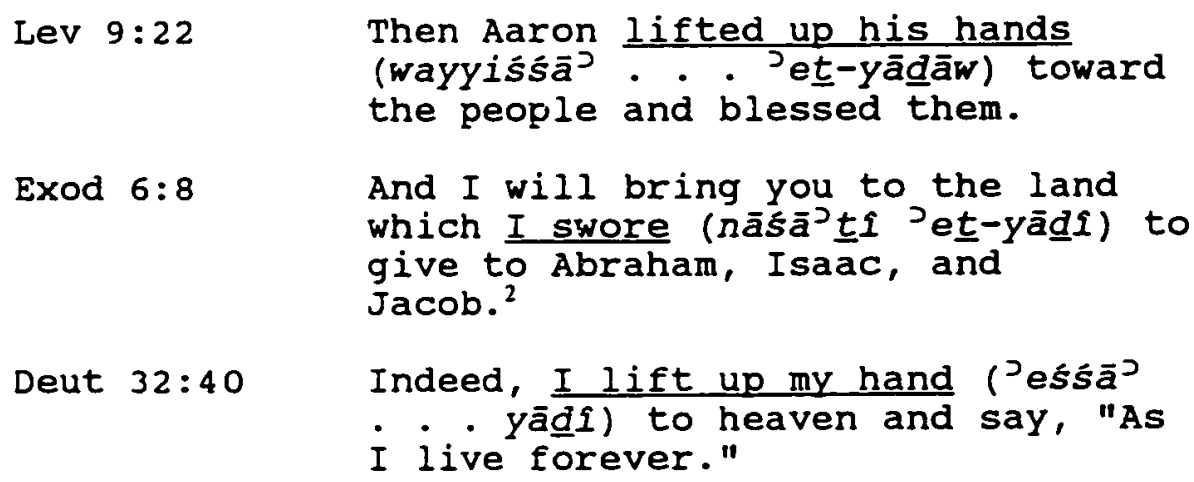

Comments

The expression nāśă $\bar{a}^{\supset} \underline{\underline{d}}$ is used in various contexts in the OT. Within the Pentateuchal corpus,

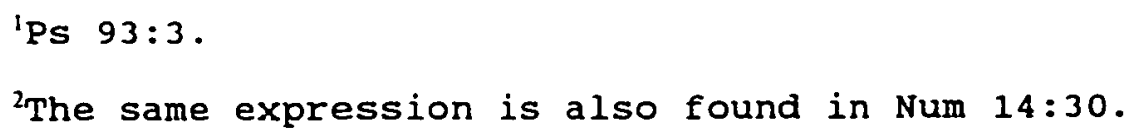


however, it is only used it the context of blessing (once) and swearing an oath, the latter of which is exclusively used with God as the subject.' A parallel expression for man is rum (hiph) and $y \bar{a} \underline{d} .^{2}$ A. D. Crown concurs that the raising of the hand always accompanied the taking of an oath. ${ }^{3}$ But he is wrong when he claims that nāśa ${ }^{2}$ by itself can also mean to swear.' He further believes that this upward movement of the hand may have signified a punishment (e.g., cutting of the throat) in case the oath was broken. This, however, remains a conjecture, since no textual evidence confirms it. More likely is the suggestion by Giesen that the gesture of raising the hand "dürfte affirmativer Art sein."

\footnotetext{
'Freedman and Willoughby--TWAT (1986), 5:640-- give a somewhat misleading impression when they state--quoting a study by Georg Giesen Die Wurzel DJUं "schwören". Eine semasiologische studie zum Eid im Alten Testament, Bonner Biblische Beiträge, Band 56 (Bonn: P. Hanstein, 1981), 43-that "Interessanterweise ist in allem Belegen JHVH subjekt." Giesen makes it clear, however, that this is only in the context where nāśă yăd is used as a "synonym" for šaba $a^{c}$ "to swear." In other contexts man may also be the subject.

${ }^{2}$ E.g. Gen $14: 22$.

${ }^{3}$ Alan D. Crown, "Aposiopesis in the old Testament", Abr-Nahrain 4 (1963-64, ed. 1965):107.

'He quotes $B D B, 670$, but has evidently misread the information given there. BDB does not claim that nāsā by itself means "to swear," but rather in the context of $n \bar{a} \bar{s} \bar{a}^{\supset}$ yãd.

'Giesen, 43. See also Marvin H. Pope, "Oaths", IDB $(1962), 3: 576$.
} 
161

The term for swearing an oath, šăbac, is never used as a sequel for nāsā’ yād even though the idea of oath-taking is quite clear from the immediate context. In these passages it is expressed by the use of the verb nātan. God says that he has "raised his hand (towards heaven)" to give the people the land, etc. When this expression is used of God, in twelve out of fourteen occurrences outside of the Pentateuch it is in the context of God giving a promise.' The other tro simply imply God's lifting his hand for action on behalf of his people.' When used of man, this expression is never associated with oath. Ratran it implies a durative action involving blessing, ${ }^{3}$ prayer or pleadingt, praise or delight ${ }^{5}$, or rebellion. ${ }^{6}$

\footnotetext{
${ }^{\prime}$ Ezek 20:5 (2x), 6, 15, 23, 28, 42; 36:7; 44:12; 47:14; Ps 106:26; Neh 9:15.

${ }^{2}$ Isa $49: 22 ;$ Ps $10: 12$.

${ }^{3}$ Lev 9:22. This is in fact the only Biblical occurrence of nāsā $y^{2} \underline{a}$ in the context of blessing.

${ }^{4}$ Ps $28: 2$; Lam $2: 19$.

${ }^{5}$ PsS $63: 4 ; 119: 48 ; 134: 2$.

${ }^{6} 2$ Sam $18: 28 ; 20: 21$.
} 
Feet as object

Data

The expression nāsāj raglāyw is found only once in

the Pentateuch, and at the same time, in the OT.'

Gen 29:1 Then Jacob went on his journey (wayyiśśă . . ragläyw), and he came (wayyelek) to the land of the sons of the east.

Comments

This is the only occurrence of năša associated with feet in Hebrew. It has led some scholars to question its correctness and suggest emendations. ${ }^{2}$ There is no textual evidence, however, for any different reading, and structurally it is identical with many other expressions involving parts of the body: imperfect with a waw consecutive, subject, object without an object indicator, and a logical sequel which in this case is wayyēlek. Based on the context and parallel expressions, there is no question about its meaning. The expression is ingressive in nature and indicates the decision and act of "taking off" from a place of sojourn.

'A similar expression is found in 1 Sam 17:20 but raglāyw is missing, possibly inadvertently. It may, however, also indicate an idiomatic use of the expression which may lead to the omission of a morph that has "lost" its real meaning.

${ }^{2}$ E.g., Otto Procksch, Die Genesis (Leipzig: A. Deichertsche Verlagsbuchhandlung, 1913), 334 . 
Soul as object

Data

The soul as a mindset is the object of $n \bar{a} \bar{s} \bar{a}^{2}$ in one passage in the Pentateuch. It occurs within the context of laws regulating the way an employer is to treat his employees.

Deut 24:15 You shall give him his wages on his day before the sun sets, for he is poor and sets his heart on it

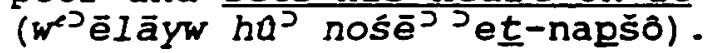

Comments

This expression is found seven times in the OT outside of the Pentateuch.' In the Psalms it is usually translated literally, "I lift my soul." Most commentators and translators make no comments as to its meaning there, but the context implies the idea of "turning one's mind towards" or "keeping one's mind on something" (similar to the last example of nāsā’ cayin above), thus employing the mind, directing it towards something desirable. Outside of the Psalms, it is translated "desire" or "set one's mind to." 12

\footnotetext{
'According to Avraham Even-Shoshan, A New Concordance of the old Testament (Jerusalem: "Kiryat Sefer" Publishing House, 1985), 781, the following: 2 Sam $14: 14 ;$ Pss $24: 4 ; 25: 1 ; 86: 4 ; 143: 8$; Prov $19: 18$; Hos $4: 8$.

${ }^{2}$ Except in 2 Sam 14:14 where it refers to God's taking someone's ife.
} 
In the present passage nāsāj is followed by the preposition ' $e l$, and the idea seems to be "keeping the mind fixed upon" the wages for the day's work. The context seems to imply that it is more than a fleeting thought, it is what the individual lives for at the moment.'

\section{Māsāà as object}

Data

The expression nāsā’ māšăl occurs seven times in the Pentateuch, all in the Balaam corpus. In fact, this expression is not found anywhere in the oT outside of this passage. ${ }^{2}$

$$
\begin{aligned}
& \text { Num 23:7, } 18 \text { And he took up his discourse and }
\end{aligned}
$$

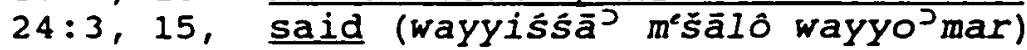

$$
\begin{aligned}
& 20,21,23
\end{aligned}
$$

Comments

$$
\text { All these passages are identical. They form }
$$

intermittant introductions in Balaam's prophetic proclamation. Structurally, they are also identical with those passages where $n \bar{a} \bar{s}^{\prime}{ }^{\supset}$ is used with body parts: the verb nās $\bar{a}^{J}$ in the imperfect, the object without an object indicator, and a sequel.

\section{'LXX translates this expression $\epsilon \nu \alpha \dot{\nu} \tau \varphi \dot{\epsilon} X \epsilon \iota \tau \eta \nu$} $\epsilon \lambda \pi \iota \delta \alpha$ "he has his hope bound up in it."

${ }^{2}$ For similar usage in Akkadian--about the recital of the Enuma Eliš--see chapter 2 above. 
Māsāl is one of those Hebrew words which defy

translation. It is usualiy translated "saying," or

"proverb."l But it has a wider meaning, as EiBfeldt has

pointed out; it involves

auf der einer Seite eine Entwicklung vom einfachen, prosaischen volkssprichwort zum spottvers einerseits und zum poetisch geformten Weisheitsspruch anderseits sieht und auf der anderen Seite Gleichniserzählung, orakelrede und Allegorie in zusammenhang bringt.?

In this context it appears that the expression

means that Balaam employed or utilized "proverbs" as he

spoke, or "he expressed his oracle (instruction) by

saying." The expression does not necessarily imply a loud

Expression, but rather the fact of utilizing a certain

type of expression in his communication.

Heart as subject

Data

The expression combining nāśā’ and lēb is

structurally different from the other expressions

involving parts of the body. In these passages "heart"

functions as subject of the sentences, whereas in all the

others the various body parts have been the objects.

Exod 35:21 And everyone whose heart stirred

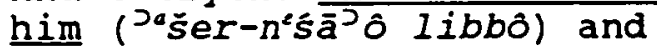

\footnotetext{
${ }^{1}$ Holladay, 219-20.

2Otto Eißfeldt, "Der Maschal im Alten Testament," Zeitschrift für die alttestamentliche wissenschaft, Beihefte 24 (1913), 42; quoted in Karl-Martin Beyse, "סט לס " māšal I," TWAT 5:72.
} 
everyone whose heart moved him

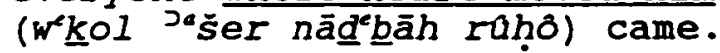

Exod $36: 2$

Then Moses called. . everyone whose hearl stirred him (KOI Jašer $n^{e} \bar{s}^{\top} \bar{o}$ libbo), to come to work to perform it.

Exod 35:26 And all the women whose heart stirred ("šer năsă libban) with a skill.

Comments

The context indicates that the meaning of all of them is quite similar, "Every man/woman whose heart stirred him/her" to perform a particular task came forward and did his/her share in connection with the construction of the tabernacle. In light of the context and other parallel passages it appears that these individuals were endowed with a special skill which they felt motivated to employ for the purpose of setting up the tabernacle and its equipment.

This is in line with other passages where nāsa $\bar{a}^{2}$ is used in expressions involving parts of the body as objects. In these, it forms a part of an idiomatic expression implying the utilization of that part or object for some stated purpose, rather than being just a description of an actual movement. The action may involve

'See e.g., Exod 35:22, 25, 29; 36:4. The Syriac version, Peshitta, translates this expression with tḥsb blbh meaning "purpose/plan/have in mind in his/her heart," possibly implying creativity [?]. 
the movement of a particular body part, but it is not synonymous with it; rather it is the result of the employment of that organ.

\section{Summary}

Based on the general usage of $n \bar{a} \bar{s} \bar{a}^{2}$ in the Pentateuch the basic idea that emerges is one of sustained carrying with the aspects of transport and/or support being indicated by prepositions, morphs of movement, parallel expressions and/or the immediate context. Its meaning may also be "carried out" by various body parts or by means of tools being utilized for a specific purpose related to their functionality. In more than 40 percent of occurrences within the Pentateuch the emphasis is on the aspect of lifting, whereas in the remaining 60 percent the main emphasis is on the carrying aspect, even though lifting may be involved.

These shades of meaning are not discernible in any form of the root itself, but are indicated by certain morphs, parallelisms, or, most importantly, the context. The Pentateuchal usage seems to support the contention that nāsà does not primarily describe a momentary movement, but rather a prolonged support. Even when a movement is involved, it either presupposes support (as in the idea of transport) or implies duration (as in the context of utilization). With body parts or tools the 
nāsāo expression is followed by a sequel, which expresses the purpose or result of the action rather than being a synonym.

With this background we now turn the attention to the more metaphoric use of tine root and investigate how it is used in the context of wrongdoings. 


\title{
CHAPTER V
}

\section{$N \hat{S}^{\supset}$ AND WRONGDOING IN THE PENTATEUCH}

\begin{abstract}
The remaining sixty-one occurrences of the root $n \bar{a} \bar{s}^{2}$ in the Pentateuch are in the context of interpersonal relations and/or sin and wrongdoing within which sphere the concept of forgiveness is found. The attention in this chapter is directed towards the thirty-nine passages which use nass $\bar{a}^{2}$ in the context of sin and wrongdoing. The remaining twenty-two passages, involving interpersonal relations, are the subject of chapter 6 .
\end{abstract}

\section{Nāśa $\bar{a}^{J}$ and Wrongdoing}

When $n \bar{a} \bar{s}^{2}{ }^{\supset}$ is used with terms for sin and/or wrongdoing the main concern is not the transport or removal of the wrong per se, but rather the consequences resulting from who is carrying the wrongs. On the one hand, there are those who nāśa $\bar{a}^{\supset}$ their own wrongdoings, and then there are those who nāsāj the wrongs of others. In only eight out of thirty-nine instances is nāsā followed by the preposition 'ăl which three times indicates cause,'

\footnotetext{
${ }^{1}$ Lev $22: 9 ; 19: 17 ;$ Num $18: 32$.
} 
four times it implies movement,' and once the positional effect is reinforced by $\mathrm{J}_{e l}$ and a directional $-\bar{a} h .^{2}$

$$
\begin{aligned}
& \text { Nāśā and Own Wrongdoings } \\
& \text { There are nineteen passages in the category of }
\end{aligned}
$$
nās $\bar{s}^{2}$ in the context of own wrongdoings. Only three of these have a preposition, $\varsigma_{\bar{a}} \mathbf{l}$, which indicates cause in these contexts. ${ }^{3}$ All of them have human beings as subject and ‘ āwôn, or ḥẹt ${ }^{\supset}$ as objects: ‘āwôn 12 times, and ḥẹt’ 7 times. of these, two passages deal with wrongdoing in general (1), six are related to cultic eating (2), one is associated with cultic clothing (3), four deal with sexual relations (4), four with attitudes and actions towards God or holy things (5), and two indicate attitudes and actions toward a fellow human being (6).

\section{Data}

1. Wrongdoing in general

Lev $5: 1$

Now if a person sins. . when he is a witness.. he will bear his guilt (wenāśẳ Caônô).

Lev $5: 17$

$$
\begin{aligned}
& \text { Now if a person sins. - though } \\
& \text { he was unaware, still he is guilty, } \\
& \text { and he shall bear his punishment } \\
& \text { (w'nāsáa câonô). }
\end{aligned}
$$

\footnotetext{
'Exod 28:12, 29, 30, 38.

${ }^{2}$ Lev 16:22. Cf. also vs. 21 .

${ }^{3}$ Lev $17: 17 ; 22: 9 ;$ Num $18: 32$. See Waltke, 218 .
} 
2. Cultic eating

Lev $7: 18$

The person who eats of it [the Peace offering on the third day] shall bear his own iniquity

Lev $19: 8$

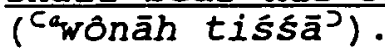

Lev $22: 16$

And everyone who eats it [same as in $7: 18$ ] will bear his iniquity ("wônó $y \overline{i s ́ s} \bar{a}^{2}$ ) for he has profaned the holy thing of the Lord; and that person shall be cut off from his people.

(And they shall not profane the holy gifts of the sons of Israel which they offer to the Lord,) and so cause them to bear punishment for quilt (whiśsi'a 'otām Cwôn ašmāh) by eating their holy gifts.

Lev $22: 9$

They [the priests] shall therefore keep my charge, so that they may not bear sin because of it ( $w^{2}-$

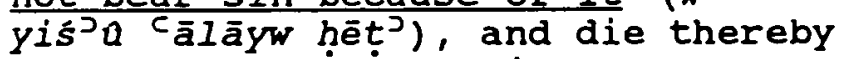
because they profane it.

Num $18: 32$

And you shall bear no sin by reason of it ( $w^{2} 10^{2}-t i \bar{s}^{2} a$ calayw hẹt $\left.{ }^{2}\right)$, when you have offered the best of it [the harvest].

Lev $17: 16$

But if he does not wash them [his clothes after eating anything found dead] or bathe his body, then he shall bear his quilt ( $w^{\prime} n \bar{a} \bar{s} \bar{a}^{3}$ câôno).

3. Cultic clothing

Exod $28: 43$

They [the linen breeches] shall be on Aaron and on his sons when they enter the tent of meeting, . . so they do not incur quilt ( $w^{2} 10^{2}-$

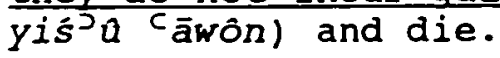

\footnotetext{
'Referring to touching unclean things or eating
} sacred offerings without bathing. 
4. Sexual relations

Lev $20: 17$

If there is a man who takes his sister.. . so that he sees her nakedness . . . it is a disgrace; and they shall be cut off in the sight of the sons of their people. He has uncovered his sister's nakedness; he shall bear his guilt

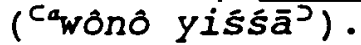

Lev 20:19

Lev $20: 20$

You shall not uncover the nakedness of your mother's sister... they shall bear their guilt ( ${ }^{C a}$ wônàm yiśsããa).

Num $5: 31$

If there is a man who lies with his uncle's wife. . they shall bear

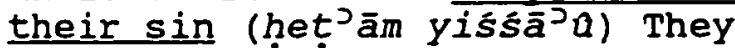
will die chilláless.

Moreover, the man [who is jealous because his wife Nas unfaithful] shall be free from guilt but that woman shall bear her guilt (tiśsā? Jet Ca (wônăh).

5. Attitudes and actions towards God and holy things

Lev $24: 15$

If anyone curses his God, then he shall bear his sin (wonásáa het ${ }^{2} \delta$ ).

Num $14: 34$

For every day you shall bear your

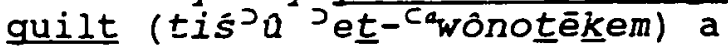
year.

Num $18: 22$

And the sons of Israel shall not come near the tent of meeting again, lest they bear sin (Iấs $\bar{e}^{\top} \underline{t}$ hẹt $t^{2}$ ) and die.

Num $9: 13$

The iian who . . . neglects to observe the Passover, that person shall be cut off from his people. - . That man shall bear his sin (het ${ }^{j} \hat{o}$ yiśs̄à $)$.

6. Attitude and actions towards others

Lev $19: 17$

You shall not hate your fellow country-man in your heart; you may 
surely reprove your neighbor, but shall not incur quilt because of

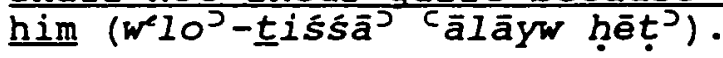

Gen $4: 13$

And Cain said to the Lord, My punishment is too great for me to

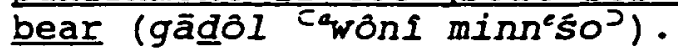

\section{Comments}

All but two of these passages, Num $14: 34$ and Gen 4:13 which are in narrative texts, are in a cultic setting--regulations as to what will happen if individuals should do or fail to perform certain actions. These vary from defiance of God and holy things,' failure to observe cultic rituals ${ }^{2}$ to obstinacy, ${ }^{3}$ immoral acts and hate of one's fellow man, or plain ignorance." All of them lead to the same result: whoever commits the acts mentioned, either knowingly or inadvertently, has to nāsaj his or her own wrongdoing. This wrongdoing may be expressed by either 'āwon or hẹt', which are used quite interchangeably in these contexts. ${ }^{6}$

'Gen $4: 13 ;$ Lev $24: 15$ and Num $18: 22$.

${ }^{2}$ Exod 28:43; Lev $7: 18 ; 9: 13 ; 17: 16 ; 19: 8 ; 22: 9,16$; and Num $18: 32$.

${ }^{3}$ Lev $5: 1 ;$ Num $5: 31 ;$ and $14: 34$.

${ }^{4}$ Lev $19: 17$ and $20: 17,19,20$.

${ }^{5}$ Lev $5: 17$.

${ }^{6}$ For an extensive discussion of the difference between these terms and their use, see R. Knierim, passim. In this context, however, we find illicit sexual relations classified as 'ầôn in jev 20:17-19 but as hẹt ${ }^{\text {' }}$ in vs. 20 . 
Besides, there is no clear distinction to be found between action and its consequences. The difference is more a matter of interpretation than one of direct translation. Von $\mathrm{Rad}^{1}$ has also pointed out that "there is absolutely nothing in the thought of the OT which by and large corresponds to the separation which we make between sin and penalty," and again, that there is no difference between the guilt of the deed and its penalty. The concept includes both the act and its consequences. This concept he calls "Tatsphäre" or "a synthetic view of life." 2

The same ambivalence is also found in relation to touching unclean things in Lev 22:9 (hẹt't) and 17:16 ('āwôn). Whatever shade of meaning may be involved does not appear to affect the nāsáa action. Translations attempt to relate the action to modern equivalents or counterparts

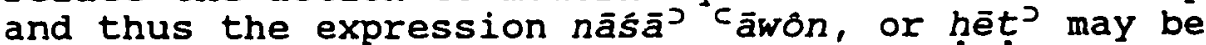
translated as bearing one's iniquity/sin/guilt/punishment or responsibility. This apparent inconsistency is found both within a given translation and also between different translations. In the texts under discussion nāsāj cāwôn is translated "bear guilt" in Lev 5:1; 17:16; 20:17-19; Num $5: 31$ and $14: 34$ "bear iniquity" in Lev $7: 18$ and $19: 8$ and "bear punishment" in Gen $4: 13$, Lev $5: 17 ;$ and $22: 16$. At the same time nāsáa hēt is translated as "bear sin" in Lev $20: 20 ; 22: 9 ; 24: 15 ;$ Num $9: 13 ;$ and $18: 32 ;$ but "incur guilt" in Lev 19:17. As an example of how different

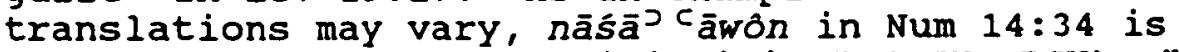
translated as "bear your iniquities" (KJV, RSV), "bear your guilt" (NASB), "pay the penalty of your iniquity" (NEB) and "suffer for your sins" (NIV). On this point see also Knierim, 219-221.

'von Rad old Testament Theology, 1:266.

I'Ibid. , 265. 
The composite picture emerging from these texts is that of one who has committed some wrong acts against God, his instructions or a fellow man, and as a consequence must bear/carry the effects of his/her actions involving the "Eingeständnis eigener Schuld und Einsicht in die Strafe."l Nās̄ā’ Cāwôn/ḥẹt’ in these contexts indicates the individual's responsibility for his actions, and according to the judicial principle of action-consequence relationship in Israel, the sinner must stand up to his own actions. ${ }^{2}$

The exact consequences are not always explicitly expressed, as can be seen in table 20. In the first group of texts (1) dealing with failure to testify or doing what is expressly forbidden, there are no stated consequences; only a general statement to the effect that the wrongdoer will be held accountable for his actions. Unacceptable cultic eating (2) usually led to death: "he shall die,"3 "be cut off," non-acceptance and death, 5 or, no explicit $5: 633$.

'Freedman and Willoughby, "nāśā'," TWAT (1986),

${ }^{2}$ Ibid., 634

${ }^{3} \mathrm{Num} 18: 32$.

t'Lev $19: 8 ; 22: 9 ; 17: 16$.

${ }^{5}$ Lev $7: 18$. Cf. 19:8 which deals with the same offering. 
TABLE 20

Nāsā’ OWN WRONGDOINGS

\begin{tabular}{|c|c|c|c|}
\hline căwôn & subject & Wrongdoing & Effect (implied) \\
\hline $\begin{array}{l}\text { Gen } 4: 13 \\
\text { Exod } 28: 43\end{array}$ & $\begin{array}{l}\text { Cain } \\
\text { Aaron/sons }\end{array}$ & $\begin{array}{l}\text { murder } \\
\text { improper clothing in } \\
\text { tabernacle }\end{array}$ & $\begin{array}{l}\text { death cf. 4:15 } \\
\text { death }\end{array}$ \\
\hline $\begin{array}{l}\text { Lev } 5: 1 \\
\text { Lev } 5: 17\end{array}$ & $\begin{array}{ll}1 & 1 \\
1 & 1\end{array}$ & $\begin{array}{l}\text { wrong witnessing } \\
\text { general failure }\end{array}$ & \\
\hline $\begin{array}{l}\text { Lev } 7: 18 \\
\text { Lev } 19: 8\end{array}$ & $\begin{array}{ll}1 & 1 \\
1 & 1\end{array}$ & $\begin{array}{l}\text { wrong eating of offering } \\
\text { wrongful eating } \\
\text { of sacrifices }\end{array}$ & $\begin{array}{r}\text { (death cf. } \\
7: 20,21 \text { ) } \\
\text { cut off from } \\
\text { the people }\end{array}$ \\
\hline $\begin{array}{l}\text { Lev } 22: 16 \\
\text { Lev } 17: 16 \\
\text { Lev } 20: 17 \\
\text { Lev } 20: 19\end{array}$ & $\begin{array}{l}1 \\
1 \\
\operatorname{Man} \\
\operatorname{Man}\end{array}$ & $\begin{array}{l}\text { wrongful eating } \\
\text { of sacrifices } \\
\text { incest } \\
\text { incest }\end{array}$ & $\begin{array}{l}\text { (death cf.22:9) } \\
\text { (cut off cf. } \\
17: 14 \text { ) } \\
\text { cut off } \\
\text { (cut off } \\
\text { cf. } 18: 29 \text { ) }\end{array}$ \\
\hline $\begin{array}{l}\text { Num } 14: 34 \\
\text { Num } 5: 31\end{array}$ & $\begin{array}{l}\text { People } \\
\text { Wife }\end{array}$ & $\begin{array}{l}\text { rebelition } \\
\text { unfaithfulness }\end{array}$ & $\begin{array}{l}\text { death cf. } 14: 35 \\
\text { (death cf. Deut } \\
22: 22 \text { ) }\end{array}$ \\
\hline \multicolumn{4}{|l|}{ he t? } \\
\hline $\begin{array}{l}\text { Lev } 22: 9 \\
\text { Lev } 20: 20 \\
\text { Lev } 24: 15 \\
\text { Lev } 19: 17 \\
\text { Num } 18: 22 \\
\text { Num } 9: 13 \\
\text { Num } 18: 32\end{array}$ & $\begin{array}{l}\text { Priests } \\
\text { Man } \\
\left(\begin{array}{l}) \\
( \\
( \\
( \\
\text { Levites }\end{array}\right.\end{array}$ & $\begin{array}{l}\text { eating sacrifice } \\
\text { without washing } \\
\text { incest } \\
\text { cursing God } \\
\text { hating fellow countryman } \\
\text { approach tent of meeting } \\
\text { neglect passover } \\
\text { wrongful eating harvest }\end{array}$ & $\begin{array}{l}\text { death } \\
\text { death w/o child } \\
\text { death } \\
\text { death } \\
\text { death } \\
\text { death }\end{array}$ \\
\hline
\end{tabular}


consequences when eating sacred offerings by mistake.' A Levite not wearing breeches as he served in the Tabernacle must die. ${ }^{2}$ Any kind of illicit sexual relations usually led to death to both persons involved. 3 If a man had sexual relations with his uncle's wife, the law demanded that both the man and the woman be put to death without the relationship bearing fruit--i.e., without a child born as a result; they would "die childless." In the case of an unfaithful wife, the context indicates some devastating

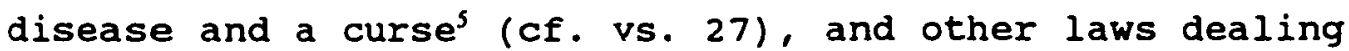
with similar cases indicate that these might ultimately be fatal. Open or indirect obstinacy and rebellion against God and his holy requirements were all punishable by

${ }^{1}$ Lev $22: 16$. Cf. however $22: 9$.

${ }^{2}$ Exod $28: 43$.

${ }^{3}$ Lev $20: 17,20$.

${ }^{4}$ Lev 20:19. The same is said about sexual relations between in-laws in vs. 21. It is not clear if the expression only implies inability to bear children or if it is another way of saying that their effort to have children together will be fruitless for they shall both die. In light of the general context the latter seems more likely. Norman H. Snaith, ed. Leviticus and Numbers, Century Bible (London: Thomas Nelson \& Sons, 1967), 140, points out that the root ${ }^{C a}$ ririm actually means "stripped," and probably implies that the "couple" would be "stripped of posterity" to keep the family name in remembrance. This would then also mean that they would have no place in genealogies or in continuing Israel.

${ }^{5}$ Num $5: 31$.

${ }^{\circ} \mathrm{Cf}$. Deut 22:22 where both the man and the woman are to die if they are caught. 
death, either immediate ${ }^{1}$ or ultimate. ${ }^{2}$ Finally, hate and murder both ultimately resulted in death. ${ }^{3}$

According to these passages the ultimate consequence of wrongdoing is death. It is an unavoidable burden which the wrongdoer must carry. "Die Schuld liegt wiet eine Last auf dem Menschen . . die man tragen und auf sich nehmen. . muß."s

Knierim appropriately likens the 'āwôn to a

lebendig wirksame Last, auf jedem Fall zu tragen, und zwar so lange, bis er seiner Qualität gemäB dem Täter zum entsprechenden Schicksal geworden und damit zum Ziel, zur Erfüllung gelangt ist. Ist der Täter tot, so ist auch der 'āwôn aus der Welt geschafft. Er geht nicht verloren und wird nicht vergessen. Und hat er einmal begonnen, so muB er auch getragen werden. Naheliegend ist, daB ihn der Täter selbst zu trágen hat, und ebenso, daB er inn nicht tragen vermag (Kain). ${ }^{6}$

Such severe consequences, and the fact that it is difficult to live without ever taking a faulty step lead inevitably to the question, whether the wrongdoer is entirely left to his fate, without any hope of respite.

'Lev 24:15; Num $9: 13 ;$ and $18: 22$.

${ }^{2}$ Num $14: 34$.

${ }^{3}$ Lev $19: 17$ and Gen $4: 13$.

"Knierim, 221, note 89, suggests to "emend" this by reading "als" instead of "wie" in order to emphasize the concretization of the acts and their consequences.

sotto Procksch, Theologie des Alten Testaments (Güterloh: C. Bertelsmann Verlag, 1950), 637 .

oKnierim, 221. 
Nāśā and Wrongdoings of Others

There are indications, however, that these severe burdens need not be borne by the wrongdoer alone. In eighteen passages in the Pentateuch someone other than the wrongdoer is either asked or said to näs $\vec{a}^{\supset}$ the wrongs. In thirteen of these man is the subject; in four, God or a divine being; and an animal, in one. While the distinction between bearing/carrying and transport/ movement is somewhat blurred, it is of interest to note that in five out of eight cases where movement appears to be emphasized' we find the preposition 'al. The preposition, however, is not indicating a movement but rather a position. The movement itself is found in the context. It is of interest to note that in the case of the goat for Azazel an unambiguous preposition of movement, ${ }^{2} e l$, is used and reinforced by a directional $-\bar{a} h .^{2}$ In one text a movement is implied without any morph to indicate it. ${ }^{3}$ The remaining twelve passages have no preposition of indication, but the context of all but three of them implies the idea of "bearing:" or "sustaining." The wrongs may be indicated by either cāwón, $z^{\prime} n u \underline{t}$, semôt/ mišpaț, hẹt ${ }^{\supset}$ or pešac, which appear to be

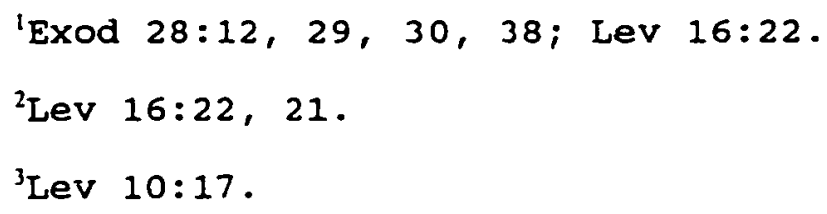


used mostly synonymously, without any clear distinction between them in these contexts.

\section{Man as Subject}

There are eleven passages with a total of thirteen occurrences of nāsāj in which man is the subject. Six passages, with seven occurrences--all of which convey the idea of "bearing" or "carrying"--deal with the duties and functions of the priests and Levites in the sanctuary (1), one is also related to a priestly function in the sanctuary, but emphasizes more the aspect of "transporting" or "removing" by eating (2), one deals with a transfer of responsibility when a vow is cancelled (3), and finally, three passages, with four occurrences of nāșáp, are in the context of general wrongdoing against an individual, a group of people, or God (4). Two of them, with three occurrences, imply "transport" or "moving," whereas one has the idea of "bearing" or "suffering." All the passages are in a cultic context except those in group (4) which are narrative.

Data

1. General functions of priests

Num 18:1 You and your sons and your father's household with you shall bear the quilt ( $t i \bar{s}^{\supset} a$ Jet-cwôn hammiqdāśs) in connection with' the sanctuary;

'The Hebrew does not have the expression "in 
Num $18: 23$

Exod $28: 12$

Exod $28: 29$

Exod $28: 30$

Exod $28: 38$ and you and your sons with you shall bear the guilt ( $t$ is $^{\supset} 0$ ' et"wôn k'hunnat'kem) in connection with your priesthood.

only the Levites shall perform the service of the tent of meeting, and they shall bear their iniquity

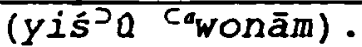

And you shall put the two stones on the shoulder pieces of the ephod, as stones of memorial for the sons of Israel, and Aaron shall bear their names ( $w^{e} n \bar{a} \bar{s} \bar{a}^{3}$. . . Tets'môtām lipnê yhwh) before the Lord on his shoulders for a memorial.

And Aaron shall bear the names

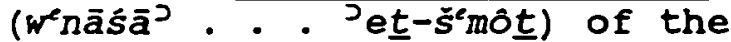
sons of Israel in the breastplate of judgment over his heart when he enters the holy place, for a memorial before the Lord continually.

And you shall put in the breastplate of judgment the Urim and Thummim, and they shall be over Aaron's heart when he goes before the Lord; and Aaron shall carry the judgment (wonass $\bar{a}^{2}$. . ' 'et-mišpaț) of the sons of Israel over his heart before the Lord continually.

And it [the plate of gold] shall be on Aaron's forehead, and Aaron shall take away the iniquity

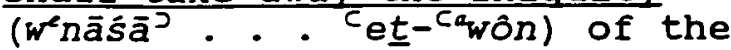
holy things which the sons of Israel consecrate, with regard to all their holy gifts; and it shall always be on their forehead, that

connection with" which appears twice in this passage, thus actually it should be in italics. This translation is probably chosen to avoid associating the holy place with guilt and wickedness. The Hebrew text has only "cāwón of the sanctuary" and "Cāwôn of your priesthood." 
they may be accepted before the Lord.

2. Transport by eating

Lev $10: 17$

Why did you not eat the sin

offering in the holy place? For it

is most holy, and he gave it to you to bear away the guilt ( $I \bar{a} s \bar{e}^{2} t$ ) etcowôn) of the congregation, to make atonement for them before the Lord.

3. Cancelled vow

Num $30: 15$

But if her husband annuls them [vows made by his wife] after he has heard them, then he shall bear her quilt (wonāsāa J et-Câônāh).

4. General wrongdoing

Gen 50:17

Thus you shall say to Joseph, Please forgive, I beg you, the

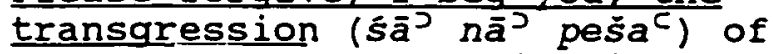
your brothers and their sin, for they did you wrong. And now, please forgive the transqression

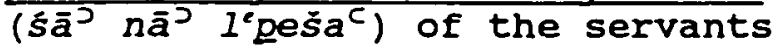
of the God of your father. And Joseph wept when they spoke to him.

Exod 10:17

Now therefore, please forgive my sin ( $\bar{s} \bar{a}^{2} n \bar{a}^{\supset}$ hatt $\bar{a}^{2} t \hat{l}$ ) only this once, and make supplication to the Lord your God, that He would only remove this death from me.

Num $14: 33$

And your sons shall be shepherds for forty years in the wilderness, and they shall suffer for your unfaithfulness ( $w^{\prime} n \bar{a} \bar{s}^{2} a$ 'et$z^{e}$ nutêkem), until your corpses lie in the wilderness.

Comments

In the first two passages, Num $18: 1$ and 23, the fundamental duties of Aaron and his sons are being pointed 
out by the Lord, on the one hand, and those of the Levites in general, on the other. Aaron and his sons were told that it was their duty to nāsā' the 'āwon of the sanctuary and the priesthood.

Knierim sees this text indicating that the priests and Levites were to bear the ${ }^{\complement} \bar{a}$ won of every conscious and unconscious act done by the people against the sanctuary or the priesthood.' Contextually, these verses come as a direct response to the problem expressed in 17:13 following the experience of Korah's challenge of Moses' and Aaron's leadership roles. In his understanding all were equally holy to serve before the Lord (cf. 16:1-3). When the people saw God's conclusive answer, they became frightened and asked in effect, "What is the point in having the tabernacle of God in our midst if no one can approach it, lest he die?" In order to prevent the people from treating God as their equal, God indicated to them that they must keep their distance, but that he (God) had already made provision to maintain a close relationship anyway. The Levites had been appointed to guard against possible trespassers among the people $(18: 3,4)$. In the same way, the priests had been appointed to guard against possible trespassers among the Levites who were not to perform certain priestly tasks. The priests were

\footnotetext{
'Knierim, 242.
} 
responsible for enforcing this rule. They were thus to act as spiritual "lightning conductors" for God's anger so the people might be spared.'

Philip J. Budd takes a somewhat broader view when he sees the priests paying "the penalty for all ritual errors" thus indicating that "the priests are fully responsible for the sanctuary, and for every aspect of priestly ministry."2 or, in the words of $J$. de vaulx,

Les prêtres, responsables du culte, serviteurs de l'autel et du Saint de Saints ( $v .3,7)$ et les lévites, serviteurs du sanctuaire ( $v .3,4,5,6$ ), sont en même temps protecteurs de la communauté ( $v$. 27) puisque par leur intermédiaire, strictement hiérarchisé, s'établissent des relations acceptables entre les Fils d'Israël et le Dieu très saint, auprès duquel tous sont des étrangers hormis ceux qu'Il a choisis. Telle est finalement la raison d'être du Sacerdoce et du lévitisme. ${ }^{3}$

still others see this passage expressing the concept that the priests and the Levites were to bear, or

'Gordon J. Wenham, Numbers (Downers Grove:

Intervarsity Press, 1981), 143. The same idea is also expressed by Jacob Milgrom in his studies in Levitical Terminology, vol. 1 (London: University of California Press, 1970), 31, and "The Literary Structure of Numbers 8:5-22 and the Levitic Kippar" in, Perspectives on Lanquage and Text, ed. Edgar W. Conrad and Edward G. Newing (Winona Lake: Eisenbrauns, 1987), 211-228; see also George B. Gray, A Critical and Exegetical Commentary on Numbers (Edinburgh: T. and T. Clark, 1956), 219; and Norman H. Snaith, ed. Leviticus and Numbers, CBC (Iondon: Thomas Nelson \& Sons, 1967), 205. In this context Whybray, 44-45, is willing to concede the idea of substitution, even though he argues against it in general.

${ }^{2}$ Philip J. Budd, Numbers, WBC (Waco: Word Books Publishers, 1984), 5:205.

${ }^{3} \mathrm{~J}$. de Vaulx, Les Nombres (Paris: Libraire Lecoffre J. Gabalda et Cie Editeurs, 1972), 204 . 
take upon themselves, and expunge the guilt brought upon the sanctuary by the sins of the people and their holy gifts (cf. Exod 28:38), "contaminated" by the sinfulness of the givers. ${ }^{1}$

This interpretation seems to be confirmed by the next four passages from Exod 28, which are concerned with different parts of Aaron's garments and their function in the sanctuary ritual. In vs. 12 there are two stones "engraved according to the names of the sons of Israel" and were placed on Aaron's shoulders. Vs. 29 mentions the breastplate, on which stones were placed, one for each of the tribes with engravings according to their names. The purpose of these was that Aaron might "bear their names" on his shoulders and on his heart as he entered the presence of the Lord. In this way he would be their representative/substitute within the holy area of the sanctuary. ${ }^{2}$

on the surface, these texts do not deal with any kind of wrongdoing, but the whole context of chap. 28 in general and vss. 30 and 38 in particular clearly indicate that this nāsā? process is related to the people's

\footnotetext{
'So Keil and Delitzsch, 3:115-16. The context, however, seems to imply that primarily they were responsible for the actions of those "employed" in the sanctuary precinct.

${ }^{2}$ See Keil and Delitzsch, 2:195; and R. Alan Cole, Exodus (Downers Grove: Inter-Varsity Press, 1977), 200.
} 
wrongdoing. Vs. 30 speaks of the Urim and Thummim in the breastplate, and vs. 38 is concerned with the goldplate on Aaron's forehead. The function of the former is for Aaron to "bear the judgments" of the people over his heart, 2 and that of the latter so that he might "bear their iniquity" in before the Lord. In light of von Rad's synthetic-view-of-life approach ${ }^{3}$ these two phrases are parallel if not completely synonymous. Judgment is the result of the iniquities and the iniquities are the cause of the judgment. The strategic placement of the stones

'On the puzzling nature of the Urim and Thummim see Edward Robertson, "The Urim and Thummim; What Were They?" VT 14 (1964), 67-74, and Edward Lipinski, "Urim and Thummim" VT 20 (1970), 495-6. Further, on the issue of Urim and Thummim, Keil and Delitzsch conclude, however, quite correctly that "we can draw no other conclusion, than that the Urim and Thummim are to be regarded as a certain medium, . . through which, whenever the congregation required divine illumination to guide its actions, that illumination was guaranteed." 2:199. Robertson $(69,70)$ lists a dozen different interpretations of Urim and Thummim before adding his own suggestion that probably they represented the Hebrew alphabet "which could be used as elements of writing." He comments further that as these two names begin with the first and the last letters in the Hebrew alphabet, they possibly indicate God's universality, similar to the expression Alpha and Omega in the book of Revelation. He finds support for this in the DSS where there are several occurrences of a word apparently coined by fusing the two into ${ }_{\text {wrtwm }}$ believed to mean "fulness" ( $p .72$ ) parallel to the expression "alpha and omega" in the New Testament. Based on Mesopotamian parallels Lipinski (496) prefers to see them as some magic stones which somehow "gave a (yes) or (no) answer."

${ }^{2}$ Compare the function of the stones in vs. 29 .

${ }^{3}$ von Rad, old Testament Theology, 1:265. 
and goldplate was apparently an outward, visible indication of Aaron's identifying himself in heart and mind with the people and their wrongdoings as he prepared to enter the presence of the Lord on their behalf. BY means of these pieces of his vestments he symbolically carried ( $n \bar{a} \hat{s}^{2}$ ) their wrongdoings and judgments on his body. He was not just a detached representative of the people; he identified himself completely with them before he entered the presence of the Lord.'

with regard to the goldplate on the forehead, the inscription on it designated the high priest as the Lord's possession, consecrated to the Lord (vs. 36). Aaron was told to wear it in order to nāsā? the căwon of the people into the sanctuary, as they were being brought to the tabernacle with the gifts which the people had set apart for that purpose. ${ }^{2}$ By accepting these gifts Aaron also

\footnotetext{
'So Willem H. Gispen, Exodus, trans. Ed. van der Maas (Grand Rapids: Zondervan Publishing House, 1982), 272, and Cole, 200. Ehrlich, 1:376-7, on the other hand, sees these texts more in line with Num 18:1 which places on the priest "die Verantwörtlichkeit.. . für irgend welche verfehlung hinsichtlicher Heiligtümer JHVHs." The context, however, seems rather to refer to the priest's taking the guilt and wrongs of the people upon himself than wrongs being committed to the sanctuary. Cf. also the NT image of Christ, of whom the Levites in general and the highpriest in particular were a type, who is presented as "bearing our sins in his body on the cross" ( 1 Pet $2: 21-24$ ).
}

${ }^{2}$ Exod $28: 38$. 
accepted what they stood for,' and symbolically he carried the wrongdoings of the people on his body in before the Lord.2 Rodriguez has pointed out that the headpiece was connected with the priest's bearing the sins of the people and the people's acceptance before the Lord. These are closely interrelated.

The sys becomes a symbol of that acceptance, and of that which enables Aaron to bear sin; i.e. holiness. It is because he has been separated for the Lord that he can bear the sin of the sacrifices. ${ }^{3}$

The diadem, or headpiece, thus signified the mediating aspect of the high-priestly office as well as its substitutionary character.4

'Cf. Num 18:1 above, where Aaron and his sons are made responsible for the 'awon of the sanctuary and the priesthood; also vs. 23 where it is stated that the function of the Levites--of whom Aaron was the epitome-was to bear the iniquity of the people.

${ }^{2}$ See vss. 30 and 38 .

${ }^{3}$ Angel M. Rodriguez, Substitution in the Hebrew Cultus, Andrews University Seminary Doctoral Dissertation Series, vol. 3 (Berrien Springs, MI: Andrews University Press, 1979), 134 .

'Gispen, 272. The fact that one who was both identified with the people and also set apart to serve before the Lord was carrying the gifts of the people as their substitute into his presence made them, i.e. the people--the pronoun is masculine singular referring back to "sons of Israel," whereas "gifts" is feminine plural-acceptable in the Lord's sight. This concept is also in line with Isa 53 where the "servant" is set apart to take upon himself the wrongs of all, carry (nāsā') them through piercing afflictions and death, thereby obtaining for the people acceptance or justification. 
This interpretation appears to be further confirmed by the process of the priest's eating a portion of the sin-offering. In Lev 10:17 Moses rebukes Eleazar and Ithamar, sons of Aaron, for not correctly performing their priestly duties. They had failed to eat of the sin offering, as required by the law of the sin offering in Lev 6:26, and had burned it instead. Ehrlich suggests that

wenn nicht Gott, sondern der Priester Subject ist, heisst immer, ohne Ausnahme, für das Vergehen eines andern gegen die Heiligtümer verantwortlich sein.'

It seems, however, that the text implies an even deeper sense than simplÿ a responsibility for the wrongs committed by the people. In Near Eastern cultures eating had the symbolic overtones of acceptance and/or relationship or even identification with someone. ${ }^{2}$ The same appears to be the case here. The "goat of sin"

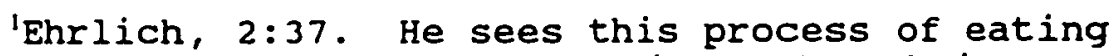
merely as God's payment to the priests for their responsibility. "JHWH gibt den Priestern ihre Deputate vom Opfertier als Lohn, gagen sie die genannte verantwortlichkeit und die Dienste am Heiligtum übernehmen."

${ }^{2}$ See Johannes Pedersen, Israel: Its Life and culture, 2 vols. (London: Oxford University Press, 192640), 305. In the Bible it is perhaps most explicit in the eucharistic eating and drinking of the bread and wine, an act signifying the participants' sharing or identifying with Jesus, the true bread and wine, in his life and death (cf. John 6 and 1 Cor 10:16,17). See also Geoffrey Wainwright, Eucharist and Eschatology (London: Epworth Press, 1971), especially pp. 18-19, and harold H. Rowley, Worship in Ancient Israel: Its Forms and Meaning (London: SPCK, 1967), 123-25.
} 
( $s^{e c}$ ir hahatt $\bar{a}^{2} \underline{t}$ ) carried the sins of the confessor.' When the priest ate of that offering he symbolically made it a part of himself, in the same way as food becomes a part of its "eater" (along with all its "liabilities" like disease et al.), and took upon himself its function to nāss $\bar{a}^{2}$ the wrongs of the people into the sanctuary for the purpose of making an atonement for ( $1^{` k}$ kappēr ${ }^{c} a l$ ) the congregation. In that way he became a substitute for the sinners and literally carried their wrongdoings in his own body. ${ }^{2}$

When the priest ministered the blood and ate the flesh, he not only took the sin upon him but identified himself so completely with the sinner that the sins he took upon himself became his sins, and he became responsible for them. ${ }^{3}$ (Emphasis his).

\footnotetext{
'Implied in the text which states that "God has given it to you (the priests) to bear the iniquity of the congregation."
}

${ }^{2}$ N. Kiuchi, The Purification offering in the Priestly Literature, JSOT Supplement Series, 56 (Sheffield: Sheffield Academic Press, 1987), 152-3, argues the case that during the "Azazel" ritual Aaron was not simply a representative of the people, but rather a substitute. A similar idea of a prophet's shared guilt as he is identified with a wrongdoer is found in Ezek 14:10. There is no transfer of guilt presented here, but rather the fact that the prophet becomes identified with those to whom he is responsible to impart his message. See also Gerhard F. Hasel, "Studies in Biblical Atonement I: Continual Sacrifice, Defilement//Cleansing and Sanctuary," in The Sanctuary and the Atonement, ed. Arnold V. Wallenkampf and W. Richard Lesher (Washington, DC: Review and Herald Publishing Association, 1981), 103-6.

${ }^{3}$ Milian L. Andreasen, The Sanctuary Service (Washington, DC: Review and Herald Publishing Association, 1947), 138 . 
The nāśā’ Câwôn can thus be seen to express a significant component of the kpr process without necessarily being synonymous with it.'

All of these passages have been directly related to the cultus, or more specifically with the function of the priests. One additional passage, Num $30: 15$, is to a degree indirectly related to the cultus. It is in the context of the sanctity of vows in general. The basic principle expressed is that vows were to be kept (vs. 2), whether they were made by men or women. Both were equally responsible for their vows. If, however, a married woman made a vow and her husband heard about it, he had the option either to confirm it or annul it (vs. 13). In case he decided to annul the vow, it had to be done within a given time, and the Lord would forgive (sālah) the wife (vs. 12). If he waited too long with the annulment he would have to nāsāa her wrongdoing (Cấnāh), not because the vow was wrong, but because the annulment was out of place.

This is the only text in the Pentateuch which explicitly states the possibility of one person nāsa $\bar{a}^{\supset}$-ing the cawwon of another, resulting in the forgiveness of the

\footnotetext{
'For further discussion of their relationship, see Kiuchi, 98-99. He suggests that nāsa cāwôn is a "semantic component" in the "cultic kippēr." This concept is supported, though not explicitly, by similar passages in Lev 5:1, 17; Num $8: 19 ;$ and $18: 22 \mathrm{ff}$.
} 
latter. The concept, however, is not unique. It is found in three other passages in the Pentateuch, twice in Gen 50:17 and once in Exod 10:17. These are all in the form of a request, where a wrongdoer pleads with the wronged to nāśä the wrongs (pešac/hațța ${ }^{\top} \underline{t}$ ) of the wrongdoer so the latter might escape the consequences of his actions. In Gen 50:17 the brothers of Joseph are afraid that he might seek revenge on them upon their father's death. At their father's advice they dispatched a messenger to Joseph to plead with him to nāsā’ their transgression. The first part of the verse records the instructions they gave to the messenger, whereas the latter part tells about its actual delivery.

What the brothers in fact requested was that Joseph "remove" the wrongdoing they had done to him from the sphere of their relationship, so it would no longer pose a threat to their coexistence. Neither the wrong, nor its physical effects could be abrogated. Joseph was in Egypt and had lost about two decades of fellowship with his father and family. That fact could not be changed. The expected natural human response by Joseph was revenge of some kind, which the brothers hoped could somehow be alleviated. In return, they were ready to submit to Joseph's superiority: "We are servants to you" (vs. 18), they submitted. 
Joseph, however, quelled their fears by comforting them, speaking kindly to them and promising to provide for their needs (vs. 21). This response to their request indicates that an integral part of the meaning of nāsás was apparently the concept of caring concern, a concept which was also found in Akkadian texts. ${ }^{2}$

In Exod 10:14-17 Pharaoh was suffering from the eighth plague, that of the locusts. Viewing the total devastation it was bringing upon the land of Egypt, Pharaoh called for Moses and Aaron. Upon their arrival he acknowledged his "sin" against God and them as he pleaded

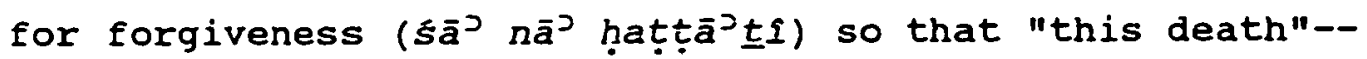
the plaque--might be removed (w'yāsēr) from him. As Moses prayed to the Lord, the Lord responded by employing the wind to nāśa the plaque from the land (vs. 19). The removal (nāsa $\bar{a}^{2}$ ) of the plaque came in resporise to Pharaoh's request to Moses to nāśa his (i.e., Pharaoh's) sin and remove (sar) the plague (vs. 17).

This passage reveals several things about the relationship of nāsa $\bar{a}^{\supset}$ to the wrongdoings of others:

\footnotetext{
'Hebrew uses here a pilpel of the verb $k w l$, the basic meaning of which is to "measure". A derived meaning is "to provide for." In Neh 9:21 it refers to God's general providing care for his people during their wilderness wandering. See also A. Baumann, "ל IJ kwl," TWAT (1984), 4:91-95, an act which in the Pentateuch is referred to as nāśa (see Exod 19:4; Deut $1: 31$; and 32:1012).

${ }^{2}$ See chapter 2 above.
} 
1. Pharaoh acknowledged his wrong and clearly perceived a connection between his sin/wrongdoings and the plague, which he saw as the direct consequence of his "sin."

2. Wrongdoing is concretized; it is considered as a burden which must be carried to its ultimate consequences; it would ultimately bring death to Pharaoh, the wrongdoer.

3. Pharaoh believed the burden of his wrongdoing could be transferred.

4. Pharaoh hoped that he might escape the consequences of his actiors if Moses and Aaron would nāsā’ his wrongdoing.

5. The process of năśa $\bar{a}^{\supset}$ involved a removal (sar) of the consequences.

6. Moses' and Aaron's nāsa $\bar{a}^{\supset}$-ing of Pharaoh's wrongdoing involved making a supplication to God.

7. God is presented as the ultimate remover of the consequences for wrongdoing.

No "payment" or repentance is required from the wrongdoer. The whole process is based entirely on the goodwill of the wronged towards the wrongdoer. The result is that the guilty is freed from the consequences of his actions and the wronged, or a substitute, takes on himself the burden of wrongs. 
The last of the texts in this category, Num 14:33, is somewhat different in that it does not involve any kind of removal or carrying of the wrongs of others on their behalf, but rather it involves a communal sharing of the consaguences of wrong actions.

Num 14 relates the reaction of the people when the spies reported on their investigation of the Promised land.

All the sons of Israel grumbled against Moses and Aaron and the whole congregation said to them, "Would that we had died in the land of Egypt! or would that we had died in this wilderness. And why is the Lord bringing us into this land, to fall by the sword?. - . would it not be better for us to return to Egypt?" (vss. 2,3 ).

When Joshua and Caleb suggested that they follow God's leadership, the whole congregation called for stoning them with stones (vs. 10). By their attitude and ensuing determination to act accordingly, the people, in effect, rejected the whole covenant relationship.' Because of their distrust and rejection of God as their leader, ${ }^{2}$ they would have to bear the consequences of their actions. In spite of the fact that they had been forgiven (vs. 20) ${ }^{3}$ they would not be permitted to enter the Promised Land.

\footnotetext{
'Cf. Deut 31:20 where the expression "spurning [YHWH]" is specifically equated with breaking the covenant.

${ }^{2} \mathrm{Cf}$. 14:4 where the people suggest the appointment of another leader to lead them back to Egypt. below.

${ }^{3}$ For a discussion of God's part in this process, see
} 
Actually, there are five groups of people involved in this incident, each of which is variously affected by the wrongdoing. First, there are the ten spies; second, the remaining two spies, Joshua and Caleb; third, those who were over twenty years of age when they left Egypt; fourth, those under twenty at the time of the Exodus; and finally, the priests and the Levites.'

When it came to the consequences of their action the groups are reduced to three: (1) the ten spies who caused the grumbling, (2) the grumbling crowd, and (3) the "faithful" spies, Joshua and Caleb, together with the descendants of the grumblers and the priests and Levites. By their own free choice the first two groups, in effect, cut themselves off from the covenant and what it stood for. The first to receive the ultimate consequences were the instigators of the grumbling, the ten spies. Shortly after, they died in a plague $(14: 36,37)$. The grumblers did not, right away, feel the impact as severely, but in the end they all lost their inheritance (14:23). The remaining group, through no fault of their own other than being a part of the corporate body of Israel, felt the

\footnotetext{
'This last group is not specified, but its presence may be implied from the total context of the exodus/ eisodus experience. The punishment specified later in the chapter was, however, meant only for those among "the numbered men over twenty" and the Levites were not among those numbered $(2: 33)$. Besides, Eleazar, the son of Aaron, was among those who entered the Promised Land, and apparently died later than Joshua (Josh 24:33).
} 
immediate consequence of the wrongdoing as the fulfillment of the promise was delayed, even though in the end they received the full promise. Their "sharing" in this immediate consequence is here expressed by nāsā’ They would have to remain in the wilderness along with the wrongdoers until the whole transgressing generation had died. The younger generation did not thereby become "coguilty;" neither was the older one released from their guilt. Rather, the younger generation became co-sharers in the consequences, participants in the plight..

\section{Animals as subject \\ In the Pentateuch animals are the subject of nāsa five times.' only one of these is directly and explicitly associated with the process of the sin-removal in the sanctuary ritual. Even though animals were an integral part of the sanctuary services, this usage is a kind of a hapax legomenon in the old Testament. Nowhere else is an animal explicitly associated with this process by the

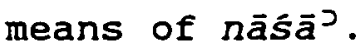

Data

Lev 16:22 And the goat shall bear on itself

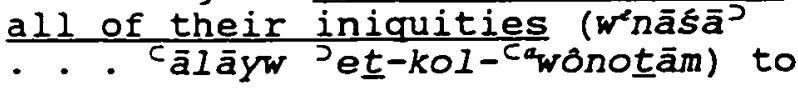

'Gen $37: 25 ; 45: 23(2 x) ;$ Num $23: 24 ;$ and Lev $16: 22$. outside the Pentateuch animals are seen as bearing burdens in $1 \mathrm{Kgs} 10: 2$ and 2 Chr 9:1, or taking other animals for food in 1 sam 17:34. 
a solitary land; and he shall release the goat in the wilderness.

\section{Comments}

Through the centuries the whole pericope involving the two goats on the Day of Atonement has puzzled scholars and theologians alike. The problem is primarily related to the meaning and function of the "goat for Azazel."1 J. A. Gladson cogently dealt with these issues in a thesis a couple of decades ago." Having brought together "a menagerie of conflicting data and opinion" ${ }^{3}$ through the centuries, he summarizes the possible meanings of Azazel under three main headings:

1. Azazel means "entire removal"t; the word being a reduplication of the stem ${ }^{2} z 1$ "to go."

2. Azazel is the name of the place where the goat was cast to its death, according to post-Biblical tradition and ritual.

\footnotetext{
'For a recent discussion of the issue and extensive bibliography on the subject of Azazel, see David P. Wright, The Disposal of Impurity, SBL Dissertation series, 101 (Atlanta: Scholars Press, 1987), 21-30. See also Hayim Tawil, "Azazel, The Prince of the Steepe: A comparative Study." ZAW 92/1 (1980), 43-59.

'Jerry A. Gladson, "The Enigma of 'Azazel' in Leviticus 16" (M.A. thesis, Vanderbilt University, 1973).

${ }^{3}$ Ibid. , 124 .

'So for instance, BDB, 736 .
} 
3. Azazel is descriptive of a demonic personal

being. Paul Heinisch summarizes that position quite well

when he says:

But since Azazel was given a goat he must have been regarded as a personal being; and since the sins of the people were consigned to him, a demon. He stands opposed to Yahweh as Satan does in Job 1 and 2 and the serpent in Gen 3. Because the people thought that demons dwelt in desert places, the scapegoat was driven out into the wilderness.'

Some scholars, among them Freedman and Willoughby, ${ }^{2}$ see still another option. The two goats are really just two aspects of the forgiveness process, one representing the sacrificial death necessary as a precondition to forgiveness, the other the "carrying" aspect, whereby God carries and removes the sins from the camp, and thus forgives them.

Admittedly, the significance of Azazel remains an enigma in Biblical scholarship. Perhaps Wenham has evaluated the whole problem accurately when he says,

Whatever we understand by Azazel, there is little doubt about the total meaning of the ceremony. . . it all comes back to the same basic idea: that sin is exterminated from Israel. ${ }^{3}$

\footnotetext{
'Paul Heinisch, Theology of the old Testament, trans. William Heidt (Collegeville, MN: Liturgical Press, $1950), 137$.

${ }^{2}$ See Freedman and Willoughby, 637.

${ }^{3}$ Gordon J. Wenham, The Book of Leviticus, NICOT

(Grand Rapids: Wm. B. Eerdmans Publishing Company, 1979), 235 .
} 
Another question which arises in this context is: "Which sins are dealt with in this ritual on the Day of Atonement?" Is it the sinners' unconfessed sins,' the brazen wanton sins of the high-handed sinner, ${ }^{2}$ or the totality of the sins of the children of Israel which throughout the year had contaminated the sanctuary and the sancta? ${ }^{3}$ Rodriguez argues correctly that the most straightforward reading of the text indicates the last suggestion as the most natural. As the last act of the special Day of Atonement ritual, the High Priest--having made an atonement for the various objects of the sanctuary --placed his hands on the head of the Azazel goat.s

'So Andreasen, 205-07, who sees Azazel representing the devil who will have to bear the sins for which he is ultimately responsible along with the unconfessed sins of the people.

${ }^{2}$ So Jacob Milgrom, Leviticus 1-16, AB (New York: Doubleday, 1991), 1040 .

${ }^{3}$ Ibid. , 117 .

tSee ibid., 114-20, for further discussion of this issue.

${ }^{5}$ Kiuchi, 149-53, has pointed out that usually the preposition $C_{a l}$ and the third masculine singular pronominal suffixes in connection with the Azazel goat in vss. 10 and $21-22$ have been seen as referring to the goat, indicating expiation in 'proximity to' (Levine), expiation 'for' (Keil), atonement 'over' (traditional Jewish

scholars and some modern scholars) the Azazel goat; or it might be a scribal error. Kiuchi suggests rather that these be read as referring to the Azazel goat atoning for Aaron in analogy with other usages of this expression in the same chapter. Aaron is not simply envisaged as the representative of the people. He has taken upon himself the guilt of the people and the sancta and thus becomes 
Thereby he transferred the sins of the people, which had been "accumulated" in the sanctuary throughout the year, and for which they had already received forgiveness during the year, to the head of the goat which was then led out into the wilderness, removing the sins of the people from the camp, thus eliminating them as far as they were concerned.

\section{In spite of various problems related to the}

identity and function of the goat for Azazel, it is clear from this passage that (1) forgiveness is nowhere mentioned in connection with the Day of Atonement ritual; (2) the goat for Azazel was not killed, neither was its death a part of the sanctuary symbolism, and (3) the goat was not presented as an offering sacrificed to Azazel. Actually, it is never designated as a sacrifice; neither was it a gift or an appeasement, nor a substitute sent to Azazel to suffer in Israel's place.' It did not serve as

guilty in a substitutionary capacity. Now he lays his hands on the head of the Azazel goat, placing his guilt on it, which the latter then carries off into the wilderness.

'The implication that the goat may have wasted away in the wilderness is not the issue here (cf. Whybray, 49 and note 74). Wright points out that wilderness is not necessarily a wasteland. Rather it is arid land with little vegetation except grass for pasturage of various wild animals. Most important about the wilderness is the fact that it is not inhabited by humans (p. 29). The explicit emphasis is, therefore, not on the destruction of this goat but rather on the ultimate removal/elimination of ali wrongdoings of the people away from the camp. This idea of removal seems to be strongly emphasized by the fact that besides the preposition cal, indicating the 
an active participant in the atonement process, but rather it served only as a vehicle of transport (nāśa $\vec{a}^{2}$ ) for the sins of Israel, which separated them from God, to remove them from the populated areas to a place where they could not threaten human populations.' Through this process the people were again brought into relationship with their God.

\section{Divine Deings as Subject}

In this category there are four passages. Two of them are in the form of liturgical declarations, or possibly confessions of faith about the character of YHWH (1), one is an intercessory plea (2) and one is in the form of a warning (3).

Data

1. Confessions of faith

Exod $34: 6,7$ The Lord, the Lord God, compassionate and gracious, slow to anger, and abounding in loving-kindness

carrying aspect, both the directional -āh and the preposition $e l$ are used to indicate the movement.

'See D. Wright, 29-30, and Rodriguez, chap. 3. See also Freedman and Willoughby, "nāśä", TWAT (1986), 5:637, and Whybray, 49. Whybray adds correctly that "the ritual of the scapegoat reflects a concept of $\sin$ as something menacingly close to the sinner which terrifies or threatens to destroy him by weighing upon him, a state which can only be relieved by its being taken away and removed to a distance."

${ }^{2}$ So for instance Robert $c$. Dentan, "The Literary Affinities of Exodus XXXIV 6f", VT 13 (1963):37. 
Num $14: 18$

and truth; who keeps lovingkindness

for thousands, who forgives

iniquity, transqression and sin

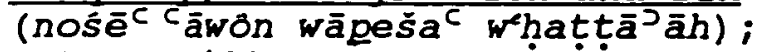

yet He will by no means leave the

guilty unpunished, visiting the

iniquity of fathers on the children

and on the grandchildren to the

third and fourth generation.

The Lord is slow to anger and

abundant in lovingkindness, forqiving iniquity and trans-

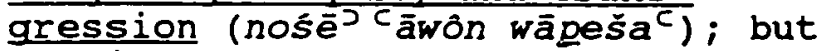

He will by no means clear the

guilty, visiting the iniquity of

the fathers on the children to the

third and the fourth generations.

2. Intercessory plea

Exod $32: 31,32$ Alas, this people has committed a great sin, and tiney have made a god of gold for themselves. But now, if Thou wilt, forgive their sin

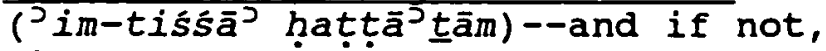
please blot me out from Thy book which Thou hast written.

3. A warning

Exod 23:21

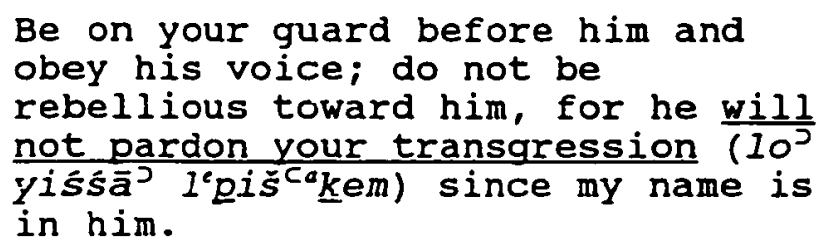

Comments

Dentan states about the passage in Exod $34: 6,7$

that it is so remarkable, that the majority of modern commentators take it to be a "foreign intrusion into the present text" entered in a late editorial stage.' Others,

I'Ibid., 36. 
like Moberley, see it rather as an original "part of the narrative tradition in which. . . [it] now stand[s]" from which other liturgical confessions were derived.'

[It] stands out from the theological formularies of the OT by its "propositional" nature. It is not kerygmatic but descriptive; it is concerned not with God's acts, but with His character.'

This passage is a part of the so-called "sinaitic theophany" which is used in various contexts throughout the OT. ${ }^{3}$ It is one of the high points of Biblical revelation, and it comes in response to Moses' request of God in Exod 33:19, "Show me thy glory." In response, God does not reveal himself in anthropological terms but rather in personal, relational terms. As a part of this revelation God not only shows himself compassionate (raḥum) and gracious (ḥannûn), slow to anger (Jerek Jappay $1 \mathrm{~m}$ ) and abounding in lovingkindness and truth (rabhesed we $^{\mathrm{e}}$ emet), but also as one who maintains and protects that covenant-loyalty or lovingkindness for thousands

'R. W. L. Moberly: At the Mountain of God, JSOT Supplement Series 22 (Sheffield: Sheffield University Press, 1983), 128-31. The statement is clearly explicitly reflected in eight passages in the old Testament: Num $14: 18$; Neh $9: 17$; Pss $86: 15 ; 103: 8 ; 145: 8$; Joel 2:13; Jonah $4: 2 ;$ and Nah $1: 3$.

${ }^{2}$ Dentan, 48 .

${ }^{3} \mathrm{An}$ excellent discussion and bibliography is found in Dawn E. Waring, "The Nature of Yahweh's Relationship with His People: A Literary Analysis of Exodus 32-34" (Ph.D. dissertation, Fuller Theological Seminary, 1985), 169-88, and David N. Freedman, "God, Compassionate and Gracious," Western Watch 6 (1955):6-24. 
(noṣēr hesed $1 \bar{a}^{\partial a} 1 \bar{a} \underline{i} \hat{i} m$ ) and a bearer of every kind of sin (nośēe ${ }^{c}$ āwôn wāpeša ${ }^{c}$ whaṭțāāh), ' without, however, declaring the guilty guiltless (w'naqgēh $10^{2}$ ynaqqēh), one who visits the iniquity (poqẹ ca cân) of the fathers on the children and grandchildren to the third and the fourth generations. ${ }^{2}$

\section{Many theologians consider this passage as a} liturgical confession. ${ }^{3}$ Wright points out that this is the only confession in the oT composed solely of the divine attributes." The text, however, claims that these words are actually God's self-appraisal "in order to clarify and explain his role in the tragic incident of the golden calf." In the process of Moses' intercession for

\footnotetext{
'The fact that the three OT key-words for sin/ wrongdoing are listed as objects of năs $\bar{a}^{\supset}$ does not necessarily imply that only these different aspects are included to the exclusion of others, but they are rather used to indicate the universality of wrongdoings involved, (i.e., all sins). See Knierim, 233; also Pedersen, 1:414; and K. H. J. Fahlgren, quoted Knierim, 234, note 28 .

${ }^{2}$ These characteristics of God are ably discussed by Freedman, "God, Passionate and Gracious," 6-24, and G. Ernest Wright, "Divine Name and Divine Nature (Exod 33:1234:9)," Perspective 12 (1971):177-85.

${ }^{3}$ Among them Gerhard von Rad, The Problem of the Hexateuch and Other Essays (trans. E. W. Trueman Dicken from a 1958 reprint of the original German edition of 1938 ; London: 1966), 1-78; G. E. Wright, God Who Acts: Biblical Theology as Recital (London: SCM Press, 1952) chapter 2, and Dentan, 36, notes 2-9.

'G. E. Wright, "Divine Name," 177.

${ }^{5}$ Freedman, "God, Compassionate and Gracious," 7.
} 
the people, God proposes to blot out the people and begin anew with Moses,' but Moses insists that such an action would be irreconcilable with God's character. ${ }^{2}$ Instead, Moses pleads with God to bear/forgive their sin ( ${ }^{\prime}$ im tiśs̄ā haṭtă Moses recognizes, and God confirms, the inevitable association between cause and effect which is the resounding undercurrent throughout the OT: the one who sins will bear his iniquity with all it engenders, including both immediate and ultimate consequences." But, within God's justice there is also room for mercy. God has not forsaken his people. He will remain with them through his angel.s

This theophany can be divided into two main parts, with the first consisting of two universal declarations about the character of God:

1. Jèl raḥum whananun. "God, compassionate and gracious."

'Exod 32:10

${ }^{2}$ Exod $32: 11-13$.

${ }^{3}$ Exod $32: 32$.

${ }^{4} \mathrm{C} f$. the summary statement in Ezek 18:4, 20 "The soul that sins will die." See also G. E. Wright, "Divine Name," 181, where he points out that "to ancient Israel the Law of God cannot be broken or disregarded without someone bearing the burden of sin, that is, the penalty. Law cannot be broken with impunity."

${ }^{5}$ Exod $32: 34$. 
2. Jerek Jappayím. "slow to anger and abounding in lovingkindness and truth."

The second part consists of three action-oriented statements, indicating how the general characteristics of God are translated into actions at the point of contact between God and man. All of these statements begin with a participle indicating "a continual uninterrupted exercise of an activity."' God's acts are not at random, sporadic; they are predictable, reliable and permanent, in contrast to those of man.

1. noṣēr hesed $1 \bar{a}^{\supset a} 1 a ̄ p i m$. "One who keeps/maintains covenant-love for thousands."

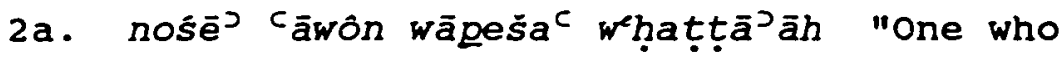
forg:ves/carries iniquity, transgression and sin. . . "

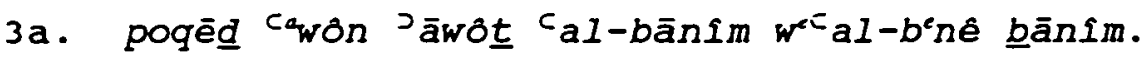
"One who visits the iniquity of the fathers upon children and descendants."

on the surface there appears to be a contradiction between the last two general statements. One proclaims forgiveness, the other punishments, not only for the wrongdoers but also on the descendants. Both of them, however, are qualified by balancing statements:

2b. W'naqqēh $10^{2}$ y'naqqēh ". . . but he will certainly not declare guiltless (or: leave unpunished)."

'Gesenius, \$116:a. 
3b. Cal-šillēśim wal-ribbēcim ". . . to the third

and fourth generation."

These statements indicate that there are limits

both to God's mercy and his punishing. Being merciful and forgiving is not the same as letting the guilty go free or declaring them innocent, nor is punishing without limits. Whereas God's mercy is for the benefit of thousands, the consequences of wrong actions are, however, limited to a few generations.

The expression nose $\bar{e}^{\supset}$ Cawón is crucial to the present study. It means literally "one who carries/ removes wickedness." God is thus presented as one who continually bears the wickedness of his people.' Rather than destroying the people who had acted wrongly, God takes upon himself their wrongdoing, thereby subjecting himself to the consequences.2 The people, on the other hand, would continue to live and benefit from his guidance

\footnotetext{
'Note the use of the participle, which "tends to describe a state of affairs rather than to present a bare event" or "a continuing state of affairs." Bruce $k$. Waltke and $M$. O'Connor, An Introduction to Biblical Hebrew Syntax (Winona Lake, IN: Eisenbrauns, 1990), 614, 626 .

${ }^{2}$ Compare with the concept of the suffering servant in Isa 52:13-53:12. Cf. Freedman, "God, Passionate and Gracious," 15-16. G. E. Wright, "Divine Name," 182, adds that God did this to maintain the covenant with Israel. "Such an expression, with the Biblical world behind it, has so much more depth of meaning than the simple English abstraction "to forgive" with its range of meanings."
} 
and protection.' But this "forgiveness" by God does not mean that the people would be declared guiltless (w'naqgēh $10^{2}$ yenaqgēh) nor that they would totally escape the consequences of their actions.' So, nāsāj-forgiveness does not necessarily exclude punishment/consequences, nor does it mean a declaration of innocence, but it does involve participation and support by the forgiver in the suffering of the wrongdoer.

Also, nās $\bar{a}^{\supset}$-forgiveness does not appear to involve forgetting in the regular sense of the word. This is brought out in the pericope about the spies, as they returned from exploring the Promised land in Num 14. The people refused to believe the faithful spies and rebelled against God's leadership and Moses.' God proposed to Moses to dispossess the people and he would exalt Moses instead and make him into a great nation." Moses interceded for his people and appealed to the theophany in

\footnotetext{
${ }^{1} A s$ is revealed in Exod $32: 34$ where God promises to send his angel to lead the people. He also promises to fight the battles for them $(34: 10$, il).

${ }^{2}$ The people and their children still had to remain in the wilderness, and only two of the original group of those who were over twenty years of age when they ieft Egypt were allowed to enter the Promised Land (cf. comments on Num $14: 18$ ).

${ }^{3}$ Num 13-14.

sum $14: 12$.
} 
Exodus in a somewhat abbreviated form.' ${ }^{1}$ on the basis of that revelation of God's nature Moses pleaded with God to forgive (sälah) the iniquity of the people, just as he had forgiven/carried (nāsīa $\bar{a}^{J}$ ) them from Egypt onward.

God responds by assuring Moses that he had already forgiven (sālah qal perf.) them according to Moses' request, but this forgiveness did not imply the removal of the consequences of the wrong action.

Das Konkretwerden der Vergebung wird nicht im Aufheben der einzelnen Strafen gesehen, sondern primär in der Erhaltung der Beziehung $z$ wischen JHVH und seinem Volk. ${ }^{2}$

God made an oath in which he proclaims that even though he has forgiven the people, they will have to bear the consequences of their rebellious actions. Following the people's rejection of Joshua and Caleb's spy-report, God appeared "exasperated" as he spoke to Moses. "How

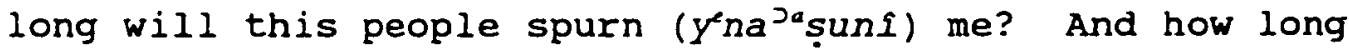
will they not believe in me?" (vs. 11). Sakenfeld points out that all fourteen OT occurrences of $n \bar{a}^{3}$ aș in Piel

'He omits (1) the doubling of the name YHWH, (2) the title God, (3) the introductory statement "compassionate and gracious," (4) the expression "and truth," (5) the qualifying statement "who keeps lovingkindness for thousands," (6) the expression "and sin," and (7) the extended family "and on the grandchildren." None of these omissions appears to have any real theological significance in this context, however.

${ }^{2} \mathrm{~J}$. Hausmann, "П D sālah", TWAT (1986), 5:865. See also Katherine D. Sakenfeld, "The Problem of Divine Forgiveness in Numbers 14," CBQ 37 (1975):327. 
refer without exception to the despising or spurning of God or something sacred to him. The contexts suggest that the action is regarded as tantamount to rejection of the whole covenant relationship.'

That kind of an attitude will inevitably bring its consequences. When God pronounced the judgment on the people he was not arbitrarily unleashing his temper, but rather expressing the unavoidable results of their decision: disinheritance and pestilence (i.e., exclusion from God's protective covenant blessings).2

As Moses interceded, he did so, not on the basis that injustice was being done or that God was arbitrary in his decisions, but rather on the basis of God's nature, especially his hesed (vs. 13) which sakenfeld has shown is used of God in the context of preserving a relationship which he has already created. ${ }^{3}$ The pericope does not indicate any forgettingt or removal of the consequences as

'Sakenfeld, 321. This is especially apparent in Deut 31:20 where despising of Yahweh is equated with the breaking of the covenant.

${ }^{2}$ Cf. Exod 15:26 and Deut 29:20.

${ }^{3}$ Sakenfeld, 324 , note 16 .

${ }^{4}$ In fact, the idea of forgetting is nowhere expressed or implied in the context of forgiving in the Pentateuch. In Jer 31:34 "forgive" is chiastically in parallel with "remember no more," which is clearly, at least partially, synonymous with forgive (see: Herrmann Eising, "7J zäkar", TDOT, 4:65). That idea poses serious theological problems as to "How can God forget?" It may be helpful to note that the text does not actually say "forget," but rather "not remember." This may seem an insignificant difference, but whereas God's remembering always results in actions (Eising, 66), God's "nonremembering" may be seen as referring to God's "non- 
being inherent in the concept of forgiveness. It appears to be more a relational process in which the forgiver removes or bypasses the obstacle which obstructs the relationship with the one forgiven, thus restoring/ maintaining the relationship.

Sakenfeld is correct in her analysis of forgiveness in this context, that

[it] has to do with the preservation of the fundamental covenant relationship rather than simply with eliminating some particular act of punishment (e.g, Jer $5: 1,7 ; 31: 34 ; 50: 20)$. . . . Forgiveness is understood basically as preservation of the community, and this preservation need not be precluded or even cheapened by punishment of the community while the relationship is being continued.'

As can be seen in table 21, the last text in this category, Exod 23:21, issues a warning to the people of Israel during their wandering in the wilderness as to the danger of rebelling against God's angel whom he promised to send before them to guard them on their way. Von Rad has pointed out that the expression mal'āk yhwh is "the personification of Yahweh's assistance to Israel" and obviously even God himself in human form. ${ }^{2}$ Therefore, he

action" in bringing on the logical consequences of a given wrongdoing. For the sinner it has the same effect as if he had not sinned. (See also: Willy Schottroff, "Il zākar gedenken", THAT, 1:507-18.)

'Sakenfeld, 327.

${ }^{2}$ Gerhard von Rad, "7K'D in the OT," TDNT (1964), 1:77-78, and idem, Genesis, trans. J. H. Marks (Philadelphia: Westminster Press, 1961), 188-9. 
is to be obeyed, trusted and respected. Rebellion against him is rebellion against God himself and will not be toierated nor forgiven ( $\left.n \bar{a} \bar{s} \bar{a}^{2}\right)$.

The question arises, however, "Why will he not forgive?" since God had already established himself as a forgiver of the people and their wrongs.' This is, in fact, the only passage in the Pentateuch in which the nāsā’ of wrongdoings is negated. There is one parallel passage involving sālaḥ in Deut 29:20 (19 MT) speaking of someone who has turned away from God to serve other gods (cf. vs. 18)

The Lord shall never be willing to forgive (selah) him, but rather the anger of the Lord and His jealousy will burn against that man, and every curse which is written in this book will rest on him, and the Lord will blot out his name under heaven.

Besides these two passages in the Pentateuch there are eight outside that corpus with a similar message, five with nāsājo and three with sālaḥ. ${ }^{3}$ Both the Pentateuchal passages and six of those outside involve God as the subject. The cause for the negative reaction is a rebellious attitude leading to the worship of foreign

'Cf. Exod $34: 6,7$; and Num $14: 18$.

${ }^{2}$ Jos $24: 19$; Isa $2: 9$; Ezek $34: 29 ; 36: 15$; and Job $7: 21$

${ }^{3} 2$ Kgs $24: 4 ;$ Jer $5: 7 ;$ and Lam $3: 42$. 
TABLE 21

Nāsā̃ WRONGS OF OTHERS

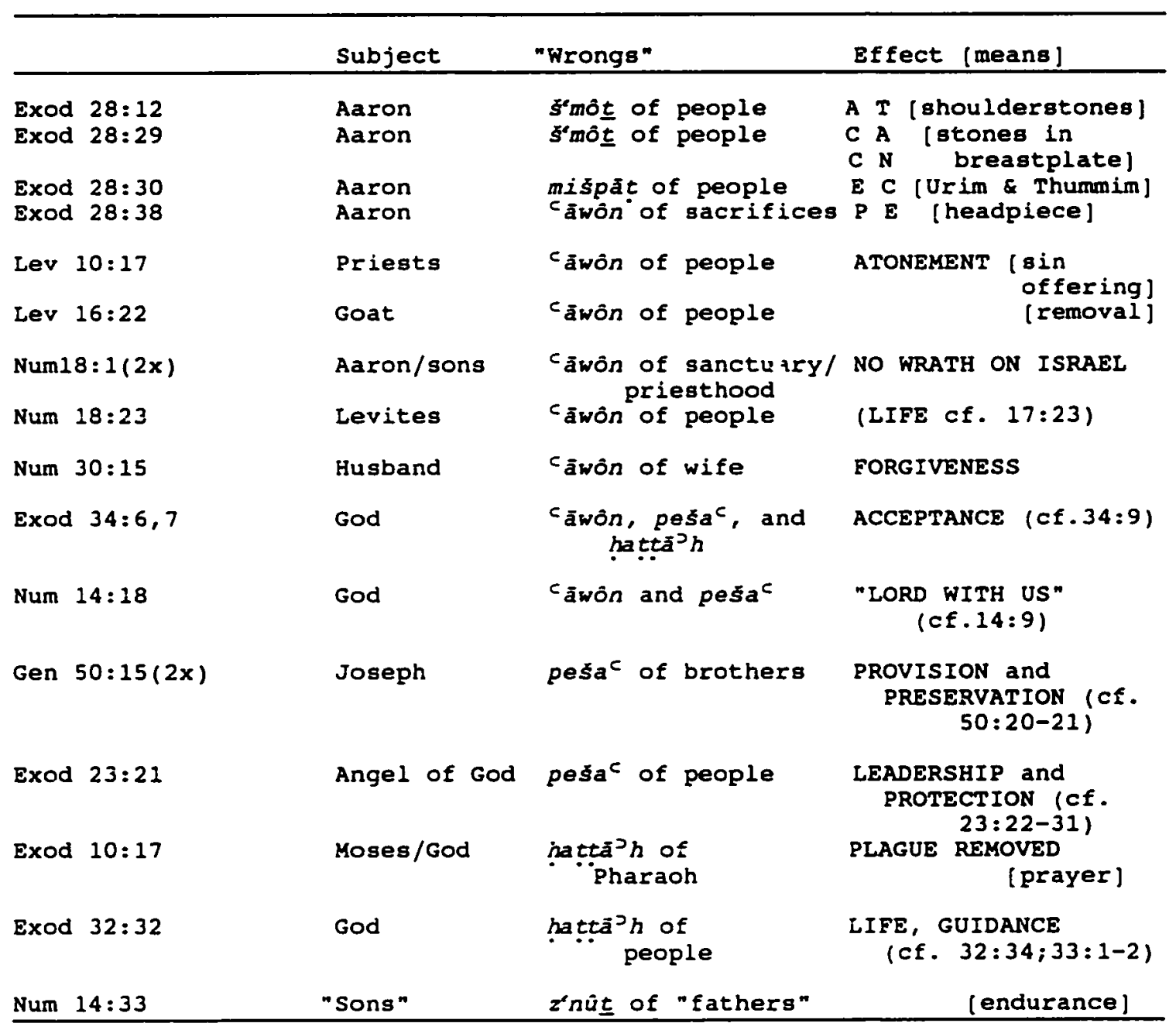


gods,' turning away from the Lord to serve the gods of heathen nations," the worship of the "work of their hands," 3 the fact that "your sons have forsaken Me and sworn by those who are not gods, "general rebellion," or indescribable atrocities against innocent people. ${ }^{6}$ In one passage Job challenges God to explain why He has not forgiven him, ${ }^{7}$ and two passages in Ezekiel are more general in nature: that one nation will no longer bear the insults or reproach of other nations.

All these texts, with the possible exception of the last two, speak of grievous and rebellious attitudes, even involving rejection of God as the leader and God of the people. The people have turned to others instead. That is why God cannot bear (nās $\bar{a}^{2}$ ) their wrongdoings. They do not want him to. This is apparentiy the only context in which forgiveness is negated in the OT.' God

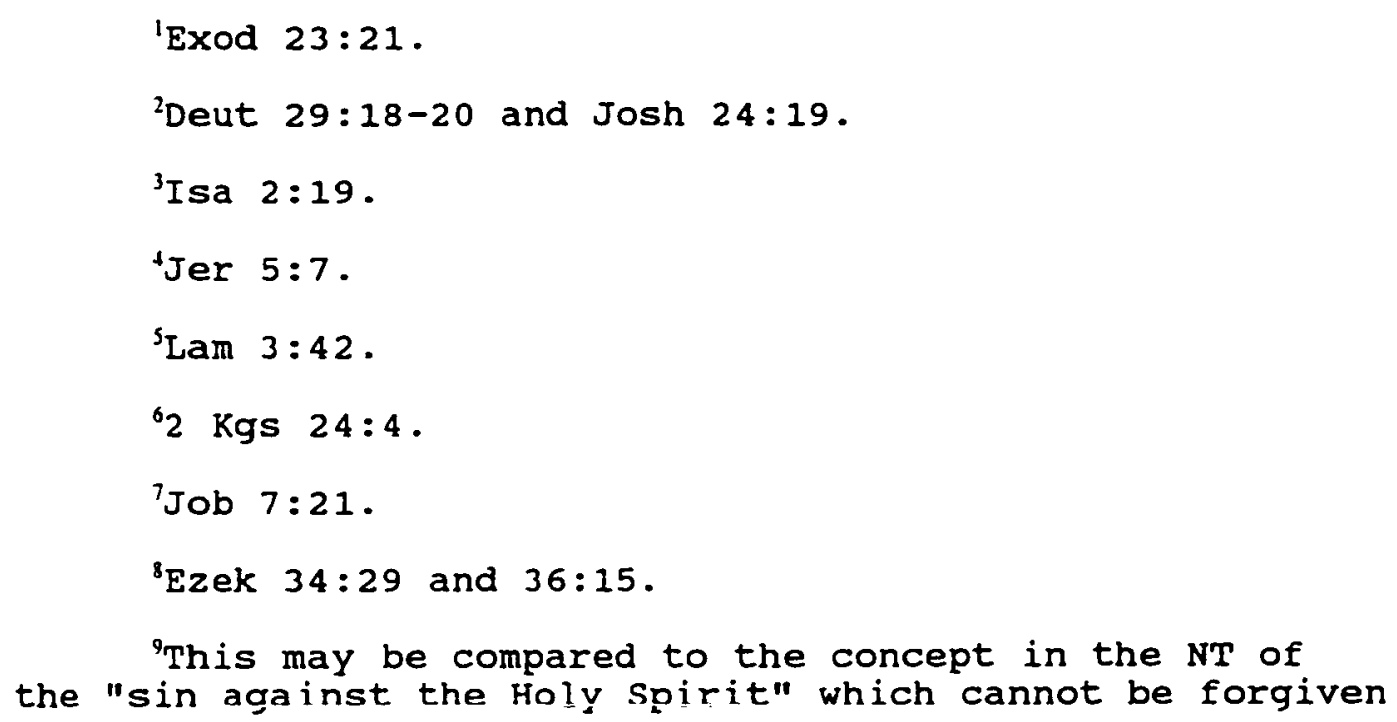


cannot carry the wrongs of those who will not accept it, and he will not force their will. They have to bear the consequences of their actions themselves.

When someone carries the wrongs of others the consequences for the "carrier" are not explicitly stated. It becomes clear from the context, however, that the beneficiaries of that action are always relieved of their burden, whether that meant the responsibility for their actions, punishment, or death. The effect on the one who takes their "burden" can, however, be safely assumed in light of what happened to those that bore their own iniquities: suffering, disease, and/or death (see table 20).

\section{Summary}

Man, a designated animal, or God himself may be the subject of nāsā’ when the sins/wrongdoings of others are involved. The basic principle involved is that whoever does not live in accordance with a given standard becomes guilty and must bear (nāśā' whether that be guilt-feeling or some kind of punishment. Ultimately, the wrongdoer who bears his wrongdoings will suffer and even die.

(Matt 12:31-32 and Mark 3:28-29). There the context also indicates an attitude of rejection of God and what he stands for. 
But because of his caring concern for his people God has provided a way out. In the sanctuary the priests and Levites were appointed to bear (nās $\bar{a}^{2}$ ) the wrongdoings of the people within the confines of the sanctuary, thus releasing the people from the consequences of separation and death.' The priests sometimes ate of the flesh of the sin-bearing sacrifice, thereby making it a part of themselves, 2 or signified their substitutionary function visually by means of the stones which the highpriest carried $\left(n \bar{a} \bar{s}^{j}\right)$ as part of his vestments, together with the inscribed golden plate on his forehead. Thus they

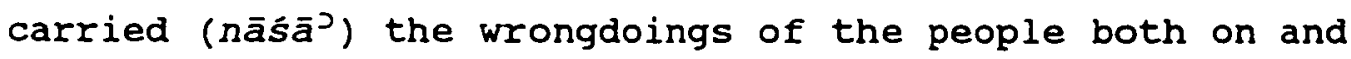
in their body as they entered into the presence of the Lord. This process provided the people with an acceptance before the Lord. ${ }^{3}$

Once a year, as a part of the Day of Atonement ritual, the "goat for Azazel" was set apart for the purpose of transporting (nās̄ẩ sins of the people from the sanctuary, away from the camp, out into the wilderness. This act of elimination culminated and sealed the forgiveness process which the people had already been experiencing through their

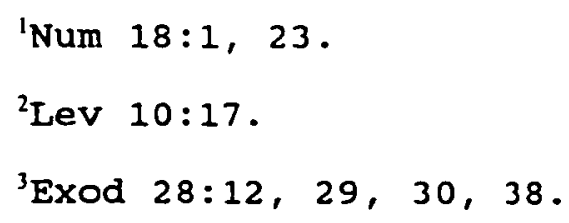


involvement in the daily rituals of the sanctuary through their substitute.

A husband could take on himself (nāsāj) the responsibility/consequences for a vow made by a "dependant" of the household,' thereby releasing that individual from his/her duty and providing forgiveness for that person. ${ }^{2}$ In the same way the wronged could also take on himself (nāśa $\bar{a}^{2}$ ) the wrongs of another, effectually remove it from their relationship, and ultimately also take care of the wrongdoer and provide for his needs. ${ }^{3}$

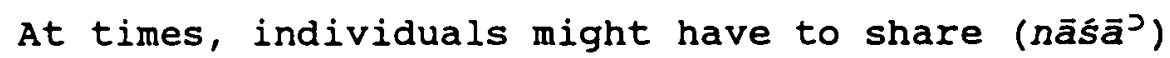
in the immediate consequences of someone else's wrongs through no fault of their own, without being counted guilty or releasing the wrongdoers from their guilt." But they could also be instrumental in the removal of the consequences of someone's wrongdoings by taking ( $n \bar{a} s \bar{a}^{2}$ ) them in prayer to God, the ultimate bearer (nosiej) of wrongs, who also provides the ultimate release from the consequences. ${ }^{5}$

\footnotetext{
'Only the wife is specified in the text, but it seems probable that other dependent individuals were implicitly included in this provision (cf. Num 30:3-5).

${ }^{2}$ Num $30: 15,12$.

${ }^{3}$ Gen 50:17.

'Num 14:33.

${ }^{5}$ Exod 10:17.
} 


\section{$N S^{\supset}$ AND INTERPERSONAL RELATIONS}

There are a total of twenty-two passages in the Pentateuch in which nāsa $\bar{a}^{2}$ is used in the context of an attitude or particular relationship towards someone. This concept is found in such expressions as nāsa $\bar{a}^{\supset}+$ person/

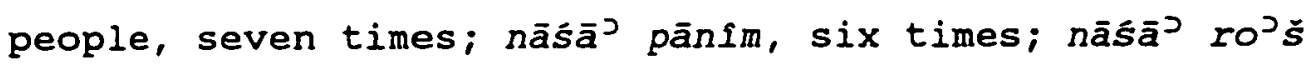

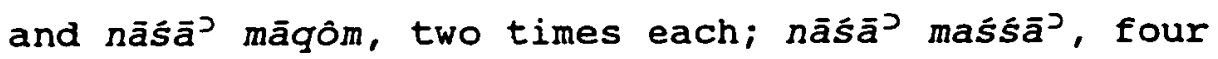
times; and nāsa ${ }^{\prime}$ without an object, once. The subject may be either man or God.

In this group of texts we find positional indications with the verb in nine cases: cal is used three times: twice indicating a caring action, ${ }^{2}$ and once it is not used directly with the verb but in the context to indicate a movement from disgrace to honor. ${ }^{3}$ Min is used twice: once about literally separating the head from the

'These do not directly indicate relationship or attitude, but are semanticaliy very closely related to the expressions with people as objects and are, therefore, included here.

${ }^{2}$ Num 11:12; Deut 32:11.

${ }^{3}$ Gen $40: 13$. 
body,' once about Egypt as a point of departure. ${ }^{2}{ }^{2} E I$ is used about the direction towards which God will show his favor, ${ }^{3}$ and $I^{e}$ appears also to indicate the direction of favor in three passages."

Again, it appears difficult to distinguish clearly between movement and sustaining, but all but one of the passages with prepositions seem to indicate some kind of movement or attitude towards someone. The passage in Deut 32:11 with cal seems to emphasize the caring acts of the mother-eagle towards her young. Most of the remaining passages, which have no preposition, seem to imply an attitude of sustaining and favor.

\section{People as object}

All of the occurrences in this category are in the context of the people of Israel passing through the wilderness at the time of the Exodus. Four have God as subject (1), three of which are in the form of $\bar{a}$ confession or declaration, ${ }^{5}$ one an intercessory prayer $i^{6}$ and seven have Moses or his assistants as subject (2),

${ }^{1}$ Gen $40: 19$.

${ }^{2}$ Num $14: 19$.

${ }^{3} \mathrm{Num} 6: 24,25$.

'Deut 28:50; Gen 18:24,26. Cf. Waltke, 206.

${ }^{5}$ Exod 19:4; Deut $32: 11$; and $1: 31$.

oNum $14: 19$. 
with four forming a part of Moses' complaint to God about the awesome responsibility of leading the people, ${ }^{1}$ and the remaining three constituting God's response to these complaints. ${ }^{2}$ Two of these passages present some generalizations with man as subject, used for comparison. ${ }^{3}$

Data

1. Subject: God

Confession/declaration

Exod 19:4 You yourselves have seen what I did to the Egyptians, and how I bore

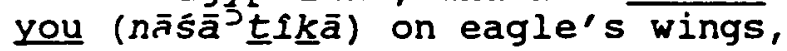
and brought you to Myself.

Deut 32:11 Like an eagle that stirs up its nest, that hovers over its young, He spread His wings and caught them, He carried them (yiśs̄̄o èha) on His pinions.

Deut $1: 31$

And in the wilderness where you saw how the Lord your God carried you ( $\left.n^{e} \bar{s}^{2}{ }^{J a} k \bar{a}\right)$ just as a man carries ( $y i s \bar{a}^{3}$ ) his son, in all the way which you have walked, until you came to this place.

Intercession

Num $14: 19$

Pardon, I pray (selah-na') the iniquity of this people according to the greatness of Thy lovingkindness, . . just as thou

'Num 11:12, 14; and Deut 1:9, 12 .

${ }^{2}$ Exod 18:22; and Num 11:17 (2x).

${ }^{3}$ Deut 1:31; and Num 11:12. 


\section{hast forgiven (nāsā’tāh) this} people from Egypt until now.

2. Subject: Moses and his assistants

Moses' complaint

Num 11:12

$$
\begin{aligned}
& \text { Was it I who conceived this people? } \\
& \text { Was it I who brought them forth, } \\
& \text { that Thou shouldest say to me, } \\
& \text { Carry them ( } s \bar{a}^{2} \bar{e} h a \text { ) in your bosom }
\end{aligned}
$$

Num 11:14

Deut 1:9

Deut 1:12

And I spoke to you at that time, saying, I am not able to bear ( $\left.\bar{s}^{e} \bar{e} \underline{t}\right)$ the burden of you alone.

How can I alone bear ( ${ }^{2} s \xi \bar{a}^{2}$ ) the load and burden of you and your

God's response

Exod 18:22

Num 11:17

$$
\begin{aligned}
& \text { And let them judge the people at } \\
& \text { all times; . . . So it will be } \\
& \text { easier for you, and they will bear } \\
& \text { the burden with you (wnás } \\
& \text { Jitták). }
\end{aligned}
$$

And they shall bear the burden of the people with you (wrnās $\bar{s}^{\top} a^{2} i t t^{\prime k} \bar{a}$ bemaśsa's), so that you shall not bear $\left(w^{2} I O^{2}-t i s s^{2} \bar{a}^{2}\right)$ it alone.

Comments

In the first of these passages, Exod 19:4, God is speaking to Moses in preparation for the giving of the covenant on Mount Sinai. This passage forms, in fact, an introduction to the giving of the covenant. In it God 
compares the initial experience of Israel in the wilderness to that of their being carried on eagle's wings,' with God being the carrier. Kleinig ${ }^{2}$ points out that this is the only text in which God speaks of bringing the people to himself. At other times he brings them to the land. This emphasis on God's care for his people, as the covenant is introduced, is significant, as it shows that it is based on a relationship of love. It also indicates the close interrelationship between the concepts of nās $\bar{a}^{2}$-forgiveness and the covenant. The same simile is used again in Deut 32:11 as Moses reviews Israel's experience during the forty-year wandering in the sinai desert. In this latter passage the simile is expanded by graphically describing the way eagles teach their young to fly, a scene readily visible to the people in the desert, especially in spring as they arrived at Mount sinai. It has, however, been quite difficult to verify this behavior

\footnotetext{
'Some scholars believe that the Hebrew nešer is not the eagle but rather the Griffon vulture which is abundant in these regions. See Samuel R. Driver, ICC, 162 ; Encyclopedia Judaica, 16:232-3, and Godfrey R. Driver, "Birds in the Old Testament" PEO, 86 (1955): 8-9. The last one, however, indicates that it may be used for either the vulture or the eagle. In a later article, idem, "Once Again: Birds in the Bible", PEQ, 90 (1958): 56-57 he admits that he had wrongly ascribed Exod 19:4 and Deut $32: 11$ to the vulture "because of the great span of its wings."

'John w. Kleinig, "On Eagles' wing. An Exegetical Study of Exodus 19:2-8," Lutheran Theological Journal 21/1 $(1987): 20$.
} 
of the eagle scientifically,' but the following description may be helpful in illuminating this unique event which is being used as a picture of God's nāsā’-care for his people.

The mother started from the nest in the crags and, roughly handiing the youngster, she allowed him to drop, I should say, about ninety feet; then she kould swoop down under him, wings spread, and he would alight on her back. She would soar to the top of the range with him and repeat the process. Once perhaps she waited fifteen minutes between flights. I should say the farthest she let him fall was a hundred and fifty feet. My father and I watched him, spellbound, for over an hour. ${ }^{2}$

The eagle is also frequently used as a symbol of royalty in Ancient Near Eastern cultures, ${ }^{3}$ and as such is an apt symbol of God, the almighty Ruler of the universe.

'Some commentaries such as The Pulpit commentary, (Grand Rapids: Wm. B. Eerdmans publishing Company: 1977), 3:500, quote a description from a book first published in 1829 by the name of Salmonia: Or Days of Fly Fishing by an Angler, but republished by Humphrey Davy (New York: Freshet Press, 1970), 85-86. It describes two parent eagles who were teaching their offspring the maneuvers of flight. The introduction, however, indicates that the book is basically a fiction, but may in part be based on some real experiences. This reduces its value as source material considerably. G. R. Driver, "Once Again: Birds in the Bible," 56-57, however, quotes Yeoman's England (1934):135-6 and Bulletin of the Smithsonian Institution CLXVII (1937):302, both of which record instances which verify the description of Deut $32: 11$ and Exod 19:4.

${ }^{2}$ A. C. Bent on the authority of Dr. L. Miller from the United states in Bulletin of the Smithsonian Institution CLXVII [1937]:302, quoted in G. R. Driver, "Once Again: Birds in the Bible," 56-57.

"See article "Adler" in Reallexikon der Assyrio-
logie (Berlin: Walter de Gruyter \& Co., 1932), 1:36. 
At the same time it also conveys the idea of caring concern, as was mentioned above.

This concern is likewise present in the passages in Deut 1:31 and Num 11:12 where nāsa $\bar{a}^{2}$ is brought down on the human level. In these passages man is pictured as

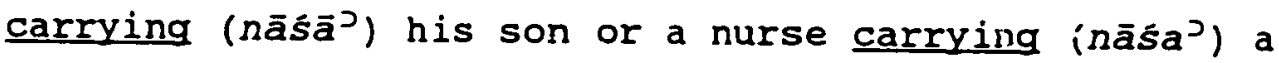
nursing infant (yonēg) in his bosom.' The fact that the images "father-son" and "nurse-young infant" are used implies that more is involved in the act of nāsa $\bar{a}^{2}$ than merely some impersonal physical transportation of an object. These images carry emotive overtones, implying intimacy, caring concern, and taking care of the needs of the object. ${ }^{2}$ The early versions have perceived this connotation and translated accordingly. LXX translates

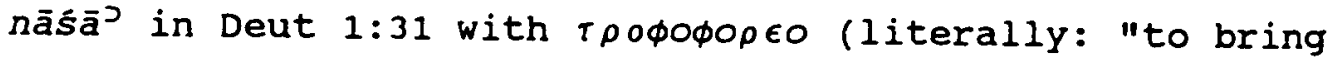
food"). This expression is translated in various ways. Some emphasize the caring aspect: "care for (someone) tenderly, bear in one's arms as a nurse," ${ }^{3}$ others relate it to more specific actions: "bring one nourishment,

\footnotetext{
${ }^{1}$ Cf. parallel idea in Hos $11: 3$ and Isa $46: 3-4$. In the latter nāśa is paralleled with Cămas "load, carry, ift" and sābal "carry, support." $5: 632$

${ }^{2}$ See Freedman and Wj.lloughby, "nāśă,$"$ TWAT (1986),

${ }^{3}$ William F. Arndt and F. Wilbur Gingrich, A GreekEnglish Lexicon of the New Testament and Other Early Christian Literature, 4 th ed. (Chicago: The University of Chicago Press, 1952), 835.
} 
sustain," while still others see it as referring to the functon of the mother: "suckle."2 Peshitta uses tarsi "to nourish, support, rear." ${ }^{3}$

This is what God has done for his people during the wandering in the wilderness, and this is a process he wants Moses to participate in. "Carry them in your bosom as a nurse carries a nursing infant," he commands Moses, and Moses clearly understands that this carrying involves more than just detached leadership or transport. In his reaction he worries that he will not be able to provide for their needs: "Where am I to get meat to give to all these people?"4 God responds by commanding Moses to appoint seventy assistants to share this burden with him. ${ }^{5}$

\footnotetext{
${ }^{1}$ Henry G. Liddell \& Robert Scott, comp., A Greek English Lexicon, 9 th ed., rev. Henry S. Jones, (Oxford: At the Clarendon Press, 1978), 1828.

${ }^{2}$ Geoffrey W. H. Lampe, A Patristic Greek Lexicon (Oxford: At the Clarendon Press, 1961), 1417.

${ }^{3}$ Probably taphel conjunctive from rsy. Jessie $P$. Smith, ed., A Compendious Syriac Dictionary (Oxford: At the Clarendon Press, 1957), 621.

This image is also found in the propkets where God is envisioned as a shepherd carrying his lamb (Isa 40:11). In that passage nāśa $\bar{a}^{2}$ is paralleled with nāhal "help along, lead carefully" (cf. Holladay, 230). In Isa 46:3 the context implies "taking care of" or "delivering" (mālat meaning "get one to safety"). See also E. Ruprecht, "פל pIt retten" THAT (1971), 2:423. In Isa $63: 9$ the context indicates that when God nāsajj the people it involved his sharing or participating in their afflictions and trials.

${ }^{5}$ Num 11:17.
} 
Again, the context indicates that the primary concern at this time was the "providing for" and "feeding" the people, or caring for all their needs. The people had been complaining about the food, and as soon as the seventy had been appointed to nāśa with Moses, God commanded the people to consecrate themselves in preparation for eating the meat which He was about to provide for them.' But it involved more. It involved taking the total responsibility for the people, their well-being, problems, and strife as a burden which Moses and his associates are to carry. They do that by supportively sharing in their condition, meeting their needs, and providing their necessities. Freedman has correctly pointed out that in this context nāsä involves eine warmherzige, liebende Fürsorge für das Volk. . . Ein Volk tragen heiBt, es zu lieben, schützen, seine Sorgen mitzutragen, aber auch seine Fehler mit anzutragen. ${ }^{2}$

All of these concepts form an informative background to Moses' plea to God in Num 14:19. He pleads for Israel that God might forgive their iniquity in the same way as He has nāsāj them from Egypt "until now." This is one of few cases where sālạ and nāsāo are used together in the old Testament. It is also found in the

\footnotetext{
'Num 11:18.

${ }^{2}$ Freedman and Willoughby, "nāsā'," TWAT (1986),
} $5: 632$. 
related context of Exod 34:9 and negatively in Deut 29:19. Sakenfeld has pointed out that in all these places sälah involves positively "the preservation of God's relationship to the community" and not simply the elimination of some particular act of punishment.' In fact, the subsequent verses indicate very strongly that God's forgiveness did not include a release from the consequences of the wrong action.

Indeed, as I live, all the earth will be filled with the glory of the Lord. Surely all the men who have seen My glory and My signs, which I performed in Egypt and in the wilderness, yet have put Me to the test these ten times and have not listened to my voice, shall by no means see the land which I swore to their fathers, nor shall any of those who spurned Me see it. - . I the Lord have spoken, surely this I will do to all this evil congregation who are gathered together against Me. In this wilderness they shall be destroyed, and there they shall die.?

This punishment, however, in no way annuls the assurance of forgiveness. Sakenfeld comments on this passage, that

the punishment does not mean that forgiveness has not already occurred, even before the people's repentance,

\footnotetext{
'Sakenfeld, "The Problem of Divine Forgiveness in Numbers 14," CBQ 37 (1975):327. Salah is only used in the context of forgiveness, and is therefore considered to be the terminus technicus for forgiveness. Only God is the subject of sālah. Its etymology has been debated. The root is common in semitic languages, but in most of them it has the idea of "sprinkling" or "pouring out" ( $\mathrm{HAL}_{3}$, 714). The same dictionary suggests a relationship with Ethiopic zalha "to create," whereas stamm points out that it might be related to Arabic slh "to undress" or "to come to an end." (THAT, 2:150-60).

${ }^{2}$ Num $14: 21-23,35$.
} 
nor that forgiveness understood as preservation of the community's relationship to God is any less real.'

That is the unexpected fact about forgiveness. It does not forget the wrong, neither does it necessarily remove the punishment. It is rather a supportive attitude and acceptance of the wrongdoer in spite of his wrongs.

\section{"Face" as Object \\ Nāsāa with "face" as object occurs six times in}

the Pentateuch," three times with the meaning of "be favorable to," "grant" (1), once indicating "respect," "honor" (2), and two times "be partial" (3). God is the subject in three passages $;^{3}$ and man, in three. ${ }^{4}$ The idea behind this image is clearly taken from well-known contemporary experiences. When a captive was brought in before a king, he threw himself down on the ground, indicating full submission. The king might indicate his pleasure concerning the captive by either stepping on $\mathrm{him}^{\mathrm{s}}$

\footnotetext{
'Sakenfeld, 326.

'Outside of the Pentateuch it is found 18 times: 1 Sam 25:35; 2:22; 1 Kgs $3: 14 ; 5: 1 ; 9: 32$; Isa $3: 3 ; 9: 14$; Zech $2: 4$; Mal $1: 9 ; 2: 9 ;$ Ps $82: 2 ; 4: 6$; Job $11: 15 ; 22: 26$; $32: 22 ; 42: 8,9 ;$ Lam $4: 16$. The context and usage in those passages is quite similar to that of the Pentateuch.

${ }^{3}$ Gen 19:21; Num 6:24，25; and Deut 10:17.

tGen 32:21; Deut 28:50; and Lev 19:15.

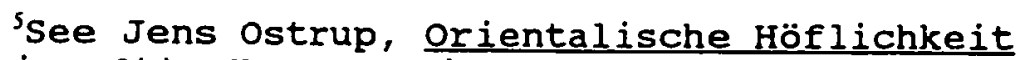
(Leipzig: otto Harrassowitz, 1929), 30-31: "Die vollkommenste Form der BegrüBung ist, daB man sich dem anderen völlig übergibt, indem man sich vor ihm
} 
or lifting/raising him up, either bodily or his face, when he was standing.'

Data

1. "Be favorable"

Gen $32: 21$

And you shall say, "Behold, your servant Jacob also is behind us." For he said, "I will appease ( Jakapperāh pānāyw) with the present that goes before me ( $I^{\prime}$ panāy). Then afterward I will see his face (pānāyw); perhaps he will accept me (yiš̄à pānāy).

Gen 19:21 And he said to him, "Behold, I

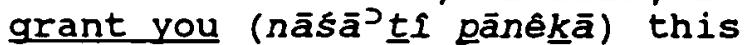
request also, not to overthrow the town of which you have spoken. . ."

Num 6:24, 25 The Lord bless you, and keep you; the Lord make his face shine upon you and be gracious unto you; the Lord lift up his countenance upon

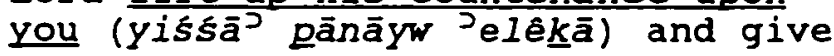
you peace.

niederwirft, daB er mit einem machen könne, was inm beliebe; er kann einem den FuB auf den Nacken setzen oder einen töten, man ist wehrlos." See also James $K$. Hoffmeier, "Some Egyptian Motifs Related to Warfare and Enemies and Their old Testament Counter-parts," The Ancient World, $6: 1-4$ (1983), 60, also fig. 3, page 62 .

'An interesting illustration of "favor" being implied by the lifting up of someone's head can be seen in James B. Pritchard, The Ancient Near East in Pictures (Princeton: Princeton University Press, 1954), 184, illustration 545, showing the goddess Isis, seated upon her throne, with seti I sitting on her lap. She is holding her hand under his chin, evidently "lifting up his face" toward her, so they are facing each other. The whole picture gives the impression of the goddess' acceptance and approval of the king. A related idea is also found in Akkadian, only with résu instead of panu:

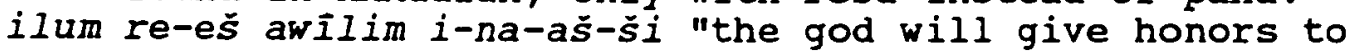
the man" (CAD, 108a). See also appendix D. 
Deut $28: 50$

A nation of fierce countenance who shall have no respect for the old

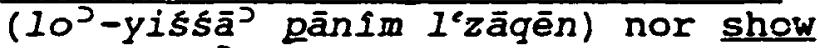
favor (10 $\left.y \bar{a} h 0^{2}\right)$ to the young.

2. "Be partial"

Deut 10:17

And the awesome God who does not show partiality $\left(10^{2}-y\right.$ iśs̄a pānsm), nor take a bribe.

Lev $19: 15$

You shall do no injustice in judgment; you shall not be partial to the poor $\left(10^{2}-t i s \bar{s}^{2} \underline{p}^{2} n e-d a l\right)$ nor defer to the great (welo'tehdar p'nê gādôl), but you are to judge your neighbor fairly.

Comments

In the first category (1) man is subject once and $^{\prime}$ God twice. ${ }^{2}$ An interesting wordplay on the word panim is found in the first passage. It occurs four times, one of which is the composite preposition lipnê with a pronominal suffix. On his way back to his home-country Jacob fears for his life as Esau approaches. In planning their first meeting, he expresses his hope that the gifts he is sending in advance may kāpar pānāyw (i.e., Esau's). The sequence is interesting. First, Jacob will kāpar his brother's face with a gift, then he will see his (i.e., Esau's) face, a process he hopes will lead Esau to lift his (i.e., Jacob's) face. In this context kāpar is seen

'Gen $32: 21$.

${ }^{2}$ Gen $19: 21$ and Num $6: 24,25$. 
as a process leading to the ultimate solution of the dilemma, the solution being in the form of an acceptance. Commentators have offered various suggestions as to the meaning of kāpar. Most dictionaries give "cover" as its basic meaning," while some commentators prefer "to clear, wipe away" based on Akkadian cognates. ${ }^{2}$ Even if either of these concepts could be, and have been "defended" etymologically, ${ }^{3}$ neither of them seems quite to

\footnotetext{
'See for instance KBL, 452, BDB, 497, Holladay, 163, based on the assumed meaning of $k p r$ in Gen 6:14. See also Claus Westermann, Genesis (Neukirchen-Vluyn: Neukirchener Verlag, 1981), 1/2:622. It should be noted, however, that the occurrence in Gen 6:14 is the only qal-form in the old Testament. All the other occurrences are in the intensive forms. Because the Qal context appears to indicate some kind of "coating," that meaning has been assumed for the other forms. That argument leaves much to be desired, however, since it is a known fact that the intensive forms frequently have a meaning different from the basic qal. Cognate languages do not seem to support that idea either. For a thorough examination of the etymology and meaning of $k \bar{p}$ ar see Bernd Janowski, Sühne als Heilsqeschehen;

Bernhard Lang, $7 \mathrm{~J}$ "kippar," TWAT, 4:303-18; and Gillis Gerleman, studien zur alttestamentlichen Theologie

(Heidelberg: Verlag Lambert Schneider, 1980), 11-37.

${ }^{2}$ See KBL, 452 .

${ }^{3}$ See for instance William $T$. Hyde, "The Hebrew Word kaphar and Its Greek and English Equivalents in Relation to the Doctrine of the Atonement" (B.D. thesis, SDA Theological Seminary, Takoma Park, MD, 1958) in which he shows how the idea of "cover" can fit and be defended in the respective passages. Three years earlier Albert $R$. Parker "successfully" did the same for the idea of "removing/wiping away" in his "Expiation and Propitiation in Relation to the conciliation concept of the Atonement" (B.D. thesis, SDA Theological seminary, Takoma Park, MD, 1955). Methodologically, however, both of them would be classic examples of "eisegesis" rather than "exegesis." Neither of them made an inductive contextual study of the texts involved.
} 
suit this context.' They even seem to be somewhat improbable. To "cover" Esau's face so he (Jacob) can see it makes no sense, and to "clear" it or "wipe [away the wrath?]" from it seems too literalistic. The context seems rather to suggest the idea of a process of restoration by means of some provisions. Jacob was interested in restoring his brother's favor towards himself by means of the gifts, so that he might be able to look him confidently in the face, hoping that Esau would then accept him. This becomes clearer in chap. 33 which describes their actual meeting. Vs. 10 reads:

Please, if now I have found favor in your sight, then take my present from my hand, for I see your face as one sees the face of God, and you have received me favorably (Emphasis added).

Some see the reference "I see your face as one sees the face of God" as referring to "the love and comfort that radiated from the presence of God" ${ }^{2}$ claus Westermann and others with him, see it rather as indicating that Jacob stands before Esau's face for the same purpose as he stands before God: to find mercy. He says

\footnotetext{
'In fact, some cognate languages, such as Aramaic, seem to support the idea of "to make provision for" as one of the meanings of kappar. In Sfire III:23 the noun $k p r$ means "storage-house," "house of supply/provisions" (KAI $1: 224$, p. 45). The question is whether $k p r$ in Hebrew cultic texts might also convey a similar idea.

${ }^{2}$ So Gerhard Ch. Aalders, Genesis, BSC, trans. william Heynen (Grand Rapids: Zondervan Publishing House, 1981), 2:150.
} 
Wie man das Angesicht Gottes sieht, um vor ihm Gnade $\mathrm{zu}$ finden ( $\mathrm{vgl}$. $\mathrm{Hi} 33,26)$, so ist er vor das Angesicht seines Bruders getreten, um $\left({ }^{c} l-k n\right)$ vor ihm Gnade, freundliche Annahme (rāṣāh) zu finden.'

still others see it as referring to the joy of meeting again with Esau, being like the appearance of a divinity in the sanctuary. ${ }^{2}$

Skinner ${ }^{3}$ and von Rad," however, see it as a reference to Jacob's experience at Peniel's when he met God and wrestled with him. "I have seen God face to face, yet my life has been preserved," is Jacob's reaction as he reflects on his conflict in the previous night. Now he has met his brother and the same has happened again, his life has been preserved even if he could only expect the opposite to happen. God's blessing and Esau's forgiving attitude have both really had life-preserving effects on Jacob, the receiver.

Esau confirms his forgiving attitude by suggesting that he join his brother on his travel, "Let us start our

'Westermann, 1/2:641.

${ }^{2}$ Ehrlich, 1:169.

${ }^{3}$ John Skinner, A Critical and Exegetical Commentary on Genesis, ICC (Edinburgh: T. and T. Clark, 1951), 414 .

tvon Rad, Genesis: A Commentary, trans. J. H. Marks (Philadelphia: Westminster Press, 1961), 322.

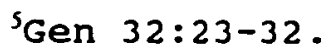

${ }^{6}$ Gen $32: 30$. 
journey and go, and I will go by your side (lenegdek̄ā)."l His proposal and Jacob's polite response, as he declines the offer, indicate their attitude of care and concern for each other. It is well in line with the total thrust of the whole pericope which is the restoration of the relationship between the two brothers. Both remembered the wrongs of the past, but they decided not to let them interfere with their present and future relationship.

Num $6: 25$ contains the so-called Aaronic blessing. It comes at the end of a series of priestly instructions, mostly concerning the vows of the Nazirites. Structurally the blessing has an interesting feature in the Hebrew. It consists of three cola, each of which is made up of two semi-cola, the first one "long," the other "short." Put together, each successive colon is longer than the previous, so the end result is an intensifying, progressive parallelism, where the first line in Hebrew

\footnotetext{
'Gen 33:12 (translation mine). Most translations translate this phrase as "go before," but the basic idea of neged is that of "presence." Ehrlich, quoting Rashi, has pointed out that the idea here is not "von dem gebraucht, was vornen ist, sondern von dem, was zur seite parallel läuft" (Ehrlich $1: 170$ ). He admits, however, that this is a late meaning, but still classical. It is also supported by Jacob's suggestion in vs. 14 that Esau go before them rather than staying behind with the slow movement of Jacob's family. This request would not make much sense if Jacob had just rejected Esau's suggestion that he go before the group as suggested by most translations of vss. 12 and 13 .
} 
has three words; second line, five; and the third, seven words.'

So entsteht durch zunehmende Zeilenlänge eine natürliche steigerung, die nach drei Anläufen in dem überlangen SchluBsatz ihren Höhepunkt findet.2

All the cola are basically parallel in thought with the main thrust of the Hebrew "Tat-Folge Relation." The first semi-cola all emphasize God's action, whereas the second are "but the concrete manifestation of a beneficient divine state" which indicate their effect on the recipient man. It appears that the key word of this passage, bārak, dominates not only the first line but the

\footnotetext{
'David N. Freedman has done a poetic analysis of the blessing in "The Aaronic Benediction (Numbers 6:24-26)," in No Famine in the Land: Studies in Honor of John L. McKenzie, ed. James W. Flanagan and Anita Weisbrod Robinson (Missoula: Scholars Press, 1975), 35-48. With one minor vocalic emendation he suggests the following pattern:

1st colon: $7+5=12$ syllables

2nd colon: $9+5=14$ syllables 3rd colon: $9+7=16$ syllables.

If accepted, this pattern offers an intervowen progression: the first semi-colon in cola 1 and 2 increases from 7 to 9 while the second remains the same ( 5 syllables), whereas the first semi-colon in cola 2 and 3 remains the same, while the second increases from 5 to 7 .

${ }^{2}$ Klaus Seybold, Der aaronische Segen. Studien zu Numeri $6,22-27$ (Neukirchen-Vluyn: Neukirchener Verlag, 1977), 19 .

${ }^{3}$ Ibid. , 38.

tMichael Fishbane, "Form and Reformulation of the Biblical Priestly Blessing," JAOS 103:1 (1983):116. See also Patrick D. Miller, "The Blessing of God," Interpretation 29 (1975):243.
} 
whole formula.' "The Lord bless you, and keep you" is actually the all-inclusive blessing. "Wenn Gott segnet, dann erbietet er . . nicht nur ein segenwort sondern eine Tat . . die mit Fruchtbarkeit, Lebenskraft, Glück, Gedeihen identisch ist."2 The parallel expressions in cola 2 and 3 merely explicate its meaning while they, at the same time, narrow it down, focusing it on the final word, šâlôm. This concept is also found in parallel

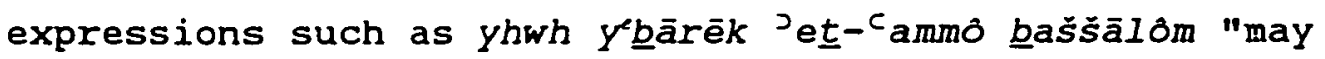
the Lord bless his people with peace." ${ }^{3}$ The Aaronic blessing concretizes God's blessing to "keeping": "may he keep you (weyišmerekā)." God's protective care is found in many places in the old Testament and is often likened to that of a shepherd caring for his flock. ${ }^{4}$

"The Lord make his face shine upon you and be gracious unto you." The "enlightened face" of a divine being was, in Ancient Near Eastern circles, seen as an evidence of friendliness, attention, and favor of a

'Ibid., 37.

${ }^{2} J o s e p h$ Reindl, Das Angesicht Gottes im Sprachgebrauch des Alten Testaments (Leipzig: St. Benno-Verlag, $1970), 128$.

${ }^{3}$ Ps 29:11. Other parallels include Ps $134: 3 ;$ and $115: 12$.

'See for instance Ps 121:5-8 where the Lord is presented as the šomer who šamar his people from both physical and spiritual dangers. See also Jer 31:10. 
superior toward someone inferior.' often it is almost synonymous with rāṣôn "pleasing, favorable."2 An interesting parallel is found in a prayer to Ištar: damqāti ināki libša elīja ina būnīki namrūti kiniš naplisinni jåši

Deine glitigen Augen mögen sich auf mich richten, mit deinem leuchtenden Antlitz blicke mich freundlich an. ${ }^{3}$

The light of God's face is thus simply an

illuminous expression for his grace or mercy which he shows towards his people. It is "nirgends eine nur allgemein gnädige Gesinnung besagt, sondern immer den greifbaren Gnadenerweis oder die erwartete tatkräftige Hilfe." It is a well-accepted fact of life that von einem, dessen Antlitz leuchtet, der also froh und glïcklich ist, ist es leichter eine Gnade zu erlangen,

\footnotetext{
${ }^{1}$ Cf. Marjo C. A. Korpel, "The Poetic structure of the Priestly Blessing" JSOT 45 (1989): 6 .

${ }^{2}$ So for instance Ps $44: 3$, last part, "Thy right hand, and Thine arm, and the light of Thy presence, for Thou didst favor them."

${ }^{3}$ Quoted Oswald Lorenz, "Altorientalischer Hintergrund sowie inner- und nachbiblische Entwicklung des aaronitischen Segens (Num 6,24-26)" UF 10 (1978):117. Friedrich Nötscher, "Das Angesicht Gottes schauen" nach biblischer und babylonischer Auffassung (Darmstadt: wissenschaftliche Buchgesellschaft, 1969), 13, points out that in Akkadian the ideogram for damqu "gnädig" is composed of the sign igi (pânu) "eye, face" and làh "bright, shining." Compare also an expression by Asshurbanipal: "Ich sah inn freundlich an und richtete auf ihn mein gnädiges Antlitz."
}

${ }^{4}$ Reindl, 129. See also Korpel, 6, who points out that the light of the face of God can save Israel (Ps $44: 4$ ) and people can only be happy if they can walk in that light (Ps $89: 16$ ). 
als von einem, der finster blickt, also betrübt und zornig ist... . Seinen Antlitz über einen anderen leuchten lassen, heiBt darum gnädig, huldvoll, nachsichtig sein, so daB er keine Furcht zu haben braucht. ${ }^{1}$

The final line of the benediction contains two hapax legomena, neither of which has an exact parallel. The first of these is the expression nāsà pānim ${ }^{2} \bar{e} l$. It occurs only here with a divine subject, but when used with a human subject, it usually has the sense of literally looking up or metaphorically to face someone with confidence. ${ }^{2}$ In the context of Num 6:26 it clearly denotes a favorable attitude of a superior towards someone inferior.

This concept is supported by Mesopotamian texts from the ninth and sixth centuries B.C., one of which describes how the goddess Gula, pa-ni-šu tu-sah-hi-ram-ma ina bu-ni-ša nam-ru-ti kiniš tap-pal-sa-añ-ni-ma túš-ri-im-mi ra-am-ma.

\section{'Nötscher, 12-13.}

${ }^{2}$ In 2 Kgs $9: 32$ it is used about Jehu turning his face upward, "looking up," to the window where Jezebel was standing. In 2 sam 2:22 Abner refrains from killing Asahel, for, he said "How could I lift up my face ( $e s \bar{s} \vec{a}^{2}$ pānay) to your brother Joab?" meaning: facing him with a good conscience. In Job 22:26 Eliphaz states that if Job returns to the Lord he will be restored and be able to

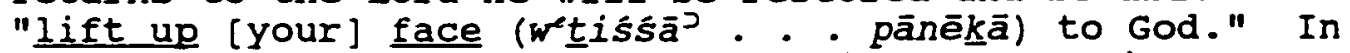
I Sam 25 it is associated with the idea of forgiveness. Vs. 28 tells about Abigail asking David to "please, forgive the transgression ( $\left.\hat{s}^{p}-n \bar{a}{ }^{p} l^{e} p e s a^{c}\right)$ of your maidservant." In his response David claims, "I have shown

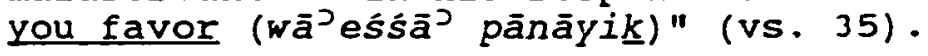


turned her countenance toward me (viz, Nabuna ${ }^{3} i d$ ); with her shining face she faithfully looked at me and actually caused (him; i.e., Marduk) to show mercy.'

In contrast to "letting the face fall" which indicates anger ${ }^{2}$ or displeasure, ${ }^{3}$ God's lifting his face towards someone will result in his granting peace. The expression śim šâlôm is only found once more in the old Testament $t^{4}$ wereas the parallel word-pair nāsā’ pānfm // śim šălóm is only found here. The usual expression is

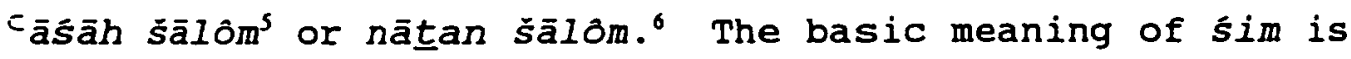
"determine, fix," in contrast to the other two expressions, nātan and ' $\bar{a} s \bar{s} h$, which are more general terms, often indicating the inception of an event whereas sim has more of a durative aspect, the establishment of a durative action (here: peace). Seybold ${ }^{8}$ points out, in accordance with Reindl, that this text is actually a

'Quoted in Michael Fishbane, 117. Korpel, 6, points out that in Babylonian pana našu means "to care for."

${ }^{2}$ Jer $3: 12$.

${ }^{3}$ Gen $4: 6$.

HPs $147: 14$.

${ }^{5}$ Found five times in the old Testament: Josh 9:15, Isa $27: 5(2 x) ; 45: 7 ;$ and Job 25:2.

${ }^{6}$ Lev $26: 6$ and Hag $2: 9$.

'See KBL, 920 .

${ }^{8}$ Seybold, 40; also note 6 .

'Reindl, 130. 
prayer that God may determine or appoint peace as the destiny of the people, with the emphasis on peace as something enduring rather than just some momentary lull in troublous times.

Šàlôm has been defined as "freedom from all disaster," "good health, prosperity, happiness, both this worldly well-being and a right relationship with God,"2 "state of wholeness," "being complete so that nothing is missing . . includ[ing] everything an individual or community needs for well-being and prosperity," "das unfassendste Heilsgut, der Inbegriff vollkommensten Glückes,"s and "the perfect peace or condition where all things function in harmony and nothing is wanting."6 The thrust of the Aaronic blessing is thus a plea that God may show his favorable attitude toward his people through active protection and unmerited assistance and

'G. B. Gray, 73.

${ }^{2}$ John Sturdy, Numbers (Cambridge: Cambridge University Press, 1976), 55.

${ }^{3} M$. Noth, Numbers, A Commentary, OTL, trans., J. D. Martin (London: SCM Press, 1968), 59.

'Arie Noordtzij, Numbers, BSC, trans. Ed. van der Maas (Grand Rapids: Zondervan, 1983), 69. See also Reindl, 130.

${ }^{5}$ Reindl, 130 .

${ }^{6} \mathrm{~A}$. Murtonen, "The Use and Meaning of the Words lébārēk and $b^{c} r \bar{a} \underline{k} \bar{a}$ in the old Testament," VT 9 (1959):162. 
provide them with whatever is needed for maintenance of a harmonious, happy life.'

This same concept of favor is also present in Gen 19:21 where Lot is pleading with God that he and his daughters need not flee any farther than zoar. God responds by saying, "I have favored you (nāsā’tí pānêkāa) also in this thing." The "also," gam, does not imply that this is one of many of Lot's requests which God is going to answer, ${ }^{2}$ but rather that God has again in this matter shown his favorable attitude toward Lot. Earlier his angels had led Lot, his wife, and daughters out of the doomed city of Sodom. This agrees with Lot's admission in Gen 19:19 that he had already found favor before the Lord. Now the Lord adds another favor. The first was unsolicited; the second upon request.

The two texts, Num $6: 25$ and Gen 19:21, use expressions which are morphologically, syntactically, and semantically similar but with a somewhat different intent.

\footnotetext{
'This idea is apparently also present in Ps 4:6-8 even though there is an ongoing discussion among scholars about the meaning of nāsāh. In general, however, most commentators do not comment on this issue but appear to accept it as a variant (spelling?) of nāsà'? The context combines the idea of "lifting up(?) the light of his countenance" which will result in "gladness in my heart, peace and safety" which is apparently a paraphrase of the Aaronic blessing in Num 6 .

${ }^{2}$ So Westermann, 1/2:371-2, who claims that "the misplacement" of this passage indicates that it is a later addition. Such explanation is, however, not warranted by the text.
} 
Both use the expression nāśă pänsm, expressing the idea of beneficence and/or favor towards the receiver. The first one refers to the "lifting" of the subject's own face; the latter, that of the recipient of the action. In both cases, however, the effect is the same: a favorable attitude by the subject toward the recipient.

In one of the passages in this category, Deut 28 : 50, the expression nāsā’ pānfm is used in the more general sense of "showing respect." "The statement is a prophetic warning about the coming of a nation having a "fierce countenance" which will neither respect/be favorable to (In $n \bar{s} \bar{s}^{\supset}$ pānim) the old nor favor (yạhon) the young (i.e., it will completely disregard everyone's basic needs and rights "until they have caused you to perish)."2

The last two passages, Deut 10:17 and Lev 19:15, also deal with a certain aspect of "favorable attitude" towards someone. This time, however, the sense implied is restricted to the idea of favoring someone over against someone else (i.e., taking sides). Both these passages are in the negative. Deut 10:17 sets the stage by referring to God as an example of one who does not favor one over another. This idea is not brought out by the

\footnotetext{
'This idea is also found in several texts outside of the Pentateuch: 2 Kgs $3: 14 ; 5: 1$; Isa $3: 3 ; 9: 1 ;$ and Lam $4: 16$.

${ }^{2}$ Deut $28: 51$
} 
expression itself, but rather by the context which parallels the expression nāsā’ pānfm with "not taking bribe" (10` yiqqaḥ sohạd), and explains it further by stating that God "executes justice for the orphans and widows" and provides the alien with food and clothing.' on the surface, it may appear that this presents a contradiction. The initial phrase states that God does not nās̄à pānìm, which usually indicates "showing favorable attitude" towards someone, but then it is expanded to indicate how he does take care of the needy. The thrust of the context indicates, however, that God will not be bought to show favor to someone "meritorious" at the expense of a less favored one. God is not only favorable towards those who may think they merit it, his care is needs-oriented rather than status-oriented.

Based on this trait in God's character, his people are commanded not to let any status in society, be it high or low, influence their sense of justice. "You shall do no injustice in judgment; "You shall not be partial to the

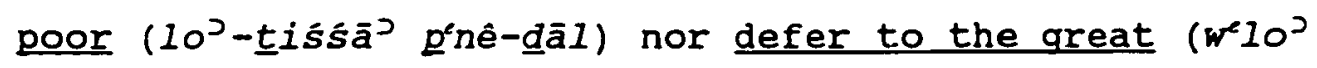
tehdar penê gāaôl), but you are to judge your neighbor fairly."2 This stipulation comes within a series of laws dealing with social order. Vs. 13 prohibits oppression

\footnotetext{
'Deut 20:17-18.

${ }^{2}$ Lev $19: 15$.
} 
and theft and requires prompt payment of wages; it also prohibits taking advantage of those who are handicapped, thus making life difficult for them. Then there are the stipulations that no injustice be done in judgment, whether the subject be rich or poor. Taken by themselves, these stipulations may appear to contradict other passages in the Bible which speak critically of those who do not show favor to certain classes.' In this context, however, it is clear that the emphasis is on the importance of judicial equality. The judge is not to regard the status of those being judged. All are to be equal before the law, and the same law is to be applied to all persons.' The poor should not be favored because they are poor, neither are the powerful to receive preferential treatment on account of their power or wealth. ${ }^{3}$

'See for instance Deut 28:50; also the emphasis on social justice in the prophets such as Amos.

${ }^{2}$ Cf. Exod 23:2-8; Deut 16:19-20; Zech 8:16. See also Abram Menes, Die vorexilischen Gesetze Israels, BZAW 50 (Giessen: Verlag von Alfred Töpelmann, 1928), 34-36; and A. Noordtzij, Leviticus, BSC, trans. Raymond Togtman (Grand Rapids: Zondervan Publishing House, 1982), 198. Similar concerns are also found in Ps $82: 2--" H o w$ long will you judge unjustly, and show partiality to the wicked

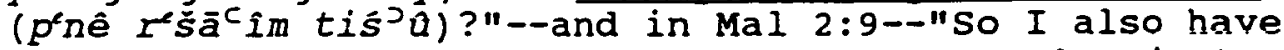
made you despised and abased before all people, just as you are not keeping My ways, but are showing partiality (noś'Im pānim) in the instruction."

${ }^{3}$ Ehrlich, 2:64, wants to emend tišsāj with tāsēb in agreement with 1 kgs $2: 16,17,20$, meaning "You shall not turn the poor away." He claims that the contrast between dāl and gãdôl requires it. That emendation seems, however, completely unjustified. The text is perfectly 


\section{"Head" as Object}

In two Pentateuchal passages where nāsā’ is used with "head" as object, the emphasis appears to be on attitude or relationship rather than a literal lifting per se.' Both of these passages are within the same narrative, the early part of the story of Joseph, and the subject in both is man.2 The author makes an interesting play on words in this passage between the literal use and the metaphoric.

Data

Gen $40: 13$

Within three wore days Pharaoh will lift up your head (yiśsa ${ }^{2}$

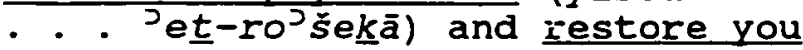
(wah's $\left.{ }^{a} \underline{b} k \bar{a}\right)$ to your office. . . .

[Gen $40: 19^{3}$ ] [Within three more days Pharaoh will lift up your head from you

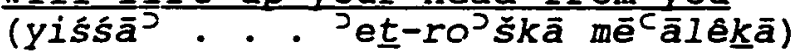

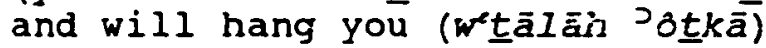
on a tree.]

clear as it stands, and the context does not seem to be contrasting the two classes but rather putting them on an equal footing as far as the law and justice is concerned.

'See pages 154-58 above where the literal meaning of this expression is discussed.

${ }^{2} \mathrm{~A}$ third passage in which a literal meaning of $n \bar{a} \bar{s} \vec{a}^{2}$ is employed is included here for the sake of continuity since it is used within the same pericope and is quite closely tied to the other two. It is also important as a contrast and comparison for the other two.

${ }^{3}$ This passage does not really belong in this category since it deals with a literal meaning of nāsā' It is, however listed here for comparison and completeness. 
Gen $40: 20$

Thus it came about on the third day - . that he $\dot{j}$ lifted up the head (wayyiśsáj jet-ro's) of the chief cup-bearer and the head ( $w^{2}$ et $\left.t-r O^{\prime} \breve{s}\right)$ of the chief baker among his servants.

\section{Comments}

The story is familiar. As Joseph interprets the dreams of the butler and baker he makes an interesting and important play on different meanings of nāsia $\bar{a}^{2}$. To the butler he says, "Within three more days Pharaoh will lift up your head and restore you to your office (yiśs $\vec{a}^{\prime}$. . .

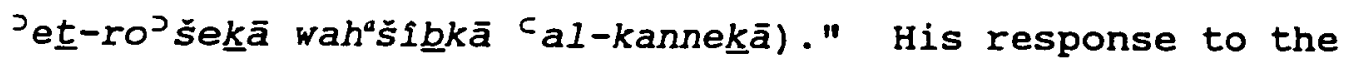
baker is structurally parallel, but has an iroric, fateful twist to it; "within three more days Pharaoh will lift up your head from you and hang you upon a tree (yissá) . . ' et only real structural difference between these two statements is the inclusion of the prepositional phrase $m \bar{e}^{c} \bar{a} l e \underline{k} \bar{a}$ in the latter. The key phrase in both responses is the same: $y^{i s s^{\prime}} \bar{a}^{J}$ parcoh Jet-ro’skā "Pharaoh will lift up your head." The fact that the author feels a need to qualify the expression in both cases indicates the neutrality of the expression itself. Only the context fills it with meaning. This is further exemplified in vss. 20-22,

On the third day . . . he lifted up the head (wayyiśśa $\bar{a}^{2}$ et-ro's) of the chief cup-bearer and the head ( $w^{2}$ et ro $\left.0^{3}\right)^{\prime}$ of the chief baker... and he 
restored the chief cup-bearer to his office . . . but he hanged the chief baker, just as Joseph had interpreted to them.

Some scholars see the expression $n \bar{a} \bar{s}^{2}$ ro $O^{2}$ s as a technical term for "taking up a case for review" ; others see it as a technical expression for "release from prison." 2 still others take a rather superficial view of this expression, that it "refers to [the act of] being raised up from a position of humiliation and dishonor to a position of honor and acceptance." ${ }^{3}$ All of these, however, seem to miss the real thrust of the passage by restricting the phrase to that of a technical expression. The author appears to make use of the neutrality of the expression in order to bring out the pun and let the context bring out the intent in each case. Von Rad has correctly pointed out that

this expression goes back ultimately to an actual custom in an audience: the petitioner stands or kneels

\footnotetext{
'Ehrlich, 1:201-2. He explains that some time after a crime was committed the ruler might have the "main points" (ro's) (or: "the sum of the matter" cf. Ps $119: 160$ ) of the case brought (nas̄à) to his attention in order to review it. At that time a previous judgment might be overturned. He bases this argument only on this passage and Jer $52: 31$, which refers to the release of king Jehoiachin during the Babylonian Exile. See also Anthony Phillips, Ancient Israel's Criminal Law (Oxford: Basil Blackwel1, 1970), 27; and Ephraim A. Speiser, "Census and Ritual Expiation in Mari and Israel" BASOR 149 (1958):21. $52: 31$.

${ }^{2}$ So J. Skinner, 462 ; cf. also $2 \mathrm{Kgs} 25: 27$; and Jer

$$
{ }^{3} \text { Aalders, } 2: 208 \text {. }
$$
}


with bowed head while the one on the throne takes him under the chin and raises his head.'

In that sense it is somewhat parallel to nāsā pānfm

"being favorable towards," but it goes apparently further.

on both occasions where this expression is used in this

sense in the old Testament, ${ }^{2}$ it implies not only a

favorable attitude but also a restoration to honor. The

butler was restored to his original post and place in

society, and so was king Jehoiachin during the exile.

\section{"Place" as Object}

In two passages in the Pentateuch "place" is the object of nāsáa . Both of them are a part of the same pericope, and even the same verbal exchange between God and Abraham, with God as the subject.

\section{Data}

Gen $18: 24$

Wilt thou Indeed sweep it away and not spare the place (weI0 lammãqôm) for the sake of the fifty righteous who are in it?

Gen 18:26 If I find in sodom fifty right-eous within the city, then I will spare the whole place (w'nàsás ț I'kolhammāqom) on their account.

\footnotetext{
'von Rad, Genesis, 367. See also appendix D.

${ }^{2}$ Here in the Pentateuch and 2 Kgs 25:27 (a parallel passage is found in Jer $52: 31$ ).
} 


\title{
Comments
}

\begin{abstract}
Abraham is pleading for the life of the inhabitants in Sodom and Gomorrah, following God's proclamation of their doom. It is clear from the context that "place" is used metonymously for the people who lived inside the city boundaries. It was the people of these cities who were wicked, not the places themselves. So it was also the people who were about to be punished. For this reason it is justifiable to include it in this context. Dillmann' suggests an amendation of the text by adding ' $\bar{a} w o ̂ n$ or pešac as objects for nāsā' thus reading "take away (or: forgive) the wickedness/rebellion of the place for the sake of the fifty righteous."2 The context, however, does not demand such emendation. Abraham does not appear to be asking forgiveness for the wrongs of the people, as Moses did at a later time; ${ }^{3}$ rather he appears to be concerned about the survival of those who lived in the city, especially his relatives. The question is not so much about "forgiveness" of sins as the avoidance of
\end{abstract}

'August Dillmann, Genesis Critically and Exegetically Expounded, trans. William B. Stevenson (Edinburgh: T. and T. Clark, 1897), 2:100 based on texts such as Num 14:19; Isa $2: 9 ;$ and Hos $1: 6$.

${ }^{2}$ This reading is also suggested by Keil and Delitzsch, 1:231.

${ }^{3} \mathrm{Cf}$. Moses' intercession in Exod $31: 32$ and Num $14: 19$. 
their consequences and caring concern for those who lived in these cities.'

Westermann $n^{2}$ has pointed out that what is involved here is "nothing more than [a request] to annul the decision to destroy." In the light of other usages of nāśă' however, more is clearly involved than simply a decision for solne non-action. Most usages of nāsá̀ are action-filled for the benefit of the receiver. God's promise to nāsā’ the place apparently implies his willingness to be favorable towards the place and even to help it prosper on account of the presence of the righteous ones in the city. ${ }^{3}$

\section{Unspecified object}

The last passage in the category of interpersonal relations, Gen $4: 7$, is problematic, and as such has invited interpretations which are almost as numerous as their proponents are many. The history of its interpretation goes back to the ancient versions and

'This usage fits very well with similar usages in Akkadian, a language and culture with which Abraham would have been well acquainted from his years of growing up in Ur. On this meaning in Akkadian, see pages 59-60 above.

${ }^{2}$ Westermann, 1/2, 355 .

${ }^{3}$ The positive intent of nāsaj is well illustrated by its use in the expression "to deal justly." The context implies that for the many unrighteous ones to benefit from the presence of a few righteous ones would be "to deal justly," whereas for the few righteous in the cities to suffer because of the unrighteous, would not be just. 
traditions. The reason is that the text is very cryptic in style and presents both syntactical and morphological anomalies. All of these leave it wide open to speculation.

\section{Data}

Gen $4: 7$

If you do well, will not your countenance be lifted up ( $\left(^{e J} \bar{e} t\right)$. And if you do not do well, sin is crouching at the door; and its desire is for you, but you must master it.

\section{Comments}

Procksch has called this text "the most obscure verse in Genesis," I and Westermann claims that no satisfactory explanation of these two verses ( 6 and 7 ) has been proposed as yet. ${ }^{2}$

There are four major syntactical problems: (1) $\hat{s}^{e D} \bar{e} t$ is apparently a qal infinitive and forms by itself an unattached apodosis for the conditional clause

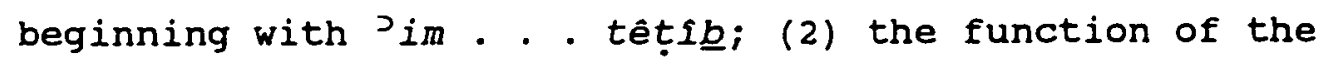
prefixed preposition in lappetah; (3) the gender

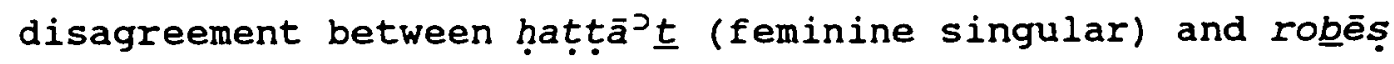
(masculine singular), and finally (4) the final word bo is

\footnotetext{
'Procksch, quoted in Gordon J. Wenham, Genesis 1-15, word Bible Commentary (Waco: Word Books Publishers, 1987), $1: 104$.
}

${ }^{2}$ Westermann, 1/1:406. 
masculine singular, whereas the assumed antecedent hatțta $\bar{a}^{\top} \underline{t}$ is feminine.

It is beyond the scope of this research to attempt to find a solution to these complex problems, ${ }^{1}$ but despite them, the general meaning seems to be relatively clear. Cain's attitude in vs. 5 is wrong, and God warns him of the danger if he does not change. For our purposes the crucial word is $\bar{s}^{e \supset} \bar{e} \underline{t}$. It has been taken as a noun for (1) forgiveness in general, ${ }^{2}$ (2) God's acceptance of Cain and his offering, ${ }^{3}(3)$ lifting up of Cain's spirit as opposed to his depression, ${ }^{4}$ and (4) literal straightening up of cain's posture in contrast to the crouching of sin. Even though all of these positions are theoretically possible in light of the text, it seems that the first two are most in line with the immediate context and the general usage of nāsãa .

Vs. 5 indicates that cain's face "fell" and he became angry when he realized that Abel's sacrifice was

'For a discussion of the issues involved and relevant literature see Westermann, 1/1:406-410; G. J. Wenham, Genesis 1-15, 92, 104-6; Aalders, 122-3; and $J$. Skinner, 106-7 (footnote).

${ }^{2}$ Wenham, Genesis 1-15, 93, 105.

${ }^{3}$ So Calvin, König, and Kidner, quoted in Wenham, Genesis 1-15, 105.

'So Speiser, Keil and Delitzsch, von Rad, and Westermann (also quoted in Wenham, Genesis 1-15, 105).

sSo Cassuto, quoted in Wenham, Genesis 1-15, 105. 
acceptable to the Lord, whereas his own was not. The Lord then gives cain an opportunity to assess the situation and get to the root of the problem. In the process the Lord analyzes the problem and places it squarely before cain in four steps:

1. Introduction--Why are you angry? Why is your face "fallen?"

2. General statement--If you do weli [there is] $\dot{s}^{e J} \bar{e} t$.

3. Problem--If you do not do well [there is a problem awaiting]. Sin robēs at the door, waiting to enter. "It" desires you.

4. Admonition-you must master "it."

In light of the structural flow of the whole passage it seems most natural to see $\dot{s}^{e J} \bar{e} t$ in contrast to nappal in the previous verse. Cain was angry and his face was "fallen" because of God's non-acceptance of him and his sacrifice, but cain was aware that the wrong was on his part. God confirms that if cain was right, or made things right, there was no need for him to go around with a "fallen" face; a $\bar{s}^{e} \bar{e} \underline{t}$ action was available to him, and his face could be lifted up (cf. nāsāa pānim = acceptance). An ongoing wrong-action, however, would prepare the way for a greater evil--the control of sin over cain, but he must take control of his life, and by mastering the 
"enemy" he would avail himself of the state of acceptance' being reflected in his physical posture.

\section{Summary}

In certain contexts nāsāo implies an attitude of loving concern for and an intimate relationship either between God and man or between persons. God is seen as One who cares for his people, like a father who carries his child or an eagle caring for her young. This implies intimacy and a caring concern for their needs. God also invites leaders to participate in this caring concern for the people by sharing in their situation, meeting their needs and providing for their necessities. This supportive attitude is at times equated with the concept of forgiveness. The wrong may not be forgotten nor is there necessarily a release from the immediate conse-

\footnotetext{
'This appears to be more in line with the general usage of the expressions nāpal pānsm and nāsāo pānim than simply considering them as indicating the physical downcast eyes and uplifted face (so Aalders, 1:122, and von Rad, Genesis, 101). As to the problematic gender disagreement between hatțāt $t$ and robēs, both Ehrlich $(1: 20)$ and von Rad (101) suggest the same solution: to look upon the final taw of hatta ${ }^{2} t$ be taken as the initial taw of rbs, reading tirbas which may be either third person, feminine singular; agreeing with hatt $\bar{a}{ }^{\supset}$, meaning "sin will lie in wait" (von Rad), or as secónd masculine singular, which together with the meaning "opportunity" for pth (cf. Hos 2:17) Ehrlich reads: "If not. . . you will lie under (or "be crushed under" cf. Exod 23:5) the [first] opportunity for sin" (p. 21). This latter suggestion seems very strained and requires several adjustments and emendations. Von Rad's suggestion appears much more viable.
} 
quences, but neither is it any longer permitted to adversely affect the relationship between the wronged and the wrongdoer.

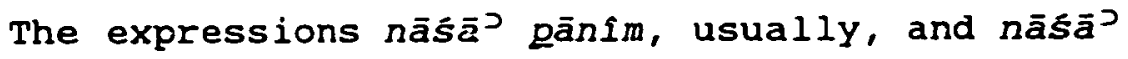
ro's, sometimes have the connotation of acceptance or "be favorable towards." It is an outward sign of an approved friendship, in spite of eventual wrongs, and may at times be seen as parallel with the process of "atonement" (kpr). This process is, however, not automatic. It calls for cooperation. Acceptance may be made available, but it only benefits the wrongdoer if he submits to its stipulations. $N \bar{a} \bar{a}^{\prime}$-forgiveness is not just a matter of some ceremonial rubber-stamping, rather it represents a sustained, favorable attitude. In reality, in the context of interpersonal relations, nāšă takes persons as objects which are carried by a caring individual who is concerned about their well-being, shows them favor, and accepts them in spite of their wrongdoings.

The question which now remains is how, or if, this concept fits in with the general meaning of nāśa $\bar{a}^{2}$, and whether it can be justified in the light of other more traditional words for forgiveness. 
CHAPTER VII

$N \bar{S}^{\supset}$ AND FORGIVENESS

Is the concept of "forgiveness" really present within the semantic range of nās $\bar{a}^{2}$ ? Present research has shown that it is generally considered to be based on a derived meaning of nāsāj rather than being one of its "basic" meanings.' Therefore, the question may arise whether that meaning is exegetically justified. As traditionally defined, forgiveness is usually associated with a repairing of shortcomings, either in the context of meeting a set standard or in relationships. ${ }^{2}$

Present research has brought to light three areas within which this concept is most likely to occur in the context of nāsā’ The first category is linguistic. It is generally accepted that the terms $k p r$ (piel) and sălah

'Chap. 1 pointed out that practically all lexica placed "forgive" at the end of a long list of meanings, almost as an afterthought.

${ }^{2} \mathrm{Cf}$. the following definition by Bernhard Lang, "כפר kippær," TWAT (1984), 4:307: "Wenn ein positives oder neutrales Verhältnis zwischen zwei Gruppen oder Partnern durch Verbrechen, Fehler oder Sünde gestört wird, entsteht eine Spannung; diese muB . . . neutralisiert und aufgehoben werden, so daB die gewöhnliche ordnung wiedehergestellt ist. 
are in a sense termini technici for forgiveness in the Pentateuch, and other similar terms, such as ksh (piel) and rāpāh, are frequently used in that sense outside that corpus.! The second category is theological. The sanctuary service in general, and the sacrifices in particular, dealt with the sin-problem in the old Testament, a process involving forgiveness. ${ }^{2}$ Finally, there are certain social situations within which some reconciling actions are called for. ${ }^{3}$ The question is now how the various meanings of nāsiaj fit into the picture.

\section{Linguistic Basis}

\section{$N \bar{a} \mathbf{s} \vec{a}$ "and "kpr"}

In three texts within the Pentateuch, nāśa is used in parallel with kpr (piel), Gen 32:20; Exod 32:30, and Lev 10:17. In the first, Jacob is returning from his "exile" after twenty years of servitude." As he approaches Canaan he knows he will have to face his

'See Helmer Ringgren, "נס kāsāh," TWAT (1984), 4: $272-77$, and Hans Joachim Stoebe, "î่ rāpāh, "THAT $(1976), 2: 808$.

${ }^{2} \mathrm{Cf}$. William Dyrness, Themes in old Testament Theology (Downers Grove, IL: InterVarsity Press, 1979), 157-58; and Elmer A. Martens, God's Design (Grand Rapids: Baker Book House, 1981), 52-59.

${ }^{3} \mathrm{Cf}$. the experience of the brothers of Joseph in Gen $50: 15-21$.

Gen $31: 41$. 
brother Esau with whom he had driven a hard bargain' and finally cheated out of his inheritance. ${ }^{2}$ There was clearly a tension in their relationship which made Jacob quite apprehensive as he prepared to meet his brother. In the process he planned to "kpr" his brother's "face" by means of the gifts which he sent ahead of him in the hope that he might then see his brother's "face" and he (Esau) would then (hopefully) accept (nāsā') Jacob's "face."3

It is clear that in this context the process of "kpr" is seen to be a means of obtaining nāsáa. The two terms are apparently not quite parallel here, even though their purpose is basically the same: to obtain favor with Esau and restore the relationship with him.* Even though "kpr" is usually only translated "forgive" when God is the subject, it is always associated with the restorative process between estranged individuals or between God and $\operatorname{man} .^{5}$

This is also the case following the "golden-calf" experience in Exod 32. A few weeks earlier the people had entered into a covenant with God, in which they

\footnotetext{
'See Gen 25:30-34.

${ }^{2}$ Gen 27 .

${ }^{3}$ Gen $32: 20$.

${ }^{4}$ Cf. Gen $33: 8,10$.

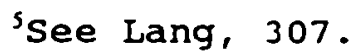


acknowledged that he had delivered them out of Egypt and they would therefore be loyal to him.' As Moses was delayed on the mountain the people grew tired of waiting for him and decided to turn their worship and loyalty over to a god of their own choice--a god who, they claimed, had brought them out of Egypt. ${ }^{2}$ By that action they, in fact, rescinded the covenant terms, which demanded absolute loyalty to the sovereign. God was, therefore, no longer "duty-bound" to protect the nation. It was within the framework of the covenant that God had even the full "right" to appear to them as an enemy, a destroyer. ${ }^{3}$ At this point Moses decided to intervene on the people's behalf, and he said to the people,

You yourselves have committed a areat sin $\left(h^{a} t a^{2}\right.$ tem $h^{a} t \bar{a}^{D} a h$ ǵdolāh); and now I am going up to the Lord, perhaps I can make atonement ( $\left.{ }^{a} k a p p e r a \bar{h} h\right)$ for your sin.t

As he returned to the Lord he confessed the people's wrongdoing and asked God to forgive (nāśa $\bar{a}^{2}$ ) their sin.s Thus, making atonement $(k p r)$ for their sin and forgiving

'See Exod 19:8 and 20:2, 3 .

${ }^{2}$ Exod $32: 8$.

${ }^{3} \mathrm{Cf}$. the curses in ancient treaties such as sfire I and others. Dennis J. McCarthy has also pointed out in his Treaty and Covenant (Rome: Biblical Institute Press, 1978), 137 that whoever was not an ally or a vassal was considered an enemy.

'Exod $32: 30$.

${ }^{5}$ Exod $32: 32$. 
(nāsā' their sin are seen as parallels, but not necessarily synonymous. But the "kpr"-process is again presented as a means of obtaining näsāj-forgiveness. In the story of Jacob it was obtained by means of a generous gift to the "superior"; in this case Moses brings no gift, but instead he offers himself to suffer the consequences of the people's wrongdoing--to be cut off from God.' Basically, what Moses is suggesting to God is, "Either you, God, nāsā ${ }^{2}$ the wrongs of the people [i.e. forgive them] or let me nāsāj them and suffer the consequences [i.e. die]."2 The effect for the people would be the same. In both cases they would be released from the immediate consequences of their attitude and actions, but only God's act of nāsā’ would provide them with real forgiveness.

These two passages both show that the process of "kpr" does not necessarily require blood sacrifices to be effective, even though that was generally the rule. ${ }^{3}$ In

${ }^{1}$ Exod $32: 32$.

${ }^{2} \mathrm{Cf}$. also chap. 5 above where it is pointed out that to nāsa $\bar{a}^{2}$ wrongdoings will ultimately lead to the death of the bearer.

${ }^{3}$ On the general meaning of $k p r$ see Bernd Janowski, Sühne als Heilsgeschehen. Even though in most cases $k p r$ involved blood sacrifices, there were several instances where that was not so. But, all kpr processes demanded something of value to be presented; $c f$. Gudmundur Olafsson, "The Use of Kaphar in the Pentateuch" (Unpublished term paper, Andrews University, 1983). 
one sense, however, it can be said that in the Exodus passage there was a sacrifice involved, since Moses offered himself in an effort to save the people. His was a symbolic/real offer of life similar to the sacrifices in the sanctuary. It was substitution in line with Lev 17:11, where one life is substituted for another--one obtains life by means of another's death. In his response God promised to continue to lead the people by his angel, even though the people had to suffer the immediate consequences of their wrong actions.

Freedman and willoughby have pointed out in this connection that "Gott zwar nicht die Konzequenzen für den Sünder aufhebt, sie aber auch nicht prolongiert. Er vergibt, aber verstöBt nicht." 2 This is so because the nāśa ${ }^{\supset}$-process is not primarily concerned with individual wrongdoings; it involves, rather, a general attitude of patience and endurance. ${ }^{3}$ In spite of the people's wrongdoing God was willing to go with them and renew the covenant with them." This meant restoring them as his possession,' and driving out their enemies before them. ${ }^{6}$

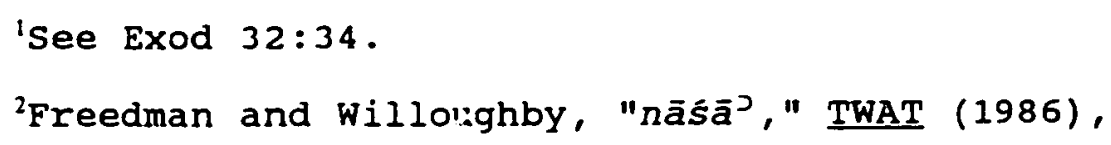
$5: 638$.

${ }^{3}$ Ibid.

'See Exod 34:10-28.

${ }^{5}$ Exod $34: 9$. 
God's nâśa $\bar{a}^{2}$-forgiveness meant acceptance of the people without necessarily approving their actions.

The third passage is found in Lev 10:17 in the context of the sanctuary service. Some of the sinofferings were to be eaten by the priest in the holy place.' Once, when the sons of Aaron had failed to do so, Moses rebuked them saying, "He [God] gave it to you to bear away (nās $\bar{a}^{2}$ ) the guilt (câon) of the congregation, to make atonement (kpr) for them before the Lord."2 In this passage "kpr" and nāsā" are apparently synonymous. There is nothing in the context that subordinates one to the other. Násáp could also be translated "forgive" in this context These theologically distinct aspects of $n \bar{a} \bar{s} \bar{a}^{J}$ are not distinguished in Hebrew. ${ }^{3}$ Whereas "kpr" is seen as a process leading to nāśa in Gen 32 and Exod 32 , in Lev 10 they appear to be parallel or even synonymous.

\footnotetext{
${ }^{6}$ See Exod $34: 11,24$.
}

'See Lev 6:24-30. Some scholars, such as David P. wright, 133, and Jacob Milgrom "Two Kinds of Hattāt t" VT $26(1976): 333-4$, see it, however, as a payment to the priest for bearing the responsibility for performing the purgatory rites. Wright points out, though, that Milgrom apparently no longer is so sure, and eating the hațț $\bar{a}^{5} t$ may actually be a means of disposal.

${ }^{2}$ Lev $10: 17$.

${ }^{3}$ See Knierim, 52, 220. "Einmal muB der Mensch seinen het ${ }^{2}$ selbst tragen (und sterben), das andere Mal trägt Jahwe oder ein anderer Mensch den het ${ }^{\supset}$ des Menschen weg, und der Täter lebt. Im letzteren Fälle übersetzen wir herkömmlich: vergeben. Beidemal aber ist die hebräische Wendung die gleiche." 
If there is any difference at all nāśa may be seen as a process leading to "kpr." In the light of the other two passages it seems to indicate that the sequence nāsā? "kpr"/"kpr"-nāsāj at times was interchangeable. The important point for the present study is, however, the fact that nāsáa is clearly parallel with "kpr" in the process of restoration and/or forgiveness.'

$$
\text { Nāśă and sālaḥ }
$$

The terms nāśa and sālạ are placed in parallel two times in the Pentateuch: in Exod 34:7,9 and Num 14:1820. Both are in the context of Moses' mediating for the wrongdoings of the people. The former follows the making of the covenant and the latter is in the context of the people's receiving the report of the spies. As God revealed to Moses his nature, Moses "made haste to bow low toward the earth and worship" (Exod 34:8) and plead with God to forgive (sālaḥ) the iniquity and sin of the people (vs. 9). This is clearly a reference to the parallel expression in the theophany where God revealed himself as "the Lord . . . who forgives (nośê) iniquity, transgression and sin." In this passage Moses pleads with

'The three passages being considered here are often assigned to three different sources: Gen $32: 20$ (E), Exod $32: 30$ (J), and Lev 10:17 (P). In spite of that, they appear to be quite uniform, both theologically and structurally. 
God that he "forgive (sālaḥtā) our iniquity and our sin."l

The basic meaning of sālah may not be entirely clear, ${ }^{2}$ but it is usually seen as being a terminus techniclis for forgiveness, as it is only used in that sense and has only God as subject. In the present context there is no apparent difference between sālah and nās $\overline{\mathbf{e}}^{\supset}$, except that sälah seems to be a specific application of the more general nāsa $\bar{a}^{2}$ in a given situation. This becomes evident as Moses explains what he expects from God's sälaḥ: "take us as your possession (aneḥaltäna)." Moses is actually requesting God to accept the people, but acceptance is exactly one of the main concepts of nassa ${ }^{2}$ when used in interpersonal relations. ${ }^{3}$ In his response God promises to establish a covenant with the people in order to formalize the relationship between himself and the people (vss. 10-17), a fact which indicates that the náśă process involves a relationship.

The other passage in which sālaḥ and nāśă are used in parallel, Num 14:18-20, is based on the same theophany. As the people heard the report of the ten spies upon their return from Canaan they began to grumble,

\footnotetext{
${ }^{1}$ Targum onkelos and Peshitta translate both of these terms with the root šbwq in these passages.

${ }^{2}$ Cf. J. Hausmann, "ll O sālaḥ," TWAT (1986), 5:860-1.

${ }^{3}$ See chapter 6 above.
} 
wishing to abort the exodus and return to Egypt.' Thereby, they in effect rejected God's leadership and decided to elect a new leader to bring them back to the land of Egypt. By that suggestion they implied that God's plan of salvation was a total failure, as far as they were concerned. The synonymous, parallel use of nāsāj and sălah in this passage is quite significant. Because God is a forgiver of iniguity (nośē' cāwôn) ${ }^{2}$ Moses asks him to forgive the iniquity (sālạ̣ $I a^{c a}$ wôn) of the people, ${ }^{3}$ as he

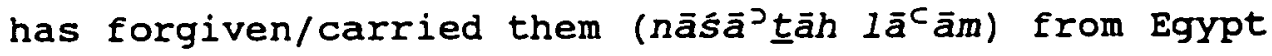
onward; ${ }^{4}$ to which God replies that he has already forgiven (sālaḥ).s

Both God's forgiving (nāsáa $\bar{a}^{2}$ ) and Moses' request for forgiveness (sālaḥ) are grounded in God's hesed which in this context sakenfeld $d^{6}$ has correctly pointed out means "faithfulness to be given expression in willingness to forgive, ability to forgive, as known from God's forgiving

'See Num $14: 1-3$.

${ }^{2} \mathrm{Num} 14: 18$.

${ }^{3} \mathrm{Num} 14: 19 \mathrm{a}$.

'Num $14: 19 \mathrm{~b}$.

${ }^{5}$ Num 14:20. Both TgN, Tgo, and Peshitta translate these terms with šbwq. The LXX uses the sequence $\alpha \phi \alpha$ เ $\rho \omega$, $\dot{\alpha} \phi \iota \eta \mu \iota, i \lambda \epsilon O \zeta \quad \dot{\epsilon} \in \nu \circ v$, and $i \lambda \in O \zeta \in i \mu \iota$. This last parallel also confirms the early translators' perception of the parallel between nāsás and sālah in this context.

${ }^{6}$ Sakenfeld, 123. Cf. Num $14: 19 b$. 
action thus far."

God's forgiveness of Israel's lack of trust has already been experienced. He has shown willingness to maintain that covenant relationship even when Israel's actions ought to have freed him from any responsibility for the people. Once he established the relationship he has maintained it.'

The fact that God has forgiven (sālạ̣) does not,

however, release the people from punishment, as some

scholars have suggested $i^{2}$ neither does it involve

forgetting, as is often popularly believed. The forgiven

people and their descendants still had to nāsāo the

consequences of their wrong actions and attitude. None of

the people involved in the rebellion were permitted to

enter the Promised Land and their children had to wait

almost forty years for their share in the promise. In

this way they had to share in the immediate consequence of

their fathers' wrongs, even though they themselves were

not guilty. The context shows that forgiveness meant

\footnotetext{
'Ibid., 124

${ }^{2}$ So Walther Eichrodt, Theology of the old Testament, 2 vols., trans. J. A. Baker (Philadelphia: Westminster Press, 1961 and 1967), 2: 453,457, where he defines forgiveness as "Jahwen remov[ing] the baneful influence of an act." Cf. also Freedman, "nāsāJ," 627,639; and G. von Rad, old Testament Theology, 1:268. Th. Raitt, "The Concept of Forgiveness in the Pre-Exilic Prophets," 297, contends that "God steps in and stops the [sinconsequence] process before it culminates. Forgiveness thus provides reprieve, healing, clemency, and life." Eugene H. Maly sees it as "refusal to seek revenge" in his article "Sin and Forgiveness in the Scriptures," in sin, Salvation, and the spirit, ed. Daniel Durken (Collegeville, MN: Liturgical Press, 1979), 45.
} 
that, in spite of the people's wrongdoing, God would not forsake them even in their suffering. He would continue to go with them and guide them on their way to the Promised Land.' The fact that they suffered the consequences of their actions did not nullify God's forgiveness, nor the other way around. The consequences were the natural outgrowth of their wrongdoings, whereas forgiveness works in spite of them.

The perceived parallelism/synonymity of nāsa ${ }^{2}$ and sälaḥ is later confirmed by Neh $9: 16,17$ which is clearly a reference to this very event.

But they, our fathers, acted arrogantly; they became stubborn and would not listen to Thy commandments. And they refused to listen, and did not remember Thy wondrous deeds which Thou hadst performed among them; so they became stubborn and appointed a leader to return to their slavery in Egypt. But Thou art a God of forgiveness ( $s^{2} l i h o t$ ), ${ }^{2}$ gracious and compassionate, slow to anger, and abounding in lovingkindness; and Thou didst not forsake them.

The entire passage in Neh 9 (especially vss. 1621) is enlightening in the context of this research. It relates the two experiences in the life of Israel under consideration here and gives an important insight into the understanding of the terms under consideration. First, the God of forgiveness (nosié $\left.\right|^{2}$ ) in Numbers and Exodus is

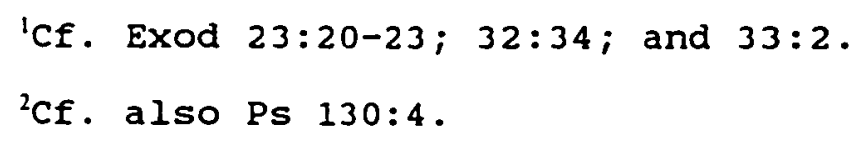


presented in Nehemiah as the God of forgiveness (s'liḥot).' Second, God's seliḥot, both in the experience recorded in Numbers 14 and in the rebellion at Sinai, is demonstrated by the fact that God did not forsake them (vss. 17,19$)$, but rather kept guiding them on their way, instructing them and providing them with their physical necessities (vss. 19-21), all of which have been shown to be included in the act of nāsá in the Pentateuch. ${ }^{2}$

\section{Theological context}

As we observe the concept of $n \bar{a} \bar{a}^{2}$-forgiveness in the Pentateuch we see that it is basically a caring atiitude which is activated when there is a breach in a relationship. Such breach or rupture is what constitutes sin. ${ }^{3}$ When that happens, a healing process of forgiveness is needed, and is mostly found in some relation to the

'Cf. also Ps 103:3.

${ }^{2}$ See chapter 4 above. Comparing these references from the Pentateuch and Nehemiah there appears to be an indication of a movement from the more general and comprehensive nāsa ${ }^{2}$ in the earlier writings to the more specific term salah for forgiveness in the later writings.

${ }^{3}$ See Robert Koch, Il Peccato nel Vecchio Testamento, (Rome: Edizioni Paoline, 1973), 14. Moshe Weinfeld, "ת' berft," TDOT (1975), 2:276, points out that in case of a broken covenant, the document must be destroyed. In Babylonian legal literature the cancelling of a contract is to "break the tablet."

'Cf. Moses' action following the golden calf incident as he pleads with God that he nāsá the wrongdoing of the people (Exod 32:32). 
covenant. In fact, there is a close interrelationship between these two concepts, forgiveness and covenant. Nevertheless, there were no nāsā’ texts found explicitly within a covenant context in the Pentateuch, i.e., because there is a covenant therefore there is forgiveness. On the other hand, the covenant is twice related to the concept of nāśă'forgiveness. As God was about to introduce his covenant to the people he referred to his actions towards them as those of an eagle who carried (nās $\bar{a}^{2}$ ) them to himself (Exod 19:4); an action which Moses later equates with forgiveness (Num 14:19). On that basis God offers the people to enter into a covenant relationship with him (Exod 19:5-8). Similarly, when the covenant had been broken following the golden calf incident, Moses pleads with God to forgive the people (Exod 32:32). Before the covenant is renewed God reveals himself to Moses and indicates that his forgiving (nôśe $\bar{e}^{-}$) of sins is a part of his nature (Exod 34:7). Based on that, God again offers to (re-)enter into a covenant relationship with his people (Exod $34: 10$ ).

This may suggest that the concept of nāsā? forgiveness is really foundational to that of the covenant, so even before there was a formal covenant there was forgiveness.' It is rooted in who God is, not a

${ }^{1} \mathrm{Cf}$. the experience of cain in Gen $4: 7$. 
formal arrangement. Forgiveness is thus both the basis for and also the outgrowth of the covenant.' That is why God can freely offer it even to individuals outside of that formal arrangement.

When it comes to the actual process of dealing with the sins and wrongdoings, Knierim ${ }^{2}$ has pointed out that the Hebrew language per se does not make a distinction between suffering the consequences of one's actions and forgiving them in the context af nāsāo. The only difference is found in the change of subjects. In one case man nāśa $\bar{a}^{2}$ his own wrongdoing and dies; in the other, someone else is doing the nās $\bar{a}^{\supset}$ and the wrongdoer lives. In both cases the object is the same--sins and/or wrongdoings. The latter condition is usually correctly associated with the concept of forgiveness, but it is on the basis of interpretation rather than translation.

In these passages the context indicates a process leading to a restored relationship or full acceptance, both of which are closely associated with the concept of forgiveness. By bearing ( $n \bar{a} \bar{s}^{3}$ ) the wrongs ('āwôn) of the people by substitution, the priests and Levites effected

\footnotetext{
'Moshe Weinfeld, "Berft--Covenant vs. Obligation," Biblica 56 (1975), 124, has pointed out that in the stories of David and Jonathan hesed and "love" seem to be both the preconditions of berit and also the outcome.
}

${ }^{2}$ See Knierim, 51-54. 
acceptance and atonement for the people,' which are basic elements in the nass $\bar{a}^{2}$ process. The experience of the husband bearing (nāsáa ${ }^{2}$ ) his wife's guilt, because of a wrongly cancelled vow, in Num 30, also confirms this concept. He bore (nāśă $\bar{a}^{2}$ ) her guilt (Cơônāh) (vs. 15), whereas she received forgiveness (sālaḥ) from the Lord (vs. 12$) \cdot{ }^{2}$

In some cases the nās $\bar{a}^{2}$-process does not necessarily involve acceptance, but appears to limit itself to the removal of the immediate consequences of some wrongdoing, or is at least interpreted as such. This was apparently the case with Pharaoh in Exod 10. In response to his pleading for forgiveness (nāsia $\bar{a}^{2}$ ) for his sins (hattga'tif), the plague of locusts was removed without any evidence of him ever being accepted by God or Moses. Then there are cases of acceptance without the removal of the immediate consequences. That was the experience of the children of Israel as they listened and reacted to the report by the spies in Num 14 . Because they rejected the report of the faithful spies the people were told they would not enter the Promised Land, and

'See Lev 10:17.

${ }^{2} A$ similar idea is also present in the experience of Joseph's brothers. As they pleaded for forgiveness (nass $\bar{a}^{2}$ ) for their wrongs (peśa'), Joseph assured them of his acceptance which was confirmed by his support ( “kalkēl) of them and their families. See Gen 50:15-21 and further discussion in chapter 6 above. 
their children would have to suffer for their (i.e., the parents') unfaithfulness for forty years.' The children's suffering, however, did not secure forgiveness for the parents--they were already forgiven (sālaḥ) according to Num 14:20. God had forgiven and accepted the people, but everyone still had to share in the immediate consequences of their parents' wrong actions.

Finally, there is the removal of wrongdoings from among the people, confirming an already existing acceptance. This process took place by means of the "goat for Azazel" which was appointed by a lot to transport or remove ( $\left(\bar{a} \hat{s}^{2} \bar{a}^{2}\right)$ the sins ( $\left.{ }^{c} \bar{a} w o ̂ n\right)$ from the camp into the uninhabited wasteland. ${ }^{3}$ The Azazel-process is the only account in the Pentateuch explicitly emphasizing the aspect of removal of sin and/or wrongdoing. People were already experiencing forgiveness, evidenced by the fact that whenever the atonement process took place through the year, it led to forgiveness (sālạ̣)." The nāsā’ process of sins, however, always led to the suffering and/or death

\footnotetext{
${ }^{\mathrm{t}} \mathrm{Num} 14: 33-35$.

${ }^{2}$ See Lev $16: 8$.

${ }^{3}$ Lev $16: 10,21$.

'Cf. the formula "And he [the priest] shall make atonement for $X$, and he $[X]$ shall be forgiven" which occurs some 13 times in the Pentateuch (Lev 4:20, 26, 31, $35 ; 5: 10,13,16,18 ; 6: 7 ; 19: 22 ; \operatorname{Num} 15: 25,26,28$ ).
} 
of the bearer.' There is, however, no evidence for the death of the goat for Azazel.' Therefore, it can not be seen to represent the "forgiver." 3 The other goat, on the other hand, called "the goat for the Lord," was sacrificed." It represented what God had revealed about himself in Exod $34: 6,7$ and Num 14:18, that he is the forgiver (nośé) of iniquities and transgressions, taking on himself all its consequences, including suffering and death.' Knierim shies away from making that connection, even though the evidence points that way. He probably finds it too unbelievable. "Ist Gott der Träger, dann kann allerdings kaum davon die Rede sein, daB Gott selbst dadurch--stellvertretend--2u schaden kommt." 6 But this is the great mystery and greatness of forgiveness. God

'See chapter 5 above.

${ }^{2} \mathrm{~A}$ later Jewish tradition stipulated that the goat be pushed over a ragged edge to its death, but the Bible only states that it was brought out into the wilderness. (Cf. Gladson's "The Enigma of Azazel in Leviticus 16.")

${ }^{3}$ Some scholars, as Freedman, "nāsā̃ ," TWAT, (1986), 5:637, seem to overlook that aspect, and therefore see the goat as representing the forgiving aspect of Christ's ministry.

tSee Lev 16:9.

SThat concept, however, is only implied at this stage. It is further explicated in the servant passage in Isa 53, but only fully revealed in the Gospels and other New Testament writings in statements such as, "Behold, the Lamb of God who takes away [or: forgives] the sins of the world."

${ }^{\circ} \mathrm{Knierim,} 52$. 
presents himself as the ultimate carrier of man's wrongdoings.'

God is thus the prime provider of forgiveness. But man can only enjoy its benefits if he is willing to accept and cooperate with God's leadership and guidance. That is the message of Gen $4: 7$ and Exod 23:21. In the Genesis passage God presents the availability of forgiveness/acceptance ( $\hat{s}^{e \nu} \bar{e} t$ ) to Cain if he is willing to cooperate; otherwise, he will be at the mercy of his own wrongdoings. The latter passage presents the opposite picture. If anyone rebels against God and his leadership, acceptance/forgiveness is no longer available (10 yiska ${ }^{2}$ $\left.I^{e} p i \check{s}^{C a} \underline{k} e m\right)$ for God cannot approve of rebellion.

In all of these situations nāsā’ is used to express actions and/or attitude employed for the purpose of providing relief from the burden of wrongdoing or a confirmation of its availability. Ultimately, nās̄a $\bar{a}^{-}$ forgiveness is an expression of God's hesed. Actually, it is an expression of it in action, and most commonly it leads to acceptance and/or relief from the consequences of committed wrongdoings.

\section{Social context}

There are four situations in the Pentateuch which involve individuals facing the consequences of their wrong

'Cf. Ibid., 220. 
actions, but whose cause-effect relationship is broken by means of a nāsāj-action. Two of these involve human relationships ${ }^{1}$ and two deal with the relationship between God and man. Once the entire population of two cities is involved, ${ }^{2}$ and once an individual. ${ }^{3}$ In all of these situations someone either had or was suspected of having overstepped the boundaries of acceptable behavior in some way. The process of rectifying the situation differs somewhat in these three cases. In Gen 40 the butler waits passively for the ultimate decision, which is entirely in the hands of Pharaoh who, in the end, lifts up (nāsa ${ }^{2}$ ) his head and restores him to his honorable position. On what basis he does so, we are not told, but the important fact is that it did happen.

In Gen 32 and 33, Jacob set up a detailed plan, supplemented by prayers to God, as he prepared for his encounter with Esau, whom he had frequently wronged, in the hope of finding acceptance in his sight.' In this case the wrongdoer is actively involved in preparing for the nāśa process, but the decision is again entirely in the hands of the wronged. According to Gen 33:10 Jacob found

'Gen 32 and 40:12-22.

${ }^{2}$ Gen $18: 22-32$.

${ }^{3}$ Gen $4: 7$.

4Cf. Gen $33: 8$. 
the hoped-for acceptance as he found favor in the eyes of Esau, his brother.

In Gen 18 the population of Sodom and Gomorrah had overstepped the boundaries of acceptable behavior towards God and mankind and were about to receive the just consequences of their actions. Upon hearing God's plan, Abraham appealed to God's justice' that he spare/forgive $\left(n \bar{a} \bar{s}^{2}\right.$ ) the cities if $x$ number of righteous people were present in these cities. God agreed, but unfortunately, the plan failed because the stipulated number was not achieved.: In this case the people involved were not even aware of the fact that someone was negotiating for their lives, without any demands being made on them in return. Three facts about the process of nāsāj emerge from this story: the preserving impact of even a few righteous ones on their community; God's willingness to hold back the consequences of wrongdoing; and God's care which can be mediated by a third party without any demands being made on the wrongdoer.

In Gen 4 cain realizes that his sacrifice is not

'There is no evidence that Abraham's commitment to mediation had any "atoning value sufficient for removal of guilt" as Eichrodt, 1:450, suggests. Abraham's request is entirely based on God's sense of justice and not any merits of men.

${ }^{2}$ See Gen 18:32. Only Lot, his wife, and two of his daughters were brought out, even though their righteousness was apparently quite "limited," according to Gen $19: 25,30-38$. 
acceptable to God, so he feels rejected and his countenance falls. God approaches him and opens up to him the prospect of acceptance $\left(\bar{s}^{e \nu} \bar{e} t\right)$ if he responds correctly. Cain rejects the offer, or at least ignores it, commits a heinous crime by killing his brother, and then realizes that the consequences are too heavy for him to bear $\left(n \bar{a} \hat{s}^{\top}\right){ }^{\prime}$ This short passage reveals quite clearly the basic concept of the nāss $\bar{a}^{2}$-process. When an individual does something wrong or unacceptable, the consequences are seen as a heavy burden (mass $\bar{a}^{2}$ ) which the wrongdoer must bear (nāsā’) to the bitter end. But, the wronged one may offer a relief in the form of acceptance $\left(\hat{s}^{e J} \bar{e} \underline{t}\right)$, restoring the relationship rather than permitting the wrong to destroy it. But it must be freely accepted if it is to benefit the wrongdoer. In this case, cain did not accept the offer, but severed his relationship with the Lord as he "went out from the presence of the Lord." All four stories have certain features in common while some details vary. None of them is explicitly in the context of traditional forgiveness and none of them is translated thus. But they are all associated with some wrongdoing which has created a breach between two parties of individuals. This breach needs to be bridged. That

\footnotetext{
'Gen $4: 10$.

${ }^{2}$ Gen $4: 16$.
} 
happens through a process of nass $\bar{a}^{2}$-actions. The result is in the form of favor, acceptance, or restoration, and these have been shown to be the ingredients of forgiveness, whether sālah or nāsā’

\section{God as Forgiver}

Four additional passages within the Pentateuch complete the picture of the nāsià-process, even though they are not explicitly used in the context of traditional forgiveness. They do, however, have an indirect, but significant, link with it through Num 14:19. There Moses appeals to God to forgive (sālaḥ) the people as he has carried/forgiven (nās $\bar{a}^{2}$ ) them in the past. Moses! reference is clearly to previous nās $\bar{a}^{\supset}$-experiences in the relationship between God and Israel, described in Exod 19:4; Deut 32:11; and 1:31. The first two passages speak of God who nāsả the people like an eagle, a picture which Kleinig correctly points out shows God, who did not leave the people

helpless and abandoned in a hostile world, but... 'carried' them along and 'brought' them to himself. He. . not only tolerated and led them like a shepherd with his sheep (cf. Isa 40:11; 46:3;63:9), but . . also supported and sustained them like a father with his children.'

He also draws attention to the fact that the expression "brought them to himself" is without parallel in the old

\footnotetext{
'Kleinig, "On Eagles' wing," 20.
} 
Testament. The usual expression speaks of God bringing the people to the Promised Land.' But this expression makes the process all the more personal, and God wants man to participate in that process. As he instructed Moses he told him that Moses was to nāsāj the people in his bosom like a nurse nāsāo a nursing infant, ${ }^{2}$ including providing them with their physical needs such as food. ${ }^{3}$ All of these aspects are clearly in the mind of Moses as he approached God, asking him to forgive (sālah) the people in the same way as he had $n \bar{a} \bar{s} \bar{a}^{2}$ them all the way from Egypt until then, and purposefully he seems to employ $n \bar{a} \bar{s}^{\supset}$ in his request in order to indicate what he understands forgiveness to mean.

In sumnary, the context implies an active loving, caring concern both on interpersonal level and between God and man. This can find place within the family, between a ruler and his servant, a leader towards those he is leading, or the priests as they effect forgiveness for sins. Most frequently, however, we find God providing forgiveness/acceptance to individuals, cities, or his own people (see table 22).

'Ibid.

${ }^{2}$ Num $11: 12$.

${ }^{3}$ The dialogue between God and Moses takes place in the middle of a pericope dealing with the problem of providing adequate food for the people; Num 11:4-24. 
281

TABLE 22

"FORGIVENESS" IN THE PENTATEUCH

\begin{tabular}{|c|c|c|c|}
\hline & subject & "Object" & $\begin{array}{l}\text { Effect } \\
\text { (implied) }\end{array}$ \\
\hline $\begin{array}{l}\text { Gen } 32: 20 \\
\text { Gen } 50: 17\end{array}$ & $\begin{array}{l}\text { Esau } \\
\text { Joseph }\end{array}$ & $\begin{array}{l}\text { Jacob's face } \\
\text { brothers' } \\
\text { wrongs }\end{array}$ & $\begin{array}{l}\text { acceptance } \\
\text { (sustenance) }\end{array}$ \\
\hline Gen $40: 13$ & Pharaoh & butler's face & restoration \\
\hline Num $11: 12$ & $\begin{array}{c}\text { Moses like } \\
\text { a nurse }\end{array}$ & people & $\begin{array}{l}\text { care and } \\
\text { sustenance }\end{array}$ \\
\hline $\begin{array}{c}\text { Exod } 28: 12, \\
29,30,38 \\
\text { Lev } 10: 17\end{array}$ & $\begin{array}{l}\text { Priest } \\
\text { Aaron }\end{array}$ & $\begin{array}{l}\text { people's } \\
\text { wrongs } \\
\text { people's sins }\end{array}$ & $\begin{array}{l}\text { acceptance by } \\
\text { God }\end{array}$ \\
\hline -- - & & & \\
\hline Gen $4: 7$ & God & Cain & acceptance \\
\hline Gen $18: 16$ & God & cities & $\begin{array}{l}\text { (life to } \\
\text { people) }\end{array}$ \\
\hline Exod 10:17 & God/Moses & Pharaoh & $\begin{array}{l}\text { release from } \\
\text { plague }\end{array}$ \\
\hline Exod $19: 4$ & $\begin{array}{l}\text { God like } \\
\text { an eagle }\end{array}$ & people & $\begin{array}{l}\text { (care, } \\
\text { protection, } \\
\text { sustenance) }\end{array}$ \\
\hline Exod $32: 32$ & God & people & $\begin{array}{l}\text { (life } \\
\text { quidance) }\end{array}$ \\
\hline Num $14: 19$ & God & people & $\begin{array}{l}\text { (protection } \\
\text { guidance) }\end{array}$ \\
\hline Deut $1: 31$ & God & people & $\begin{array}{l}\text { care, } \\
\text { protection }\end{array}$ \\
\hline Deut $32: 11$ & $\begin{array}{l}\text { God like } \\
\text { an eagle }\end{array}$ & people & $\begin{array}{l}\text { care, } \\
\text { protection }\end{array}$ \\
\hline $\begin{array}{l}\text { Exod } 34: 7 \\
\text { Num } 14: 18\end{array}$ & $\begin{array}{l}\text { God } \\
\text { God }\end{array}$ & $\begin{array}{l}\text { sins of people } \\
\text { sins of people }\end{array}$ & $\begin{array}{c}\text { (acceptance) } \\
\text { (protection } \\
\text { guidance) }\end{array}$ \\
\hline [Exod 23:21 & $\begin{array}{c}\text { Angel of } \\
\text { God }\end{array}$ & $\begin{array}{l}\text { wrongs of } \\
\text { people }\end{array}$ & $\begin{array}{c}\text { no forgive- } \\
\text { ness] }\end{array}$ \\
\hline
\end{tabular}




\section{other Parallels}

Besides these clear indicators of the forgiveness aspect of nāsa within the Pentateuch, supporting parallels also are found outside that corpus. Most of the passages are in the form of requests by individuals to God to forgive their wrongdoings. The basis for forgiveness is the same as in the Pentateuch: God forgives (nāsāj) sälah) iniquity and passes over the rebellious acts of the remnant of his possession forever, and he does so because he delights in unchanging love (hesed) and will not retain anger forever.'

The same concept is also found in Ps 99:8: "Oh Lord our God, Thou didst answer them [i.e., Moses and Aaron]; Thou wast a forgiving God ( ${ }^{2} \bar{e} I$ nos $\left.\bar{e}^{D}\right)$ to them, and yet an avenger of their evil deeds." This is basically a summary statement of the events described in Num 14 . God's forgiving nature forms the basis for his answering Moses' requests, but at the same time it is clearly stated that this forgiveness does not mean guiltlessness or a declaration of innocence. God forgave, but he also punished. But even in the punishment he did not leave his people. Again, in referring to the Exodus experience the prophet Isaiah bases his request on God's hesed. For he said, "Surely, they are my people. . . so he

'Mic 7:18. See also Neh 9:17; Ps $86: 15 ; 103: 8$; $145: 8$; Joel $2: 13$; and Jonah $4: 2$. 
283

became their Savior. In all their affliction He was afflicted, And the angel of $\mathrm{His}$ presence saved them; in His love and in His mercy He redeemed them; and He lifted them (waynatt'lemm) and carried them (waynas $\xi^{\mathcal{D}} \overline{\mathrm{e} m}$ ) all the days of old.'

This passage combines several Pentateuchal nāsāo images: the angel of God's presence whom God sent before his people in order to guide them on their way. ${ }^{2}$ This angel, as YHWH's representative, ${ }^{3}$ stayed with the people all through the wilderness wandering and carried them like a father, a nurse, 5 and an eagle ${ }^{6}$ all the way from Egypt onward. 7 That is why the Psalmist could also cry to God, "Save Thy people, bless Thine inheritance; be their Shepherd also and carry (naśs $\bar{s}^{e j} \bar{e} m$ ) them forever." In that process God also participated in their suffering and afflictions as is implied in the expression "God [is a] forgiver (nosié $\bar{e}^{2}$ ) of iniquity, transgression and sin." This did not only involve physical hardships but also the bearing of the sins of the people as was symbolically

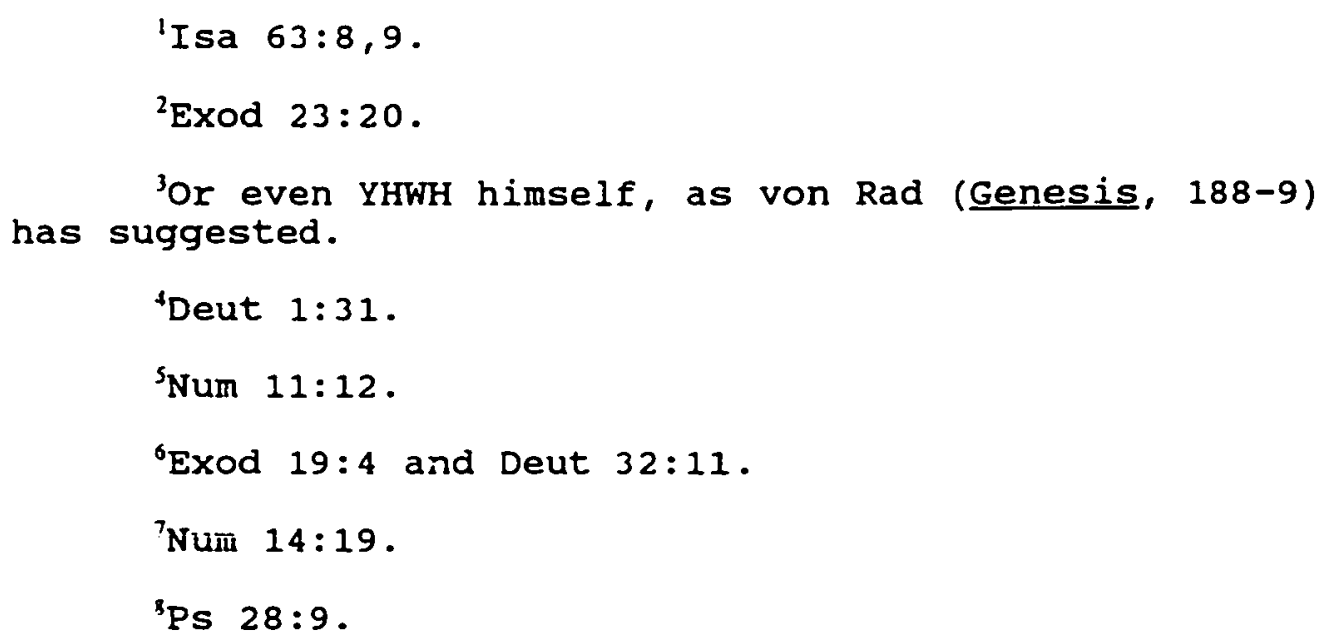


transacted in the sanctuary and ultimately led to the death of the "goat for the Lord" on the Day of Atonement. Later, that picture is picked up by Isaiah in the image of the suffering servant: "Surely our griefs He Himself bore (nāśa $\left.\bar{a}^{2}\right)$, and our sorrows He carried (sābal) . . He Himself bore ( $\left(\bar{a} \bar{s} a^{2}\right.$ ) the sins of many and interceded for the transgressors"' and ultimately died for them.'

But in order to benefit from this provision the people had to choose to accept and cooperate. If they chose to forsake the Lord and serve foreign gods, God would "not forgive your transgressions or your sins," nor would he forgive his people when they had left him. ${ }^{4}$ When the land is filled with idols which the people worship and they rely on material things, there is no forgiveness available." This is in line with the warning issued in the Pentateuch that the angel of the Lord would not forgive the people if they turned their backs in rebellion against him. ${ }^{6}$

Most of the remaining non-Pentateuchal nāśā'-

'Isa $53: 4,12$.

${ }^{2}$ Isa $53: 8,9$.

${ }^{3} \mathrm{Josh} 24: 19$.

${ }^{4}$ Hos $1: 6$.

${ }^{5}$ Isa $2: 6-9$.

${ }^{6}$ Exod $23: 21$. 
passages are in poetry and in the form of prayers for forgiveness. Hosea cries out, "Take words with you and return to the Lord, Say to Him, Take away [or: forgive] (tiśsa $\bar{a}^{2}$ ) all iniquity and receive us graciously."l

Forgiveness is here presented as gracious acceptance which will result in caring salvific actions through which the people will be healed $(r \bar{a} p \bar{a})$ in love. ${ }^{2}$ The same idea is also expressed by Isaiah, where the concept of forgiveness (nāsa $\bar{a}^{2}$ ) of iniquities is associated with healing, so no one will say "I aln sick." In Ps 103:3 similar healing is associated with sālaḥ: "Who pardons (sālaḥ) all your iniquities; who heals ( $\left.r \bar{a} p \bar{a}^{2}\right)$ all your diseases." Iniquity is presented as a disease that needs to be healed. The same idea is also found in Ps 25:16-18:

Turn to me and be gracious to me, For I am lonely and afflicted;

The troubles of my heart are enlarged; Bringy me out of my distress.

Look upon my affliction and my trouble, And forgive ( $w^{e} \bar{s}^{\bar{a}}$ ) all my sins.

sin is seen as affliction, trouble, distress, and loneliness from which the Psalmist pleads for forgiveness, involving graciousness and awareness that God is turned towards him (signifying acceptance and favor).' Another

${ }^{1}$ Hos $14: 2$.

${ }^{2} \mathrm{Cf}$. vss. $4-5$.

${ }^{3}$ Isa $33: 24$.

${ }^{4} \mathrm{Cf}$. chap. 6 above. 
Psalm speaks of the happy feeling resulting from experienced forgiveness "whose sins are covered ( $\Omega^{e} \xi$ ay pešac)."l Ringgren has pointed out that covering does not mean "hiding" or "stoving away" but rather the nonactivation of the consequences of the wrongdoing. ${ }^{3}$ when an individual brings his wrongs to God, he is willing to

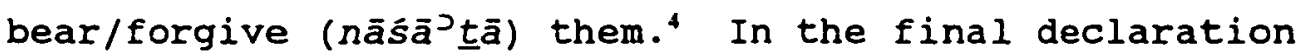

all the key concepts of forgiveness come together:

o Lord, Thou didst show favor to Thy land Thou didst restore the fortunes of Jacob.

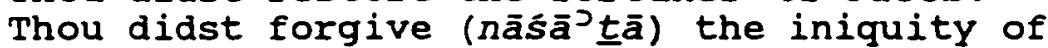
thy people; Thou didst cover (kissițā) all their sin. Thou didst withdraw all Thy fury; Thou didst turn away from Thy burning anger ${ }^{6}$

The conceptual chiastic structure places "forgive" and "cover" in a central parallelism which is then further expanded in the "arms" of the chiasm. God's forgiveness

\footnotetext{
${ }^{1}$ Ps $32: 1$.

${ }^{2}$ Ringgren, "JOāsāh," TWAT, (1984), 4:276. In Neh 4:57 kisseh is used parallel with măhāh "wipe out," "destroy."

${ }^{3} \mathrm{Cf}$. Ps $32: 2$.

${ }^{4}$ Ps $32: 5$.

scommentators point out the ambiguity of this term. The kethib is šbut "restoration," "returning," whereas the qere reads s'bit "captivity." Michael D. Goulder, The Psalms of the Sons of Korah, JSOT Supplement Series 20 (Sheffield: JSOT Press, 1982), 99-102, argues for "fortunes" as more general and contextually more applicable.

${ }^{6}$ Ps $85: 1-3$.
} 
is evidenced in his favor to the land, turning away his anger and fury as he restores the fortunes of Jacob which eventually will be evidenced in the experience of salvation.' The key concepts of this passage, "favor," and "restoration" were also associated with nāsa" forgiveness in the Pentateuch, as was pointed out above. Throughout the old Testament there is thus no apparent

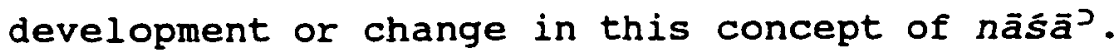

Listen to Me, O house of Jacob, All the remnant of the house of Israel, You who have been borne (hacamusim) by Me from birth, and have been carried (hann'su ${ }^{2} \mathrm{Im}$ ) from the womb; Even to your old age, I shall be the same, And even to your graying years I shall bear (Jesbol) you! I have done it, and I shall carry ('éśsä) you; And I shall bear ('esbol) you, and I shall deliver you. ${ }^{2}$

This passage clearly has the overtones of caring concern for the well-being of the individual, which eventually leads to deliverance, an idea which was also quite evident in the Pentateuchal usage of nāsa ${ }^{2}$.

\section{Summary}

The evidence thus indicates that "forgiveness" is not merely an "attached" secondary meaning of nāsā’. It is definitely just as much within its semantic range as "carry," "bear," and "lift." Parallel usage of nāśā with "accepted" terms for forgiveness (i.e., sālạ̣ and kpr),

\footnotetext{
'See vss. 4-7.

${ }^{2}$ Isa $46: 3,4$.
} 
together with its use in contexts of reconciliation, both within and outside of the cultus, confirm this.

Additional support is also found outside the Pentateuchal corpus. It is just a matter of contextual interpretation to identify the differences.

Frequently, the authors appear deliberately to use the wide-ranged, flexible term $n \bar{a} s \bar{a}^{\supset}$ rather than the apparently more restricted salah in order to emphasize the broadness and "down-to-earth-ness" of the concept and also to draw the attention to the "schicksalwirkende Tatsphäre"l of nāsā̃ , which includes the whole range from the wrongdoer's suffering the consequences of his actions ${ }^{2}$ to the beneficial effects for him from someone else's substituting for him as the sin-bearer. 3 Ultimately, the bearer of the wrongs (the forgiver) will bear the consequences of wrongdoing: suffering, separation, and even death. In the same way as any $\sin$ is seen as affecting man's relationship with God," so is the process of forgiveness also ultimately rooted in him.

The fact that a common, every day term is used

${ }^{\prime} \mathrm{K}$. Koch, quoted in Knierim, $74,89$.

${ }^{2}$ See chapter 5 above.

${ }^{3}$ See chapter 6 above.

tCf. Joseph's experience in Gen 39:9.

${ }^{5} \mathrm{Cf}$. the context of the theophanies of Exod 34 and Num 14 . 
indicates the attempt to make the concept understandable and relevant to common human beings, all of whom have intimate knowledge of what burdens are, and have experienced the relief of having them removed and "carried" by someone who cares. Nāsa’-forgiveness is not a static, legal declaration of innocence. Rather, it is concerned with ongoing relationships, acceptance, and an attitude of active care for the individual's well-being and needs. This aspect is reflected in references to God's parental care for his people in connection with the concept of forgiveness.' In its broadest sense it embraces God's acceptance of and caring concern for the human race, not because of who man is or what he has accomplished, but because of who God is. And he makes this forgiveness available to all, even before or without repentance, but mankind can only benefit from it through submission and cooperative participation. 6 above.

${ }^{1}$ For a further discussion of this aspect see chapter 


\section{SUMMARY AND CONCLUSIONS}

This investigative journey was initiated by a desire to understand more fully the Biblical concept of forgiveness, especially as it relates to the common Hebrew root nāsáa $\bar{a}^{2}$. Ideally, it should have covered all of the old Testament, but practical considerations seemed to justify limiting the research to the Pentateuch. It was found that the Pentateuch presented a representative use of the term,' had the heaviest concentration of the root, or .75 per printed page, ${ }^{2}$ and also the highest ratio of metaphoric usages or 37.2 percent of the total, ${ }^{3}$ within which the concept of forgiveness is most likely to be found.

The use of the root nāsáa in some representative cognate languages was surveyed and classified as to its meanings and contexts to form a basis for a more detailed study of the Biblical usage. The purpose was to determine (1) whether nāśa had a basic, universal meaning; (2) if

'Some 25 percent of the total occurrences in the OT. ${ }^{2}$ See table 2, above.

${ }^{3}$ see table 8 , above. 
the concept of forgiveness was really within its semantic range, and (3) what the use of the root näsa might reveal about the Biblical concept of forgiveness.

Looking back at the evidence presented it is first noticed in chapter 1 that, generally speaking, lexicographers and theologians seem to agree on the basic meaning of the root nāsa as "lift," "carry," or "take," in that order.' The idea of forgiveness is usually based on the derived meaning of "remove," thus implying that it is seen merely as a matter of legal logistics: a removal of some more or less "concrete" burden of guilt or its consequences, away from the wrongdoer. One lexicographer, Holladay, also saw some uses of nāsāa ro’ ${ }^{\supset}$ as indicating pardon, and a few have noticed the concept of "caring" as being a part of nāsià , but no one has undertaken to explain the full significance of the use of this term for forgiveness. ${ }^{2}$ That lack justified the present study. Chapter 2 was devoted to the scudy of cognate languages most closely associated with Hebrew: Aramaic, Akkadian, and Ugaritic. It revealed that the usage of nāśs $\bar{a}^{2}$ could be classified under three main headings: "transport," "support," and "utilization." Aramaic and

'HAL, however, places "carry" first. See chapter 1.

${ }^{2}$ David N. Freedman comes closest as he hints at the significance of nāsáj as it relates to the concept of forgiveness in a couple of his writings. 
Akkadian use the root also in interpersonal relations, and in Akkadian the semantic range extends to include caring concern for someone in need. Akkadian also uses it in the process of dealing with wrongdoings, either for tempering the consequences or removing the wrong.

A survey of the Biblical data in chapter 3 revealed close affinity with the cognate languages both as to the usage and meanings of the root nāsáz. A brief survey of the nominal forms, however, added nothing new to the research except that most of them tend to confirm the concreteness of the root.

The verbal root is used almost exclusively in the Qal, or 598 times out of 654 occurrences. It is used both literally and metaphorically in all types of texts: narratives, legal texts, and poetry, and distributed fairly evenly throughout the OT, with no apparent indication of any significant development or change related to time, authorship or type of literature. The ratio of literal use is highest in the Early prophets, 71.2 percent, whereas the Pentateuch has 24.8 percent, with the old Testament average of 34.7 percent. As to the metaphoric usage, the Pentateuch has the highest ratio with 55 percent, while the old Testament average is 40.4 percent.

Man is the most frequent subject, or in 75.1 percent of the cases, with God or divine beings coming 
second with 13 percent. This indicates that nāsa $\bar{a}^{2}$ is basically a "human" term in contrast to sälạ, which only has God as subject. Morphological survey failed to reveal anything that might clarify or distinguish between the various meanings of the root. The same can also be said about syntactical studies. It is only when it comes to synonyms, parallels, sequels, and semantic contexts that the different meanings emerge.

In general, the Biblical usage appears to be closest to the Akkadian, which was also the cradle of the Hebrew culture. No evidence was found of any homonymous roots, but the data zevealed rather a neutral and flexible root with definite concrete connotations which is then "shaped" and "honed" by the immediate context.

A closer look at the semantic scope of näsā in the Pentateuchal corpus in chapter 4 indicated the presence of the same three basic concepts of nāśa which were found in the cognate languages. First, the idea of "transport," involving a movement from one place or position to another. That concept is brought olit in forty-two instances, or in 24.8 percent of the Pentateuchal occurrences. It is clearly indicated by the use of prepositions of movement or direction, morphs or parallel expressions which signify movement, or by the context. Second is the idea of "sustained support" or the ability to hold, contain, or maintain. That meaning is 
found fourteen times, or in 8.3 percent of the cases. The distinction between these meanings is, however, neither based on morphology per se nor syntax, but rather on the context. The last of the general meanings is that of "utilization" of certain body parts/functions (i.e., eyes, hands, feet, head or voice), or weapons and words. This usage is found fifty-one times in the Pentateuch, which is 30.2 percent of the total. Most scholars tend to take the expression in its literal sense of lifting or taking, and appear to overlook the idea of utilization, or fail to see it as an expression of ingression, or an initiation of an action.' Practically all the expressions in this last category were followed by a sequel indicating the purpose of the nāśa ${ }^{2}$-action.

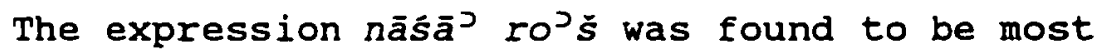
ambiguous. In places it was clearly used in its literal sense, meaning "to raise one's head," but in others it was used idiomatically for "head-counting" or census-taking. In still other instances it is used to indicate a process of restoration of someone who has "fallen from grace." Chapter 5 looked at the use of nāsā' in the context of wrongdoings. It became clear that wrongdoings, in general, are seen as concrete burdens which must be carried. In nineteen passages nāśa $\bar{a}^{\supset}$ is used in the

\footnotetext{
'Similar to ingressive aorist in Greek.
} 
context of the subject's own wrongdoings, and in eighteen it refers to wrongdoings of someone else. In all of these the emphasis is on the aspect of "carrying" in the sphere of supporting or enduring rather than that of transport or removal. In the former group, nâsáa indicates that the wrongdoer must bear the guilt and/or suffer the consequences, which in most cases were death; whereas in the latter group, nāsia at times indicates forgiveness. Nâsāj with wrongdoings of others is mostly found in cultic contexts, or in fourteen out of eighteen cases. In thirteen of these, man is the subject: priests and Levites in eight,' with other persons in five. ${ }^{2}$ The usage within the cultus strongly indicates substitution. Two texts state explicitly that one person carried someone else's wrongs: once a husband for his wife (Num 30:15) and once the Levites for the people (Num 18:23). Other passages strongly support that concept without stating it explicitly. Instead, it is indicated by means of various symbols, including certain items of clothing, or by the priest's symbolically eating a portion of certain offerings. Nāsāa is never translated as "forgiveness" in any of these texts, even though the concept is clearly present by implication. $10: 17$.

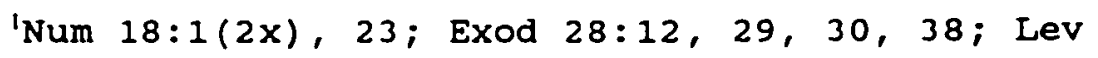

${ }^{2}$ Gen $50: 17(2 x) ;$ Exod 10:17; Num $14: 33 ; 30: 15$. 
In the non-cultic contexts three passages are in the form of requests and one is a statement. One is a request for the removal of the consequences of wrongdoing (Exod 10:17), two plead for an assurance that a former wrongdoing will not be allowed to affect present relationship (Gen 50:17). Finally, one deals with individuals who share the consequences of the wrong action of others (Num 14:33). A positive response to the requests in the first three passages is seen as forgiveness, whereas the last involves sharing the consequences.

Even though animals played a large role in the sanctuary services, there is only one passage which explicitly involved an animal in the nāśa $\bar{a}^{2}$-process of wrongdoings. It was the goat for Azazel on the Day of Atonement in Lev 16:22. In spite of various opinions as to the identity of this goat, it is clear from the context that it was never seen as a sacrifice. Its only function was one of transport or removal of all the "accumulated" sins from the sanctuary, away from the people. This is the only Pentateuchal text which explicitly speaks of the aspect of removal of wrongdoings in the nāsis $\bar{a}^{2}$-process.

In the last four passages related to wrongdoings of others, God or divine beings are the subject. They present three different aspects of the nāśā'process. First, there is a declaration about nāśă 
being a part of God's nature (Exod $34: 6,7$; Num 14:18); the second is a plea for forgiveness, based on that conviction (Num 14:19); and finally, there is a warning against presumption in light of that fact (Exod 23:21). All of these texts are generally seen as presenting forgiveness.

Three important issues also emerge from these passages. First, nās $\bar{a}^{\supset}$-turgiveness of sins involves suffering their consequences. This implies that God suffers as he forgives, however preposterous that may sound to some. Second, if the wrongdoer rejects God's forgiveness by his actions, it will not be forced on him. He will have to bear his own wrongdoings. Finally, nāsā?forgiveness does not mean a declaration of innocence (Exod 34:7; Num 14:18a). The wrongdoer is still guilty of his wrongdoing, but the difference is that the forgiver no longer holds the wrongs against the wrongdoer or permits them to come between them and adversely affect their relationship.

In chapter 6 we moved from the more impersonal aspect of nāśa to its use in interpersonal relations, which is found in twenty-two passages. In this context also we find both literal and metaphoric uses. The literal usage covered in chapter 4 forms the basis for the metaphoric uses dealt with in this chapter. In the same way as a father or a nurse carry (nās $\bar{a}^{2}$ ) their nursing young and provide them with protection, loving care, 
nourishment, and meet all their needs, so God has carried (nās $\overline{\mathbf{a}}^{2}$ ) his people through the Exodus experience and provided for all their needs because of his caring concern for them.' Moses appeals to this well-known fact as he pleads with God to forgive the people once more following their rejection of the report from the faithful spies. It is then used as an illustration of what nās $\bar{a}^{\supset}$-forgiveness really means ${ }^{2}--a$ caring concern for someone in need. The need may be physical--food, water, healing, protection--or spiritual, such as sin or guilt. Both are included. God in his mercy provides both, and he wants human beings to join him in the process. ${ }^{3}$

When you may suffer guilt as a consequence of your wrongdoings you tend to be downcast. When you are "cleared" you can freely look up. That metaphor of rejection and acceptance is used eight times in the

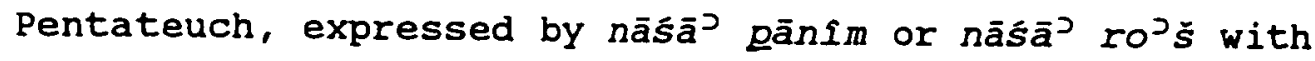
both God and man as subjects. A lifted-up face or head means acceptance, approval, or favorable attitude towards someone. Whether the subject lifts his face toward the object or lifts the face/head of the object upwards

\footnotetext{
'Exod 19:4; Deut 1:31; 32:10, 11.

${ }^{2}$ See Num $14: 19$.

${ }^{3}$ Num $11: 12-17$.

tNum 6:24,25; Deut 10:17; 28:50.
} 
toward himself' the effect is the same. Both actions signify favor and acceptance. In the same way a "place" may also be lifted up, thus becoming the object of some favor.? This favorable attitude may be mediated by a concerned "bystander," as in the case of Abraham who negotiated with God about the cities of the plain without their knowledge or any known effort on their part. God responded by showing his willingness to grant them favor. Sometimes God even takes the initiative to make that attitude available to individuals in need, as in the case of Cain (Gen 4:7). He offered Cain acceptance, but he did not force him to accept it. Human beings are given a free choice to accept its conditions or to reject them.

In chapter 7 we finally looked at three basic arguments which corroborate the fact that the concept of forgiveness is clearly within the semantic range of nāsa $\bar{a}^{\supset}$. First, the root $n \bar{a} \bar{s}^{\supset}$ is used in parallel with generally "accepted" terms for forgiveness, such as kpr and sālaḥ. There are even indications that the author(s) deliberately used the ambiguous term nāśā rather than the more specific ones in order to emphasize the broadness and relational aspect of forgiveness. Second, it is used in theological contexts where sin is being dealt with and

\footnotetext{
'Gen 19:21; 32:21; Lev 19:15(2x).

${ }^{2}$ Gen $18: 24,26$.
} 
removed from the relational sphere of God and man. The attitude of forgiveness is a part of God's nature and thus precedes the formal covenant, but is also an integral part of it. Ultimately, God himself is presented as the one who nāsā' man's wrongdoings, taking on himself all its consequences, even death, so that man may live in his presence. Finally, nāsáa is used in certain social contexts where an attitude/action of restoration and/or reconciliation is called for.

A further clarification of the "contents" of nāśāj-forgiveness was found in the fact that in Num 14:19 Moses requests the Lord to forgive (sālah) his people as he has forgiven/carried (nāśa $\bar{a}^{2}$ ) them in the past. Contextually, this meant (1) caring for them and teaching them like an eagle cares for and teaches her young (Exod 19:4; Deut 32:11), (2) protecting them and providing for their needs like a father (Deut $1: 31$ ) or a nurse (cf. Num 11:12), (3) treating them as friends in spite of their stiffnecked attitude (cf. Exod 23:23-30), and (4) even preventing them from being destroyed by their own, often foolish, actions as evidenced during the Exodus experience. This is, however, not unique in the Pentateuch; it is one of the basic teachings of the various parts of the old Testament, be it the Prophets (cf. for instance, Isa $46: 3,4 ;$ and $63: 8,9$ ), the Psalms (cf. Ps 85:1-3), or the writings (e.g., Neh 9:16-25). 
The findings of this study have inevitably raised several questions and issues that invite further investigation. Hopefully, additional studies will clarify issues such as, how this concept of forgiveness affects the traditional concepts of justification and sanctification; if nāśa ${ }^{2}$-forgiveness is different from one expressed by sālạ̣, $k p r$ or any other term; or how this concept affects the ethics of forgiveness in general. In order to answer these and similar questions, a study needs to survey all of the old Testament and include all direct and indirect references to the restoration of a broken relationship. It is the conviction of this researcher that such a study will show that forgiveness is not only a major New Testament theme, but it is also a key theme in old Testament theology.

However, this research has shown that the concept of forgiveness needs to be expanded. Some may only see forgiveness as the removal of guilt and the barrier that exists between God and man.' But it is much more. ${ }^{2}$ In non-cultic texts forgiveness is found in family relations between brothers, ${ }^{3}$ as the wrongdoers are being accepted by the one they had wronged. It is also found as a ruler

\footnotetext{
'Freedman and Willoughby, "nāśā’," TWAT (1986), $5: 638,639$.

${ }^{2}$ See table 22 on page 281.

${ }^{3}$ Gen $32: 20 ; 50: 17$.
} 
restores a suspected servant,' and when God commands Moses, as the leader of his people, to care for them. ${ }^{2}$ Ultimately, we find God offering forgiveness/ acceptance to an individual--even before he committed a crime--at the beginning of human history. ${ }^{3}$ Later he shows his willingness to extend it to wicked cities, ' and he responds favorably to a request by an enemy king.5 Most often, however, God extends his forgiving to his covenant people. 6

In cultic contexts we find both Aaron and the priests effecting forgiveness for the people's sins, ${ }^{7}$ and ultimately God, whose nature it is to forgive sins." In fact, all forgiveness--apart from Pharaoh's restoration of his servant'--is associated with God. ${ }^{10}$ Human beings

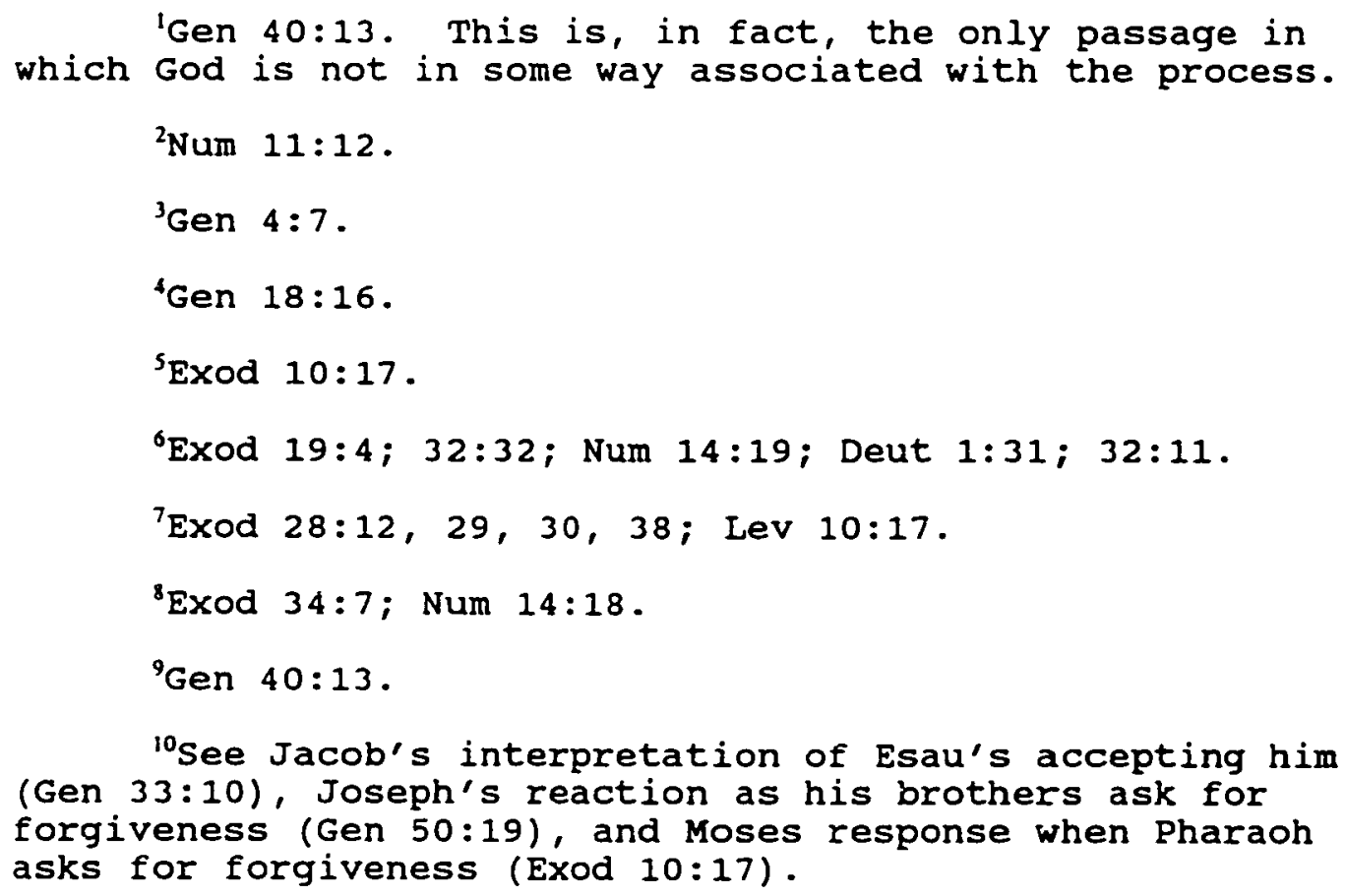


participate with God in the process.

Therefore, forgiveness should not be restricted to being a legal declaration of non-guilt, a passing over or a cancellation of debt or guilt, a wiping out or taking away of a record of guilt, or an undeserved response to repentance and confession. But it includes the sharing or bearing the burdens of those in need, whether they are physical or spiritual. Rather than being a single act, nāśălforgiveness is an attitude; rather than being a simple declaration of innocence, it involves a continued personal interest in those you care for, in spite of their wrongdoings.

It is tempting to see this image of carrying (nāśa $\bar{a}^{2}$ ) being drawn from the Hebrew people's own daily experience who spent their "infancy" as a nation in slavery, constantly carrying heavy burdens. All must carry their own burdens. That process frequently led to the death of the carriers unless someone offered to take/ carry it for them. That imagery is then transferred to the context of wrongdoing in the old Testament. Any wrongdoing is seen as a burden that must be carried to its bitter end--death. Sometimes, someone might offer to take the burden and carry it for the wrongdoers, in which case they were "released" from their burdens. They were free-forgiven. The substitute carrier, however, took the consequences. In the Hebrew language there is no 
distinction made between these two actions. The former action causes pain and suffering for the wrongdoercarrier, whereas the latter brings relief to the wrongdoer. Only the context makes the distinction. The latter action is associated with forgiveness. This ambiguity of the nāśa $\bar{a}^{2}$-process, which is lost in translation, leads to an unawareness of the suffering to the "forgiver"-carrier for taking on the burden of guilt.

In cultic contexts the nāsāa $\bar{a}^{2}$-process was acted out by means of a visual aid in the sanctuary service, as both the priests and the Levites substituted for the wrongdoer and symbolically removed and carried (nāśă $\bar{a}^{J}$ his sinburden "in" and "on" their bodies into the sanctuary, bringing experiential forgiveness to the wrongdoer. Once a year "the accounts were closed" and the accumulation of forgiven sins of the people were "loaded" on the "goat for Azazel" who transported (nāśā') them away from the people, out into the wilderness, away from the camp. This is, in fact, the only indication in tha naśä'-process of wrongs explicitly involving a removal, reinforced by the use of two morphs of movement: $\nu_{e l}$ and the directional $-\bar{a} h$. The nāsás-process is thus not primarily a removal of $\sin$, even though that may be its ultimate goal.

$$
\text { In non-cultic contexts the nāsa } \bar{a}^{2} \text {-process took }
$$

place as someone--either the wronged or someone else--took (nāśs') upon himself the wrongs of another, or acted as an 
intermediary between the wrongdoer and God. The effect on the wrongdoer was the same: an experience of relief or forgiveness, a release from the burden of guilt which might also include a release from punishment. It is not explicitly stated what happened to the one who took on himself the burden, but the logical indication is that he ultimately suffered the consequences that were due the wrongdoer, because he, in fact, became his substitute. Forgiveness did not, however, necessarily remove all aspects of the consequences from the wrongdoer. Cause-and-effect relationships are not necessarily broken by forgiveness. Suffering the consequences of one's wrong actions is not necessarily an evidence of the absence of forgiveness. Neither is the immediate absence of consequences necessarily an evidence of forgiveness. Forgiveness involves a personal relationship, whereas consequences are impersonal. In this process of dealing with wrongdoing, uninvolved bystanders might be affected to some extent. They might suffer some of the consequences, not because they did something wrong, but because they happened to be among those who did. In contrast to the popular idea which sees forgiveness only, or at least primarily, as a legal declaration of innocence, based on repentance and forgetting, leading to the removal of guilt and punishment, the Pentateuch pictures nās $\bar{a}^{\supset}$-forgiveness as 
not satisfied with mere toleration. It involves acceptance of the individual, restoring him to a position of full honor, not because of his worthiness but because of who the forgiver is. It does not presuppose repentance, nor necessarily lead to the removal of punishment, but expects submission. In Num 14:20 God states that he has forgiven the people, but they will still suffer the immediate consequences of their action, even forty years later. However, God continues to be with them in their suffering and care for them as before. Their wrongdoing led to suffering, but due to God's mercy their relationship with him was not severed. That is what nāśa'-forgiveness indicates: a caring concern for the wrongdoer in spite of knowing and remembering all about him. Experientially, that knowledge/remembrance becomes inactive. It is not permitted to affect the relationship, as long as the wrongdoer chooses to remain in that loving relationship.

$$
\text { Nās } \overline{\mathbf{a}} \overline{\mathbf{D}}^{\supset} \text {-forgiveness is ultimately an expression of }
$$

God's loving attitude toward human beings, evidenced throughout salvation history for the purpose of restoring them to a position of acceptance before God, in spite of knowing all about their shortcomings. This involves showing caring concern for them in their struggle throughout life, offering to take on the burden of $\sin$ and guilt, thus releasing the wrongdoer, and ultimately 
suffering its cruel consequences, death, thereby removing it from their sphere of existence, so they may again be free to live their lives in perfect peace before God and among each other. It is really the story of redemption in action.

on the personal level nāśa $\bar{a}^{2}$-forgiveness means that human beings cooperate with God in this process, and show the same caring concern for their neighbors. Thereby they will reflect the true image of God to their environment. Rather than attempting to forget the wrongs of the wrongdoers, or passively sending them off with a mere legal declaration of forgiveness, the wronged will nāsás their neighbors by not allowing the knowledge of their wrongs to get in the way of establishing and maintaining a caring relationship. The forgiver will also actively endeavour to restore the wrongdoer to a position of full acceptance in society. This is not done by a single act. It involves an ongoing attitude in line with Jesus' instruction to peter about being ready to forgive seventy times seven. Only then and thus will human beings truly nāśă their fellow human and become bringers of peace.

Bear one another's burdens and thus fulfill the law of christ.'

${ }^{1}$ Gal $6: 2$. 
APPENDICES

Reproduced with permission of the copyright owner. Further reproduction prohibited without permission. 
Append ix A

GENERAL DISTRIBUTION OF NS' IN THE OT

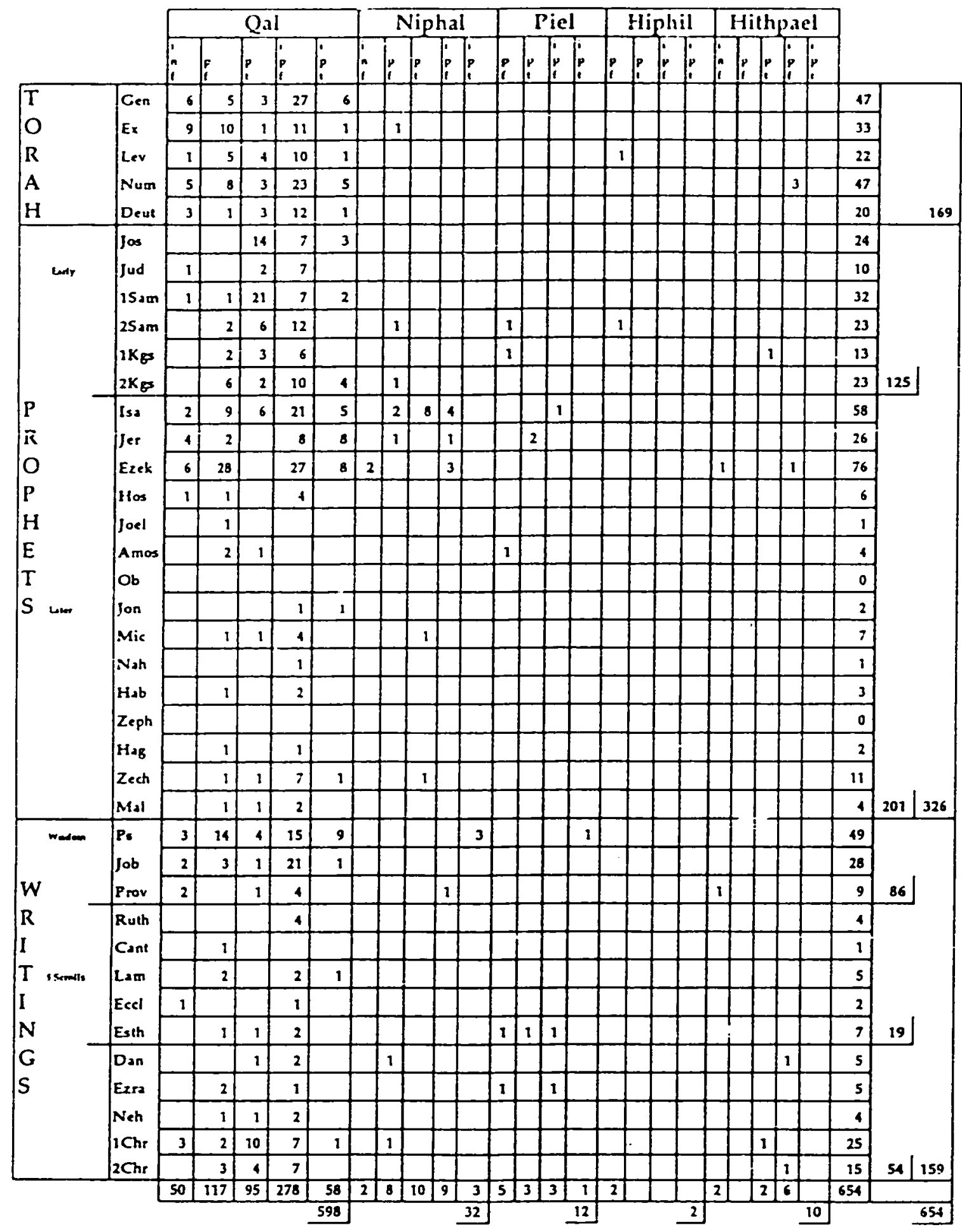

Based on: Aoraham Eucn-Shouhdn: A Nre Concordanse of the Old Trutamme. 
Appendix B

\section{LITERARY CONTEXT}

NON-CULTIC CONTEXT (103x)

CULTIC CONTEXT (66x)

Narrative (88x)

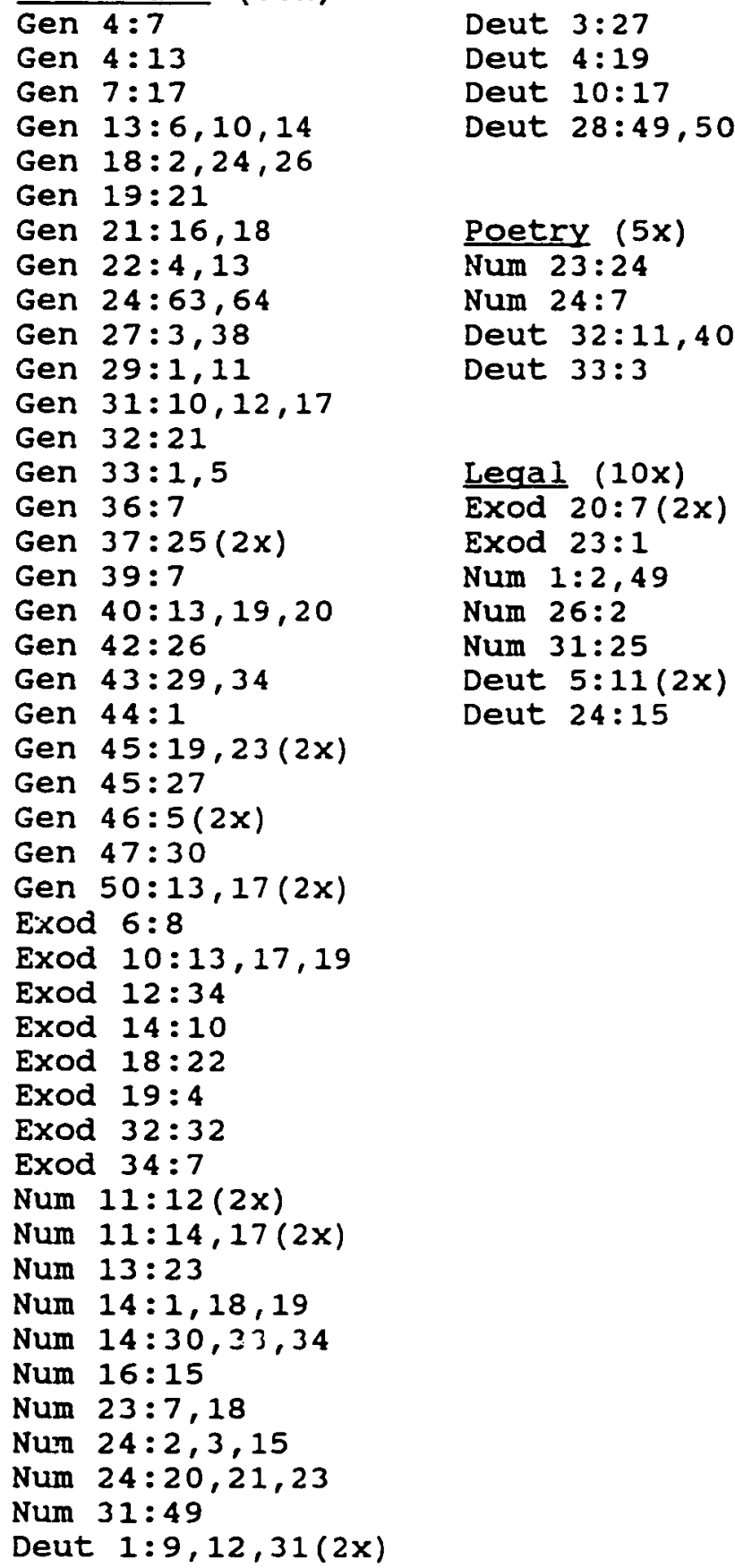

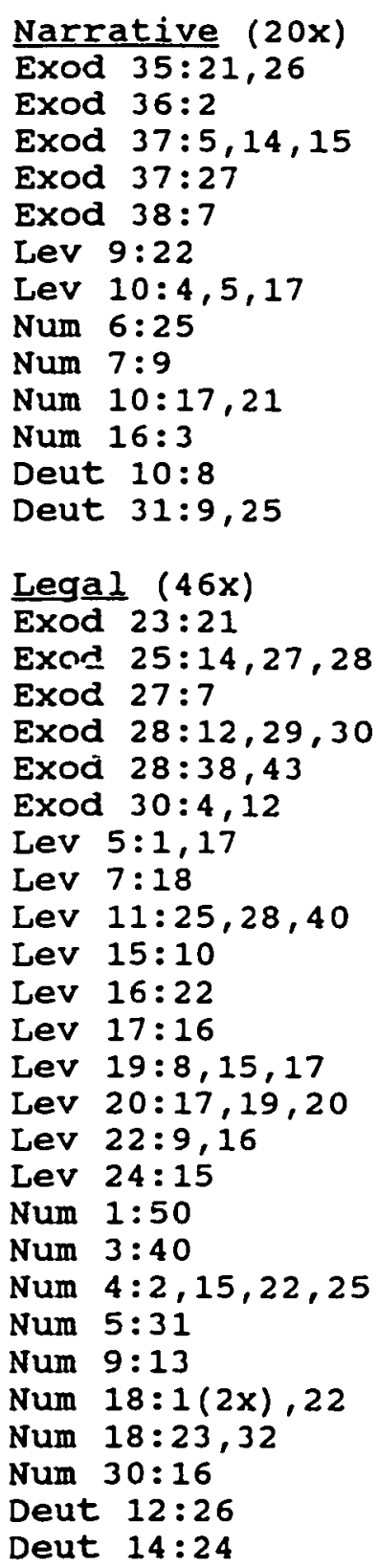

Narrative (20x)

Exod $36: 2$

Exod $37: 5,14,15$

Lev $10: 4,5,17$

Num 6:25

Num $7: 9$

Num $10: 17,21$

Num 16:3

Deut $10: 8$

$31: 9,25$

Exad 25:14,27,28

Exod $27: 7$

Exod 28:12,29,30

Exod $28: 38,43$

Exod $30: 4,12$

Lev 15:10

Lev 16:22

Lev $17: 16$

Lev $20: 17,19,20$

Lev $22: 9,16$

Lev 24:15

Num 1:50

Num $3: 40$

Num $4: 2,15,22,25$

Num $5: 31$

m $9: 13$

Num $18: 1(2 x), 22$

Num $30: 16$

Deut 14:24 
311

Appendix C

PENTATEUCHAL USE: SUBJECT--man (135x)

LITERAL OBJECTS
$\begin{aligned} & (42 \times) \\ & \text { Persons }(6 x) \\ & \text { Gen } 21: 18 \\ & \text { Gen } 31: 17 \\ & \text { Gen } 45: 19 \\ & \text { Gen } 46: 5 \\ & \text { Num } 11: 12 \\ & \text { Deut } 1: 31\end{aligned}$

Animals ( $1 x)$

Num 16:15

Heapons/tools (1x)

Gen $27: 3$

Food $(5 x)$

Gen $42: 26$

Gen $43: 34$

Gen $44: 1$

Exod $12: 34$

Num $13: 23$

Other (gen) ( $8 x$ )

Gen $47: 30$

METAPHORIC

$(92 x)$

Soul (1x)

Deut 24:15

Voice $(4 \mathrm{x})$

Gen 21:16

Gen $27: 38$

Gen 29:11

Num 14:1

Eyes $(18 x)$

Gen 13:10,14

Gen 18:2

Gen $22: 4,13$

Gen $24: 63,64$

Gen $31: 10,12$

Gen $33: 1,5$

Gen $37: 25$

Gen 39:7

Gen 43:29

Exod 14:10

Num 24:2

Deut $3: 27$

Deut $4: 19$

Gen $50: 13$

Lev $10: 4,5$

Lev $11: 25,28,40$

Head ( $8 x$ )

Exod 30:12

Num $1: 2,48$

Num $4: 2$

Num $4: 22$

Num 26:2

(21x)

Exod $25: 14,27,28$

Exod $27: 7$

Exod $30: 4$

Exod $37: 5,14,15$

Num $31: 25,49$

Hand (1x)

Lev $9: 22$

Exod $37: 27$

Exod $38: 7$

Num $1: 50$

Num $4: 15,25$

Num 7:9

Num $10: 17,21$

Deut $10: 8$

Deut 12:26

Deut 14:24

Deut $31: 9,25$

Feet $(1 \mathrm{x})$

Gen 29:1

OBJECTS

other obj (3x)

Num $3: 40$

Num $16: 3$

Deut 33:3

Persons $(10 x)$

Gen 32:21

Gen $40: 13,19,20$

Exod 18:22

Lev 19:15

Num $11: 12,14$

Deut 1:9

Deut 28:50

Name of God (4x)

Exod 20:7 (2x)

Deut 5:11 (2x)

Responsibility

(2x)

Num 11:17(2x)

Sin/wrongdoings (27x)

Gen $4: 13$

Gen $50: 17(2 x)$

Exod 10:17

LeV $5: 1,18$

Lev $7: 18$

Lev $10: 17$

Lev $17: 16$

Lev $19: 8,17$

Lev $20: 17,19,20$

Lev $22: 9,16$

Lev $24: 15$

Num $5: 31$

Num $9: 13$

Num $14: 33,34$

Num $18: 1(2 \mathrm{x})$

False report (1x) Num $18: 22,23,32$

Exod 23:1

Num $30: 16$

Parable (7x)

Num 23:7,18

Names/judgments (6x)

Exod 28:12,29

Num $24: 3,15,20$

Exod 28:30,38, 43

Deut 1:12 


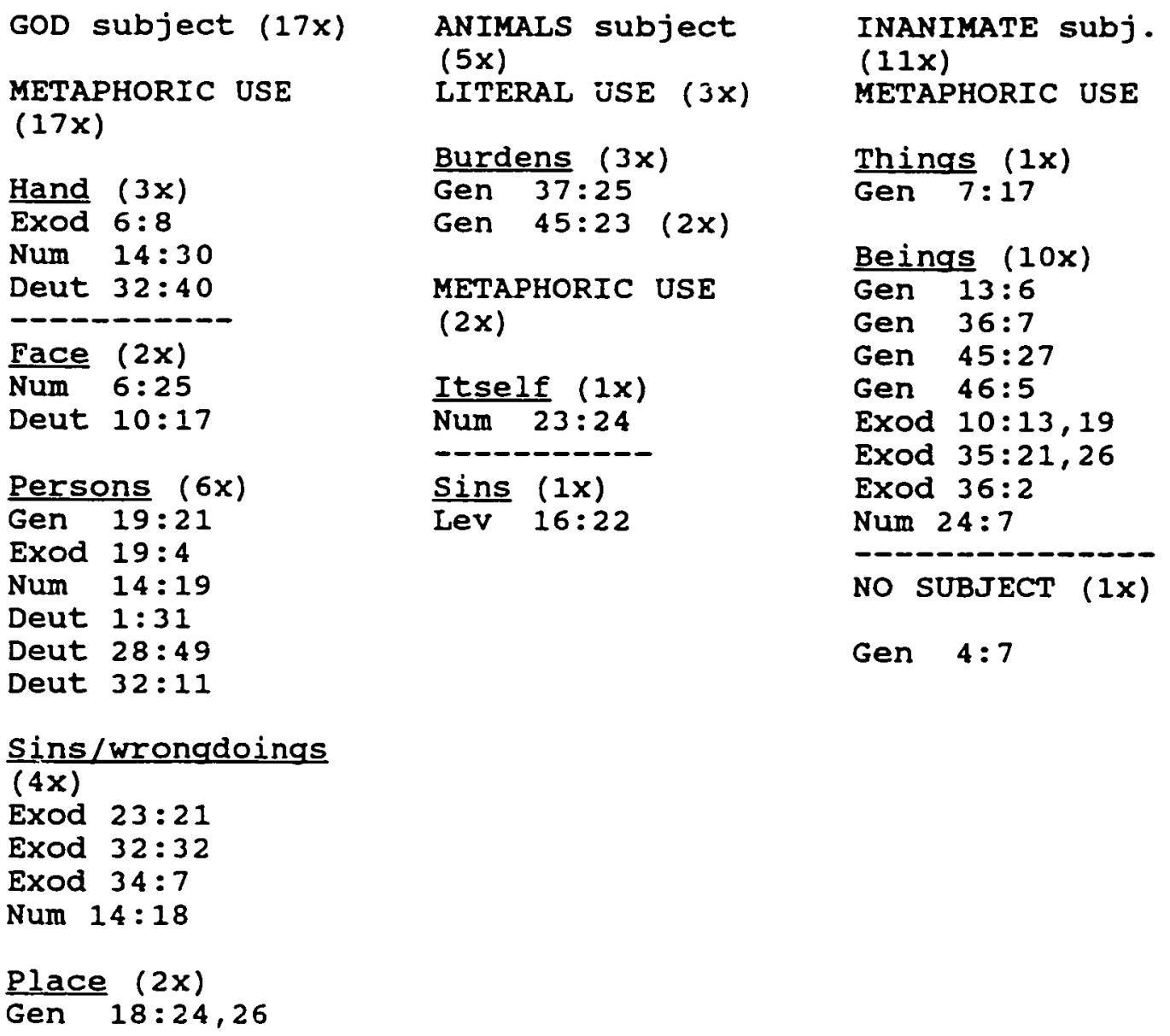


Append ix D

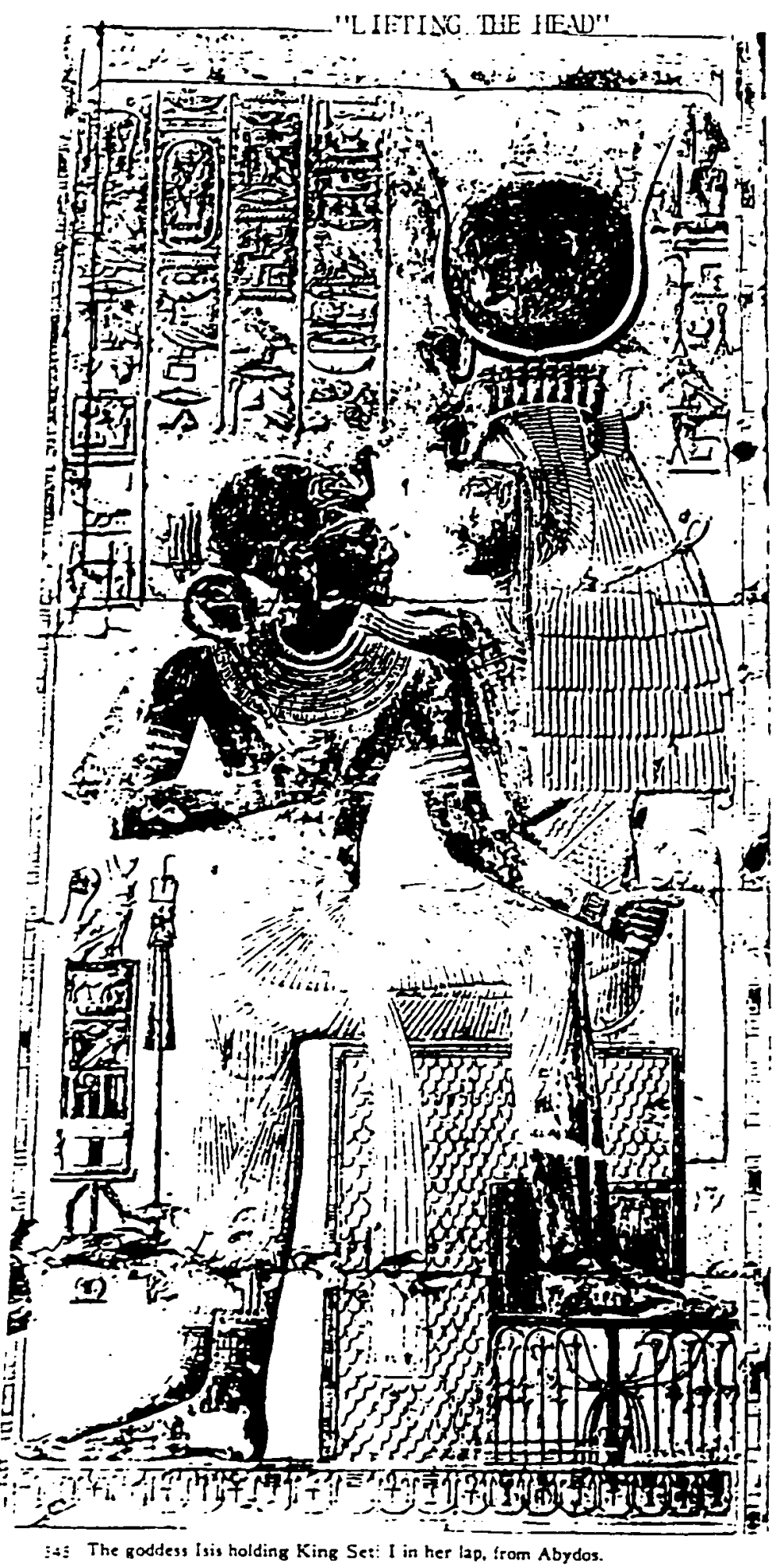


BIBLIOGRAPHY

Reproduced with permission of the copyright owner. Further reproduction prohibited without permission. 


\section{BIBLIOGRAPHY}

Aalders, Gerhard $\mathrm{Ch}$. Genesis. vol. 2. Bible students Commentary. Translated by William Heynen. Grand Rapids: Zondervan Publishing House, 1981.

Ackroyd, Peter R., and Barnabas Lindard, eds. Words and Meaning. Cambridge: At the University Press, 1968 .

Aistleitner, Joseph. Wörterbuch der Ugaritischen Sprache. Berlin: Akademie-Verlag, 1965.

Amsler, Samuel. "M $p$ qūm aufstehen" Theologisches Handwörterbuch zum Alten Testament. Edited by $E$. Jenni and C. Westermann, Munich: Chr. Kaiser Verlag, 1971. 2:635-41.

André, Gunnel. Determinining the Destiny. Lulid, Sweden: C. W. K. Gleerup, 1980 .

Andreasen, Milian L. The Sanctuary Service. Washington, DC: Review and Herald Publishing Association, 1947 .

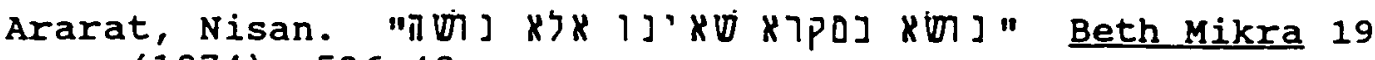
(1974): 536-48.

Arndt, William F., and F. Wilbur Gingrich. A GreekEnglish Lexicon of the New Testament and Other Early Christian Literature. 4 th edition. Chicago: The University of Chicago Press, 1952.

Aufrecht, Walter E. and John Coolidge Hurd. A Synoptic Concordance of Aramaic Inscriptions, according to Herbert Donner and Wolfgang Roellig. Missoula: Scholars Press, 1975.

Balentine, Samuel E. The Hidden God. Oxford: Oxford University Press, 1983.

Barr, James. Comparative Philology and the Text of the old Testament. Oxford: Oxford University Press, 1968 . 
Barr, James. The Semantics of Biblical Language. Oxford: Oxford University Press, 1961.

Bartlett, John R. "The Use of the Word WX 7 as a Title in the old Testament." Vetus Testamentum 19 (1969):110 .

Bauer, Hans, and Pontus Leander. Historische Grammatik der Hebräischen Sprache des Alten Testaments. Hildesheim: Georg Olms Verlagsbuchhandlung, 1962 .

Baumgartner, Walter, et al., eds. Hebräisches und Aramäisches Lexicon zum Alten Testament. 3rd edition. 4 vols. Leiden: E. J. Brill, 1967-90.

Baumann, A. "J kwl." Theologisches wörterbuch zum Alten Testament. Edited by G. Johannes Botterweck, Helmer Ringgren and Heinz-Josef Fabry, Stuttgart: Verlag $W$. Koh lhammer GMBH, 1984. 4:91-95.

Beyse, Karl-Martin. "ל Wio I māšal I." Theoloqisches Wörterbuch zum Alten Testament. Edited by $G$. Johannes Botterweck, Helmer Ringgren and Heinz-Josef Fabry. Stuttgart: Verlag W. Kohlhammer GMBH, 1986. 5:69-72.

Biblia Hebraica Stuttgartensia. Stuttgart: Deutsche Bibelgesellschaft, 1984 .

Biga, Maria Giovanna, and Lucio Milano. Testi Amministrativi: Assegnazioni di Tessuti. Archivi Reali di Ebla IV. Rome: Missione Archeologica Italiana in Siria, 1984 .

Blake, Frank R. A Resurvey of Hebrew Tenses. Roma: Pontificium Institutum Biblicum, 1951.

Blass, Friedrich, and Albert Debrunner. A Greek Grammar of the New Testament. Translated by Robert Funk. Chicago: The University of Chiaago Press, 1961.

Blau, Joshua. On Pseudo-Corrections in Some semitic Larquages. Jerusalem: The Israel Academy of Sciences and Humanities, 1970.

Borland, James E. Christ in the Uld Testament. Chicago: Moody Press, 1978 .

Botterweck, G. Johannes, Helmer Ringgren, et al., eds. Theologisches wörterbuch zur. Alten Testament.

stuttgart: Verlag W. Kohlhammer GMBH, 1970-. 
Brinkman, John A., Miguel Civil, Ignace J. Gelb, A. Leo Oppenheim, and Erica Reiner, eds. The Assyrian Dictionary. Chicago: The Oriental Institute, 1956-.

Brockelmann, Karl. Grundriss der vergleichenden Grammatik der semitischen Sprachen, vol. 1. Hildesheim: Georg Olms Verlagsbuchhandlung: 1961.

Brockelmann, Karl. Lexicon Syriacum. Hildesheim: Georg Olms Verlagsbuchhandlung, 1966.

Brown, Francis, Samuel R. Driver, and Charles A. Briggs, eds. The New Brown, Driver, and Briggs Hebrew and English Lexicon of the old Testament. Grand Rapids: Baker Book House, 1981.

Brown, Francis, Samuel R. Driver, and Charles A. Briggs, eds. A Hebrew and English Lexicon of the Old

Testament. Oxford: At the Clarendon Press, 1907.

Buber, Martin and Franz Rosenziveig. Die Schrift und ihre Verdeutschung. Berlin: Im Schocken Verlag, 1936.

Budd, Philip J. Numbers. Word Bible Commentary. Waco: Word Books, Publishers, 1984.

Buhl, Frants, ed. Gesenius' Handwörterbuch über das Alte Testament. BerIin: Springer Verlag, (1915) 1949.

Burney, Charles F. Notes on the Hebrew Text of the Books of Kings. oxford: At the clarendon Press, 1903.

Caird, George B. The Lanquage and Imagery of the Bible. Philadelphia: The Westminster Press, 1980.

Calberini, oliviera. "Considerazioni sul nāśs ${ }^{\supset}$ ebraico, il naši biltim babilonese e il nāša assiro." Bibbia e oriente 21 (1979):273-81.

"Evoluzione della funzione del nāśs": il libro dei Numeri." Bibbia e oriente 20 (1978): 123-33. 
Carson, D. A. Exegetical Fallacies. Grand Rapids: Baker Book House, 1985.

Castellino, G. R. "Genesis iv 7." Vetus Testamentum 10 $(1960)$ : 442-45.

Cate, Robert L. old Testament Roots for New Testament Faith. Nashville, TN: Broadman Press, 1982.

Childs, Brevard S. Exodus. Philadelphia: Westminster Press, 1974.

Childs, Brevard s. Introduction to the old Testament as scripture. Philadelphia: Fortress Press, 1979.

Childs, Brevard $s$. Review of The Semantics of Biblical Lanquage by James Barr. Journal of Biblical Literature 80/4 (1961):374-77.

Christiansen, Duane L. "Two stanzas of a Hymn in Deuteronomy 33." Biblica 65 (1984):382-89.

Cole, Robert A. Exodus. Downers Grove: InterVarsity Press, 1977.

Collins, John J. "The Meaning of Sacrifice: A Contrast of Methods." Biblical Research 22 (1977):19-34.

Complete concordance to the Bible. New York: Thomas Nelson Publishers, 1983.

Concordance of the Bible in the Moffatt Translation. London: Hodder and Stoughton, 1950.

Concordance to the Good News Bible. Edited by David Robinson. Swindon: Bible Societies, 1983.

Cross, Frank M. and David Noel Freedman. "The Blessing of Moses." Journal of Biblical Literature 67 (1948): 191-210.

Crown, Alan D. "Aposiopesis in the Old Testament." AbrNahrain 4 (1963-64):96-111.

Dahood, Mitchell. "Ebla, Ugarit, and the Bible." In Giovanni Pettinato. The Archives of Ebla. Garden City, NY: Doubleday and Company, 1981.

Daube, David. Sin, Ignorance and Forgiveness in the Bible. London: Liberal Jewish Synagogue, 1961. 
David, Martin. "Zabal (Gen. xxx 20)." Vetus Testamentum 1 (1951):59-60.

Davidson, Benjamin. The Analytical Hebrew and Chaldee Lexicon. Grand Rapids: Zondervan, 1982 .

Davies, Benjamin, ed. Student's Hebrew Lexicon. Grand Rapids: Kregel Publications, 1957.

Davies, Douglas. "An Interpretation of Sacrifice in Leviticus." Zeitschrift der alttestamentlichen Wissenschaft $89(1977): 387-99$.

de Boer, Pieter A. H. "An Inquiry into the Meaning of the Term māśs $\bar{a}^{\prime}$." Oudtestamentische studien. Edited by Pieter A. H. de Boer, 5:197-214. Leiden: E. J. Brill, 1948 .

de Jong, Pieter. "Divine and Human Forgiveness: An Investigation into the Biblical Data about God's and Man's Forgiveness and the Relation between Them, Followed by a Comparison of the Biblical Data and Some of the Systematic and Ethical Approaches to the Problem." Ph.D. dissertation, Union Theological Seminary in the City of New York, 1951.

de Vaulx, J. Les Nombres. Paris: Libraire Lecoffre J. Gabalda et Cie Editeurs, 1972 .

De Meyer, Freddy. "Buber's Translation of the Bible." Louvain studies 7/3 (1979):212-18.

Delitzsch, Friedrich. Assyrisches Handwörterbuch. Leipzig: I. C. Hinrichs'sche Buchhandlung, 1896.

Dentan, Robert $c$. "The Literary Affinities of Exodus XXXIV 6f." Vetus Testamentum 13 (1963):34-51.

Dhorme, Edouard P. "L'emploi métaphorique des noms de parties du corps en hébreu et en akkadien." Revue Biblique 29-32 (1920-23): 466-506; 374-99, 517-40; 215-33, 489-517; 185-212.

Diehm, Werner. "Das Problem von if in Althebräischen und die kanaanäische Lautverschiebung." Zeitschrift des Deutschen Morgengesellschaftes 124 (1974):221-52.

diez Macho, Alejandro. Neophyti 1. Vols. 1-5. MadridBarcelona: Consejo Superior de investigaciones Cientifices, 1970-. 
Dillmann, August. Genesis Critically and Exegetically Expounded. Vol. 2. Translated by Wm. B. Stevenson. Edinburgh: T. and T. Clark, 1897.

Dillon, George L. Introduction Contemporary Linguistic Semantics. Englewood Cliffs, NJ: Prentice-Hall, 1977 .

Dohmen, Christoph. "Zur Bedeutung und Verwendung von hebräischen ע. " Biblische Notizen 16 (1981):7-10.

Donner, Herbert, and Wolfgang Röllig. Kanaanäische und Aramäische Inschriften. 3 vols. Wiesbaden: ctto Harrassowitz, 1966.

Doukhan, Jacques. "L'hébreu en vie." Thesis for Docteur ès Lettres hébraiques. University of Strasbourg, 1573 .

Driver, Godfrey R. Aramaic Documents. Oxford: At the Clarendon Press, 1957.

. "Birds in the old Testament." Palestine Exploration Quarterly 86 (1955):5-20; 129-40.

"Once Again: Birds in the Bible."

Palestine Exploration Quarterly 90 (1958):56-58.

- "Studies in the Vocabulary of the old

Testament." Journal of Theological studies 33

(1931):38-47; and 34 (1932):375-85.

Driver, Samuel R. A critical \& Exegetical Commentary on Deuteronomy. International Critical Commentary. Edinburgh: T. and T. Clark, 1951.

Durham, John I. Exodus. Word Bible Commentary. Waco, TX: Word Book Publishers, 1987.

Dyrness, William. Themes in old Testament Theology. Downers Grove: InterVarsity Press, 1979.

Ehrlich, Arnold B. Randglossen zur hebräischen Bibel. Vols. 1-7. Hildesheim: Georg olms

Verlagsbuchhandlung, (1908) 1968.

Eichrodt, walther. Theology of the old Testament. 2 vols. Translated by J.A. Baker. Philadelphia: Westminster Press, $1961 \& 1967$.

Eisenbeis, Walter. Die Wurzel $51 \mathrm{~m}$ im Alten Testament. Berlin: Walter de Gruyter \& Co., 1969. 
Eising, H. "T)l zākar." Theological Dictionary of the old Testament. Translated by David E. Green. Edited by G. Johannes Botterweck and Helmer Ringgren. Grand Rapids: Wm. B. Eerdmans Publishing Co., 1980. $4: 64-82$.

Ellison, John w., compiler. Nelson's Complete Concordance of the Revised standard Version Bible. New York: Thomas Nelson and Sons, 1957.

Emerson, James G., Jr. The Dynamics of Forgiveness. Philadelphia: Westminster Press, 1964 .

Encyclopedia Judaica. New York: Macmillan Company, 1971.

Even-Shoshan, Avraham. A New Concordance of the old Testament. Jerusalem: "Kiryat Sefer" Publishing House, Ltd. , 1985.

Ewert, David. From Ancient Tablets to Modern Translations. Grand Rapids: Zondervan Publishing House, 1983.

Feliks, Jehuda. "Vultures." Encyclopedia Judaica. Jerusalem: Kefer Publishing House, Ltd., 1972. $16: 232-33$.

Fishbane, Michael. "Form and Reformulation of the Biblical Priestly Blessing." Journal of the American oriental Society $103 / 1$ (1983):115-21.

Fitzgerald, Aloysius. "MTNDBYM in 10S." Catholic Biblical Quarterly 36 (1974):495-502.

Fitzmyer, Joseph A. The Aramaic Inscriptions of Sefire. Rome: Pontifical Biblical Institute, 1967.

Floristán, Casiano and Christian Duquoc, eds. Forgiveness. Edinburgh: T. and T. Clark, 1986.

Fox, Everett. Now These Are the Names. New York: Schocken Books, 1986.

Frazer, James G. The Golden Bough. New York: The Macmillan Company, 1940.

Freedman, David Noel. "The Aaronic Benediction (Numbers $6: 24-26)$." In No Famine in the Land: Studies in Honor of John L. McKenzie, Edited by James $w$. Flanagan and Arita Weisbrod Robinson, 35-48. Missoula: Scholars Press, 1975. 
Freedman, David Noel. "God, Compassionate and Gracious." Western Watch 6 (1955):6-24.

$$
\text { , and B. E. Willoughby. "Kim nāsā'." }
$$

Theol'ogisches wörterbuch zum Alten Testament. Edited by G. Johannes Botterweck, Helmer Ringgren and HeinzJosef Fabry. Stuttgart: Verlag W. Kohlhammer GMBH, 1986. $5: 626-43$.

Fretheim, Terence E. The Suffering of God. Philadelphia: Fortress Press, 1.984 .

Fries, Heinrich. Handbuch Theologischer Grundbegriffe. Munich: Kösel-Verlag, 1963.

Frost, stanley B. "Daniel." Interpreter's Bible Dictionary. Edited by George A. Buttrick. Nashville: Abingdon Press, 1962. 1:761-68.

Fuerst, Julius. A Hebrew and Chaldee Lexicon to the old Testament. Translated by Samue! Davidson. London: Williams \& Norgate, 1867.

Gaster, Theodore H. Myth, Legend, and custom in the old Testament. New York: Harper \& Row Publishers, 1969 .

Gehman, Henry S. "The 'Burden' of the Prophets." The Jewish Quarterly Review 31 (1940):107-121.

Gerleman, Gillis. Essays on Biblical Theology. Minnesota: Augsburg Publishing House, 1981.

"הO) nsh pi. versuchen." Theologisches Handwörterbuch zum Alten Testament. Edited by Ernst Jenni and Claus Westermann. Munich: Chr. Kaiser Verlag, 1971. 2:69-71.

- Studien zur alttestamentlichen Theologie. Heidelberg: Verlag Lambert Schneider, 1980.

Gese, Hartmut. "Die Sühne." Beiträge zur Evangelischen Theologie 73 (1977):85-106.

Gesenius, Guilielmi. Thesaurus Philologicus Criticus Linguae Hebraeae et Chaldaeae Veteris Testamenti. Lipsiae: Sumtibus Typisque Fr. Chr. Guil. Vogelii, 1835 . 
Gesenius' Hebrew Grammar. Edited by E. Kautzsch. 2d edition revised by A. E. Cowley. Oxford: Clarendon press, 1980.

Gesenius's Hebrew and Chaldee Lexicon to the old Testament. Translated by Samuel P. Tregelles. New York: John Wiley \& Sons, 1905.

Gibson, Arthur. Biblical Semantic Logic. New York: St. Martin's Press, 1981.

Gibson, John C. L. Textbook of Syrian Semitic Inscriptions. Vol. 2. Oxford: At the clarendon Press, 1975 .

Giesen, Georg. Die Wurzel šbc 'schwören.' Eine semasiologische studie zum Eid im Alten Testament. Bonner Biblische Beiträge, 56. Bonn: P. Hanstein, 1981 .

Gispen, Willem H. Exodus. Translated by Ed. van der Maas. Grand Rapids: Zondervan Publishing House, 1982 .

Gladson, Jerry A. "The Enigma of 'Azazel' in Leviticus 16." M.A. thesis, Vanderbilt University, 1973.

Göbel, Christa. "'Denn bei dir ist Vergebung. . . .' slh im Alten Testament." Theologische Versuche 8 (1977): 21-33.

Goodrick, Edward W., and John Kohlenberger III. The NIV Complete Concordance. Grand Rapids: Zondervan Publishing Mouse, 1981.

Gordon, Cyrus H. Ugaritic Textibook. Kome: Fontiricai Biblical Institute, 1965.

Gottstein, Moshe H. "Dים (Gen 23:6). V' Vetus Testamentum 3 (1953):298-99.

Gottwald, Norman K. The Hebrew Bible. A Socio-Literary Introduction. Philadelphia: Fortress Press, 1985.

Goulder, Michael D. The Psalms of the Sons of Korah. Journal for the Study of the old Testament Supplement Series 20. Sheffield: JSOT Press, 1982.

Grabbe, Lester I. "The Scapegoat Tradition: A StLdy in Early Jewish Interpretation." Journal for the Study of Judaism $48 / 2$ (1987): 152-67. 
Gray, George B. A Critical \& Exegetical Commentary on Numbers. International Critical Commentary. Edinburgh: T. and T. Clark, 1956.

Gray, John. I and II Kings. Philadelphia: Westminster Press, 1963.

Greenberg, Moshe. Ezekiel 1-20. Anchor Bible. Vol. 22. New York: Doubleday \& Co., 1983.

Grelot, Pierre. Sens crétien de l'Ancien Testament. Paris: Desclée et Cie, Éditeurs, 1962.

Gruber, Mayer I. "The Many Faces of Hebrew ' lift up the face'." Zeitschrift der alttestamentlichen Wissenschaft $95 / 2$ (1983):252-60.

Gunkel, Herrmann. Genesis. Göttingen: Vendenhoek und Ruprecht, 1969.

Gunneweg, Antonius H. J. "Schuld ohne Vergebung?" Evangelische Theologie 36 (1976):2-14.

Harkavy, Alexander. Students' Hebrew and Chaldee Dictionary to the old Testament. New York: Hebrew Publishing Co., 1914 .

Harrison, Roland K. Leviticus. Downers Grove, IL: InterVarsity Press, 1980.

Hartdegen, Stephen J., ed. Nelsons Complete Concordance of the New American Bible. Toronto: G. Welch Co., 1977 .

Hasel, Gerhard F. "Studies in Biblical Atonement, I: Continual Sacrifice, Defilement//Cleansing and sanctuary." In The Sanctuary and the Atonement. Edited by Arnold V. Wallenkampf and W. Richard Lesher, 87-133. Washington, D.C.: Review and Herald Publishing Association, 1981.

Hausmann, J. "Ilo sālah." Theologisches wörterbuch zum Alten Testament. Ėdited by G. Johannes Botterweck, Helmer Ringgren and Heinz-Josef Fabry. Stuttgart:

Verlag $w$. Kohlhammer GMBH, 1986. 5:859-67.

Hayes, John H. "Restitution, Forgiveness, and the Victim in OT Law." Trinity University Studies in Religion $11(1982): 1-23$. 
Hazard, Marshall C. A Complete Concordance to the American Standard Version of the Holy Bible. New York: Thomas Nelson and Sons, 1922 .

Hedby, Karl. "Handpåläggningsrit och försoningsoffer." Svensk Exegetisk Årsbok $49(1984): 58-65$.

Heinisch, Paul. Theology of the old Testament. Translated by William Heidt. Collegeville, MN: Liturgical Press, 1950.

Held, Moshe. "The Root $z B L / S B L$ in Akkadian, Ugaritic and Biblical Hebrew." Journal of the American Oriental Society $88(1968): 90-96$.

Helfmeyer, Franz Josef. "הOJ nissāh." Theologisches wörterbuch zum Alten Testament. Edited by $G$. Johannes Botterweck, Helmer Ringgren and Heinz-Josef Fabry, stuttgart: Verlag W. Kohlhammer GMBH, 1986. 5:47388 .

Herner, Sven. "Sühne und Vergebung in Israel." Bulletin de la Societé Royale des lattres de Lund, 19411942, 47-121. Lund: C. W. K. Gleerups Förlag, 1942.

Herrmann, Johannes. Die Idee der sühne in Alten Testament. Eine Untersuchung über Gebrauch und Bedeutsung des Wortes Kipper. Leipzig: J.C. Hinrichs'sche Buchhandlung, 1905.

Hills, Sidney Oscar. "A Semantic and Conceptual study of the Root RPR in the Hebrew old Testament with Special Reference to the Accadian Kuppuru." Ph.D. dissertation, Johns Hopkins University, Baltimore, MD, 1954 .

Hoffmeier, James $K$. "Some Egyptian Motifs Related to Warfare and Enemies and Their old Testament counterparts." The Ancient World 6/1-4 (1983):53-70.

Holladay, William L. A Concise Hebrew and Aramaic Lexicon of the old Testament. Grand Rapids: Wm. B. Eerdmans Publishing Company, 1971.

Horn, Siegfried, ed. Seventh-day Adventist Bible Dictionary. Washington, DC: Review and Herald Publishing Association, 1960.

Horst, Friedrich. Gottes Recht. Munich: Chr. Kaiser Verlag, 1961. 
Hossfeld, Frank-Lothar. "Versöhnung und Sühne." Bibel und Kirche 41 (1986):54-60.

Hossfeld, Frank-Lothar, and E. Reuter. "Xib] II, nāšă II." Theologisches wörterbuch zum Alten Testament. Edited by G. Johannes Botterweck, Helmer Ringgren and Heinz-Josef Fabry, Stuttgart: Verlag $W$. Kohlhammer GMBH, 1986. 5:658-63.

Hummel, Horace D. "Justification in the old Testament." Concord Journal 9 (1983):9-17.

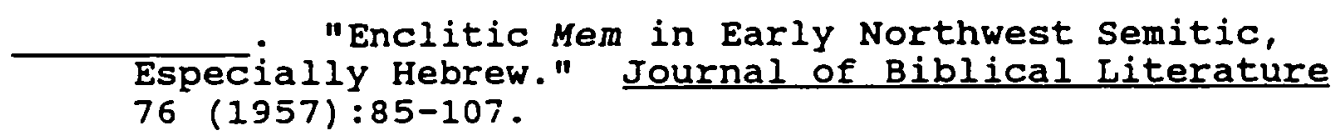

Hyde, William T. "The Hebrew Word kaphar and Its freek and English Equivalents in Relation to the Doctrine of Atonement." B.D. thesis, Seventh-day Adventist Theological Seminary, Takoma Park, 1958.

Janowski, Bernd. "Auslösung des verwirkten Lebens." Zeitschrift für Theologie und Kirche 79/1 (1982): 2559 .

. "Sühne als Heilsgeschehen." Theologische Literaturzeitung 106 (1981): 779 .

- Sühne als Heilsgeschehen. Neukirchen-Vluyn: Neukirchener Verlag, 1982.

Jastrow, Mareus. A Dictionary of the Targumime the Talmud Babli and Yerushalmi, and the Midrashic Literature. New York: Judaica Press, 1975.

Jean, Charles-F., and Jacob Hoftijser. Dictionnaire des Inscriptions Sémitique de l'ouest. Leiden: E. J. Brill, 1965.

Jenni, Ernst and Claus Westermann, eds. Theologisches Handwörterbuch zum Alten Testament. 2 vols. Munich: Chr. Kaiser Verlag, 1971-76.

Jirku, Anton. Altorientalischer Kommentar zum alten Testament. Hildesheim: Verlag Dr. H. A. Gerstenberg, 1972 .

Joüon, Paul P. Grammaire de 1'hébreu biblique. Rome: Institut Biblique Pontifical, 1947. 
Kaiser, walter $c$. "Kin lift, carry, take." Theological Wordbook of the oid Testament. Edited by R. L. Harris, Gleason L. Archer, and Bruce $\mathrm{K}$. Waltke. Chicago: Moody Press, 1981. 600-601.

Kaye, Michael. "Forgiveness." The Hibbert Journal 29 $(1930): 202-18$.

Keil, Carl F., and Franz Delitzsch. Biblical Commentary on the old Testament. Vols. 1-3. Grand Rapids: Wm. B. Eerdmans Publishing Company, 1949.

Kellems, Jesse R. Studies in the Forgiveness of Sins. New York: George H. Doran Co., 1926.

Kent, Homer A. "The Forgiveness of sins in the OT." The Expositor 21 (1921):365-86.

Kidner, Derek. "Sacrifice-Metaphors and Meaning." Tyndale Bulletin 33 (1982):119-36.

Kittel, Gerhard, and Friedrich Gerhard, eds. Theological Dictionary of the New Testament. 10 vols. Grand Rapids: Eerdmans, 1964-76

Kiuchi, N. The Purification offering in the Priestly Literature. Journal for the study of the old Testament Supplement Series, 56. Sheffield: JSOT Press, 1987.

Kleinig, John w. "On Eagles' wing. An Exegetical Study of Exodus 19:2-8." Lutheran Theological Journal 21/1 $(1987): 18-27$.

Klopfenstein, Martin A. Die Lüge nach dem Alten Testament. Zürich: Gotthelf Verlag, 1964.

Knierim, Rolf. Die Hauptbegriffe für Sünde im Alten Testament. Gütersloh: Gütersloher Verlagshaus, 1967 .

Koch, Klaus. "Gibt es ein Vergeltungsdogma im Alten Testament?" Zeitschrift für Theologie und Kirche 52 $(1955): 1-42$.

- "Sühne und Sündenvergebung um die Wende von der exilischen zur nachexilischen zeit." Evangelische Theologie 26 (1966):217-39.

ed. Um das Prinzip der Vergeltung in Religion und Recht des Alten Testaments. Darmstadt: Wissenschaftliche Buchgesellschaft, 1972. 
Koch, Robert. "La remission et la confession des péchés selon 1'Ancien Testament." Studia Moralia 10 (1972): 219-47.

Il Peccato nel Vecchio Testamento. Rome:

Edizioni Paoline, 1973.

Koehler, Ludwig and Walter Baumgartner. Lexicon in Veteris Testamenti Libros. Leiden: E. J. Brill, 1958 .

Köhler, Ludwig. old Testament Theology. Translated by A. S. Todd. Philadelphia: Westminster Press, 1957. - "Zabal-tragen, ertragen." Theologische Zeitschrift 5 (1949):395.

König, Eduard. Hebräisches und aramäisches wörterbuch zum Alten Testament. Leipzig: Dieterich'sche Verlagsbuchhandlung, 1936.

Kopf, Lothar. "Arabische Etymologien und Parallelen zum Bibelwörterbuch." Vetus Testamentum 8 (1958):161215.

Korpel, Marjo c. A. "The Poetic structure of the Priestly Blessing." Journal for the study of the old Testament 45 (1989):3-13.

Kraeling, Emil. The Brooklyn Museum Aramaic Papyri. New Haven: Yale University Press, 1353.

Ktba Ddytyga 'tyga. [Syriac Bible]. New York: United Bible Societies, 1979.

Kutscher, Edward Y. "Contemporary Studies in NorthWestern Semitic." Journal of Semitic Studies 10/1 (1965) : 35-41.

Kuzlivelil, Matthew $V$. "Reconciliation in the old Testament." Biblebhashyam 9 (1983):168-178.

Lampe, Geoffrey W. H. A Patristic Greek Lexicon. Oxford: At the Clarendon press, 1961.

Lang, Bernhard. "J kippær." Theologisches Wörterbuch zum Alten Testament. Edited by $G$. Johannes Botterweck, Helmer Ringgren, and Heinz-Josef Fabry. stuttgart: Verlag $W$. Kohihammer, 1984. 4:303-18. 
LaSor, William S., David A. Hubbard, and Frederic W. Bush. old Testament Survey. Grand Rapids: Wm. B. Eerdmans Publishing Company, 1982.

Leroy, Herbert. Zur Vergebung der sünden. stuttgart: $\mathrm{K}$. B. W. Verlag, 1974 .

Levy, Jacoi. Wörterbuch über die Talmudim und Midrashim. Darmstadt: Wissenschaftliche Buchgesellschaft, 1963.

Liddell, Henry G., and Robert scott, compilers. A Greek English Lexicon. 9 th edition, revised by Henry $S$. Jones. Oxford: At the clarendon Press, 1978.

Limbeck, Meinrad. "Die Sühne der Sünden." Bibel und Kirche 33 (1978):15-19.

Lindenberger, James M. The Aramaic Proverbs of Ahiqar. Baltimore: The John Hopkins University Press, 1983.

Lipinski, Edward. "Urim and Thummim." Vetus Testamentum $20(1970): 495-96$.

Lorenz, Oswald. "Altorientalischer Hintergrund sowie inner-und nachbiblische Entwicklung des aaronitischen Segens (Num 6,24-26)." Ugaritforschungen 10 (1978) : 115-19.

Lyonnet, Stanislas. Sin, Redemption and Sacrifice. Rome: Biblical Institute, 1970.

Maly, Eugene H. "Sin and Forgiveness in the Scriptures." In sin, Salvation, and the Spirit. Edited by Daniel Durken, 40-48. Collegeville, MN: Liturgical Press, 1979.

Mangatt, George. "Forgiveness." Biblebhashyam 8/1 (1982): 42-53.

Mannuci, Valerio. "Peccato, perdono e reconciliazione nell' antico testamento." Bibbia e oriente 25 (1983): 87-96.

Marcus, David. A Manual of Akkadian. New York: University Press of America, 1978.

Margain, Jean. Essais de sémantique sur l'hébreu ancien. Paris: Libraire orientaliste Paul Geuthner S. A., 1976 . 
Martens, Elmer A. God's Design. Grand Rapids: Baker Book House, 1981.

Mayes, Andrew D. H. Deuteronomy. New Century Bible. London: Oliphants, 1979.

McCarthy, Dennis J. Treaty and Covenant. Rome: Biblical Institute Press, 1978.

Mccree, Walter $T$. "The Covenant Meal in the old Testament." Journal of Biblical Literature 45 (1926): 120-28.

McFall, Leslie. The Enigma of the Hebrew Verbal System. Sheffield: Almond Press, 1982.

Mckane, William. "Massā’ in Jeremiah 23:33-40." In Prophecy. Edited by J. A. Emerton, 35-54. New York: Walter Gruyter, 1980.

Médebielle, A. "Expiation." Dictionaire de la Bible. Supplement. Paris: Libraire Letonzey et Ané, 1938. $7: 1-262$.

Menes, Abram. Die vorexilischen Gesetze Israels. Zeitschrift der alttestamentlichen wissenschaft, Beihefte 50. Giessen: Verlag vom Alfred Töpelmann, 1928 .

Milgrom, Jacob. Ieviticus 1-16. Anchor Bible. New York: Doubleday, 1991.

"Priestly Terminology and the political and Social structure of Pre-Monarchic Israel." Jewish Quarterly Review 68 (1978):65-81.

- "The Literary Structure of Numbers 8:5-22 and the Levitical Kippar." In Perspectives on Language and Text. Edited by Edgar W. Conrad and Edward G. Newing. Winona Lake: Eisenbrauns, 1987.

- Studies in Levitical Terminology. Vol. 1. London: University of California Press, 1970. $(1976): 333-37$.

Miller, Edward F. The Influence of Gesenius on Hebrew Lexicography. New York: Columbia University Press, 1927 . 
Miller, Patrick D. "The Blessing of God." Interpretation $29(1975): 240-51$.

Moberly, R. W. L. At the Mountain of God. JSOT Supplement Series, 22. 1983.

Mowinckel, Sigmund. Psalmenstudien. Vol. 1. Amsterdam: P. Schippers, 1966.

Montgomery, J.A. Critical and Exegetical commentary on the Book of Daniel. International Critical Commentary. Vol. 1. Edinburgh: T. and T. Clark, 1950 .

Morro, William Charles. "Forgiveness." In The International standard Bible Encyclopedia. Edited by James Orr. Grand Rapids: Wm. B. Eerdmans, 1939. $2: 1132-35$.

Moscati, Sabatino, Anton Spitaler, Edward Ullendorff and Wolfram von Soden. An Introduction to the Comparative Grammar of the Semitic Lancruages. Edited by Sabatino Moscati. Wiesbaden: otto frarrassowitz, 1980 .

Müller, H.-P. "KinD maśsāJ." Theologisches Wörterbuch zum Alten Testament. Edited by $G$. Johannes Botterweck, Helmer Ringgren and Heinz-Josef Fabry. Stuttgart: Verlag $w$. Kohlhammer, 1986. 5:20-25.

. "WKר rōś Ropf." Theologisches Handwörterbuch zum Alten Testament. Edited by Ernst Jenni and Claus Westermann. Munich: Chr. Kaiser Verlag, 1976. $2: 701-15$.

Murconen, A. "The Use and Meaning of the Words 1'bäarak and $b^{2} r \bar{a} \underline{k} \bar{a}$ in the old Testament." Vetus Testamentum 9 (1959):158-177.

Neusner, Jacob. The Talmud of the IJand of Israel. Chicago: University of Chicago, 1983.

Niehr, Herbert. "K' zum Alten Testament. Edited by $G$. Johannes Botterweck, H. Ringgren and Heinz-Josef Fabry. Stuttgart: verlag W. Kohlhammer, 1986. 5:647-56.

Noordtzij, Arie. Leviticus. Bible Students Commentary. Translated by R. Togtman. Grand Rapids: Zondervan Publishing House, 2.982 . 
Noordtzij, Arie. Numbers. Bible students Commentary. Translated by Ed. van der Maas. Grand Rapids: Zondervan Fublishing House, 1983.

Noth, Martin. Numbers: A Commentary. old Testament Library. Translated by J.D. Martin. London: SCM Press, 1968.

- Das System der Zwölf Stämme Israels. Darmstadt: Wissenschaftliche Buchgesellschaft, 1966.

Noth, Martin. Das Zweite Buch Mose. Exodus. Alte Testament Deutsch. Neues Göttingen Bibelwerk. Göttingen: Vandenhoeck \& Ruprecht, 1965.

Nötscher, Friedrich. "Das Angesicht Gottes schauen" nach biblischer und babylonischer Auffassung. Darmstadt: wissenschaftliche Buchgesellschaft, 1969.

Nyberg, Henrik S. Hebreisk Grammatik. Stockholm: Almquist \& Wiksell, 1952 .

Oesterley, William O. E., and Theodore H. Robinson. An Introduction to the Books of the old Testament. London: SPCK, 1958 .

Olafsson, Gudmundur. "The Use of Kaphar in the Pentateuch." Termpaper, Andrews University Theological Seminary, 1983.

Olsen, Viggo Norskov. "The Doctrine of Forgiveness in the Light of Biblical Hebrew and Greek Words." M.A. thesis, Seventh-day Adventist Theological Seminary, Takoma Park, 1950.

Ostrup, Jens. Orientalische Höflichkeit. Leipzig: Otto Harrassowitz, 1929.

Oswalt, John. The Book of Isaiah 1-39. New International Commentary on the old Testament. Grand Rapids: Wm. B. Eerdmans Publishing company, 1986.

Parker, Albert R. "Expiation and Propitiation in Relation to the Conciliation Concept of the Atonement." B.D. thesis, Seventh-day Adventist Theological Seminary, Takoma Park, 1955.

Parmelee, Alice. A Guidebook to the Bible. London: University Press, 1954 .

Paton, Margaret. "Can God Forget?" Scottish Journal of Theology 35 (1982):385-402. 
Pedersen, Johannes. Israel: Its Life and Culture. 2 vols. London: oxford University Press, 1926-40.

PEntateuch with Targum onkelos, Haphtaroth and Prayers for the Sabbath and Rashi's Commentary. Deuteronomy. Translated by M. Rosenbaum and A. M. Silbermann. London: Shapiro, Vallentine \& Co., 1946.

Pettinato, Giovanni. The Archives of Ebla. Garden City, NY: Doubleday and Company, 1981.

Phillips, Anthony. Ancient Israel's Criminal Law. Oxford: Basil Blackwell, 1970.

Polzin, Robert. Late Biblical Hebrew: toward a Historical Typology of Biblical Hebrew Prose. Missoula, MT: Scholars Press, 1976.

Pope, Marvin H. "Oaths." The Interpreter's Dictionary of the Bible. Nashville: Abingdon Press, 1962 . 3:57577 .

Porteus, N. W. "Semantics and old Testament Theology." oudtestamentische studien. Edited by Pieter A. H. de Boer. Leiden: E. J. Brill, 1950. 8:1-14.

Pritchard, James B. The Ancient Near East in Pictures. Princeton: Princeton University Press, 1954.

Procksch, otto. Die Genesis. Leipzig: A. Deichertsche Verlagsbuchhandiung, 1913.

- Theologie des Alten Testaments. Gütersloh: C. Bertelsmann Verlag, 1950 .

Quanbeck, Warren A. "Forgiveness." The Interpreters Dictionary of the Bible. Nashville: Abingdon Press, 1962. 2:315-19.

Rahlfs, Alfred, ed. Sentuaginta. Stuttgart: Deutsche Bibel-geselischaft, 1979 .

Raitt, Thomas Marshall. "The Concept of Forgiveness in the Pre-Exilic Prophets in Relation to Its FormHistorical setting." Ph.D. dissertation, Vanderbilt University, 1964.

Reallexicon der Assyriologie. Vol. 1. Berlin: Walter de Gruyter \& Co., 1932. S.v. "Adler."

Redlich, E. Basil. The Forqiveness of Sins. Edinburgh: T. and T. Clark, 1937. 
Reif, C. S. "A Root to Look Up? A Study of the Hebrew nāsā' ${ }^{\prime}$ ayin." Vetus Testamentum Supplement 36 (1985) : 230-44.

Reindl, Joseph. Das Angesicht Gottes im Sprachgebrauch des Alten Testaments. Leipzig: St. Benno-Verlag GMBH, 1970 .

Rendtorff, Rolf. The old Testament. Translated by John Bowden. Philadelphia: Fortress Press, 1986.

Ringgren, Helmer. "נס Jāsāh." Theologisches Wörterbuch zum Alten Testament. Edited by $G$. Johannes Botterweck, Helmer Ringgren and Heinz-Josef Fabry. Stuttgart: Verlag $w$. Kohlhammer, 1984. 4:272-77. - "Some Remarks on the Language of Religion." Temenos 2 (1969):103-111. $2(1966): 98-111$.

Robertson, A. T. A Grammar of the Greek New Testament in the Light of Historical Research. Nashville: Broadman Press, 1934 .

Robertson, Edward. "The Urim and Thummim; What Were They?" Vetus Testamentum 14 (1964):67-74.

Robinson, Edward. Hebrew and English Lexicon of the old Testament. Cambridge: Houghton, Mifflin \& Co., 1882 .

Rodriguez, Angel M. Substitution in the Hebrew Cultus. Andrews University Seminary Doctoral Dissertation series. Vol. 3. Berrien Springs, MI: Andrews University Press, 1979.

Rowley, Harold H. Worship in Ancient Israel: Its Forms and Meaning. London: SPCK, 1967.

Ruprecht, Erich. "Oל gIt retten." Theologisches Handwörterbuch zum Aiten Testaments. Edited by Ernst Jenni and Claus Westermann. Munich: Chr. Kaiser Verlag, 1971. 2:420-27.

Sabottka, Liudger. "Is 30, 27-30: Ein Übersetzungsvorschlag." Biblische zeitschrift 12 (1968):241-243. 
Sakenfeld, Katharine D. The Meaning of Hesed in the Hebrew Bible: A New Inquiry. Missoula, MT: Scholars Press, 1978 .

- "The Problem of Divine Forgiveness in Numbers 14." Catholic Biblical Quarterly 37 (1975):317-30.

Salmonia: or Days of Fly Fishing, by an "Angler". Republished by Humphrey Davy. New York: Freshet Press, 1970.

Sanda, Albert. Die Bücher der Könige. Münster in Westfalen: Aschendorffsche Verlagsbuchhandlung, 1911.

Sansom, M. C. "Laying-on of Hands in the old Testament." Expository Times 94 (1983):323-26.

Sasson, Victor. "An Unrecognized "Smoke-signal" in Isaiah XXX 27." Vetus Testamentum 33 (1983):90-95.

Sawyer, John F. A. "Root-Meanings in Hebrew." Journal of Semitic studies 12 (1967):37-50.

Scharbert, Josef. "Vergebung." Handbuch Theologischer Grundbegriffe. Edited by Heinrich Fries. Munich: Kösel-Verlag, 1963. 740-4‥

Schenker, Adrian. Versöhnung und Sühne. Freiburg: Verlag Schweizerisches Katholisches Bibelwerk, 1981.

- "Wege gewaltfreier Konfliktlösung im Alten

Testament." Bibel und Kirche 37 (1982):44-50.

Schmitt, Elmer William John. "Sin and Forgiveness in the old Testament." Ph.D. dissertation, Drew Theological Seminary, 1943.

Schökel, Alonso. "illo māhāh." Theologisches Wörterbuch zum Alten Testament. "Edited by G. Johannes Botterweck, Helmer Ringgren, and Heinz-Josef Fabry. stuttgart: Verlag $\mathrm{W}$. Kohlhammer, 1984. 4:804-8.

Schottroff, Willy. "TJ zkr gedenken." Theologisches Handwörterbuch zum Alten Testament. Edited by Ernst Jenni and Claus Westermann, Munich: Chr. Kajser Verlag, 1971. 1:507-18.

Schwager, Raymond. Brauchen wir einen sündenbock? Gewalt und Erlösung in den biblischen Schriften. Munich: Kösel-Verlag, 1978. 
Schwarz, Günther. "Begünstige nicht. . ?" Lev 19:15b." Biblische Zeitschrift 19 (1975): 1100 .

Scott, R. B. Young. " $K$ ' $W$ I = Cumulus clouds." Zeitschrift der alttestamentlichen Wissenschaft 64 (1952):25.

Seeligmann, I. I. "A Psalm from Pre-Regal Times." Vetus Testamentum 14 (1964):75-92.

- "Zur Terminologie für das Gerichts-verfahren im Wortschatz des biblischen Hebräisch." Hebräische Wortforschung. Festschrift zum 80 . Geburtstag von W. Baumgartner. Vetus Testamentum Supplement, 16:25178. Leiden: E. J. Brill, 1967.

Seow, Choon L. A Grammar for Biblical Hebrew. Nashville: Abingdon Press, 1987.

Seybold, Klaus. Der aaronische Segen. Studien zu Numeri $6,22-27$. Neukirchen-Vluyn: Neukirchener Verlag, 1977 .

Silva, Moisés. Biblical Words and Their Meaning. Grand Rapids: Academie Books, 1983.

Simian-Yofre, H. "O' zum Alten Testament. Edited by Heinz-Josef Fabry and Helmer Ringgren. Stuttgart: Verlag $w$. Kohlhammer, 1989. 6:629-59.

Skinner, John. A Critical and Exegetical Commentary on Genesis. International Critical Commentary. Edinburgh: T. and T. Clark, 1951.

Smith, Jessie Payne, ed. A Compendious Syriac Dictionary. oxford: At the clarendon Press, 1957.

Smith, R. Payne. Thesaurus Syriacus. Oxford: At the Clarendon Press, 1879.

Smith, William R. Lectures on the Religion of the Semites. Jerusalem: KTAV Publishing House, Inc., 1969 .

Snaith, Norman H., ed. Leviticus and Numbers. Century Bible. London: Thomas Nelson and Sons, 1967.

Sollberger, Edmond. Archivi Reali di Ebla VIII. Rome: Missione Arceologica Italiana di siria, 1986. 
Speer, Jack Atkeson. The Living Bible Concordance. Poolesville, MD: Poolesville Presbyterian Church, 1973 .

Speiser, Ephraim A. "Background and Function of the Biblical nāśs." Catholic Biblical Quarterly 25 (1963) : 111-17.

"Census and Ritual Expiation in Mari and
Israei." Bulletin of the American School of
oriental Research $149(1958): 17-25$.

Speiser, Ephraim A. Genesis. Anchor Bible. Vol. 1. Garden City, NY: Doubleday and Co., 1964.

Spence, Henry D. M. and J. Exell, eds. Pulpit Commentary. Vol. 3. Grand Rapids: Wm. B. Eerdmans Publishing Company, 1977.

Stähli, Hans-Peter. "017 ram, hoch sein." Theologisches Handwörterbuch zum Alten Testament. Edited by Ernst Jenni and Claus Westermann. Munich: Chr. Kaiser Verlag, 1976. 2:753-61.

Stamm, Johann J. "DreiBig Jahre Dekalogforschung." Theologische Rundschau 27/4 (1961): 288-290.

- Erlösen und Vergeben im Alten Testament.

Bern: A. Francke, A.-G. Verlag, 1940.

- "Ilo slh vergeben." Theologisches

Handwörterbuch zum Alten Testament. Edited by Ernst Jenni and Claus Westermann. Munich: Chr. Kaisar Verlag, 1971. 2:150-160.

Staples, W. E. "The Third Commandment." Journal of Biblical Literature 58 (1939):325-29.

Steinmetzer, Franz X. "Bemerkungen zu den babylonischen Grenzsteinurkunden." orientalische Literat:1rzeitung 7,8 (1920): 151-154.

Stendebach, Franz Josef. "I' Cajin." Theologisches wörterbuch zum Alten Testament. Edited by $G$. Johannes Botterweck, Helmer Ringgren, and Heinz-josef Fabry. Stuttgart: Verlag $\mathrm{W}$. Kohlhammer, 1986. 5: 31-48.

Stoebe, Hans Joachim. Gott, sei mir sïnder gnädig. Neukirchen: Neukirchener Verlag, 1958. 
Stoebe, Hans Joachim. "KY $r \mathrm{P}^{2}$ heilen" Theologisches Handwörterbuch zum Alten Testament. Edited by Ernst Jenni and Claus Westermann. Munich: Chr. Kaiser Verlag, 1976. 2:803-809.

Stolz, Fritz. "XiD nś aufheben, tragen." Theologisches Handwörterbuch zum Alten Testament. Edited by Ernst Jenni and Claus Westermann. Munich: Chr. Kaiser Verlag, 1976. 2:109-17.

Strong, James. The Exhaustive Concordance of the Bible. Nashville: Abingdon Press, 1986.

Sturdy, John. Numbers. Cambridge: Cambridge University Press, 1976.

Sung, Chong-Hyon. "Sündenvergebung Jesu bei den Synoptikern und seine Voraussetzungen im Alten Testament und frühen Judentum." Inaugural Dissertation zur Erlangung der Doktorwirde der Evangelisch Theologischen Fakultät an der EberhardKarls-Universität, Tübingen, 1984 .

Swete, Henry Barclay. The Forgiveness of Sins. London: MacMilian \& Co., Ltd.. 1916.

Talmon, Shemaryahu. "Martin Buber's Ways of Interpreting the Bible." Journal of Jewish Studies 27 (1976): 195-209.

Tawil, Hayim. "Azazel, The Prince of the Steepe: A Comparative Study." Zeitschrift der alttestamentIichen Wissenschaft 92 (1980):45-59.

Taylor, Vincent. "Forgiveness." Expository Times 51 $(1939): 16-21$.

Telfer, William. The Forgiveness of Sins. Philadelphia: Muhlenberg Press, 1960.

Thierry, G. J. "Notes on Hebrew Grammar and Etymology." oudtestamentische studien. Edited by Pieter A. H. deBoer. Leiden: E. J. Brill, 1951. 9:1-17.

Thomas, David W., ed. Hebrew and Semitic studies. Oxford: Clarendon Press, 1963.

Thomas, Robert I., ed. New American Standard Exhaustive Concordance of the Bible. Nashville: Holman Bible Publishers, 1981. 
Thyen, Hartwig. Studien zur sündenvergebung. Göttingen: Vandenhoek \& Ruprecht, 1970.

Traductiun oecuménique de la Bible. Paris: Alliance biblique universelle-Le Cerf, 1982 .

Tsevat, Matitiahu. "Alalakhiana.' Hebrew Union College Annual 29 (1958):109-134.

Uliman, stephen. Semantics. An Introduction to the science of Meaning. Oxford: Basil Blackwell, 1967.

van der Ploeg, Johannes. "Les chefs du peuple d'Israel et leurs titres." Revue Biblique 57 (1950):40-61.

van der Woude, Adam S. "पणं šēm, Name." Theologisches Handwörterbuch zum Alten Testament. Edited by Errist Jenni and Claus Westermann. Munich: Chr. Kaiser Verlag, 1976. 2:935-63.

Veijola, Timo. "Das dritte Gebot (Namenverbot) im Lichte einer ägyptischer Parallele." Zeitschrift für die alttestamentliche Wissenschaft 103 (1991):1-17,

Vogt, Ernst. Lexicon Linquae Aramaicae Veteris Testamenti. Roma: Pontificium Institutum Biblicum, 1971.

von Rad, Gerhard. Genesis: A Commentary. Translated by $J$. H. Marks. Philadelphia: Westminster Press, 1961.

"7R'D in the old Testament." Theological Dictionary of the New Testament. Edited by Gerhard Kittel. Translated by G. W. Bromiley. Grand Rapids: Wm. B. Eerdmans, 1964. 1:76-80.

- oid restament Theology. 2 vols. Translated by D. M. G. Stalker. New York: Harper \& Row Publishers, $1962 \& 1965$.

- The Problem of the Hexateuch and other

Essays. Translated by E. W. Trueman Dicken. London: 1966.

von Soden, Wolfram. Akkadisches Handwörterbuch. Wiesbaden: Otto Harrassowitz, 1965-.

Vriezen, Theodore c. "Sündenvergebung." Die Religion in Geschichte und Gegenwart. Edited by Kurt Galiing, 6:507-11. Tübingen: J. C. B. Mohr, 1962 . 
Wainwright, Geoffrey. Eucharist and Eschatology. London: Epworth Press, 1971.

Waltke, Bruce K., and M. O'Connor. An Introduction to Biblical Hebrew Syntax. Winona Lake, IN: Eisenbrauns, 1990.

Waring, Dawn E. "The Nature of Yahweh's Relationship with His People: A Literary Analysis of Exodus 32-34." Ph.D. dissertation, Fuller Theological Seminary, 1985 .

Wehmeier, Gerhard. "II "Ih hinaufgehen." Theologisches Handwörterbuch zum Alten Testament. Edited by Ernst Jenni and Claus Westermann. Munich: Chr. Kaiser Verlag, 1976. 2:272-90.

Weidner, Ernst. "Hof- und Harems-Erlasse assyrischer Könige." Archiv für orientforschung 17 (1954-6): 268-79.

Weinfeld, Moshe. "I' I berit," Theological Dictionary of the old Testament. Translated by John T. Willis. Edited by G. Johanne:s Botterweck and Helmer Ringgren. Grand Rapids: Wm. B. Eerdmans Publishing Co., 1975. $2: 253-279$. $(1975): 120-128$.

Wells, Paul R. James Barr and the Bible. Phillipsburg, NJ: Presbyterian \& Reformed Publishing Company, 1980 .

Wenham, Gordon I. The Book of Leviticus. The New International Commentary of the old Testament. Grand Rapids: Wm. B. Eerdmans Publishing Company, 1979.

- Genesis 1-15. Word Bible Commentary. Waco: Word Book, Publishers, 1987.

Numbers. Downers Grove: Intervarsity Press,

Westermann, Claus. Genesis. Vols. 1-3. Neukirchen-Vluyn: Neukirchener Verlag, 1974.

Whitaker, Richard E. A Concordance of the Ugaritic Literature. Cambridge, MA: Harvard University Press, 1972. 
Whybray, R. N. Thanksgiving for a Liberated Prophet. Sheffield: Journal for the study of the old Testament Suppiement Series, 4, 1978.

Wigram, George V. The Enqlishman's Hebrew and Chaldee Concordance of the old Testament. 5 th edition. Grand Rapids, MI: Zondervan Publishing House, 1970.

Winer, Georg Benedict, ed. Lexicon Manuale Hebraicum et Chaldaicum in Veteris Testamenti Libros. Lipsiae: Apud Fridericum Fleischer, 1828.

Wood, John G. Bible Animals. New York: Charles Scribner and Company, 1870 .

Woodring, Hoyt $C$. "Grace under the Mosaic Covenant." Ph.D. dissertation, Dallas Theological Seminary, 1956.

Wright, David P. The Disposal of Impurity. Society of Biblical Literature Dissertation Series, 101. Atlanta: Scholars Press, 1987.

Wright, G. Ernest. "Divine Name and Divine Nature (Exod 33:12-34:9)." Perspective 12 (1971):177-85.

- God Who Acts: Biblical Theology as Recital. London: SCM Press, 1952.

Wright, William. Lectures on the Cornparative Grammar of the Semitic Lanquages. Cambridge: At the University Press, 1890.

Zimmerli, Walther. "Die Eigenart der prophetischen Rede des Ezechiel." Zeitschrift für die alttestamentliche Wissenschaft 66 (1954):1-26.

- Ezechiel, vol. 1. Neukirchen-vluyn: Neukirchener Verlag, 1969.

Zorell, Franciscus. Lexicon Hebraicum et Aramaicum Veteris Testamenti. Roma: Sumtibus Pontificii Instituti Biblici, 1946. 